\title{
PELOS OLHOS DE ALICE: ANCESTRALIDADE AFRO-AMERÍNDIA, AMBIENTALISMO E FORMAÇÃO Uma tese de ficção autobiográfica
}

Tese entregue como parte dos requisitos para obtenção do título de Doutora em Educação pelo programa de pós-graduação em Educação da Faculdade de Educação da Universidade de São Paulo, com orientação do Prof. Dr. Marcos Ferreira-Santos.

Universidade de São Paulo

Faculdade de Educação

São Paulo/2016 


\begin{abstract}
AUTORIZO A REPRODUÇÃO E DIVULGAÇÃO TOTAL OU PARCIAL DESTE TRABALHO, POR QUALQUER MEIO CONVENCIONAL OU ELETRÔNICO, PARA FINS DE ESTUDO E PESQUISA, DESDE QUE CITADA A FONTE.
\end{abstract}

Catalogação na Publicação

Serviço de Biblioteca e Documentação

Faculdade de Educação da Universidade de São Paulo

92

C129p
Caffagni, Carla Wanessa do A.

"Pelos olhos de Alice": ancestralidade afroameríndia, ambientalismo e formação - uma tese de ficção autobiográfica" / Carla Wanessa do A. Caffagni; orientação Marcos Ferreira-Santos. São Paulo: s. n., 2016.

351 p.; ils.

Tese (Doutorado - Programa de Pós-Graduação em Educação.

Área de Concentração: Cultura, Organização e Educação) - Faculdade de Educação da Universidade de São Paulo.

1. Autobiografia 2. Ficção-Gênero 3. Formação do individuo 4. Educação 5. Hermenêutica 6. Mitos I. Ferreira-Santos, Marcos, orient.. 


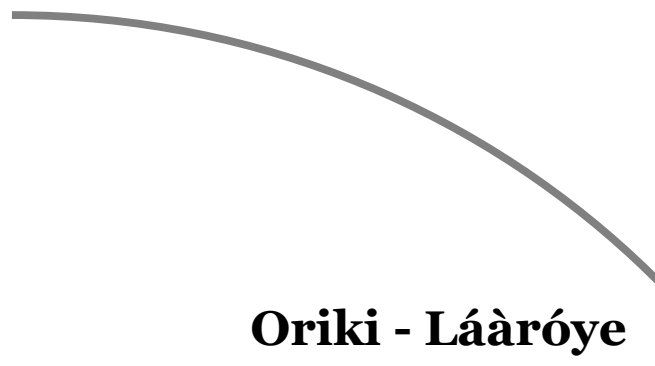

\author{
Láàróye \\ Adíjààle takété \\ Bàbá òríta \\ A fi'bi díre, a fire díbi \\ Má se mi o \\ Má so béèni mi di béèko \\ Má so béèko mi di béèni \\ Ojòwú okùnrín \\ Láàróye
}

Láàróye
É aquele que começa a briga e depois se afasta
O ancião das encruzilhadas Aquele que recompensa o bem com o mal e o mal com o bem

Não me faça mal

Não troque meu sim por não Não troque meu não por sim.

Homem ciumento.

Láàróye 


\section{... sobre as estrelas no céu}

Agradecimentos

Alice, lampeira menina, tem os olhos cheios de brilhos. Nem sempre se pode ver os brilhos de Alice, mas sabe-se que estão lá.

Alice é feita de muitas gentes, muitas situações, muitos momentos... Alice é feita de felicidade, tristeza, mentiras e realidades. São muitas as realidades de Alice, como são muitos os seus afetos.

Nos brilhos de Alice cabem as luzes refletidas de seus meninos, que nem sempre são meninos, mas sempre são de luz. Alice não seria Alice se não fosse tanta luz e por isso, todo dia Alice espera pela noite para observar no céu as luzes que as fazem ser quem é.

Alice ama as estrelas e não sobreviveria se não fosse seu céu imensamente estrelado... cada estrela tem um cheiro, uma lembrança, uma história, um amor, uma cantiga, um afago, um olhar, mas Alice não gosta de dar nome às estrelas porque sabe que estrelas são especiais demais para serem lembradas só pelo nome. Assim, Alice agradece à todas as estrelas de seu céu e dança para que elas estejam sempre ali, mesmo que só em pensamento.

Viva as estrelas de Alice, porque as estrelas de Alice sabem que pertencem ao precioso céu que só Alice consegue tocar... 
Dedico este trabalho a todos os meninos de luz que alumiam os caminhos... em especial, aos meus filhos João Pedro e Jahmall

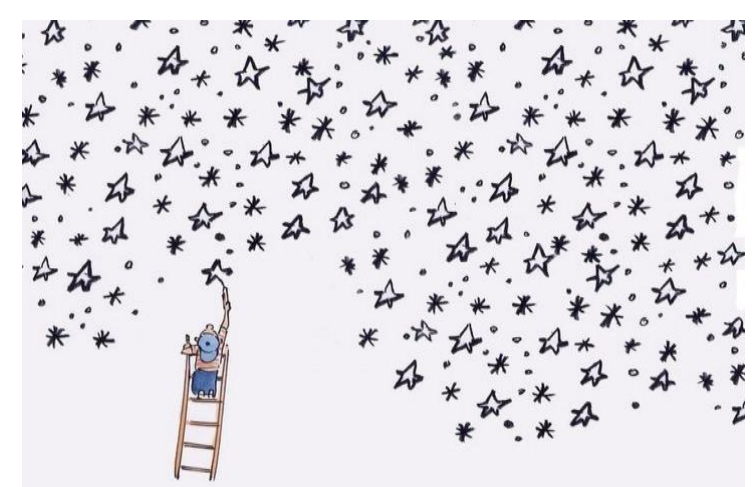




\section{RESUMO}

CAFFAGNI, Carla Wanessa. "Pelos Olhos de Alice: ancestralidade afro-ameríndia, ambientalismo e formação - uma tese de ficção autobiográfica”. 351 p. Tese de doutorado. Faculdade de Educação. Universidade de São Paulo. São Paulo, 2016.

Esta pesquisa buscou desenvolver um estudo em antropologia simbólica sobre o processo de autoformação do sujeito a partir da análise de um material de ficção autobiográfica. Este material foi elaborado com base no resgate e registro escrito de memórias da própria autora da pesquisa e teve seu início na escrita do memorial acadêmico, que forneceu elementos propícios para a compreensão do processo de formação de um "eu-aprendiz". A ficção autobiográfica analisada, escrita anteriormente à pesquisa, tem como personagem principal a menina Alice, que vive suas aventuras em narrativas fantásticas, cujo simbolismo propicia uma análise fenomenológica sobre as emoções e experiências que, ao longo da vida, permitiram a formação do sujeito-autor deste trabalho, considerando-o mais do que um produto do meio social ou ambiental, mas um ser em constante formação, fruto também das suas escolhas e de suas próprias leituras do mundo. As experiências vividas e representadas no mundo simbólico de Alice consideram como parte de sua criação o contato com alguns mestres, que por meio da palavra e do convívio orientaram desejos e influenciaram escolhas ao longo da vida da autora. Para compreender a relação entre mestre e aprendiz vivida por Alice, partimos para o resgate de histórias de vida de dois mestres que tiveram papéis decisivos para a autora. Buscamos encontrar na autobiografia ficcional conexões entre estas histórias de vida, por via da mitohermenêutica, tentando entender como estas vidas foram sendo construídas e em que momento estas pessoas passaram a ser mestres e a autora, aprendiz. Uma busca sobre o eu e o outro que se constitui em $\operatorname{mim}$.

Palavras-chaves: autobiografia ficcional; autoformação; histórias de vida, mestre-aprendiz. 


\section{ABSTRACT}

"Through the eyes of Alice: afro-amerindian ancestrality, environmentalism and formation - an autobiographic fiction thesis." 351 p. CAFFAGNI, Carla Wanessa. Doctoral thesis . Faculdade de Educação. Universidade de São Paulo. São Paulo, 2016.

This research aimed to develop an anthropological study about the subject's self-formation process from the analysis of an autobiographical fiction. This material was elaborate based on the very author`s rescue and written record of memories and had its beginning on the writing of an academic memorial, providing favorable elements for the comprehension of the self-learner formation process. The autobiographic fiction analyzed was written before the research, has as its main subject the girl called Alice, that lived her adventures in fantastic narratives, whose symbolism foments an phenomenological analysis in the experiences and emotions that, during life, allowed the formation of this author-subject's work, considering herself more than a social and environmental media, but someone in constant formation, also a result of her choices and her own readings of the world. The experiences lived and represented in Alice`s symbolic world, consider, as part of her creation, the contact with some masters that through orality and acquaintanceship, determined desires and influenced choices along the author's life. To understand the relation between master and apprentice played by Alice, we start from the rescue of life stories of two masters that had decisive parts for the author-subject. We seek to find connections between these life stories in the fictional autobiography, via mitohermeneutics, trying to understand how these lives were being constructed and in what moment these people passed to be masters, and the author, apprentice. A search about the self, and the other that is constituted in me.

Keywords: fictional autobiography ; self-training ; life stories , master-apprentice . 


\section{RESUMEN}

CAFFAGNI, Carla Wanessa. "A través de los ojos de Alice: ancestralidad afro-amerindia, ambientalismo y formación - una tesis de ficción autobiográfica”. 351 p. Tesis de Doctorado. Facultad de Educación. Universidad de São Paulo. São Paulo, 2016.

Esta investigación buscó desarrollar un estudio antropológico sobre el proceso de autoformación del sujeto a partir del análisis de un material de ficción autobiográfico. Este material fue elaborado en base al rescate y registro escrito de memorias de la propia autora de la investigación y tuvo inicio durante la escritura del memorial académico, el cual proveyó los elementos propicios para la comprensión del proceso de formación de un "yo-aprendiz". La ficción autobiográfica analizada, escrita anteriormente a la investigación, tiene como personaje principal a la niña Alice, que vive sus aventuras en narraciones fantásticas, cuyo simbolismo propicia un análisis fenomenológico sobre las emociones y experiencias que, a lo largo de la vida, permitieron la formación del sujeto-autor de este trabajo, considerándolo más que un producto del medio social o ambiental, como un ser en constante formación, fruto también de sus decisiones y de sus propias lecturas del mundo. Las experiencias vividas $\mathrm{y}$ representadas en el mundo simbólico de Alice consideran como parte de su crianza, el contacto con algunos maestros que por medio de la palabra y del ejemplo en la convivencia, orientaron deseos e influenciaron decisiones a lo largo de la vida de la autora. Para comprender la relación entre maestro y aprendiz, vivida por Alice, partimos al rescate de historias de vida de dos maestros que tuvieron papeles decisivos en la vida de la autora. Buscamos encontrar en la autobiografía ficcional conexiones entre estas historias de vida, por vía de la mito-hermenéutica, intentando entender cómo estas vidas fueron siendo construidas y en qué momento estas personas pasaron a ser maestros y la autora, aprendiz. Una búsqueda sobre el yo y el otro que se constituyen en mí.

Palabras clave: autobiografía ficcional; autoformación; historias de vida; maestro-aprendiz. 


\section{SUMÁRIO}

1 - As asas de Alice

$\begin{array}{ll}1.1 \text { - Os meninos de luz } & 17\end{array}$

1.2 - A luz do menino Matheus $\quad 18$

1.3 - A luz do menino Alcides $\quad 19$

1.4 - A origem da luz $\quad 21$

2 - O dragão e a menina Alice 33

2.1 - Sobre as cigarras... $\quad 36$

2.2 - ... E fez-se a luz $\quad 38$

2.3 - Sobre os nosso quintais $\quad 39$

3 - Alice entre o Bem e o Mal 45

3.1 - Deus e o diabo numa terra sem Sol $\quad 46$

3.2 - A religiosidade como desejo de pesquisa $\quad 48$

$3 \cdot 3$ - Não era deus, nem o diabo $\quad 51$

4 - Alice e o mundo atrás do espelho 57

4.1 Um buraco profundo $\quad 59$

5 - Alice e o encontro com as fadas $\quad 65$

5.1 - Sobre as sobras ou sobre as peças $\quad 67$

6 - Alice e o homem sem face $\quad 75$

6.1 - Os caminhos $\quad 77$

7 - O dragão, os sapos e a solidão $\quad 85$

7. 1 Andando sob as sombras $\quad 87$

7.2 - Caixa de paredes brancas $\quad 89$

8 - O Castigo de Alice 97

8.1 - Faz de conta, faz de verdade! 99

8.2 - Quem sou eu? Alice 103

8.3 - O dragão, a sombra do dragão 105 
9 - Alice e as princesas

10 - Alice e o Sátiro

10. 1 - Acendam as luzes!

10. 2 - Os monstros

131

10. 3 - Convite à jornada

11 - Alice na Escola de Bruxas

11. 1 - Pés na estrada

11.2 - O caminho

145

11. 3 - O encontro com os mestres

150

12 - Alice e a BIOMBA

12. 1 - A casa de luz

12.2 - O encontro com os mestres

168

13 - Alice e as festas das luzes

175

13. 1 - Até as luzes se apagarem

177

13.2 - A entrada no labirinto

180

13.3 - O encontro com os mestres

183

14 - O presente de Alice

189

14. 1 - Vida-morte

191

14.2 - A busca por novos

194

14. 3 - O presente de Alice

197

14.4 - Encontro com os mestres

202

15 - Alice nas trevas

209

15.1 - O deserto sem Sol

211

15.2 - O Sol

212

16 - Alice e o velho preto de luz

219

16.1 - A cidade caixa de concreto

221

16. 2 - Vidas secas

227

16. 3 - O mestre preto de luz

230 
17 - Alice e os guerreiros de Aruanda 239

17.1 - O início do fim $\quad 241$

17.2 - O reencontro com a alma $\quad 251$

17.3 - Alice e o guerreiro 254

18 - Alice na batalha final $\quad 269$

\section{Capítulo Final}

1 - Rosa dos ventos - sentidos teóricos fundamentais e intermediários da pesquisa

1.1 - A carta de marear

277

1.2 - O marinheiro e o mar

277

1.3 - Os mestres do mar

281

286 2 - Projeções cartográficas - o método do contorno do 296

2.1 -Memória, imaginação, lembrança e promessa 296

2.2 - Entre mundos

300

3 - A busca pelo self - a jornada pelo mundo inferior 305

3.1 - O primeiro estágio

309

3.2 - O segundo estágio

313

3.3 - O terceiro estágio

316

3.4 - O quarto estágio

321

3.5 - O quinto estágio

327

3.6 - O sexto estágio

332

3.7 - O sétimo estágio

334

4 - Deixa "serei-ar"...

343

Referências bibliográficas 



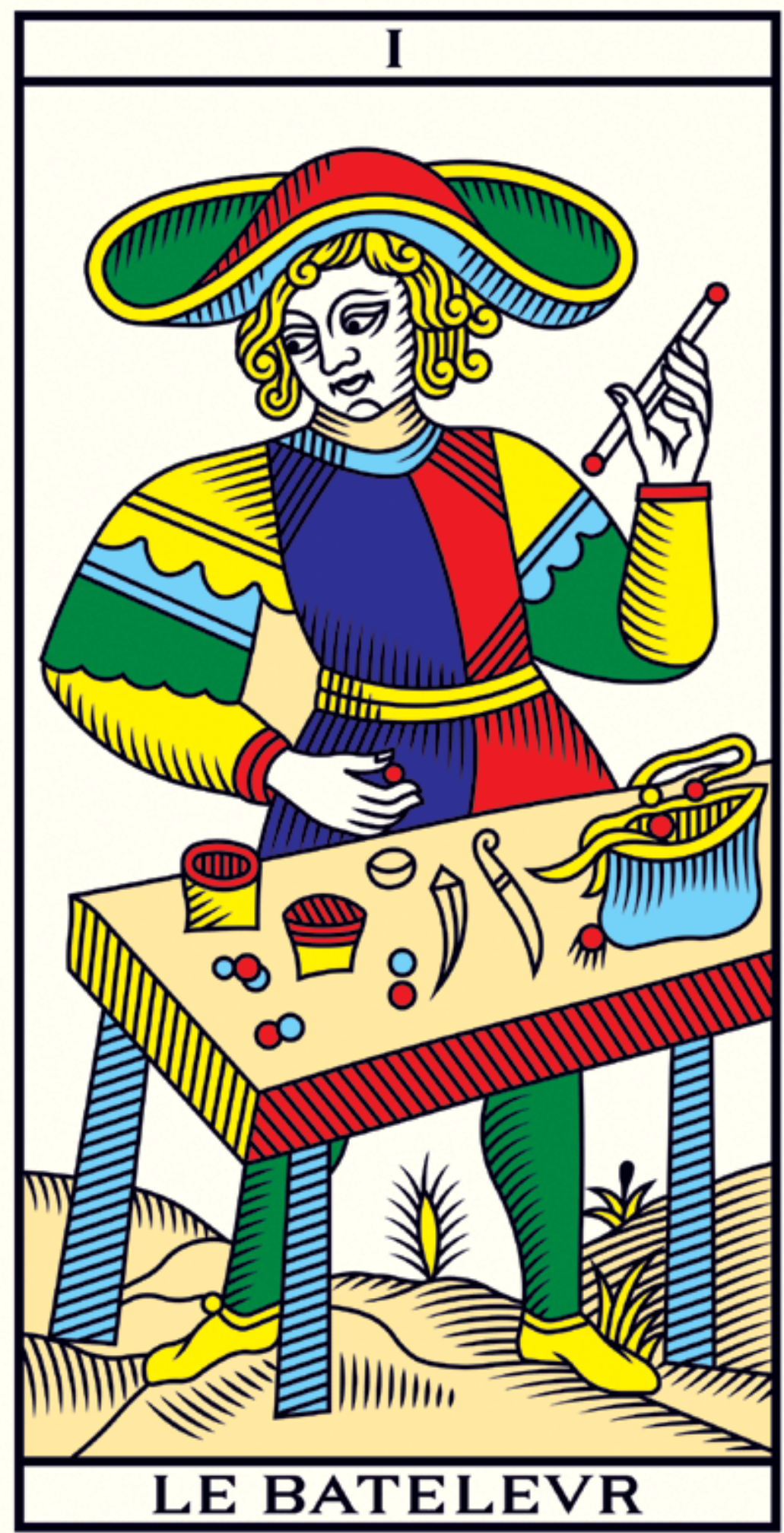




\section{Debaixo d'água}

Arnaldo Antunes

Debaixo d'água tudo era mais bonito

mais azul mais colorido

só faltava respirar

Mas tinha que respirar

Debaixo d'água se formando como um feto

sereno confortável amado completo

sem chão sem teto sem contato com o ar

Debaixo d'água por enquanto sem sorriso e sem pranto sem lamento e sem saber o quanto

esse momento poderia durar

Mas tinha que respirar

Debaixo d'água ficaria para sempre ficaria contente longe de toda gente para sempre

no fundo do mar

Mas tinha que respirar

Debaixo d'água protegido salvo fora de perigo aliviado sem perdão e sem pecado sem fome sem frio sem medo sem vontade de voltar

Mas tinha que respirar

Debaixo d'água tudo era mais bonito

mais azul mais colorido

sófaltava respirar

Mas tinha que respirar

Todo dia

Todo dia, todo dia

Todo dia

Todo dia, todo dia 


\section{1 - As asas de Alice}

Corre Alice. Corre! Alice precisava fugir do dragão. Alice era doce, tinha um olhar meigo e infantil. Alice era uma criança sensível. Tudo para Alice era uma grande descoberta.

Alice andava pelo jardim e descobria flores, cores, perfumes... Alice descobria caminhos, conversava com bichos $e$ ouvia histórias dos meninos de luz.

Havia muitos meninos de luz onde Alice vivia e os meninos contavam para Alice histórias de mundos onde Alice nunca havia estado. Com tantas histórias, com tantos perfumes e tantos caminhos, Alice voava. Alice adorava quando isso acontecia. De repente, cresciam asas em Alice e ela saia voando, vendo o mundo de cima... vendo os rios, as águas, Alice sentia o vento batendo em seu rosto e, apesar de não conseguir voar para muito longe, Alice aproveitava tudo que podia do voo de suas asas mágicas.

O problema das asas de Alice é que elas só apareciam quando Alice estava feliz, não que isto fosse ruim, mas às vezes Alice precisava fugir e, na fuga, Alice fazia força, sonhava, desejava, gritava por suas asas, mas nada acontecia.

Alice vivia num mundo cheio de magia e magia tem da boa e da ruim. No lado escuro do mundo de Alice viviam seres malignos com quem Alice não sabia lidar.

Alice sempre foi de acreditar na bondade de todos... Alice olhava o dragão nos olhos e procurava em toda aquela fúria algum sentimento de amor. Alice sempre achou que o dragão gritava de dor e que sua maldade era só a forma com que ele expressava seu amor. Até hoje, Alice sofre com essa confusão 
entre amor e dor, maldade e cuidado. Nunca sabe distinguir uma coisa da outra.

O dragão vivia na mesma caverna que Alice, mas quase nunca se encontravam. O dragão dormia o dia todo e Alice voava o tempo todo. Quando suas asas desapareciam, Alice, às vezes, caía desajeitada no chão e acordava o dragão. O dragão não suportava nenhum tipo de som, nem de cor, nem de luz e, quando o dragão acordava e via nos olhos de Alice todo aquele oceano de brilho, ele juntava dentro de si toda a sua força $e$ urrava para cima de Alice com tanta força, que saiam labaredas de sua boca. Estas labaredas queimavam $e$ arremessavam Alice contra a parede.

Por vezes, Alice não tinha forças para levantar, chorava até desmaiar. Seu sono a tirava da dor. A única forma que tinha de se livrar de tanta dor era acordar de novo. Alice nunca entendeu porque a botaram em uma caverna com esse dragão, mas não era esta a resposta que buscava. A única coisa que Alice tentava entender era por que o dragão se incomodava tanto com o brilho do seu olhar. 


\section{1 - Os meninos de luz}

...brilha por um breve momento a verdade, sempre ameaçada, de que cada e todo homem, sobre a base de seus próprios sofrimentos e alegrias, constrói para todos.

Albert Camus

Apresento aqui a personagem Alice, que representa em metáfora e alegoria a minha trajetória de vida. Neste primeiro texto, Alice nos conta sobre a importância dos meninos de luz em sua vida, que seriam, na verdade, a representação dos mestres que fui encontrando e escolhendo ao longo da minha trajetória para me guiarem e ensinarem a escolher melhor os meus caminhos.

No texto de Camus, se diz "que cada e todo homem, sobre a base de seus próprios sofrimentos e alegrias, constrói para todos”. Em concordância com a poesia, afirmo que todos que passaram pela minha vida construíram algo e seria assim difícil considerá-los todos mestres. Mestre é alguém especial, responsável pelas passagens e travessias... É aquele que nos ensina a nadar.

Encontrei meus mestres no mar, nas andanças pela vida. Como mestres foram muitos, escolhemos dois deles para contar a história. Essa escolha se deu de forma subjetiva e pessoal, no entanto, em meio às subjetividades, encontrei em Gusdorf uma definição que deu sentido à busca:

“Todo mestre também é, num certo sentido, um mestre artesão que soube primeiro ganhar-se a si mesmo através de uma conquista metódica. A obra fundamental do homem é ele mesmo e as realizações exteriores são apenas confirmações dessa obraprima fundamental que para o homem digno desse nome é a edificação de si mesmo" (2003, p.93). 
Meus mestres foram antes de tudo exemplos de vida. Pessoas que venceram barreiras ignoraram as certezas de destinos comuns e fizeram de sua vida uma história incomum.

Assim, apresento aqui dois dos meninos de luz que iluminaram de forma tão profunda minha vida, que pelas suas mãos e palavras pude aprender a viver de maneira mais plena e madura no mundo e, que acima de tudo, determinaram caminhos. Esses meninos de luz foram e são meus mestres e, nesta primeira parte, vamos conhecer a origem dos pontos de luz... E toda origem vem do ventre.

\section{2 - A luz do menino Matheus}

"Sou Carlos Eduardo Matheus. Matheus com 'th'. Nasci em São Carlos no dia 21 de novembro de 1950, o ano em que o Brasil perdeu a Copa no Maracanã. Meu pai é Haroldo Matheus com ,'h'e minha mãe Eurides Alves Matheus.

O meu pai era vendedor, trabalhou muito tempo nas Casas Pernambucanas, foi subgerente. Viajava muito, mascateava nas viagens para o interior, para as fazendas, vendendo fardos de roupas. Antigamente se vendia muito fardo, tecido de fazer roupa. Não tinha roupa pronta como tem hoje, antes era só fardos, então ele levava aqueles rolos e vendia por metro... tantos metros desse daqui... tantos metros do outro e daí ficava vendendo nas fazendas, sítios e trabalhava nas Casas Pernambucanas. Ele nasceu em Sertãozinho, perto de Ribeirão Preto, e depois veio para Ribeirão Bonito, de Ribeirão Bonito veio para São Carlos, onde conheceu minha mãe. 
A minha mãe foi professora primária e deu aula muito tempo, inclusive em fazenda também. Eu tive oportunidade de ir junto com ela algumas vezes quando ela dava aula na fazenda Santa Rufina, perto de Ibaté. A gente ia de jardineira para lá. Ia até Ibaté, em Ibaté pegava uma charrete e ia até a fazenda, passava a semana inteira na fazenda e ai vinha na sexta-feira embora. Eu ia junto com ela, tinha quatro, cinco anos e eu lembro perfeitamente de tudo.

Meus pais eram muito gente boa, minha mãe e meu pai só viveram para cuidar dos filhos. Eles eram muito dedicados. Meu pai morreu cedo, com 55 anos, mas ele foi sempre assim, um pai muito presente, muito preocupado. Vivia para a família e não tinha outra vida. Minha mãe também. Minha mãe era muito abnegada. Eu sinto por ela. Ela está com Alzheimer".

\section{3 - A luz do menino Alcides}

"Nasci na cidade chamada Estrela do Sul, lá em Minas Gerais, em 1947, então hoje eu estou com sessenta e sete anos, $e$ eu estou assinando agora, Serewatu, depois do meu batizado xavante. Serewatu em xavante significa sonhador, o veloz e o sábio... Eu nasci nessa cidade, lá no triângulo. Eu sou de uma família de congo, de congado.

Eu nasci numa fazenda chamada Fazenda da Limeira, que fica próxima à cidade Joaquim Antônio, que é município de Estrela do Sul. Minha mãe era analfabeta, chamada Maria Rosa de Lima, meu pai é Antônio Rosa de Lima. Meu pai na época já era uma pessoa estudada, ele já tinha o quarto ano primário, era formador de cafezais nessa fazenda. Meu pai era 
muito inteligente nessa área de cultivo. Ele coordenava nessa fazenda desde derrubar a mata, naquela época, mata virgem, até colher o café, plantar. Coordenava um grupo muito grande de homens, plantava, cuidava, o café crescia e ele coordenava a panha desse café. Ele coordenava a embalagem, o ensacar desse café e coordenava até a venda desse café para o fazendeiro, que era uma pessoa de muita credibilidade. Mas era um trabalho escravo. Meu pai não ganhava praticamente nada para fazer isso, tanto é que a minha mãe trabalhava na fazenda de cozinheira, cozinhando para sessenta, setenta peões, porque esse povo todo comia na fazenda e minha mãe trabalhava praticamente de graça. Eles estimulavam os casais a ter muitos filhos, tanto é que meu pai e minha mãe tiveram treze filhos, porque os filhos trabalhavam de graça e só começavam a ter salário na maioridade.

Nessa época já discordava disso, eu já não queria ir para a roça trabalhar. Aí, minha mãe me levava para brincar com os filhos do fazendeiro. A gente era mais um objeto de brinquedo do que um companheiro de brincar.

Minha mãe era uma negra muito bonita, não é por ser minha mãe, não, mas ela era uma pessoa muito alegre. Naquela época minha mãe era uma revolucionária porque ela tocava cavaquinho muito bem, ela cantava muito bem e na época que mulher não andava a cavalo montava igual homem, ela já vestia uma calça rancheira e subia em cima de um cavalo. Quando ela não estava na fazenda estudando, ela ia para cidade comprava é louças, e panos de chita e tudo e ia levar para outras comunidades, vendendo. Ela não sabia escrever, eu acompanhava para fazer as contas, mas ela fazia tudo os 
cálculos de cabeça, de memória, então, tudo que ela fazia eu só confirmava porque eu já era alfabetizado. Era uma pessoa inteligentíssima, tinha uma visão de mundo muito grande, uma sabedoria imensa, uma pessoa maravilhosa. Meu pai tinha todo esse saber, todo esse conhecimento dele de alfabetizado, mas quem mandava na casa, em tudo, era minha mãe. Meu pai não mandava em nada, até as roupas para o meu pai, minha mãe que comprava. Ela comprava do jeito que ela queria e ele vestia sem reclamar. Eu costumo dizer que quem me deu toda questão de homem para mim, foi minha mãe, não foi meu pai. A minha formação de homem foi minha mãe que me deu. Minha mãe, que me fez homem, ensinou todo mundo a lida da casa, fazer comida, fazer bolo, fazer café, limpar casa... colaborar, entender, respeitar".

\section{4 - A origem da luz}

Os textos trazem uma pequena apresentação dos personagens que compõem esta história. Alice, Matheus e Alcides se identificam a partir de suas raízes, na localização geográfica de origem e na relação com os pais. Parece que só sabe mos o que somos, quando sabe de onde veio.

Uma referência à herança biológica, que Ferreira-Santos (2015, p.28) chama de "primeira-herança", aquela que "nasce-se numa determinada tradição e as provações da iniciação se pautarão sempre pelo exercício da memória: nunca esquecer o que se é e de onde se veio". 
Nossos mestres, personagens desta trama, também iniciam sua jornada no resgate de si mesmos, na memória de sua primeira ancestralidade.

Os mestres que nos ajudam a identificar a ancestralidade como

"(...) aquele traço, de que eu sou herdeiro, que é constitutivo do meu processo identitário e que permanece para além de minha própria existência (...) Isso me constitui, sendo consciente ou não desse traço.” (Ferreira-Santos, 2015, p.29)

Alice, personagem fictícia de uma história fantástica, não faz menção ao pai ou mãe, apenas nos é contado sobre o lugar onde vive - uma floresta encantada com seres de luz sob custódia de um dragão em uma caverna. Quem guia Alice em novos caminhos, lhe conta histórias e a acolhe são os meninos de luz, que vivem fora de sua caverna. É preciso que Alice saia para encontrar a luz, a sabedoria, o conhecimento, pois o ser que a acompanha apenas a destrata e a rejeita. Alice é impedida pelo dragão de emitir luz e deve viver nas trevas. O texto também nos retrata a distância vivida entre o dragão e Alice. Alice vive só, guiada por seus próprios instintos.

Matheus e Alcides iniciam sua apresentação nos contando onde nasceram e marcam seus traços de identidade por meio de seus nomes. Matheus enfatiza o "th" que marca o nome herdado o pai. Alcides se apresenta pelo nome completo, mas dá ênfase ao seu mais novo nome de batismo, Serewatsu, que marca sua passagem dentro da ancestralidade xavante, a qual dá sentido ao nos revelar o significado da palavra: o sonhador, o veloz e o sábio.

Ambos nos contam que, ainda muito pequenos, acompanhavam suas mães ao trabalho. Temos duas realidades 
distintas, distanciadas pela cor, pelo tempo e pela geografia. De um lado, um menino negro, filho de mãe analfabeta que trabalhava de forma quase escrava para fazendeiros da região, mascateava nos arredores e esbanjava feminilidade na audácia da cultura expressa em sua música e em seu corpo.

Do outro, um menino branco, filho de mãe letrada e professora, que passava dias longe de casa trabalhando nas fazendas dos arredores, ensinando os filhos dos empregados e dos patrões.

Onde podemos chegar com estes vestígios?

A priori, busquei entender as relações arquetípicas entre o feminino e o materno e explicar o personagem "dragão" que aparece na história de Alice como um símbolo nefasto do arquétipo materno (Jung, 2002a).

Alice está repleta de imagens simbólicas carregadas de sentidos que exteriorizam meus afetos, criadas por meio do resgate da memória e percepções da infância. Seria muito superficial e simplista cair em análises psicanalíticas que pudessem justificar as relações que estabeleci posteriormente com meus mestres. As histórias de vida dos mestres, por outro lado, poderiam enriquecer esse tipo de análise no aprofundamento dos discursos que tratam sobre as mães e sua importância na primeira infância.

O fato é que a escrita sobre minha vida me fez percorrer um caminho árduo para dentro de mim e de volta à minha infância. Trouxe-me dor e um sentimento de profunda covardia para me ver de perto. Como no mito de Orfeu, na busca pela minha ancestralidade por meio do resgate da memória, a ordem de não olhar para trás não foi obedecida e eis que me senti 
completamente perdida, com a cabeça rolando em meio à montanha. Tornei-me medusa de mim mesma ao olhar minha imagem no espelho e me tornei pedra. Ao contrário de Narciso que se afogou no próprio querer-se, eu petrifiquei.

Sem saber por onde ir, por onde começar e como afastarme de mim para a produção do texto, busquei orientação. Literalmente, busquei em Ferreira-Santos uma resposta para a questão: por que esse tema? O que haveria de extraordinário, poético, acadêmico ou sábio nas entranhas da minha própria vida?

Num momento pensei que não fosse a minha vida, mas a vida de meus mestres. No entanto, a luz veio e parafraseando Ferreira-Santos $\left(2005^{\mathrm{a}}\right)$ : “Antes ainda de tentar encontrar a chave da interpretação, é preciso saber onde se encontra a porta."

Busco agora a porta para o caminho. Descobri nas releituras de seus textos uma vazão para os sentidos, um lugar para a minha escrita.

A porta para o início da interpretação dessas histórias, talvez seja o regresso, a busca por mim mesma, por minhas raízes. Buscar entender também quais são as raízes daqueles que me guiaram e o momento dos encontros que nos tornaram um texto, um tecido, uma trama de vida.

"No seu enraizamento encontramos a paisagem que habitamos e o corpo que somos. Entrelaçamento profundo, este é o 'cruzamento das avenidas ': ou como diria ainda Merleau-Ponty: o chiasma, ponto em que se fundem a carne do mundo e a nossa própria carne. No interior do mundo, o nosso mundo interior" (Ferreira-Santos, 2005a). 
Compreendi, finalmente, a minha linha de pesquisa. Nossas análises partem para os caminhos da mitohermenêutica, tal como esclarecida por Ferreira-Santos:

"Uma hermenêutica simbólica de cunho antropológico que se apresenta tanto como estilo filosófico - no sentido de manter uma atitude de inquietação e questionamento; como método de investigação - no sentido de estabelecer procedimentos sistemáticos de pesquisa acadêmica. Esta mitohermenêutica, na reflexão sobre a educação, se debruça sobre a interpretação das obras da arte e das culturas, mas, principalmente, situa a compreensão de si mesmo como ponto de partida, meio e fim de toda jornada interpretativa. Portanto, não se trata de uma simples técnica de interpretação, mas uma jornada interpretativa em que o hermeneuta se instala na paisagem cultural das obras com que trabalha, viaja ao seu interior e reconstrói os sentidos de tal imersão" (2008, p.05).

O ponto de partida é a busca por mim, o caminho é compreender os fenômenos que me transformaram em quem sou, e os processos envolvidos em minha formação. Processos que ultrapassam os muros da escola branca, conservadora, de paredes e cadeiras-castigo. Vou à busca de tentar entender os ditos da vida, as experiências sentidas, o corpo soprado na areia, a areia que em algum momento vira rocha e a rocha que se desfaz no vento e volta a ser grão livre no tempo.

"Este é o universo da carga vivencial que permeia a trajetória das pessoas concretas. Muito antes e muito além das prescrições do dever-ser, este é o fluxo cotidiano do fazer. Domínio da práxis, prática permeada da reflexão e reflexão permeada de prática que se faz, cotidianamente, competente com o viver e compromissada com o conviver, com todas as contradições e paradoxos próprios do mundo real. Aqui as narrativas de vida se constituem e se entrelaçam numa trama convivial" (Ferreira-Santos, 2012 , p.27)

Antes da jornada de leitura mitohermenêutica, julgo relevante mostrar o caminho de equívocos e negação que percorri até compreender qual o meu objetivo de fato.

Minha leitura inicial foi que meus mestres tiveram como seus primeiros mestres suas próprias mães e que eu não havia 
tido essa oportunidade e que, por isso, buscava fora o que não tinha dentro. Gusdorf (2003), porém, cita que a relação entre pai e filho não pode ser considerada uma relação mestreaprendiz. Em suas palavras:

"O vinculo que une o filho ao pai é o oposto dessas diversas relações de subordinação. (...) a criança está diante do pai em estado de menoridade. Porém, essa menoridade é, ao mesmo tempo, acidental - pois a criança nada pode contra ela, seu nascimento foi pura contingência - e essencial, pois o vinculo de dependência afirma uma responsabilidade recíproca de tal maneira que os dois participantes só muito dificilmente podem esquivar-se dela. Não se trata de um contrato temporário ou revogável, mas de um encontro imposto pela natureza que faz sentir sua pressão enquanto um dos interessados estiver vivo. Nunca deixamos de enfrentar nosso pai, de dialogar com ele, como claramente mostram a psicanálise e a psicologia moderna" (2003, p. 96)

Gusdorf cita a relação maternal e fraternal como tipos deste mesmo vínculo, apesar de explorar muito mais detalhadamente a relação pai-filho. No mesmo texto Gusdorf cita ainda a falta de liberdade existente nesse tipo de relação, "razão pela qual, via de regra, os pais, mesmo quando pedagogos, têm tanta dificuldade em ensinar seus próprios filhos" (p. 97). Ou seja, se eu não tinha isso dentro de mim, como muitos de nós, a busca se deu por outros fatores que se relacionam a minha própria personalidade.

Gusdorf caracteriza o discípulo como aquele que "está à procura de si mesmo, não se pertence" (p.94). Ora, mas nessa fase da vida em que se encontram nossos três personagens, todos estavam na mesma situação. Porém, há algo que se sobressai em Alice - esse conto se refere à minha primeira infância, momento em que morava numa casa que dividia quintal com mais três casas num cortiço na Mooca. Tinha quatro ou cinco anos no 
máximo e já tinha em mim essa vontade de buscar as palavras que me levassem para outras realidades, que me ajudassem a encontrar outros caminhos. Tinha fome de aprender. Nasci discípula.

Resolvida a questão do "arquétipo materno", surgiram outras para a composição do texto. Em que elementos me apoiar para traçar paralelos entre as histórias de vida? Como encontrar as ressonâncias? Como encontrar respostas ainda que provisórias?

Encontrei mais uma vez a resposta em Gusdorf: "O que o mestre ensina de melhor, de essencial, tirou da experiência de sua vida" (p.86). A experiência dos meus mestres me foi relatada em suas histórias de vida e daí devo tirar o néctar que me conduzirá à compreensão do porquê de terem se tornado meus mestres. A ideia, então, não é analisar e construir pontes que determinaram destinos, mas entender porque me reconheço nestas pessoas, porque estas pessoas foram aquelas que me desvendaram minhas necessidades mais íntimas, como colocado pelo próprio Gusdorf (2003).

$\mathrm{O}$ pouco que podemos concluir com as histórias que contamos até aqui é que Mestre Alcides e Matheus foram crianças que aprenderam com suas mães a respeitar a figura feminina, a respeitá-las pelo seu oficio, pela sua força, pelo afeto que ofereceram na maternidade. Da minha Alice, o que também se pode concluir é que, desde que se sabe gente, buscava na palavra das histórias contadas a chave para um mundo de descobertas e imaginação, um caminho para o conhecimento. $\mathrm{O}$ que Ferreira-Santos (2005a) nos explica como o "axé" da cosmovisão africana, a força vital que sai pela parte sagrada do 
corpo, que é a boca. A forma como me sentia viva, já era em si um indício prematuro da minha ancestralidade.

E esse talvez possa ser o fio condutor desta primeira parte da jornada, que nos ajuda a entender um pouco mais da infância dos meus mestres e das aventuras de Alice... A ancestralidade.

Mestre Alcides, quando iniciou a entrevista sobre sua história de vida, cantou um ponto de congado. Seu canto veio carregado de vida, de história, de ancestralidade:

"Quando eu fui para Curumbá grande

Eu passei no jo de jambé

O nganga tava no altar

Eu com meu tipunga na mão

Ó marunga joelha no chão

Ó marunga joelha no chão

Ó marunga joelha no chão

Quando eu pisei nesse chão

Eu senti a terra tremer

Eu pensei que fosse meu peso e não era

Era o peso de você

Ó marunga joelha no chão

Ó marunga joelha no chão

Ó marunga joelha no chão

Ó marunga joelha no chão

Amanhã eu to indo embora

Mas eu pretendo voltar

Eu quero pedir permissão, ai meu Deus

Pro povo deste lugar

Ó marunga joelha no chão

Ó marunga joelha no chão 


\section{Ó marunga joelha no chão}

Ó marunga joelha no chão"

Sobre o Congo e o ponto, o mestre explicou: "Eu sou de uma família de Congo, de congado, então, a minha iniciação nas culturas tradicionais e nos congados deu desde eu na barriga da minha mãe, eu com oito anos, comecei a dançar congado. O congado que até hoje existe. Eu vou lá, ainda, faço parte do grupo. O capitão é meu tio, fez 90 anos agora, dia seis de janeiro. Eu só entrei criança porque eu aprendi tocar sanfona oito-baixo, aquela que a gente chama de pé-de-bode, foi uma das possibilidades de conquista para eu poder entrar no terno porque era só velho que dançava. Nem criança, nem mulher dançavam. Então, para abrir essa conversa eu vou cantar um ponto que a gente dança para a Senhora do Rosário, São Benedito ou Divino Espírito Santo, mais para São Benedito que é o Santo dos Pretos. Essa é uma espécie de uma ladainha de capoeira, que conta a caminhada do negro nessa época, saindo da fazenda, da zona rural para a zona urbana, a senzala e a cidade. Sempre existe uma capela, a capela de um santo, ou São Benedito ou Senhora do Rosário, enfim, essa ladainha conta esse percurso, quando a gente sai da fazenda e vai para a cidade, a gente passa nessa capela, ajoelha, tira o chapéu da cabeça e reza".

Mestre Alcides entoou a ladainha para explicar sua ida para São Paulo, mas ela estava carregada de infância, o berço que nunca negou a sua ancestralidade, o que foi, sem dúvida, uma das experiências nas quais me reconheço. 


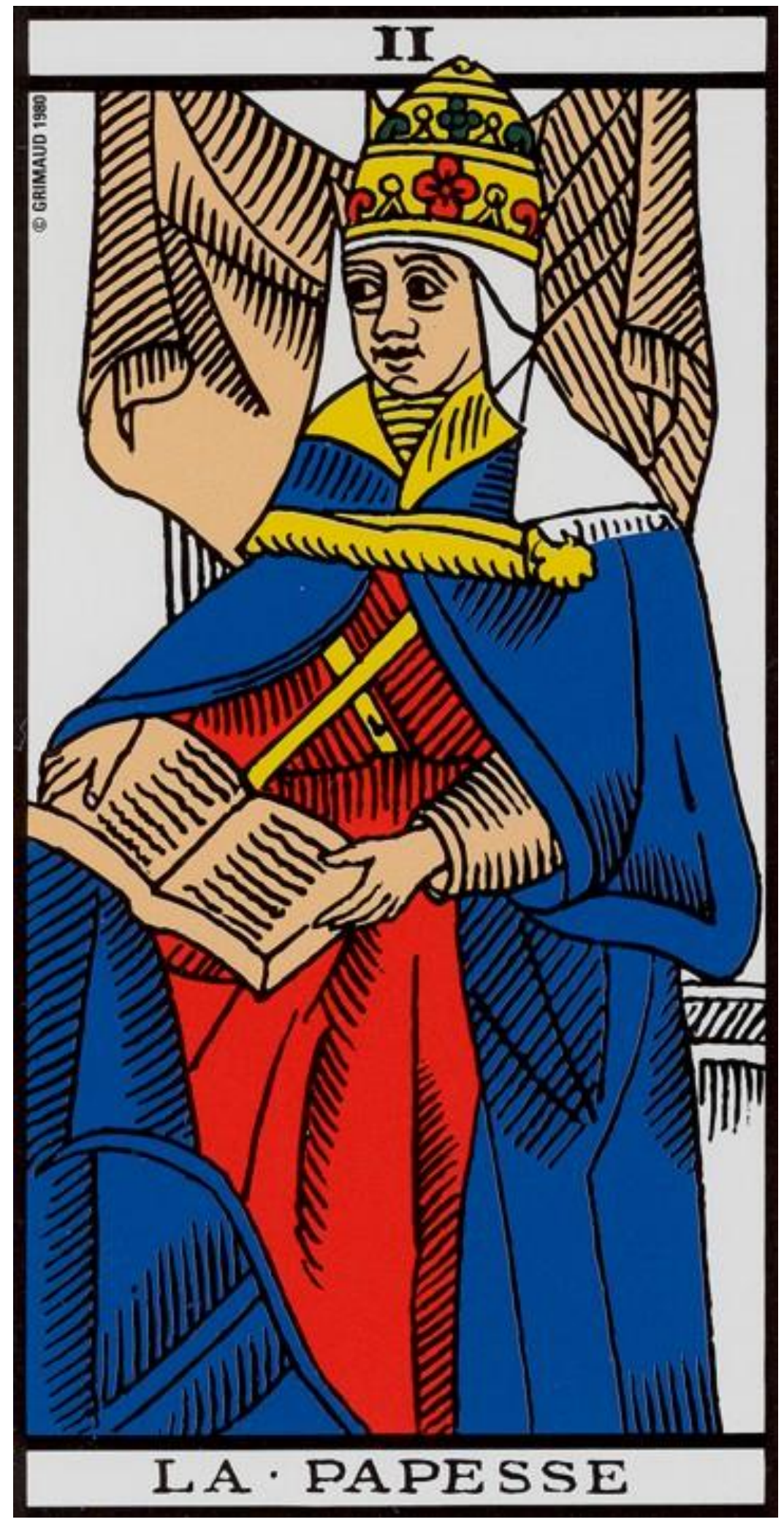




\section{2 - O dragão e a menina Alice}

O dragão vivia só em seu mundo de magia. No mundo de magia viviam apenas seres mágicos e não havia registro de seres humanos capazes de viver ali. Havia histórias de alguns humanos dotados de capacidades especiais que descobriram o mundo de magia, mas não suportaram viver muito tempo por lá, transformando-se em ostras que vivem no fundo do mar.

O dragão, porém, havia tentado viver no mundo real... onde foi brutalmente maltratado por humanos. Nunca perceberam que o dragão era um ser do mundo de magia. Num certo dia, viram o dragão andando perdido pela rua e logo gritaram:

"Esse deve ser bom para puxar"

"Esse deve ser bom para carregar"

"Esse deve ser bom para subir"

"Amarrem o bicho e o coloquem para trabalhar"

Ninguém nunca se deu conta que aquele bicho tinha asas, tinha brilho no olhar, tinha cores no hálito de canela que exalava toda a vez que se punha a cantar. Ninguém percebeu que aquele era um ser-dragão.

Depois de ser explorado, machucado e humilhado o ser dragão encontrou em um homem a possibilidade de voltar para o mundo de magia... O homem bom, na verdade, não podia fazer nada pelo dragão, apenas escutá-lo.

Foi crueldade desse homem alimentar a esperança do dragão. O homem pensava que o dragão era apenas um bicho esquisito que sabia falar. O homem nunca soube sobre mundos de magia, não podia ajudar. 
Certo dia, o homem cansado de tanto ouvir o dragão se lamuriar, deu a ele um espelho. No espelho o dragão viu seu reflexo, em seu reflexo, suas asas... Lembrou-se que podia voar.

Com o pouco de força que lhe restava, decidiu tentar fugir, juntou toda força que tinha e num ato único de bravura abriu suas asas com toda envergadura. Quebrou móveis, janelas e paredes e saiu do chão.

Num gesto de agradecimento ao homem do espelho, o dragão o tirou do chão e o carregou para seu mundo de magia. Apavorado, sem brilho nos olhos e sem cores no hálito, o homem ficou desesperado.

Não sabia de vôo, nem de cores, nem de sonhos e os meninos de luz o cegavam cada vez que apareciam para falar com o homem. Um dia, andando perdido, sem saber o que fazer para enganar o dragão e voltar ao mundo dos homens, encontrou uma lagarta gigante que se alimentava de folhas caídas no chão.

Ao se aproximar, percebeu que o intestino da lagarta compunha lindas canções de Malpighi durante a digestão e que aquele podia ser um bom presente para distrair o dragão enquanto tentava fugir. Assim, o homem amarrou a lagarta com inúmeros fios de seda, prendeu no chão com estacas e foi chamar o dragão.

O dragão maravilhado com tamanha prova de amor ficou cego. Não via nem ouvia mais nada, só tinha olhos para lagarta, só tinha ouvidos para as canções de Malpighi. Ficou ali dias, parado, extasiado. O homem fugiu e quando o dragão se deu conta que fora enganado, se voltou feroz para a lagarta culpando-a pela perda do seu homem bom. O dragão arrancou 
a lagarta do chão e a levou para sua caverna. Nunca mais a lagarta teria paz, nunca mais o dragão teria brilho no olhar.

Da lagarta, nasceu Alice, que não nasceu borboleta por falta de paz na digestão. 


\section{1 - Sobre as cigarras, as borboletas e as cantigas que a gente ousa cantar}

A lagarta compunha canções. Alice em sua fase larval transbordava música e na música encontramos ancestralidade negra, índia, ameríndia.

Mestre Alcides também começa sua história nos presenteando com um canto. Distanciados em anos de vida, iniciamos a jornada no canto, mestre em seu papel de griot nos brinda com a luz de sua primeira ancestralidade, aquela que carrega consigo, ensina e o guia. $\mathrm{Eu}$, em minha pequenez de lagarta, não tinha canto, tinha só um embalo primitivo que saia de dentro, do instinto puro.

Essa conversa, lembrou minha avó cantando para mim "baile na roça meu bem, se dança assim, pego na cintura dela e ela, tarraca em mim...”, música de Tonico e Tinoco que ouvíamos no fim da madrugada, início do dia, quando ela se levantava para passar o café. Minha mãe saia bem cedo para o trabalho e eu ficava com a minha avó, que foi quem mais cuidou de mim na primeira infância. Minha avó quando cantava, colocava as duas mãos na cintura e pendia os quadris de um lado para o outro com um sorriso imenso no rosto.

Nos cantos, nos jeitos, na dança do corpo marcado de minha avó, minha ancestralidade caipira, cabocla, do mato. Como Mestre Alcides, minha história também é marcada pelas cantigas dos mais velhos, com fortes referências ao simbólico religioso e ao lugar de pertença no mundo. 
"Essa corporeidade, esse nó significativo vivido, cruzamento da carne do mundo com a minha própria carne, sinaliza o caráter dinâmico da cultura como processo simbólico. Percebemos, então, que a base imaterial da cultura, de maneira paradoxal, é uma base corporal, assim como nos cantos populares ou iniciáticos, na base rítmica do canto de pilão, no ritmo das pernas e braços da dança comunitária: amenizar a arte da vida desse socar de palavras, ritmados no canto, na organização do tempo, na comunicação das almas...” (Ferreira-Santos, 2004, p.148)

Essa referência ancestral que nos permite compreender nossa própria identidade. Curiosamente, uma das cenas que tenho em mente de maior significado na minha relação com Matheus era a música que cantava para mim, toda vez que minhas palavras se perdiam em meio a minhas angustias durante nossos estudos de campo: "Ando devagar porque já tive pressa e levo este sorriso, porque já chorei demais" (Almir Sater). Matheus olhava para mim com olhos cheios de ternura, mas tinha em seu olhar uma mensagem não expressa em palavras, mas expressa na profundidade com que me tocava a alma.

Essa ligação pelo canto, Ferreira-Santos (2015, p.32) explica como "a estruturação musical da palavra, portanto, organização temporal de ritmos, frequências e timbres que demonstram a profunda tessitura da palavra". Palavra esta proferida pelos mestres que nos conectam com o mundo e nos guiam na busca da compreensão de quem somos e para onde devemos ir.

Matheus, por sua vez, em seu relato de vida menciona as festas em família e os encontros de domingo como seu lugar ancestral, sagrado, do aprender a ser: “A gente ia passar o final de semana em Ribeirão Bonito. Pegava a Maria Fumaça, trenzinho, descia para Ribeirão Bonito no sábado de manhã, 
perto do almoço, ia almoçar com meu avô, com os meus tios e ficava até domingo lá. Voltava domingo. Pegava o trem de volta e era assim."

O diálogo familiar, o encontro, a partilha do alimento que transforma o corpo e a alma. Essa memória que permite o resgate de um passado presente na constituição do ser quem somos: "Aquele passado que trazemos no sangue e, por vezes, nem nos damos conta de que o temos tão vivo em nós." (Ferreira-Santos, 2015, p.33)

\section{2 - ... E fez-se a luz}

Esse conto de Alice trata um pouco sobre a história que vem antes da minha história. Tentei retratar aí a história que me contam sobre meu nascimento e o romance entre meus pais. Vejamos uma investigação sobre as metáforas que antecedem o aparecimento de Alice.

Meu pai nunca me assumiu enquanto pessoa. Fui registrada com seu nome só aos 18 anos por pressão da minha mãe. Não sei dizer qual era exatamente sua preocupação, se com uma possível herança, como ele dizia, ou se por orgulho, por direito ao reconhecimento do relacionamento que teve na juventude. Nunca soube se era por mim ou por ela.

Sei que para mim nunca fez bem, nem antes, nem depois. Antes o incômodo era pela falta do nome do pai, depois pelo nome de um pai que nunca quis dar seu nome a mim. Até hoje não sei exatamente qual meu sentimento sobre essa questão. Meus filhos não têm nenhum sobrenome meu. Histórias tristes devem ter fim antes de outras histórias começarem. 
E se a autobiografia deve ter uma tentativa de compreensão, porque é parte de uma tese ficcional, recorro a Sartre (2008), que trata sobre as emoções. Alice é só uma representação simbólica do que sinto diante do pouco que sei e do muito que vivi. Alice trata dos meus sentimentos sobre as pessoas, sobre as ocasiões, sobre as experiências que vivi. Alice é um esboço das minhas emoções diante do resgate de minha memória, do meu passado, que para Merleau-Ponty não é passado, é presente, porque está dentro, porque está acessível, porque o corpo reage, mesmo que apenas na escrita de um texto.

Sobre as emoções, estas trazem o que foi meu mundo na infância - "a emoção remete ao que ela significa. E o que ela significa é, de fato, a totalidade das relações da realidade humana com o mundo" (Sartre, 2008, p.93), - a minha relação com o meu mundo, o que eu sou e fui no mundo que vivi.

\section{3 - Sobre os nosso quintais}

Quando li as histórias de vida de meus mestres, algo me chamou atenção - a relação com o espaço físico em que cresceram. Ambos lembram com detalhes os quintais que lhes pertenceram. Se não foram quintais de suas casas, foram as ruas, os matos, as árvores, os jardins de sua infância.

Ferreira-Santos (2006, p.47) cita Bachelard e Tuan para explicar o termo topofilia, que seria "o sentimento intenso de pertença e/ou frequentação amorosa a um espaço, região, território...”. Alice também trata sobre este espaço, e sobre ele, podemos nos aprofundar. 
Cresci numa casa de fundos, que dividia o quintal com mais três casas. Todas muito pequenas e muito simples. Minha avó cuidava de mim, enquanto minha mãe trabalhava. Todo dia acordava com minha avó e ia dormir com ela. Pela manhã, ouvindo o programa sertanejo no rádio, minha avó cuidava das plantas. Ela tinha uma relação fortíssima com a terra. Nosso quintal era de cimento, mas muitas latas de tinta serviam de vaso e tínhamos muitos tipos de plantas: comigo-ninguém-pode, alecrim, arruda para benzer de todo mal e outras tantas que minha avó regava todos os dias de manhã com uma alegria danada no rosto.

Ela era uma mulher da roça, veio para São Paulo ajudar minha mãe a cuidar de mim, já que meu nascimento impossibilitava minha mãe de continuar morando na mesma cidade pequena de interior que meu pai. Não me lembro de minha avó reclamar da vida em São Paulo, mas lembro dela manter hábitos que não eram urbanos. Aliás, eram peculiares, mas hoje já tendo morado na roça, sei que era o que ela sempre foi.

Matheus quando fala de sua infância: "Meu pai construiu uma casinha, nós saímos da casa da minha avó, eu já tinha já uns quatro ou cinco anos. Era fora, era bem retirado na época, era como se fosse uma fazenda, não tinha casa nenhuma em volta, era só mato e hoje tá tudo cheio, construído. Então eu cresci ali. Foi bom para mim porque eu cresci no meio daquela natureza, eu gostava muito de natureza. Eu vivia naqueles campos ali, perambulando, caçando passarinho, borboleta, tinha muitas borboletas. Minha mãe fez para mim um coador, sabe aqueles de aro, depois põe um tule. Um puçá! E eu ficava 
caçando borboleta lá naqueles campos e pegava as borboletas e levava para casa e soltava na sala da minha casa que tinha uma cortina e elas iam tudo na cortina porque via luz e eu ficava admirando aquelas borboletas. Adorava ver aquilo, elas abrindo e fechando a asa. Às vezes corria para o riozinho pescava uns peixinhos, girino de sapo, rã e assim, vida livre."

Vida livre esta que eu quero ter. Conheci Matheus em São Carlos, no Centro de Recursos Hídricos e Ecologia Aplicada da USP (CRHEA). Terminei a graduação, queria fazer mestrado, prestei, não passei, mas fui convidada para me inscrever no curso de Educação Ambiental de que Matheus era coordenador. Foi uma das experiências mais incríveis da minha vida. Eu já trabalhava com educação ambiental, mas o curso do Matheus trazia algo mais, um fazer amar e respeitar que em nenhum outro espaço acadêmico eu havia visto. Esse brilho nos olhos que conseguimos ver quando se lê a imagem descrita no texto, Matheus carrega consigo, principalmente quando se trata da natureza e das pessoas que estão nessa natureza... e até das que não estão.

Mestre Alcides, também fala um pouquinho do seu quintal: "A minha infância foi na roça, foi tomando banho nos córregos, caçando passarinho de estilingue, comendo frutas silvestres, goiaba, castanha do coco da macaúba, uva. Brincando de esconde-esconde no mato, pulando nos galhos das árvores, andando a cavalo".

Para entender um pouco mais sobre este sentimento de pertença ao espaço, busquei em Tuan (1974) um aprofundamento sobre o conceito. Antes de tratar do termo "topofilia”, Tuan traça um caminho textual que explica um pouco 
sobre a maneira como o homem percebe um ambiente, seus recursos de percepção e sentidos, a relação com aspectos psicológicos, comportamentais e culturais para, por fim, definir o conceito e explicar como a relação do homem com o lugar em que vive pode definir valores humanos e bem-estar.

Ao longo do texto Tuan explica a natureza do homem do campo e do homem urbano, os sentimentos do homem com a terra e como se repercute no trato com o espaço e no social. Ferreira-Santos (2006, p.59) complementa:

"Esta filia se expande da convivência das pessoas, objetos, lugares para a casa e seu entorno. O sentimento de pertença faz com que deixe de ser apenas um 'ocupador' do espaço-tempo para ser, a própria pessoa, parte da natureza ambiente em sua fusão cognoscente e simbólica.”

A formação de Matheus e Mestre Alcides se deram no campo, no trato com a terra, com a natureza. Eu tive um pouco disso no meu quintal, mas fui buscar o que me faltava mais tarde, na graduação e encontrei em Matheus um caminho para entender e aprender um pouco mais sobre o valor da terra e com Mestre Alcides um pouco mais sobre essa gente que vive na terra e faz brotar da terra sua cultura, sua gente e seu valor. 


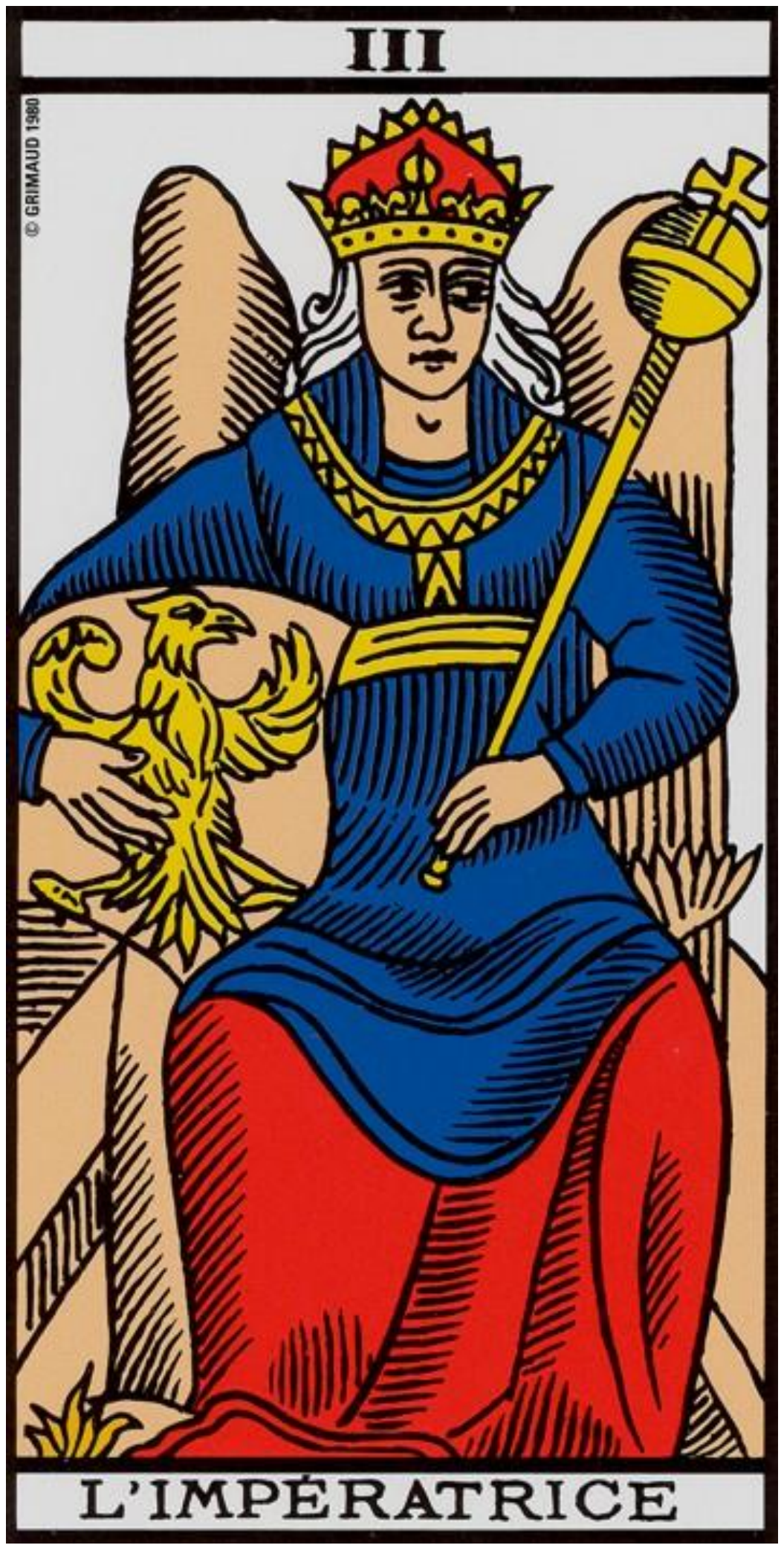




\section{3 - Alice entre o Bem e o Mal}

Um dia, Alice estava deitada na relva conversando com os meninos de luz, quando de repente eles desapareceram. Meninos de luz são assim, eles estão sempre por perto... Quando as flores estão abertas, quando o Sol brilha, quando orvalho cai na terra... Mas ao menor sinal de comedores de luz, eles desaparecem. Meninos de luz temem os comedores de luz.

Alice estava no meio de uma história quando se deu conta de que falava sozinha. Percebeu um silêncio profundo... uma certa tensão, uma solidão que consumia o espírito. Sabia que suas asas não apareceriam nesta situação. Ficou quieta, na tentativa de não chamar a atenção... de se fazer invisível. Mas com tanto brilho, Alice acabou atraindo um comedor de luz. Ao se deparar com figura tão tenebrosa, Alice ficou sem ação, mas ao mesmo tempo curiosa... "O que seria este ser? Por que tanto silencio e tanta solidão? O que um ser apagado, sem força, sem energia, sem rosto... poderia fazer de tão mal?”

Alice se sentiu fraca... não suportou a presença do comedor de luz e desmaiou. Nesse dia, Alice se deu conta de que havia seres que faziam mal e que mesmo não vendo problema em conviver com eles, seria preciso que fizesse escolhas... porque ela não daria conta de transformar estes seres em meninos de luz. 


\section{1 - Deus e o diabo numa terra sem Sol}

A escrita de Alice, como foi dito anteriormente, se dá em meio à escrita da minha autobiografia. $\mathrm{O}$ processo é lento e não produzo os contos de Alice em qualquer momento da escrita. Vou escrevendo sobre minha vida e em algum momento nasce um conto de Alice. Normalmente, esses contos nascem quando trato de questões delicadas ou pesadas emocionalmente, mas não são escolhas conscientes. Nem sempre nasce uma Alice, é meio ao acaso.

Às vezes, quando leio os contos separados da autobiografia, não lembro porque nasceram ou ao que se referiam. A verdade é que Alice quando vai para o papel ganha vida própria e é como se eu tivesse que articular mais uma história de vida à pesquisa. Quando li esse conto, me lembrei que foi escrito quando me referia à questão religiosa na infância e não soube fazer a leitura simbólica do conto. Reli a autobiografia e a imagem da Alice caída automaticamente me lembrou a da minha mãe caída no centro de umbanda.

Agora, começamos a permear o campo religioso desta história.

Minha avó era muito católica, rezava todos os dias em casa, acendia velas, benzia tudo e para a reza das seis da tarde havia um ritual: ela me chamava no quintal, eu entrava, ela fechava as portas, acendia a vela em frente a Nossa Senhora de Aparecida, colocava um véu em sua cabeça e na minha. Ajoelhávamos em frente à santa e rezávamos a Ave Maria junto com o locutor de rádio.

Minha mãe não participava de nenhum desses rituais propostos por minha avó. Ela frequentava um terreiro de 
umbanda aos sábados à noite e, por vezes, me levava com ela. Lá, eu ficava com as outras crianças brincando.

Não sei dizer o que era para mim ir ao centro de umbanda com minha mãe. Eu gostava do lugar, das pessoas, da festa e das comidas, mas não gostava de ver minha mãe da maneira como ela ficava.

Minha mãe, ao contrário das outras pessoas que me cercavam, não gostava muito de conversar comigo, de contar histórias e explicar as coisas do mundo. Assim, tudo que eu via naquele centro era analisado e compreendido de acordo com meus recursos, que não eram muitos.

Apesar de ninguém nunca ter dito se o que acontecia ali era bom ou ruim, eu não gostava de ver minha mãe girando, gritando e se comportando como uma louca quando entrava no meio da roda da festa. Eu não tinha nenhum discernimento quanto ao ritual ou do seu significado. Lembro-me das pessoas de branco, dos fios de conta, dos tambores, da energia forte que tinha aquele lugar, mas nunca ninguém me explicou nada sobre o que eu via ali.

Minha mãe ficava assim como quando ela perdia a paciência com algo em casa: enfurecida. E eu tinha medo, muito medo do que ela podia fazer quando ficava daquele jeito.

Meu tio Claudio sofria de epilepsia, o que explica facilmente o seu estado depois de beber. Tomava remédios fortes para conter os ataques que aconteciam com frequência. Quando meu tio tinha um ataque, geralmente estávamos sozinhos em casa (eu, minha avó e ele). Minha avó, desesperada, pegava uma caneca de água e começava a jogar nele, rezando para todos os santos, pedindo ajuda para que o "espírito ruim fosse embora". 
Acho somente que com dez ou onze anos eu viria a saber perfeitamente o que era epilepsia. Antes disso, tudo era uma grande confusão na minha cabeça.

Meu tio ficava parecido com minha mãe no centro de umbanda, mas um era doente e a outra estava "incorporada". Minha avó ficava "louca" em ambas as situações, tentando resolver com suas rezas e benzeduras e eu ficava ali, assistindo, sempre assistindo, sem saber o que fazer em qualquer uma das situações.

Minha mãe frequentou o centro durante muitos anos. Mas depois de algum tempo, fui podendo escolher entre ir junto ou não e logo deixei de ir. Tinha medo e guardei esse medo até bem pouco tempo atrás. Meu tio continuou tendo ataques, sendo alcoólatra e morando com minha avó até falecer. Por opção, deixei de compartilhar dos momentos de ataque do meu tio e de incorporação da minha mãe. Aquilo tudo era muito sofrido para $\operatorname{mim}$.

\section{2 - A religiosidade como desejo de pesquisa}

Quando comecei a treinar capoeira em 2011, Mestre Alcides me apresentou ao mundo de matriz africana. Não sabia que este mundo existia. Não sabia que vivemos ainda em um apartheid, que existe um mundo que só brancos frequentam e que está cheio de valores branco-ocidentais; e que existe um mundo que só negros frequentam - os negros, e os brancos que se sentem negros.

Quando conheci o mundo afro, me apaixonei por ele. Algo ali pulsava em mim junto com os tambores, com os ritmos, com 
os toques. Justamente ao que nos referimos anteriormente, algo maior do que eu, que vinha de dentro era desperto naquele mundo. Como me disse uma amiga mãe pequena de santo e negra: "A Carla é bege por fora e toda preta por dentro".

A disciplina que cursei em 2012 no início do doutorado, ministrado pela Profa. Diana Vidal, trouxe para minhas mãos alguns textos que tratavam do sincretismo religioso no Brasil e este foi meu tema de seminário. Estudei muito para a apresentação e um dos materiais que me serviu de base foi o documentário "Atlântico negro: na rota dos orixás" (1998), um belíssimo trabalho, dirigido por Renato Barbieri e filmado nos estados do Maranhão e Bahia, no Brasil; e Benin, na África. O tema é a religiosidade brasileira de raiz africana. $\mathrm{O}$ filme é feito a partir de pesquisas históricas, depoimentos e entrevistas com sacerdotes de religiões africanas e brasileiras, além de estudiosos da área. Parte do documentário trata sobre a volta dos escravos libertos ao continente africano, o impacto da cultura levada por eles e do "abrasileiramento" de hábitos e costumes no Benin. Entre as manifestações religiosas brasileiras contempladas neste trabalho estão o candomblé da Bahia, umbanda e o tambor de mina do Maranhão.

O sincretismo é um fenômeno que pode ocorrer na religião, na filosofia, na ciência e na arte e pode ser de tipos muito diversificados. Nas religiões afro-brasileiras podemos localizar vários tipos, conforme o aspecto que seja estudado ou a ênfase do estudo. O sentido etimológico da palavra sincretismo é "a união de cretenses", que na sua extensão significa "combinação pouco coerente (diferente ecletismo), mistura de doutrinas, de sistemas de crenças distintas" (Pereira, 2005). É 
um termo que pode servir como referencial para compreensão da influência de uma religião em outra.

Assim, podemos observar perspectivas opostas do termo: a de "simbiose", "interpenetração" e diálogo de culturas que se fundem e dão origem a uma "cultura nova" entre os grupos em contato ou da sobreposição de uma cultura em outra (Valente, 1977).

Não é difícil identificarmos o sincretismo nas religiões brasileiras. No Brasil, não temos um catolicismo puro. O catolicismo popular brasileiro, como colocado por Pereira (2005), acomodou nas suas devoções aos santos, os orixás das religiões de matriz africana. Temos assim, uma das características fundamentais da religiosidade popular brasileira: o paralelismo sincrético, ou seja, para cada santo da devoção católica, há um correspondente nos orixás. O Brasil, como já se sabe, é um país rico por ser um espaço onde as culturas se misturam, não deixando rastros de onde se inicia ou termina essa mistura cultural.

Este trabalho me fez entrar em contato com algo que nunca mais havia estado em meu mundo: a umbanda e o medo que eu trazia comigo da infância. O medo, segundo Sartre (2008) em seus esboços sobre as emoções, é uma forma de lidar com um "mundo difícil" que se apresenta sob nossa percepção, de modo a não buscar alternativas para lidar com essa dificuldade, mas fazendo-a "desaparecer".

Com poucos recursos na infância, minha percepção sobre esses aspectos do mundo devia ser de muita "dificuldade" e meu medo afastou esse mundo de mim durante todo o tempo que pôde. Mestre Alcides, ao me apresentar a capoeira e seu tambor, 
trouxe com eles um legado e uma história ancestral, que enfraqueceu este medo e aguçou em mim a curiosidade para entender melhor aquele espaço de misturas de valores, crenças e emoções.

\section{3 - Não era deus, nem o diabo; era a batida do tambor}

Toda minha forma de estar no mundo estava se transformando. A capoeira, junto com Mestre Alcides, haviam me descortinado um mundo e muitas outras coisas me chamavam para uma pesquisa. Muito mais do que um título, eu desejava aprender para dar mais sentido ao mundo.

" $O$ encontro com o mestre consagra um novo questionamento da existência”, diz Gusdorf (2003, p.76), e no meu caso não foi preciso maiores explicações. $O$ autor complementa: "Reconhecer um mestre para si é identificar a si mesmo, é aceitar a nova obrigação de procurar a plena realização na perspectiva bruscamente descoberta” (p.77). Eu segui meu chamado e mudei de linha de pesquisa no doutorado. Ainda vagando em mim, não sabia exatamente o que desejava estudar, mas no primeiro momento a religiosidade de matriz africana me pareceu um bom caminho.

Mestre Alcides, em seu relato de história de vida, nos diz quão importante foi, e é, sua iniciação religiosa dentro da cultura tradicional. Seu percurso foi inverso ao meu. O canto de congado que abre sua entrevista é também a porta de entrada para o mundo USP”, onde nos encontramos. Mas foi a capoeira que 
levou Mestre Alcides de volta à cultura tradicional e o transformou em mestre, como veremos posteriormente.

Matheus não mencionou nada sobre religião em sua entrevista, no entanto, no convívio com ele a religiosidade estava claramente colocada. Matheus é católico praticante e sua religiosidade é tão naturalmente vivida, que não é preciso que fale sobre ela, ela está em sua presença e atitudes.

Quanto à umbanda, durante minhas pesquisas e estudos sobre o tema, tive acesso ao livro de Stela Guedes Caputo (2012), que trata sobre a educação nos terreiros de umbanda e candomblé. Um trabalho de vinte anos de pesquisa sobre as crianças que crescem nos terreiros e como a escola lida com a religiosidade de matriz africana.

O livro, além de me trazer de volta um mundo vivido e tão temido na infância, ajudou a desmitificar muitas dúvidas e me trouxe para mais perto da questão do preconceito. Numa das passagens do livro, que acho de fundamental importância citar, a autora relata um ocorrido sobre intolerância e preconceito religioso no Rio de Janeiro. Antes de ser pesquisadora, Stela Caputo era jornalista e em uma ocasião fez uma reportagem sobre o tema. Nas palavras da autora:

"Ocorre que jornalistas e fotógrafos, quando fazem suas reportagens em uma empresa jornalística, produzem textos e fotos que pertencem aos proprietários do jornal. No caso do jornal O Dia, são de propriedade dos donos do jornal e negociadas pela agência O Dia. Qualquer pessoa pode comprar essas fotos e usá-las para qualquer fim. Foi o que aconteceu em 1993, quando a Editora Gráfica Universal do Reino de Deus, comprou as fotos da matéria que fiz para O Dia e publicou no jornal Folha Universal uma matéria com o título "Filhos do Demônio". Milhares de jornais com as fotos de Ricardo, Paula e Tauana foram espalhados pela baixada Fluminense e por outras regiões do estado do Rio. Três anos depois, a mesma editora 
lançou a $13^{\mathrm{a}}$ edição (1996) do livro Orixás, Caboclos e GuiasDeuses ou Demônios", escrito pelo bispo Edir Macedo. Na tiragem de 50 mil exemplares, outra vez a reprodução das fotos da reportagem que fiz: Paula e Ricardo apareceram agora sob a seguinte legenda: 'Essas crianças, por terem sido envolvidas com os Orixás, certamente não terão boas notas na escola e serão filhos-problemas na adolescência' (Macedo, 1996, p. 50). A capa dessa edição comemora 2 milhões de exemplares vendidos" (2012, p.27)

O trecho citado despertou em mim uma revolta e um interesse maior ainda pelo assunto, porém de outra forma; me reconheci como uma criança de terreiro, que tomada por sentimentos confusos da infância, se afastou da religião, assim como inúmeras outras pessoas se afastam. Não por não se identificarem, mas pelo medo criado pela falta de informação e preconceito. Este livro e toda a experiência que me acompanhava no momento me levaram de volta ao terreiro.

As experiências que seguiram, virão com outras Alices, mas cabe dizer aqui que, em novembro de 2013, Mestre Alcides me levou para conhecer o terreiro de umbanda o qual frequenta e cumpre obrigações há mais de vinte anos. Essa foi a primeira vez que pisei em um terreiro de umbanda sem ser acompanhada de minha mãe, sem ser criança de terreiro. 


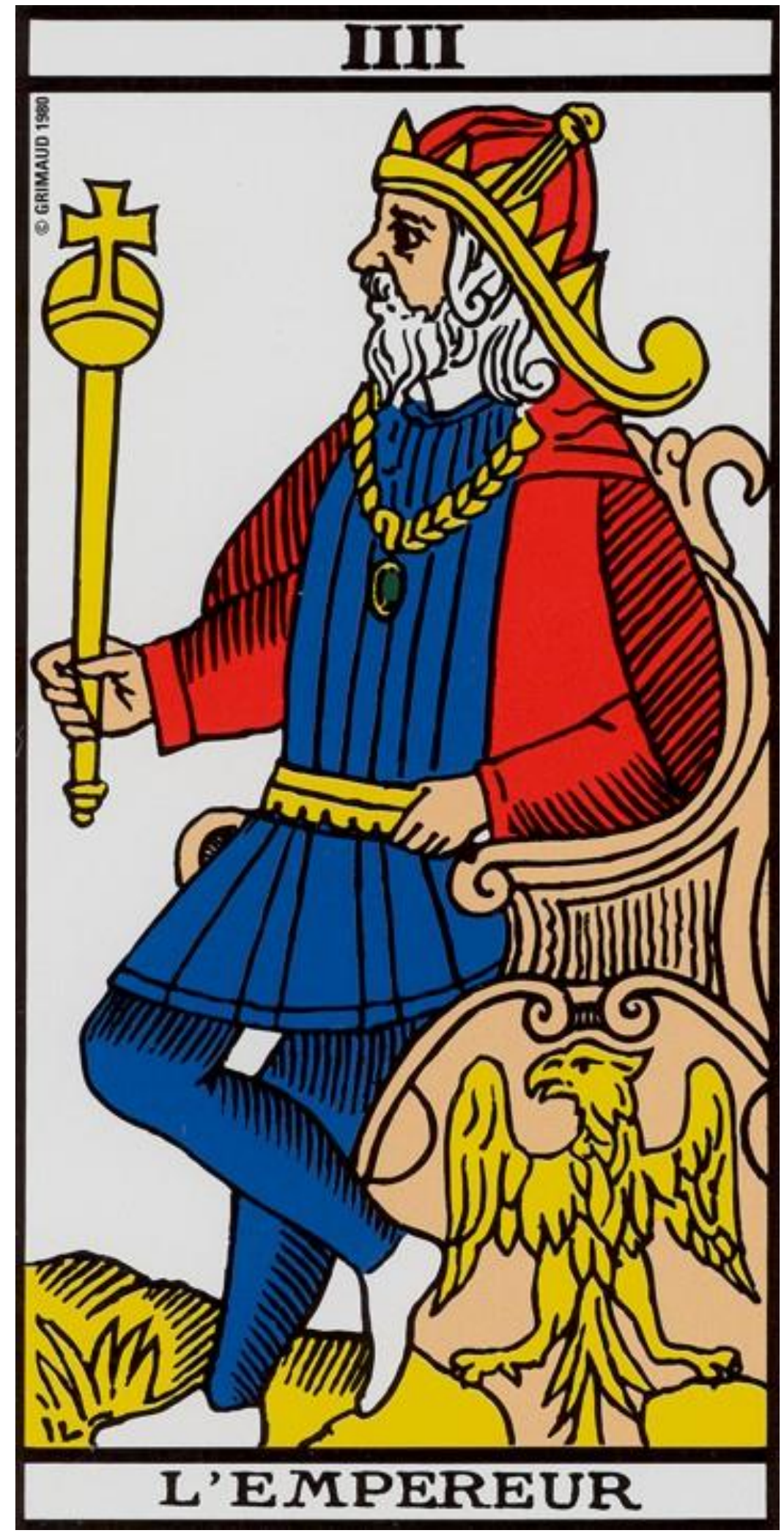




\section{4 - Alice e o mundo atrás do espelho}

Certo dia, Alice chegou mais cedo à caverna. Estava frio $e$ chovendo, os meninos de luz haviam se escondido e Alice estava sozinha perambulando pela floresta. Tudo lhe parecia muito triste e sombrio, restando-lhe apenas a opção de se esconder quietinha em sua morada.

Alice entrou devagar e cuidadosamente, temendo incomodar o dragão. Melhor seria se conseguisse entrar e se acomodar sem lembrar ao dragão que ela também vivia ali, sem tirá-lo de seu mundo de devaneios e sono sem fim.

Curiosamente, neste dia, o dragão a esperava. Sorria com uma assadeira de bolo na mão, usando um avental vermelho e um cigarro que pitava dentro de seu sorriso inebriante. Alice ficou muito confusa, não entendeu a cena que via, mas preferiu não pedir explicações.

O dragão pediu que Alice sentasse, deu a ela um enorme pedaço de bolo com chá. O chá estava amargo, mas era quente o suficiente para acalentar e conquistar o brilho do olhar de Alice. Alice se sentiu querida, como quase nunca se sentia.

O dragão sentou-se a sua frente, ambos iluminados por uma imensa vela amarela que Alice nunca havia notado. Com um pedaço de bolo e uma caneca de chá nas mãos, o dragão começou a contar a Alice uma história cheia de encantos e fadas, como aquelas histórias que os meninos de luz lhe contavam.

Alice observava o jeito como o dragão falava, suas risadas sem interlocução, o olhar perdido num mundo inventado. Alice estava achando tudo muito estranho, mas curiosamente, Alice se sentia confortável na situação. Havia um 
bem-estar, um sentir-se aceita, certa gratidão nos olhos do dragão. Alice nem ouvia mais a história que o dragão contava, ela só queria sentir todo aquele acolhimento.

De manhã, contagiada pelo dragão, Alice subiu em seu dorso e sentiu o vento puxando seus cabelos para trás, tamanha a velocidade com que o dragão voava. Quando o dragão pousou, Alice viu um mundo completamente diferente do seu, onde havia muito mais solidão, muita mesquinhez e palavras desconhecidas... E foi ali que o dragão a deixou.

Alice só se deu conta de que fora abandonada no final do dia, quando as estrelas que deveriam clarear o céu, se apagaram. 


\subsection{Um buraco profundo}

Em 1983, eu e minha mãe saímos da casa da minha avó. Minha mãe resolvera se mudar e morar com o então namorado e futuro marido. Eu tinha apenas seis anos e nenhuma consciência do que aquilo significava. Se compararmos nossa Alice com a de Lewis Carroll, podemos dizer que é este momento em que Alice cai no buraco e começa a se dar conta de sua existência e da responsabilidade que tem sobre sua própria vida.

Daí o sentimento de abandono ao final do dia, a consciência tardia que se deu só na vida adulta, de que muito precocemente fui deixada sob meus próprios cuidados. Poderíamos considerar que esta foi uma "passagem" na vida de Alice, uma mudança de estágio que a levará a ver o mundo com outros olhos, ou, simbolicamente, enxergar um outro mundo. Todos nós passamos por situações internas ou externas que possibilitam o aparecimento de uma mentalidade mais ampla e madura, o que Jung chama de processo de individuação. O processo é individual e por mais que tenhamos problemas semelhantes, a forma de percebê-los e resolvê-los é próprio de cada um (Jung, 2002b).

Esse conto de Alice pode ser um fio que dialoga com os momentos de perda e transformação da vida de Matheus e de Mestre Alcides, momentos difíceis que os colocaram em situações-limite de mudança e amadurecimento.

No relato sobre a vida de Matheus, ele nos conta com muita dor sobre a perda do pai: "Numa das partes mais tristes da minha vida, meu pai ficou doente. Ele tinha uma lojinha, tinha se aposentado. Foi obrigado a se aposentar porque ele se endividou. Ele construiu uma casa e na caixona Federal tinha 
um reajuste mensal, naquela época, chamado correção monetária e os juros eram violentos e ele não conseguia pagar a prestação da casa. Ele teve que sair das lojas Pernambucanas para receber o fundo de garantia para poder pagar as dívidas. Ele fez um acordo. Se ele se aposentasse lá, por tempo normal, ele ia ganhar um prêmio. Ele era um dos vendedores mais atuantes. Quando ele faleceu eu fui fazer inventário, tirar a documentação dele nas Pernambucanas e nos últimos 10 anos que ele trabalhou lá, ele era o primeiro vendedor, o que mais vendia. Ele era muito atencioso com todo mundo, era uma pessoa muito bacana. Por causa da dívida, enfim, uma série de coisas, ele ficou doente, com câncer no intestino e fez várias cirurgias, mas ele não conseguiu, faleceu. Eu tinha 17 anos, parei de estudar um tempo, fui cuidar das coisas da família, minha mãe em depressão profunda e eu tive que cuidar da família. Toquei a lojinha durante uns três anos (...) Minha avó também ficou doente. Morreu minha avó, morreu meu avô, foi assim, em três, quatro anos, morreu meu pai, minha avó e meu avô.”

Mestre Alcides, apesar de ter saído de casa aos 12 anos pela primeira vez para trabalhar em outro estado, não se refere a essa experiência como uma primeira dificuldade que o fez olhar o mundo de outra forma. Para Mestre Alcides, a experiência escolar é que o colocou em necessária "adaptação ao mundo", tal como dito por Jung (2002b). Em suas palavras: “Meu pai, muito contra a vontade, mandava a gente para escola. Para ir para escola, eu tinha que andar, eu e minhas irmãs, duas léguas: são doze quilômetros para ir para escola, mais doze quilômetros para voltar. Eram vinte e quatro quilômetros por dia. Tinha 
que chegar na cidade e entrar na aula sete e meia, a gente tinha que sair quatro e meia da manhã para chegar na cidade às sete horas para entrar na sala de aula às sete e meia. Fazia isso com maior gosto, estudava muito, tirava notas altíssimas porque se tirasse notas baixas, meu pai tirava da escola. Meu pai não dava dinheiro para minha mãe comprar material, caderno, borracha, lápis... Naquela época se escrevia com tinta de tinteiro, nosso material era o de pior qualidade, mesmo assim eu me dediquei ao máximo, tirava as melhores notas. Sofria na época também preconceitos. (...) Mas isso nunca me abalou no sentido de eu me revoltar com isso, eu sempre entendi que esta questão da diferença, do racismo, do preconceito, é uma coisa que existia e existe, sempre vai existir, acho que a gente tem que combater, não aceitar e não acomodar com isso e foi uma das formas que eu achei de combater, ir para escola, entender, e não se conformar com isso e saber todos os momentos que a gente sofre essa questão."

As três histórias de vida se entrelaçam aqui nos primeiros momentos de tensão da vida, aqueles que nos fizeram amadurecer ao lidar com sentimentos como abandono, morte, rejeição, preconceito. Matheus, ao contrário de Alice e Mestre Alcides, cita esse primeiro episódio, no momento de passagem da vida adolescente para a adulta, como seu ritual de passagem. Nas outras duas histórias, as situações de individuação vieram nessa passagem da criança para a vida escolar.

Meus mestres em suas histórias de vida foram exemplos de superação. Matheus, além de mestre, assumiu durante algum tempo um papel de pai em minha vida. Quando engravidei do meu primeiro filho não tive apoio da família e Matheus nunca 
deixou eu me sentir desamparada. Por muitas vezes, o chamei de pai e quando perguntei a ele qual era a relação que ele tinha comigo, foi assim que ele respondeu: "Eu queria te ajudar, eu senti que você estava precisando (...) aí eu fui entendendo mais, mas foi por sentimento, Carla, como se fosse um pai e filho, não sei, uma coisa assim, um sentimento de proteger".

Matheus é humanitário e acolhedor, tem essa característica de protetor e foi para mim uma figura masculina que me permitiu viver a minha fantasia de pai. Nunca tive meu pai perto e esse mestre me ofereceu a possibilidade de ter uma referência positiva de paternidade. Matheus me ensinou que eu podia ser aceita como filha, me permitiu o sentimento de aceitação.

Já Mestre Alcides até hoje me ensina a conquistar o respeito, a me sentir merecedora de respeito e a me respeitar. Com suas histórias de superação, meus mestres puderam me ensinar. O que Gusdorf (2003) chama de "o encontro", o momento em que mestre e aprendiz se identificam e se permitem viver esta relação de troca, de ensino e de aprendizado. 


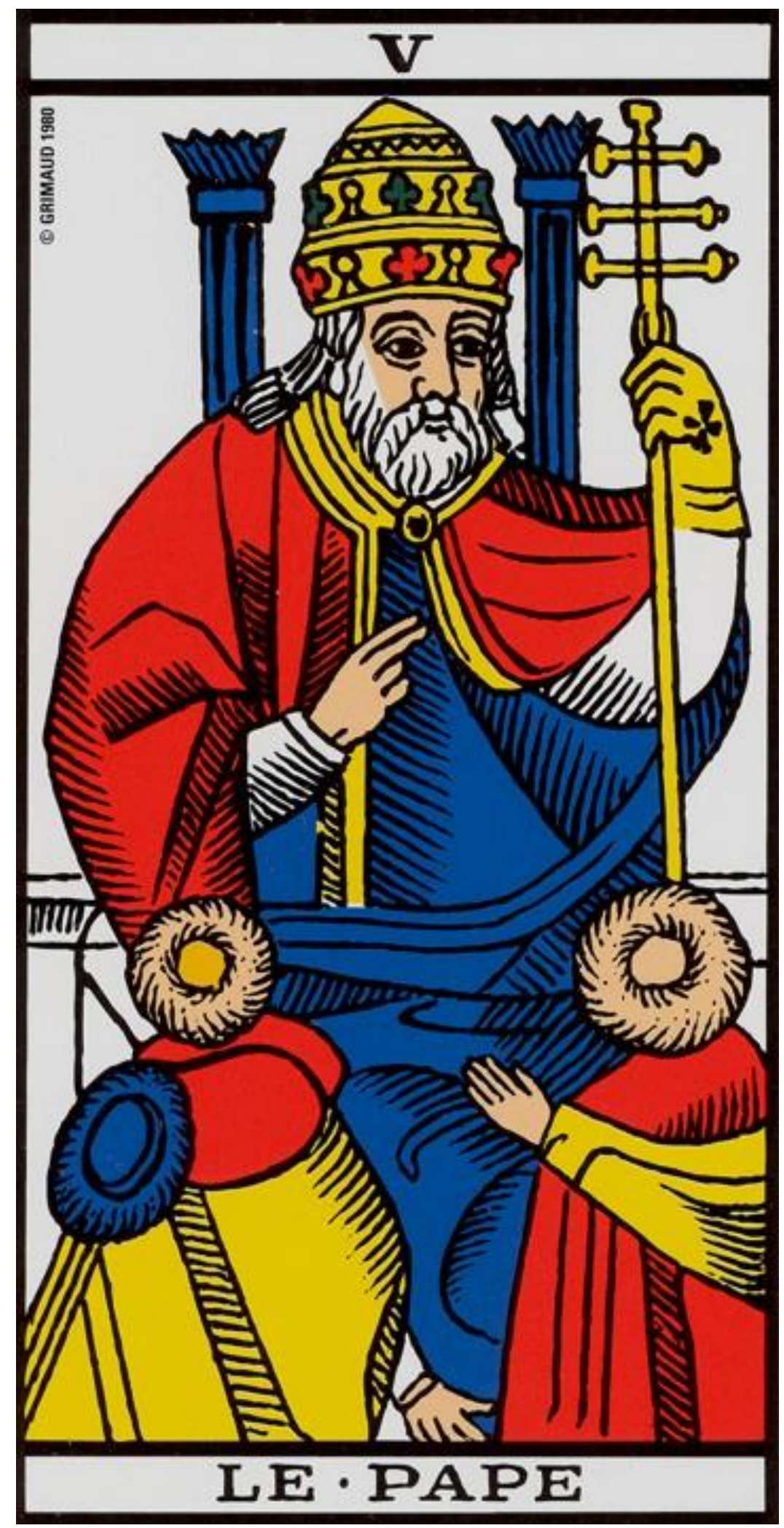




\section{5 - Alice e o encontro com as fadas}

Alice que agora se via sozinha saía para descobrir o mundo. Não era fácil para Alice cuidar de si assim, sem a ajuda de ninguém. Por mais sozinha que fosse, Alice sempre encontrava os meninos de luz, que a distraiam, contavam histórias, levavam Alice para outros mundos.

No lugar onde vivia agora, Alice tinha que se virar. Tinha tempo certo para tudo e era ela que cuidava para esse tempo não se perder, para ela não se atrasar e paras as horas não chegarem antes dela.

No seu abandono, Alice saía andando por aí... Ela não procurava pelos meninos de luz porque sabia que os meninos haviam ficado no seu mundo encantado. Alice saía para descobrir novos caminhos, ver o verde novo das árvores, brincar nos tratores abandonados nos jardins e conhecer outras Alices.

Certo dia, Alice ouviu um som, uma música que a seduzia, a chamava, a encantava. Ela foi seguindo os passos dessa música misteriosa e deu com a cara numa porta bem grande - a entrada de um castelo. Alice, que nem nunca havia visto um castelo, ficou paralisada. Sem ação, Alice tentava sentir a textura da porta e das paredes desse lugar tão maravilhoso. Logo, ouviu vozes de meninas. Meninas que riam e contavam histórias e dançavam... Era tão lindo de ver. Elas se juntavam em grupinhos de quatro ou cinco, se davam as mãos $e$, apesar de tão frageizinhas que eram, ficavam fortes. Alice foi chegando mais perto e seguiu as meninas para dentro do 
castelo. O lugar foi perdendo a importância, o que Alice queria era saber mais daquelas meninas.

Alice ia se escondendo atrás de pilastras e batentes, correndo sorrateira, sem que ninguém a visse. Até que chegou numa imensa sala, toda iluminada pela luz do Sol que entrava pelas enormes janelas abertas. Havia muitas meninas e uma mulher grande e séria, com asas caídas que arrastavam no chão.

De repente, a mulher deu alguns passos para o centro da sala. Deu um sinal para que a música começasse. As meninas ficaram caladas e delicadamente se organizaram em seus lugares. Quando a música começou, as asas daquela mulher se ergueram e se abriram... Eram lindas. Alice respirou fundo $e$ boquiaberta, sentou no chão. Ela já não se preocupava em ser descoberta.

As meninas imitavam aquela deslumbrante mulher e em minutos todas voavam pela imensa sala num voo sincronizado de asas e cores, balanços e pernas... Alice nunca tinha visto nada igual e desejou no fundo de sua alma aprender a voar como aquelas meninas.

- Saia da sala! Aqui não há lugar para meninas sem asas.

Alice fora descoberta! Tentou em todas as línguas explicar que tinha asas, mas que elas só apareciam em ocasiões muito especiais.

Não foi ouvida. Ninguém acreditava que aquela menina tão só podia voar. 


\section{1 - Sobre as sobras ou sobre as peças fora do tabuleiro - desestrutura familiar.}

A saída da casa de minha avó trouxe muitas mudanças para minha vida. Eu que até então era cuidada por ela e por todos naquele quintal, passei a ficar sob os cuidados de uma doméstica. Isto, a princípio, não era de mal algum. Na verdade, a mudança veio na forma de viver. Nós que vivíamos num cortiço passamos a viver num apartamento recém-mobiliado, com uma estrutura que eu só via pela televisão.

Minha mãe sentiu muito orgulho pela sua "conquista". Seu sonho de sair da pobreza havia se realizado e ela podia se regozijar de uma vida confortável e socialmente mais elevada. Eu passei a ter meu quarto, viver com outras pessoas e ter um padrão muito diferente daquele em que vivia.

Ao buscarmos esta passagem em Alice, seria o seu encontro com o castelo. Sendo o castelo a representação simbólica do lugar cercado por muralhas, protegido e inacessível, como colocado por Jung. Mesmo conseguindo entrar no castelo, Alice não fazia parte daquele mundo. Talvez a grande senhora dona de asas grandes e coloridas fosse só uma parte de mim que dizia a mim mesma que aquele não era meu lugar.

Todas essas mudanças trouxeram também um sentimento de valorização, me sentia princesa, me sentia rica. Não sabia que na verdade, havíamos mudado muito pouco economicamente. Porém, rapidamente esta realidade deixou de existir. Meu padrasto foi à falência e minha mãe perdeu o emprego porque engravidou. 
Logo, não tínhamos mais empregada, nem carro do ano, nem restaurantes ou viagens aos finais de semana. Logo, não tinha mais ninguém para cuidar de mim.

Lembro-me de passar as tardes sozinha em casa e por conta dos atrasos no pagamento do transporte escolar, passei a ir andando para a escola. No caminho, passava por um complexo de esportes e lá, tinha aula de balé. Muitas vezes, não ia para casa depois da escola; ia assistir às aulas que eu não podia fazer.

Talvez, esta tenha sido minha primeira grande frustração da vida. Eu tinha só seis ou sete anos e o sonho de ser bailarina. Minha mãe dizia que não podia pagar e, acho, não dava para aquela minha vontade a importância que eu dava. Ver aquelas meninas de rosa, todas lindas, preparadas e tão seriamente envolvidas naquelas aulas, me dava uma vontade enorme de ser como elas. Uma frustração que demorou para sair de dentro de mim, uma vontade que permaneceu em mim até a vida adulta. Estas são as fadas bailarinas de Alice.

E se falamos aqui dos processos, dos afetos, das experiências que nos fizeram ser quem somos, cabe então falar da minha relação com o sentimento de frustração, com minha dificuldade em lidar com a impossibilidade, com minha negação diante da não realização dos meus quereres. Ou simplesmente das questões sociais que nos envolvem desde a infância em processos de exclusão de grupos nos quais não somos aceitos ou dos que não nos permitimos fazer parte.

Neste aspecto, dialogo com Mestre Alcides na sua relação com o espaço escolar e à sua luta com seu pai pela permanência nesse lugar. Mestre Alcides nos relata sua vontade de estudar e construir um outro lugar social, porque desde muito jovem tem 
consciência dos muros que o excluem de outros mundos. No seu relato "Minha mãe me levava para brincar com os filhos do fazendeiro e para brincar com os filhos do fazendeiro, a gente era mais um objeto de brinquedo do que companheiro de brinquedo, entendeu? A gente era mais um brinquedo pros meninos dos fazendeiros do que um companheiro de brincar, então, eu já entendia toda essa problemática, eu tinha uma visão disso e eu virei uma criança rebelde, eu queria ir estudar, eu não queria ir para a roça, e aí eu era muito rechaçado porque todas as crianças tinham que ir para a roça, todas as crianças de todos esses capatazes aí, tinham que ir para roça, $e$ eu falava: 'Eu não quero ir para roça'. Aí, meu pai não tinha jeito, arrumava uma enxadinha, só faltava desenhar no cabo da enxadinha e me dava e eu chegava lá na roça e quebrava o cabo da enxada, aí meu pai ficava muito bravo, para não me bater, ele me mandava para casa. Minha mãe que é analfabeta, que falava: 'Os meninos têm que estudar'

Em seu relato, Mestre Alcides mostra sua dificuldade em pertencer ao espaço a ele negado, que por insistência sua e de sua mãe, fora conquistado. É evidente que sua luta é incomparável a minha questão, que por mais legítima que fosse, não seria para mim, um "andaime" social. Porém, aquele sonho de ser bailarina, estava repleto de valores sociais agregados ao "ser menina" no mundo dos brancos.

Numa análise arquetípica, a escolha das fadas como representação simbólica deste "desejo/identidade", traz a figura imaginária da realização de desejos, da magia, da transcendência. 
"Mestra da magia, a fada simboliza os poderes paranormais do espírito ou as capacidades mágicas da imaginação. Ela opera as mais extraordinárias transformações e, num instante, satisfaz ou decepciona os mais ambiciosos desejos. Talvez por isso ela represente a capacidade que o homem possui para construir, na imaginação, os projetos que não pode realizar. (Chevalier e Gheerbrant, 2005, p. 415).

A escolha do arquétipo fada traz em sua subjetividade a vontade de realização perante a impossibilidade, o desejo velado de que uma intervenção mágica trouxesse vitória na batalha contra o dragão, na possibilidade de Alice tornar-se encantada novamente. $\mathrm{O}$ arquétipo da fada aparece com muita frequência em mitos e lendas e tem sido associada à figura da bailarina em estereótipos sociais. Daí, que ao acessar essa figura mítica, também acessamos as imagens e discursos que nos são colocados no mundo em que vivemos. Arquétipo, fantasia e o meio social se misturam e nos fazem buscar mais do que formas de representar o inconsciente, mas também de atender demandas de modelos sociais impostos (Correia, 2010).

Mestre Alcides não cita símbolos, nem arquétipos em eu depoimento. Mas é implícito em seu discurso a luta e o desejo de pertencimento a um espaço social que traz em sua representação simbólica a ascensão a um mundo de privilégios, de respeito e poder: o espaço escolar, mas não enquanto espaço do aprender; mas como espaço de pertencer ao mundo daqueles que tem poder sobre seus semelhantes.

Gilberto Freyre, em "Casa grande e senzala”, traz um pouco desta história da educação do Brasil, da educação dos meninos e moleques, do espaço negado aos negros. Das misturas de infância de negros e brancos, da segregação dessas crianças na idade escolar. Se crescerem juntos brincando no barro da terra, 
no leito do rio, na copa da árvore, logo serão segregados em dois grupos: dos que merecem os bancos da escola e dos que merecem o trabalho na roça e no engenho.

Ainda nas brincadeiras com os brancos, Mestre Alcides já se via objeto. O sadismo do uso e desuso do negro que fez parte de nossa história e desde os idos da colônia, separou em dois mundos as crianças de um mesmo quintal.

\begin{abstract}
“A verdade, porém, é que nós é que fomos os sadistas; o elemento ativo na corrupção da vida e da família; de moleques e mulatas o elemento passivo. Na realidade, nem o branco nem o negro agiram por si, muito menos como raça, ou sob ação preponderante do clima, nas relações do sexo e de classe que se desenvolveram entre senhores e escravos do Brasil. Exprimiu-se nestas relações o espírito do sistema econômico que nos dividiu, como um deus poderoso, em senhores e escravos. Dele se deriva toda a exagerada tendência para o sadismo característico do brasileiro, nascido e criado em casa-grande, principalmente em engenho (Freyre, 2006, p. 462)"
\end{abstract}

Mestre Alcides se empoderou do arquétipo ocidental do "Doutor”, do "sábio", não aquele de sua ancestralidade, aquele que ele próprio resgata em sua trajetória de vida. Mas aquele dos livros, das letras, dos diplomas. O legado da tradição ocidental na formação do nosso país, como citado por Ferreira-Santos:

"Herança lusitana e cartorária, uma tradição legalista, cuidadosamente cultivada e propalada pelos 'doutores'. Do início da colonização até às portas da República, o imaginário social era, solidamente, amparado sobre a necessidade de educação dos filhos, sendo o primeiro um 'doutor' (entenda-se, um advogado); o seguinte, um soldado; e sucessivamente, filhos com ocupações liberais ou no funcionalismo público, até o caçula, que deveria ser, então, padre; atendendo, desta forma, às destinações patriarcais das leis, da economia, do Estado e da religião”. (1993, p.8) 
A fada e sua magia serviriam para mim e Mestre Alcides como a representação do contato com um mundo novo e inacessível:

"Reação de espanto face à inapreensibilidade do significado do acontecimento, reflexo do deslumbramento diante de um inexplicável incorporado àquele universo, estabelecendo uma relação de estranhamento e de cumplicidade" (Le Goff, 1990, p. 18).

Um querer-se parte por encantamento, por estranhamento, por impossibilidade, um querer da transcendência.

Não caberão encontros entre mestres em todas as Alices. Não encontrei um diálogo entre esse conto e a história de vida de Matheus. O pouco que cita sobre este sentimento de "não pertencimento" vem em laços com Alices futuras. 


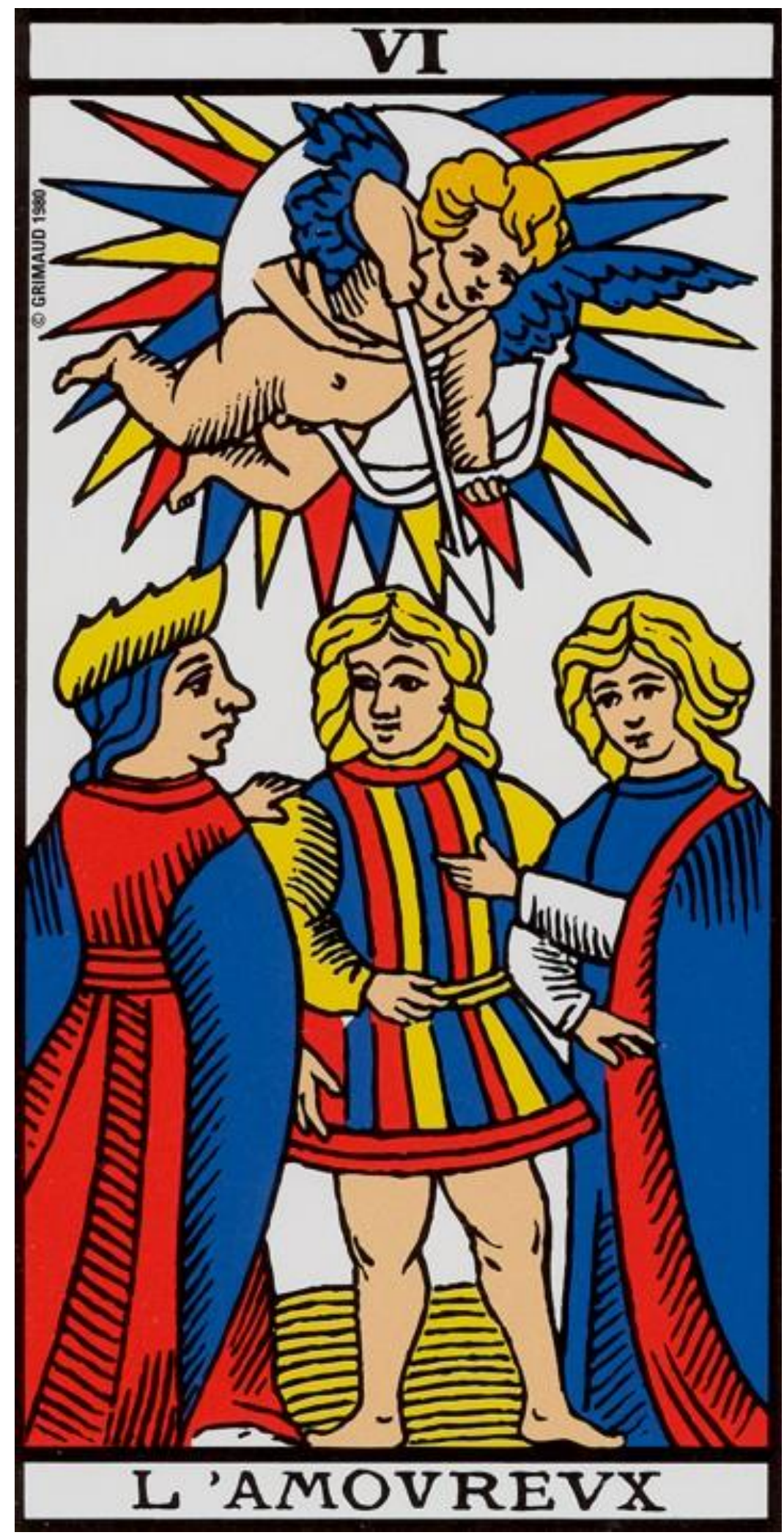




\section{6 - Alice e o homem sem face}

Alice levava a vida de maneira leve, aprenderá desde pequena a lidar com o ódio e a tristeza do dragão. Apesar de se sentir muito só, Alice criava mil histórias em sua cabeça e fingia estar sempre cercada por meninos de luz. Alice descobriu os livros e, sempre que podia, lia. Era como se um menino de luz estive lhe narrando um conto e a levando para lugares mágicos e encantados.

Certa vez, o dragão veio visitar Alice e a levou para um lugar escuro. $O$ dragão lhe prometeu que aquele era um lugar especial, onde haviam seres luminosos e que de tanta luz, preferiam viver na escuridão.

Alice não entendeu nada daquele assunto. Alice conhecia bem meninos de luz e sabia que eles fugiam de medo da escuridão. Mas se o dragão lhe prometera, como não acreditar?

A escuridão escondia um pântano lodoso e fétido. Alice não entendia porque tinha que andar sujando seus sapatos limpinhos, suas meias e seu vestido. O pé prendia no chão a cada passo e ela não conseguia andar sem apoio. Ora colocava a mão em galhos e troncos que a machucavam, porque eram cheios de espinho; ora escorregava e caia sentada na lama.

O dragão não entrou com Alice e foi por prova de amor, que Alice enfrentou a escuridão. Ela não tinha medo porque em sua vida o que lhe dava medo era a ira do dragão, porém não se sentia confortável na situação.

Ouviu uma voz, uma voz de homem, uma voz suave de homem. Olhou para traz e viu dois pontos azuis. Pensou que eram vaga-lumes mágicos. Foi até eles. 
Não era possível ver o rosto do homem dono dos olhos azuis que brilhavam e enganaram Alice. O homem vestia uma capa comprida e preta que, na escuridão, não deixava entrar uma fresta de luz para iluminar seu semblante. Alice só conseguia ver dois pontos de luz azul dentro de um capuz.

O homem, que não disse nada depois da aproximação de Alice, tomou-a pela mão e a conduziu pelo pântano. Alice confiou... confiou no dragão e confiou no homem de olhos azuis e sem rosto.

Quando acordou, Alice estava do lado de fora do pântano. A luz do Sol machucava seus olhos. Ela estava toda suja, caída perto de uma pedra. Ela não se lembrava de nada, mas uma cicatriz havia ficado em sua mão... Para sempre Alice se lembraria do pântano, da escuridão e do homem sem face. Alice nunca perdoou o dragão. 


\section{1 - Os caminhos, às vezes, nos trazem solidão - sobre os abusos e a falta de proteção}

Esta Alice é das mais especiais, das mais duras e difíceis também. Neste item não faremos menção à vida dos mestres. Será uma reflexão solitária sobre essa passagem da minha vida. Momento que não durou muito, mas que deixou marcas profundas. Marcas dessas que ajudam a sedimentar estigmas e chagas sociais.

A crise financeira em casa foi ficando mais séria e, de repente, descobri que minha mãe estava grávida e desempregada por conta da gestação. Começa, então, a fase mais difícil da minha vida e que durou até eu sair de casa aos 18 anos.

Além da demissão da minha mãe, houve a falência da empresa do meu padrasto. Aquela vida boa de apartamento com tudo novo, empregada e comida gourmet havia se transformado numa casa endividada, com dois desempregados e desiludidos vivendo juntos.

Minha mãe começou aí sua crise existencial... A cruz que ela carrega com ela até hoje das escolhas malfeitas na vida. Se morar no "apartamento" era sinônimo de prosperidade, sucesso e riqueza, agora era só um atestado de burrice ou de ilusão.

A vida no apartamento foi ficando cada vez mais difícil e um dia nos mudamos. Saímos do apartamento sem pagar e fomos morar numa casa na periferia.

Lembro que um dia estávamos na casa do filho do meu padrasto, acompanhando a situação de saúde do então presidente eleito Tancredo Neves e na TV se noticiava um rebuliço geral pelas eleições diretas... Deu-se a notícia de sua 
morte. Fomos embora num clima meio triste que eu não entendia. No dia seguinte, de manhã, minha mãe não estava em casa. Meu padrasto me acordou para a escola e disse que minha mãe tinha ganhado "neném" e que logo voltaria.

Eu lembro quando vi minha irmã pela primeira vez. Minha mãe estava acabada, mal conseguia andar, toda enfaixada e aquele bebezinho tão pequenininho ali do lado dela na cama.

Minha mãe não trabalhava mais, era "dona do lar" e meu padrasto investia tudo o que podia em sua nova empresa e trabalhando como fotógrafo em escolas. Ele tirava fotos como aquelas em que o aluno fica sentado atrás de uma mesa, ao lado da bandeira nacional. Um cartão trazia duas fotos, a outra, era da turma da sala com a professora.

Foi nessa casa que se deu um dos episódios mais traumáticos da minha vida. Meu padrasto era muito cheio de amigos, em geral, gente com posses. Muitos deles frequentavam a casa e lembro-me de dois que eu gostava muito. Um que era sempre muito gentil e me enchia de presentes.

E tinha outro, um estrangeiro, que tinha sotaque meio espanhol. Era alto, olhos claros, pele meio vermelha. Eu o achava bonito. Ele era dono de uma loja de revelação fotográfica e era sócio nos negócios escusos do meu padrasto. Seu nome era Hermínio. Vez ou outra ele ia em casa ou íamos à casa dele. Ele era um homem bem violento, que batia na mulher e espancava o filho, Carlinhos.

Esse sujeito começou a frequentar bastante a casa e passou a dormir lá porque havia se mudado para Minas Gerais. Como ainda tinha trabalho em São Paulo, ficava hospedado em nossa casa. Porém, em nossa casa havia apenas dois quartos. No 
quarto da minha mãe, dormia o casal e minha irmã; no meu quarto, eu dormia sozinha. Toda vez que tinha visita, eu era a anfitriã.

Aquele homem, amigo da família e sócio nos negócios, passou a abusar de mim. Eu tinha oito ou nove anos e me sentia invadida, ao mesmo tempo não sabia o que fazer porque não sabia se aquilo era errado ou se ele fazia algo para me agradar e eu ficava ofendida. O fato é que a situação começou a me incomodar muito e um dia, no café da manhã, falei com a maior naturalidade sobre a situação.

Minha mãe e meu padrasto ficaram paralisados, em silêncio e sem saber o que fazer. Em seguida, alguém disse que não era possível, que eu devia estar enganada, que não podia ser verdade. Prometeram que haveria uma conversa de esclarecimento e que a situação seria resolvida.

Eu não sei se eles conversaram, sei que ele continuou frequentando a casa e eu saía do meu quarto, quando ele estava lá. Certo dia, no início das férias, para mostrar para mim como eu estava enganada e que ele era um homem bom, minha mãe me colocou em seu carro para que ele me levasse até Minas Gerais. Ela chegaria dois dias depois. Chegando antes, eu teria mais tempo para aproveitar a fazenda e as férias.

Foram horas de terror, quase um dia inteiro passando muito medo ao lado daquele homem no carro. Toda vez que ele parava para qualquer coisa na estrada, eu segurava firme no cinto de segurança, com medo que ele pedisse para eu descer ou fizesse algum mal para mim. Na minha imaginação, ele poderia estar com raiva por eu o ter denunciado. Quando chegamos em Minas, eu caí de cama com uma febre de 40 graus. O pessoal da 
casa dizia que era saudade da minha mãe. Foi minha terapeuta, quase 30 anos depois, que explicou que a febre foi de medo, de fraqueza por ter sido tão forte e aguentado a longa viagem.

Foi a primeira vez que falei sobre isso, depois de ter tido uma crise de pânico num teleférico, onde eu não me mexia com medo de cair e morrer... Foi falando sobre esta situação que me veio a lembrança daquela viagem para Minas... Vivi mais uma vez aquele horror, como medida terapêutica de me livrar da dor... da dor que até hoje dói.

Foram marcos que mudaram minha forma de estar no mundo: a infelicidade de minha mãe como trajetória de vida, o nascimento da minha irmã e o abuso. Situações onde me vi mais sozinha, mais desamparada e ao mesmo tempo mais responsável pelo que se passava do lado de dentro e de fora de mim.

A metáfora que utilizo no conto de Alice é a do homem sem face, talvez porque não fosse possível dar um nome a todo este conjunto de elementos. Eram muitas coisas e eu muito pequena sem entender exatamente como tudo aquilo me tocava internamente. São os nossos monstros sem nome, com quem temos que aprender a conviver ao longo da vida, nomear e respeitar enquanto partes constituintes daquilo que somos. São esses encontros a que chamo de solidão. Sobre a solidão, Bachelard (2009), nos diz:

"Quando na solidão, há devaneios tão profundos, devaneios que nos ajudam a descer tão profundamente em nós mesmos que nos desembaraçam da nossa história. Libertam-nos do nosso nome. Devolvem-nos, essas solidões de hoje, as solidões primeiras. Essas solidões primeiras, essas solidões de criança, deixam em certas almas marcas indeléveis. Toda vida é sensibilizada para o devaneio poético, para um devaneio que sabe o preço da solidão. A infância conhece a infelicidade pelos homens. (...) Como não sentir que há comunicação entre a nossa solidão de sonhador e as solidões da infância?” (p. 94) 
Como já mencionado, a intenção não é de análise psicológica ou psicanalítica. Nosso olhar é sempre em direção à uma "poético-análise", esta que, segundo Bachelard, deve nos conduzir ao campo do imaginário:

“A memória é um campo de ruínas psicológicas, um amontoado de recordações. Toda nossa infância está por ser reimaginada. Ao reimaginá-la, temos a possibilidade de reencontrá-la na própria vida dos nossos devaneios de criança solitária” (p. 94)

Sobre a poesia que tornou lembranças em imagem, podemos buscar um significado simbólico para essa solidão acompanhada que Alice vive no passeio no pântano, da sujeira no corpo de Alice, da marca-cicatriz, do homem sem face e sem luz.

São símbolos que retratam a escuridão, a inocência, a permanência num espaço-lembrança; “da continuidade dos devaneios da grande infância e dos devaneios do poeta”, nos diz Bachelard. Dessa comunicação entre a solidão de hoje e a solidão infantil. Dos momentos em que andamos a sós, quando em fantasia deveríamos estar acompanhados.

Do ponto de vista mitológico, o homem sem face, cuja aparência se aproxima à imagem da morte, lembra Hades (deus do mundo inferior e dos mortos), e a experiência de Alice, o rapto de Perséfone. Jung (2002b) explica este símbolo como uma representação de uma forma negativa de animus

“(...) que afasta a mulher de qualquer relacionamento humano e, sobretudo, de qualquer contato com os homens. Personifica uma espécie de 'casulo' dos pensamentos oníricos, dos desejos e julgamentos que definem as situações como elas "deveriam ser", afastando a mulher de toda a realidade da vida” (p. 191)

Dos devaneios da infância a esta personificação simbólica, a este devaneio adulto, encontro as respostas para tantos "estar 
só”, para tantos "querer-me só”, para tanta busca pelo inalcançável nos caminhos trilhados no vivido.

Nesta Alice não há encontros com mestres. Aqui, Alice andou só. 


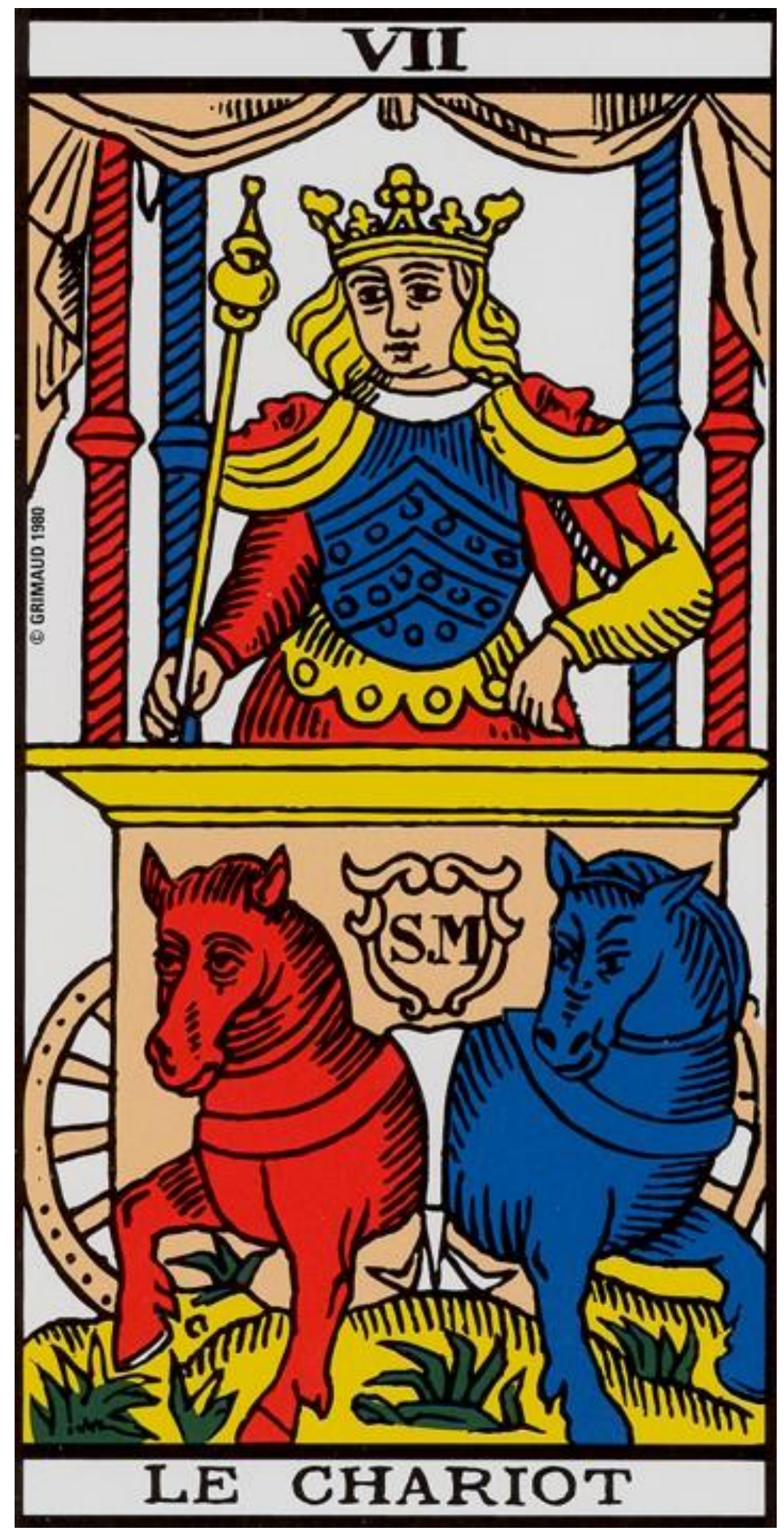




\section{7 - $O$ dragão, os sapos e a solidão}

Apesar de ter abandonado Alice, o dragão sempre estava por perto. Alice não sabia se ele havia se mudado com ela ou se apenas a rondava, mas o fato é que Alice, por vezes, se via na sombra do dragão, como se ele apenas voasse sobre ela para lhe aterrorizar, para lhe lembrar de sua existência, para que ela não perdesse o medo.

Alice ia vivendo, aprendendo a se cuidar cada vez melhor, seguia sem confiar em quase ninguém, sem se aproximar muito para não se machucar. O que Alice gostava era de viajar em histórias fantásticas que ela ouvia aqui e ali ou que ela inventava em sua cabeça. Às vezes, o mundo era tão sem graça, que ela o bordava todo de linhas coloridas... Colocava uma música aqui, um arco-íris ali, um disco voador que a raptava e a levava para as estrelas. Alice sonhava, mas sonhava só quando estava acordada. Quando dormia, Alice tinha pesadelos e, por isso, Alice dormia muito pouco.

Pela manhã, Alice costumava visitar o lago dos sapos... Ela achava muito divertido! Tinha um montão de sapos todos iguais, que cantavam, pulavam, coaxavam... Era uma barulheira. Alice, que não era sapo, não conseguia entrar para a turma, mas adorava papear com um e outro. Alice queria era descobrir os sapos... saber o que se passava em suas pequenas cabeças achatadas. Apesar de adorar aquele lago, Alice sabia que nunca conseguiria agir como eles e que aquele não era o mundo dela. Por isso, às vezes, ficava triste desejando ser um sapo ou, simplesmente, achar um céu de meninas-borboletas. 
Toda a sozinhes de Alice era acompanhada de muito trabalho... O dragão, quando a deixou, deixou também tarefas para que ela cumprisse. Como os trabalhos de Hércules, Alice havia ganhado 12 tarefas e a promessa da liberdade. Todos os dias eram dias de cumprir tarefas e Alice as fazia com a máxima dedicação, para que saíssem perfeitas e ela tivesse a aprovação do dragão. Alice pensava que se cumprisse tudo que lhe fora pedido, poderia ter de volta o seu mundo de magia e ganhar o perdão do dragão.

Não houve um dia em que tivesse tido sucesso. O dragão nunca aprovou nada do que Alice fazia. 


\section{1 - Andando sob as sombras - a imagem obscura do feminino}

Depois de viver o abandono, Alice passa a viver na sombra do dragão, que a aterroriza e a segue em suas aventuras. Este conto de Alice é a dor da cicatriz da solidão da infância retratada no conto anterior.

Mais uma vez, deparei-me com uma lógica simbólica na sucessão dos contos de Alice. Sem saber sobre a relação do animus negativo e da forma como passei a estar no mundo, Jung e Bachelard trazem à luz os processos envolvidos na relação que passo a construir com o feminino.

No início da escrita, quando Alice era ainda só uma forma de contar em metáforas algumas passagens marcantes da minha vida e quando ainda não havia sobre ela nenhuma análise, discutimos sobre a representação simbólica do dragão nos contos de Alice. O dragão é um elemento fantástico presente em Alice, que a princípio, escolhi como personificação da relação com o materno na infância. Porém, há muito mais que isso e essa escolha inconsciente mostrou apenas o quanto os mitos estão ainda em nosso imaginário e como recorri a este para representar de maneira simbólica minha relação com o feminino.

"Criaturas fantásticas, que desafiam a classificação normal, aparecem em todas as mitologias. A maioria é composta de partes de animais diferentes ou híbridos de homens e animais. Essas criaturas não são necessariamente mal-intencionadas, mas a maior parcela tem poderes mágicos. O dragão, talvez, seja o exemplo mais conhecido. Originários da Mesopotâmia, as histórias dessa fera mítica espalharam-se pela Grécia antiga, além da China e Japão. Na Ásia, o dragão tornou-se uma criatura auspiciosa, fonte de boa sorte e símbolo real. Na Grécia, porém, tornou-se mais monstruosa, algo que os heróis precisavam combater" (Dell, 2014, p.244) 
O dragão de Alice trazia essas características ambíguas de bem e mal, de sorte e azar, de sombra e de luz.

Jung menciona o dragão como um símbolo composto que representa a "força da transcendência, pela qual a consciência subterrânea da cobra, ao passar pela realidade terrena, vai atingir no seu voo uma realidade sobre-humana ou transpessoal" (2002b p. 156). A cobra, símbolo de fertilidade. As asas que alçam voo, a transcendência, os atributos de pássaro. Um símbolo que pode corresponder a Hermes na mitologia grega ou a Exú, na mitologia iorubá. Mitos que representam além da fertilidade e o princípio feminino, o rompimento de limites e a abertura de caminhos para novos mundos.

Neste conto de Alice, a dualidade presente no símbolo do dragão é quebrada. Alice passa a viver em sua sombra. Não há mais a presença física do dragão, apenas seu lado obscuro.

Retomando a fala de Jung sobre o afastamento do relacionamento humano e sobre os devaneios e fantasias que tomam o lugar da realidade: "Alice ia vivendo, aprendendo a se cuidar cada vez melhor, seguia sem confiar em quase ninguém, sem se aproximar muito para não se machucar. O que Alice gostava era de viajar em histórias fantásticas que ela ouvia aqui e ali ou que ela inventava em sua cabeça."

$\mathrm{O}$ que Alice fazia para fugir da realidade, era sonhar. " $\mathrm{Na}$ nossa infância, o devaneio nos dava liberdade”, nos diz o mestre Bachelard: "Quando sonhava em sua solidão, a criança conhecia uma existência sem limites. Seu devaneio não era simplesmente um devaneio de fuga. Era um devaneio de alçar voo." (2009, p. 94). 
Assim como Alice, eu seguia vivendo mais de fantasias do que de realidades, sempre procurando aprender a viver da melhor forma sozinha e buscando em mim recursos para conhecer outros mundos e alcançar a liberdade.

\section{2 - Caixa de paredes brancas e cabeças achatadas - a escola}

Este conto de Alice nos fala ainda sobre o "lago dos sapos de cabeças achatadas”, minha metáfora para escola. Lá nunca foi o lugar do qual me senti parte.

Em 1987 mudei para a praia e fui matriculada em uma escola católica recém-inaugurada, dirigida por freiras.. O colégio havia aberto suas portas um ano antes de eu começar a frequentar. A mensalidade ainda era acessível e seu público não era tão elitizado. Tinha de tudo - da filha do prefeito da cidade até crianças que moravam na favela que circundava a escola.

Lembro-me do primeiro dia nessa escola, foi muito especial. O uniforme impecável, um monte de livros e todo material (cadernos, livros e agenda) deveria ser encapado com papel pardo e plástico. Tudo muito organizado. O uniforme era marrom, tudo marrom, até o tênis e as meias.

Eu nunca fui a melhor aluna da sala. Entrei no Colégio Santa Maria na quarta série e deste ano até a sétima série eu era uma aluna quase autista. Estava sempre no meu mundo. Nunca fui uma menina de ter turmas, eu falava com todo mundo. Ora estava com um grupinho, ora com outro; mas fato é que eu gostava mesmo era de vadiar. Era como se eu vivesse sozinha, só 
experimentando as pessoas... Vivia assim, dona do meu mundo e sempre visitando outros mundos.

Aqui os encontros com os mestres são notáveis. Penso que a escola, seja ela qual for, não é mesmo um espaço de pertencimento. Mestre Alcides nos relata sua experiência traumática com a escola, a questão do racismo, da exclusão, do preconceito "porque na escola, não existia escola particular, naquela época era escola pública para todo mundo, então na minha sala, estudava o filho do prefeito, do vereador, do promotor, do juiz e todo mundo, e essas crianças não nos aceitavam junto, na classe. Eles falavam: 'Ah, tá fedendo preto nessa sala, tá cheirando preto na escola', não sei o quê, as professoras também eram coniventes com isso. Eu já entendia isso, eu já resolvia isso com as crianças, que eu era menino que já brigava, que já batia. Eu já não aceitava isso e por causa disso eu ficava de castigo. Eu fui discriminado, fui chamado de preto fedido. Eu batia no menino, aí a aula terminava às onze e meia, eu ficava até meio-dia no porão, para dar tempo do menino ir embora para casa, quando eu saía não tinha mais ninguém na escola”.

Já Matheus em seu relato: "Olha, para mim foi meio traumático a escola! Porque eu tinha uma vida muito com a minha família e foi a primeira experiência de sair dali de perto da minha mãe, primeira experiência de ficar longe dela, de ficar um tempo fora com grupos diferentes de pessoas, regras... Tinha que seguir umas regras que não tinha (em casa), era diferente. Eu senti um impacto nos primeiros dias, eu senti um peso. Eu fiquei com dor de barriga, essas coisas e tal”. 
Neste conto de Alice encontramos o "lago dos sapos". O lugar que Alice gosta de frequentar pelo bizarro do ajuntamento de sapos. Alice acha engraçado vê-los todos coaxando, convivendo e o que a chama a atenção, são suas "cabeças achatadas". Foi assim, que me referi à escola.

Gostava muito de frequentar a escola, era o lugar que me permitia não estar em casa. Apesar do gosto pelo ir, não conseguia compreender o que de fato a escola devia representar em minha vida, ou mesmo, como eu deveria estar neste lugar. Não me identificava com as atividades, com o espaço, com as pessoas. Não entendia o que os professores queriam, nem mesmo o que explicavam. Achava distante aquele lugar onde estavam os alunos nota dez. Não conseguia me inserir. Assim, vivia observando de longe tudo que acontecia. Eu era a "antropóloga em Marte"... Alguém que havia chegado de "tão distante".

Ao analisar o conto, penso que era esta mesma a relação que desenvolvi no espaço escolar. Eu era a estrangeira, que com olhar apurado, me divertia com os convívios alheios, sofria com as cobranças incompreendidas, burlava regras sem saber que as regras existiam. Experiência que me trouxe muito conhecimento, principalmente no fazer-me educadora.

A escola é para todos uma lembrança inesquecível, como dito por Gusdorf;

"Dentre as recordações privilegiadas que todo homem conserva de sua própria vida - recordações de família, de amor, de guerra, de caça -, as recordações escolares constituem uma categoria particularmente importante. Cada um de nós conserva imagens inesquecíveis do início da vida escolar e da lenta odisseia pedagógica a que se deve o desenvolvimento do nosso pensamento e, em grande parte, a formação da nossa personalidade. Mesmo que o conteúdo do ensino tenha se 
perdido, ou seja, que o homem tenha desaprendido o que a criança aprendeu, o clima da sua vida escolar continua presente nele: a aula, o recreio, os exercícios, os jogos, os colegas." (Gusdorf, 2003, p.01)

Para mim e meus mestres, uma lembrança ruim, mas que sem dúvida nos influenciou na maneira de pensar e de viver. Como não falar da escola numa tese sobre educação, sobre a busca da compreensão dos fenômenos presentes nos processos formativos e sobre a busca da poesia neste caminhar sobre a construção do eu?

Para esta discussão, trago uma referência que gosto muito e que muito dialoga com esta questão: “Cuidado, Escola!" (Harper et al., 1991). De que escola estamos falando?

"Imediatamente depois do maternal a criança é 'parafusada' numa cadeira dura para estudar palavrório durante horas e horas.

Será por acaso que a criança em desenvolvimento, essa força da natureza, essa exploradora aventurosa, é mantida imóvel, petrificada, confinada, reduzida à contemplação das paredes, enquanto o sol brilha lá fora, obrigada a prender a bexiga e os intestinos, 6 horas por dia, exceto alguns minutos de recreio, durante sete anos ou mais?

Haverá maneira melhor de aprender a submissão?

Isso penetra por músculos, sentidos, tripas, nervos e neurônios... Trata-se de uma verdadeira lição de totalitarismo. A posição sentada é reconhecidamente nefasta para a postura e para a circulação e, no entanto, eis nosso homem ocidental com problemas de coluna, as veias esclerosadas, os pulmões retraídos, hemorroidas e nádegas achatadas... Faz um século que vemos as crianças arrastando os pés embaixo das carteiras, entornando o corpo e pulando como rãs quando a sineta bate (sem falar nos 20\% de escolioses). Esse tipo de manifestação é atribuído à turbulência infantil: nunca à imobilidade insuportável imposta às crianças - a culpa é sempre da própria vítima.

Não, não é um acaso. É um plano. Um plano desconhecido para os que o cumprem. Trata-se de domar. Domesticar fisicamente essa máquina fantástica de desejos e prazeres que é a criança.” (Harper et al., 1991, p.47) 
Não, não foi acaso e nem coincidência. Eu e meus mestres passamos por essa escola. Ela estava geograficamente distante, mas foi esta a escola que frequentamos. Nós, crianças de quintal, crianças crescidas livres, cuidadas por muitos. Nós, assim como qualquer brasileirinho que foi a essa escola, vínhamos de misturas de culturas, de cores, de classes, de histórias e fomos todos obrigados a aprender a falar numa só língua as mesmas gramáticas e aritméticas que nos foram impostas.

Cada um de nós com sua particularidade, Mestre Alcides lidava com o racismo, com a marca da sua cor estampada na pele, com a história dos seus ancestrais escravizados e pelos anos em que foi obrigado a aceitar que o seu lugar era outro, qualquer outro fora da caixa de concreto de paredes brancas e meninos educados. Matheus, apesar de lidar com a situação escolar desde a mais tenra infância, era menino de caçar passarinhos, subir em árvores, criar gavião. Eu era a menina do cortiço, criada nos quintais das pequenas casas que juntas formavam uma pequena comunidade.

Como tanta diversidade, numa só caixa?

“(...) as crianças dos meios populares sentem grande estranheza diante da linguagem, normas e valores da escola, que são totalmente diferentes daqueles a que estão habituadas. Elas se sentirão mais inferiorizadas pelo fato de não poderem trazer para a escola sua maneira de falar e sua experiência na família e no bairro menos favorecido. Elas se sentirão perdidas diante da falta de sentido e utilidade imediata dos exercícios escolares, confusas pelo lado artificial das situações vividas em sala de aula" (Harper et al., 1991, p.75)

A escola não havia sido pensada para nós. Ela pertencia a outros e foi por isso, que permanecer neste espaço foi para nós uma luta de adaptação. Todo o conhecimento que tínhamos, de aprender com as próprias descobertas, de ser responsabilidade 
de todos os adultos que nos rodeavam, da experiência com o trabalho, todas estas vivências adquiridas, na escola não tinham valor nenhum.

Assim, fomos sobrevivendo até vencer essa fase. Nenhum de nós conseguiu se submeter. Ao ler os relatos das histórias de vida, veremos ao longo do texto como cada um de nós foi transformando a experiência do aprender em algo mais prazeroso e em espaço de pertencimento. 


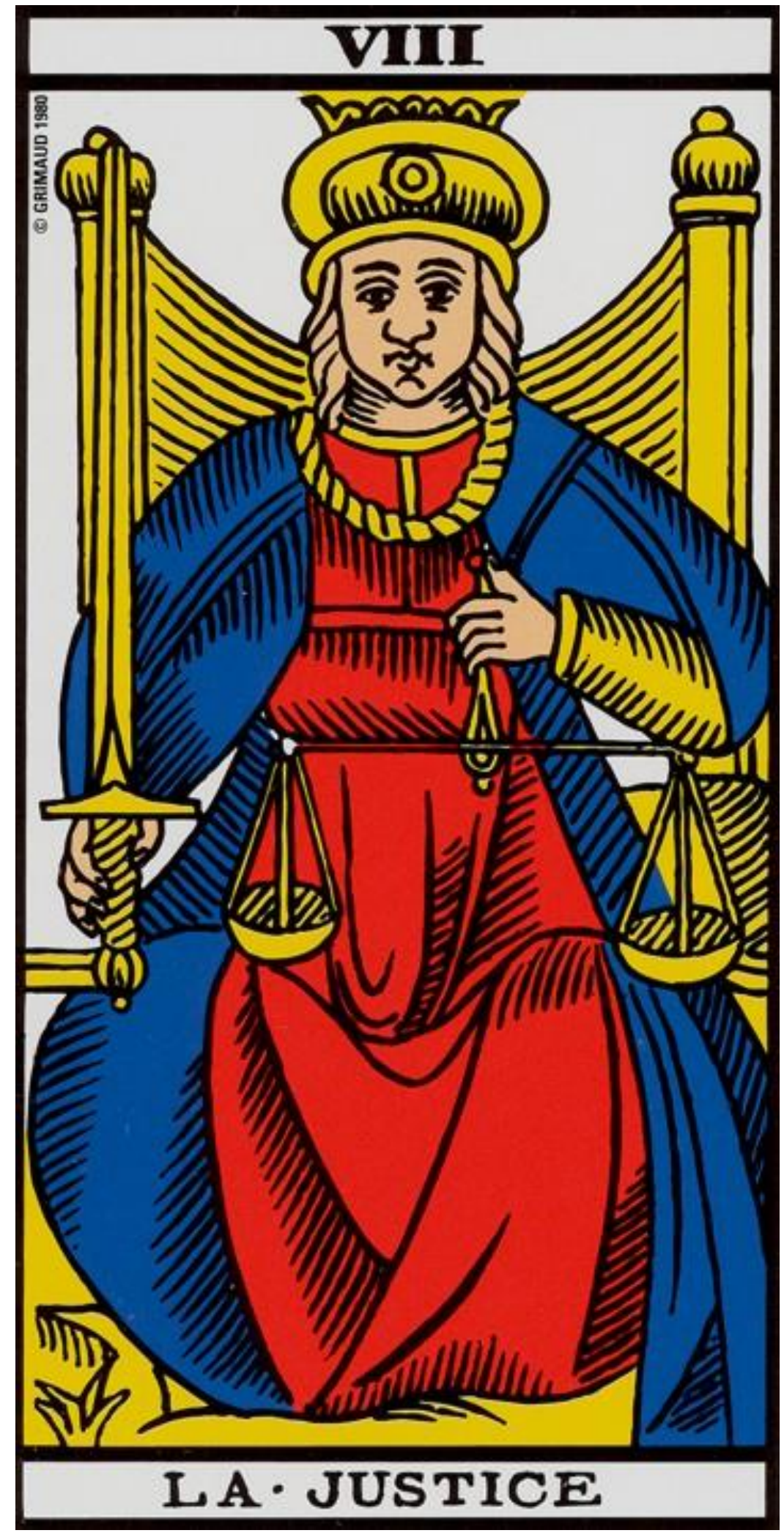




\section{8 - O Castigo de Alice}

Alice fazia de tudo para agradar o dragão. Tentava e tentava realizar os 12 trabalhos e nunca tinha sucesso. Cantava, pulava, dançava e nada dele sorrir. Alice queria que em algum momento o dragão a enxergasse. Que ele percebesse que ela era uma menina do bem, que Alice queria eram risos sem fim, música no quintal, bolo de cenoura e banhos de mar.

Por mais que Alice fizesse, tudo era pequeno para o dragão. O dragão vivia numa apatia sem fim. Sentava ao Sol e lixava as unhas, dormia, pensava na vida... O dragão nunca estava ali.

Às vezes, deitado com as mãos cruzadas sobre a barriga devaneava sorrindo, vendo as nuvens caminharem no céu. Alice ficava feliz quando o dragão estava feliz... Era como se ele pudesse vê-la, era como se ele pudesse amá-la. Mas a maior parte do tempo não era assim.

O dragão muitas vezes sorria com os olhos e gritava para que Alice se escondesse na sala sem cantos. Não havia ponto de fuga e Alice ficava correndo em círculos, procurando por uma fresta para se enfiar...

Um dia o dragão deu a ela um cachorro, um cachorro preto. Seu nome era Castigo.

Onde Alice fosse deveria levar Castigo com ela. Isso foi um grande problema para Alice que gostava de voar, dançar, correr. Como ser livre com um cachorro a tiracolo?

E o cachorro tinha sua magia; toda vez que o dragão entristecia ou se aborrecia, Castigo crescia e ficava pesado $e$ lento. 
Castigo foi sem dúvida um dos maiores desafios da vida de Alice. Não importava se Alice estava perto ou longe do dragão e não importava o que Alice sentia, Castigo sempre esteve ligado só ao dragão e foram muitas as vezes, que Castigo derrubou Alice no chão.

Muitas foram as vezes que Alice feliz, voando, viajando, sonhando ia em alta velocidade pelo céu, pronta para apanhar estrelas cadentes, ela e seu cãozinho puxado pela coleira... era até bonito de ver, a língua do cachorro que caía para o lado molhando suas orelhas. Ela e o cachorro feliz. De repente, Castigo crescia, virava um imenso estorvo, uma carga de navio, e os dois despencavam lá do céu. Até Castigo entristecia ao ver a felicidade de Alice se apagar.

Alice tentou gostar de Castigo, mas no fundo, Alice sempre desejou a sua morte. 


\section{1 - Faz de conta, faz de verdade! $O$ trabalho na infância}

No conto anterior de Alice, há referência aos doze trabalhos que lhe foram dados pelo dragão. Este ponto não foi discutido, porem ele é novamente citado e o discutiremos agora. Nos contos, esses doze trabalhos estavam relacionados a uma "prova" a que Alice foi submetida pelo dragão. Se Alice vencesse a prova, seria então aceita pelo dragão que passaria a amá-la.

Quando escrevi o conto, me referia a minha relação com o trabalho doméstico e a própria relação com o espaço escolar como um trabalho, um lugar onde se era esperado um resultado, alguma produção e aprovação.

Se minha relação com a escola era de não pertencimento, havia, porém, outro lado sobre o estar neste lugar - a possibilidade de não estar em casa. Depois que nos mudamos para a praia, minha mãe foi ficando cada vez mais infeliz. Este processo começou logo que ela engravidou, mas foi piorando, piorando e ficando cada vez mais difícil ficar com ela. Eu sempre adorei ir para a escola, porque estando na escola não estava em casa. Lembro-me de chorar cada vez que eu perdia a hora e de quando acordar de manhã se tornou uma responsabilidade só minha. Não me lembro de ter me atrasado nenhuma vez.

Mesmo quando tinha excursão que eu não ia, que o dia na escola era falido, que era sobra de feriado, eu estava lá na escola. Apesar de a escola ser esse lugar de não estar, eu adorava estar lá... Minha cabeça ia tão longe, eu falava com muitas pessoas, mudava de lugar, sentava na frente, atrás, no meio, não fazia lição de casa, nem trabalho. Era frequente levar bilhetes, 
esconder e falsificar assinatura. Como minha mãe era muito brava, eu tinha muito medo e, daí, fazia de tudo para as más notícias não chegarem a ela. Ela não era de frequentar reuniões, então a vida escolar vinha só pelo boletim, que quase nunca tinha uma nota vermelha.

Minha mãe vivia me ameaçando, dizendo que seu eu repetisse o ano voltaria a estudar na escola pública e eu não queria sair do Colégio Santa Maria. Por isso, não tirar nota vermelha era uma preocupação, apesar de nunca ter feito muito esforço para isso não acontecer. Eu conseguia tirar nota com o que eu aprendia, com o pouco que prestava atenção na aula. Não me lembro de estudar para provas até a sexta ou sétima série. Eu simplesmente tirava nota.

Em casa tudo era muito difícil. Tinha que cuidar da casa e da minha irmã. Eu tinha muitas obrigações domésticas e minha mãe era muito rígida. Nada do que eu fazia estava bom, por mais que eu me esforçasse. Sempre foi muito difícil para minha mãe me elogiar e até hoje é. Quando eu fazia algo bacana, ela achava um defeito e, se não achasse, dizia que era obrigação ter feito certo.

Lembro-me muito de tentar por diversas vezes fazer o melhor para agradá-la, mas nunca conseguia. Claro que eu também protelava. Muitas vezes ela pedia as coisas e saía, eu fazia tudo, menos o que ela havia pedido. Muitas vezes sabia o horário em que ela voltaria e até ela voltar, nada de nada... Uns minutinhos antes eu rapidamente organizava tudo e terminava. Se ela chegasse antes, vinham as consequências.

Logo que mudamos, meu padrasto começou mais um novo negócio: venda de ventilador de teto. $\mathrm{Na}$ época, era um luxo, um 
achado. Não era comum colocar ventilador de teto em casa e fomos pioneiros na baixada. Só havia um lugar em Santos que nos fazia concorrência. Assim, trabalhando com afinco, logo prosperamos. Lembro-me que tivemos um salto na qualidade de vida e os tempos de pobreza logo deram lugar aos de fartura. Porém, vivíamos sempre uma inconstância financeira, ora tínhamos muito dinheiro, ora dinheiro nenhum.

Logo, meu padrasto alugou uma edícula e abriu uma revendedora de ventiladores, pois até então tudo era feito em casa. Eu, muitas vezes, passava o dia na edícula trabalhando, atendendo o telefone, passando informações e até fechando negócio. Eu tinha entre 10 e 11 anos e trabalhei como vendedora até o segundo ano do Ensino Médio.

Por meio deste relato, percebe-se que a escola, assim como o trabalho doméstico e o comércio, eram vistos por mim como situações nas quais eu estava à prova, onde deveria fazer certo. Era para mim mais do que uma participação nas atividades familiares, era uma forma de tentar mostrar à minha mãe que eu merecia seu reconhecimento.

Sobre esta questão, há um encontro com a vida de Mestre Alcides, que muito novo saiu de casa para trabalhar. Em seu relato "Nós éramos em treze irmãos, hoje nos somos em onze, dois falecidos. Como eu saí muito cedo de casa, com onze, dez anos, porque antes de eu vir para São Paulo, com onze anos, doze anos, treze anos eu já sai de casa para trabalhar também, eu trabalhei em Goiás muitos anos. Eu e meu tio, meu tio Chico que é esse que é capitão do terno que fez noventa anos. Mas na minha época, nas cidades apareciam os caminhões tipo boiafria, ligava o microfone, chamava para trabalhar, a gente ia e 
ficava seis meses, sete, oito meses fora da cidade. Então, eu sozinho saí muito para trabalhar. Eu nunca fui de ficar naquele lugar ali, e meus irmãos...Eu tenho irmãos que eu praticamente não conheço, porque eu tenho irmão de quarenta anos de idade, eu tenho sessenta e sete, eu nunca vivi com ele porque quando ele nasceu eu não estava em casa, saía de casa, voltava um ano, dois anos depois. Em casa, eu ficava um semestre, saía, ficava mais um ano, dois anos fora...”

O trabalho veio cedo para a vida de Mestre Alcides, de forma muito mais dura do que na minha vida. Para o mestre, o trabalho era também uma forma de ganho financeiro, de subsistência.

No entanto, encontro um elo nessas passagens. Este encontro talvez se expresse na própria comparação com os "doze trabalhos de Hércules" e do simbolismo por trás deste mito. Os doze trabalhos de Hércules são comumente associados à evolução e ao desenvolvimento espiritual da jornada humana. Talvez por isso Alice nunca consiga realizar os trabalhos, por serem meras representações simbólicas da minha experiência de vida, que por inacabada, pressupõem uma jornada ainda em curso.

Essa fase da relação com o trabalho, que para mim e Mestre Alcides se deram de forma precoce, pode ser vista como um obstáculo a ser vencido no processo de nosso amadurecimento enquanto indivíduos. Se os trabalhos de Hércules eram tarefas da ordem do sobre-humano, talvez, passar por essas experiências, tenha sido para mim algo que exigiu, naquele momento, maior competência ou habilidade do que eu 
dispunha enquanto criança. Talvez, daí, o sentimento de fracasso, de incompetência ou inabilidade diante da situação.

Mestre Alcides não traz esse sentimento em seu discurso. Porém, foi esta a análise que fiz ao imaginar sua experiência com tão pouca idade.

Nesta passagem, não há encontro com Matheus. Em seu depoimento, ele cita sua primeira relação com o trabalho aos dezessete anos. Assim, sua parte será discutida em próximos contos de Alice.

\section{2 - Quem sou eu? Alice}

Este talvez seja um dos contos mais importantes de toda história de Alice. Aqui, somos apresentados a um novo personagem, que seguirá Alice quase até o fim. Seu nome é Castigo, um cachorro com uma característica mágica "toda vez que o dragão entristecia ou se aborrecia, Castigo crescia e ficava pesado e lento".

Castigo foi um presente do dragão e foi dado a Alice para segui-la em todos os seus passos para o resto de sua vida. Começaremos a análise, com o resgate do trecho autobiográfico em que Castigo foi criado.

Eu tinha entre nove e doze anos nessa passagem de Alice, morava na Vila Caiçara, na Praia Grande, lembro-me de cenas, situações, flashes... Lembro-me que eu ganhei a rua, brincava muito. Lembro-me da minha mãe sendo cada vez mais infeliz.

Lembro-me da minha irmã e de mim crescendo. Eu era quem mais cuidava dela. 
Uma vez, fui buscá-la na escola e, na volta, ela caiu. Ela tinha por volta de três anos. Peguei-a no colo, brinquei, tentei fazê-la parar de chorar. Cheguei em casa, ela estava meio mole, parecia que ia dormir. Minha mãe levantou seu cabelo que caia sobre a testa e havia um hematoma enorme. Eu devia ter uns doze anos. Levaram-na para o hospital. Eu chorava muito, me sentia culpada pelo ocorrido.

Minha mãe dizia que se ela morresse ou ficasse "retardada" - era o termo que minha mãe usava - a culpa seria minha... Ela foi para a UTI com traumatismo craniano.

Eu sofri muito com a culpa.

Em três dias ela voltou para casa e, depois desse fato, caiu mais umas três vezes de cabeça no chão. Está aí uma coisa que minha irmã fez muito: "galo" na cabeça.

Não! A culpa não foi minha, foi um acidente.

Também teve o caso do cachorro. Nós tínhamos um pastor alemão e minha mãe tinha uma relação de muito carinho com ele. Um dia, saímos para passear com ele... Andamos, andamos... Sugeri que fôssemos visitar uma amiga da minha mãe. Na volta, o cachorro deitou no chão e não levantou. Fizemos de tudo e ele não saía do lugar. Minha mãe conseguiu um carrinho de construção, colocou o cachorro dentro e foi carregando até em casa.

Minha mãe dizia: "Se o cachorro morrer, a culpa é sua que quis fazer este passeio!"

Meu padrasto chegou de carro, botaram o cachorro dentro e foram embora. Eu chorava muito. Não queria ter causado tamanho infortúnio. 
A vizinhança inteira me via caída no chão aos prantos pelo cachorro e por minha culpa. Eu mesma tinha dó de mim. O cachorro não voltou. Teve um ataque cardíaco e a culpa ficou sendo minha.

Não a culpa não foi minha.

No jogo de culpas que minha mãe articulava, eu me enredava como qualquer criança e passava a acreditar que era culpada.

\section{3 - O dragão, a sombra do dragão, o cachorro Castigo}

Durante a análise desse conto, a primeira coisa que me chamou atenção foi o personagem Castigo. Ao ler a autobiografia, fica clara a representação simbólica de um castigo dado a uma pessoa culpada. Porém, como Alice é escrita de forma espontânea e sem intenções diretas de escolhas de símbolos, eu mesma não sabia o que havia por trás de Castigo.

Ao ler "O homem e seus símbolos", encontrei um primeiro fio que poderia servir como um início do tecido desta análise.

“O self é, muitas vezes, simbolizado por um animal que representa a nossa natureza instintiva e a sua relação com o nosso ambiente. (É por isto que existem tantos animais bondosos e prestimosos nos mitos e contos de fadas.) Esta relação do self com a natureza à sua volta e mesmo com o cosmos vem, provavelmente, do fato de o "átomo nuclear" da nossa psique estar, de certo modo, interligado ao mundo inteiro, como interior como exteriormente. Todas as manifestações superiores da vida estão, de uma certa maneira, sintonizadas com o contínuo espaço-tempo. Os animais, por exemplo, tem sua alimentação especial, seu material particular para construir sua habitação, e seus territórios bem definidos, com os quais os seus esquemas instintivos encontram-se perfeitamente ajustados e adaptados. (...) Foi com estas considerações em mente que um zoólogo famoso logo declarou que o 'interior' de cada animal se estende 
amplamente sobre o mundo à sua volta, 'psiquificando' tempo e espaço" (Jung, 2002b, p. 207)

Para dar continuidade a esta análise, é preciso alguma definição sobre self. Recorro a Jung, que tem sido minha principal referência sobre a construção simbólica humana. Jung define self como "o núcleo mais profundo da psique" - o símbolo da totalidade. Sobre a construção do self, Jung explica;

\footnotetext{
"Nos sonhos da mulher este núcleo em geral é personificado por uma figura feminina superior - uma sacerdotisa, uma feiticeira, uma mãe-terra, ou uma deusa da natureza ou do amor. No caso do homem, manifesta-se como um iniciador masculino ou um guardião (...)" (Jung, 2002b, p. 196)
}

Ora, se o self feminino representa a totalidade, a comunhão entre anima e animus, o mais profundo da psique, Castigo não poderia representar o self; ele compõe "parceria" com Alice. Poderia Castigo, aparecer como personificação do animus - a personificação masculina do meu inconsciente. No conto anterior de Alice, já seria possível encontrar traços do animus que se forma no encontro com o personagem "homem sem face". Este personagem, que diretamente dialoga com uma pessoa real da autobiografia, mas que também simboliza o paterno ausente e sem face, sempre só como uma sombra, um vulto; mas que ainda assim, orienta e guia por um caminho.

Nas experiências que vivi e que foram relacionadas diretamente a um julgamento de culpa sobre ação ou castigo sobre culpa, mais o conjunto de elementos constituintes do espaço-tempo vivido devem ter sido a base para a então construção do animus, que poderia ser representado simbolicamente por um cachorro. 
A imagem do cachorro é frequente em mitos e lendas de diversas civilizações, Chevalier faz a seguinte menção à presença desta figura na mitologia:

"Sem dúvida não existe nenhuma mitologia que não tenha associação ao cachorro, Anubis, rien-K'uan, Cerbero, Xolotl, Garm, etc., a morte, aos ... infernos, ao mundo inferior, aos imperior invisieis que regem as divindades ctônicas e seléricas. A complexidade do símbolo do cachorro esta ligado a primeira vista com a trilogia dos elementos terra, água, lua, do que se conhece do significado oculto, sombra, as vezes vegetativa, sexual, divinatória, fundamental tanto para o conceito de inconsciente como para subconsciente (Chevalier e Gheerbrant, 2005, p. 816)

E destaca duas principais funções simbólicas: 1. "a função de condutor de almas, guia do homem na noite da morte, depois de ter sido seu companheiro no dia da vida"; 2. "a função de intercessor entre este mundo e o outro, de intérprete para os vivos, para interrogar os mortos e as divindades soberanas de seus pais" (idem). O cachorro é ainda símbolo de lealdade, guardião. A dualidade entre o que guarda a vida e vela a morte. Na definição de Chevalier e Gheerbrant, há ainda uma menção que pareceu próxima à ideia de Castigo.

" (...) o simbolismo do cachorro no Extremo Oriente é essencialmente ambivalente: benéfico, pois o cachorro é o companheiro próximo do homem e o guardião que vigia sua morada; maléfico, pois parente do lobo e do chacal, parece um animal impuro e depreciável” (p. 820)

Pareceu-me, num primeiro instante, que Castigo assumisse esse papel ao representar o animus que compõe par com o dragão. Apesar de aparecer na imagem de um cachorro companheiro, que estaria com Alice durante toda sua jornada, Castigo é também aquele que a pune em função dos afetos do dragão - há uma composição explícita de ação e reação na 
ligação entre o dragão e Castigo, que se revelaria no ser Alice - a então representação do self.

Assim, seria possível compor a tríade que certamente ditaria a forma como Alice atua em sua jornada. A partir deste ponto, sua condição de existência estaria sempre ligada à maneira como seu feminino e seu masculino interagem com o tempo-espaço vivido.

No entanto, algo me chamou atenção. Primeiro, o fato de o personagem dragão ir se distanciando de Alice. Ora estava presente, ora era apenas uma sombra e será assim que seguirá até desaparecer na trama. Segundo, apesar de não poder adiantar o destino dos personagens em Alice, é preciso dizer que Castigo não segue Alice até o fim de sua jornada. Se o dragão vai assumindo um distanciamento de Alice e Castigo tem seu fim antes de Alice, juntos - ou de forma independente - não poderiam representar anima e animus.

Foi no mito de "A Bela e a Fera" que encontrei uma resposta mais coerente para a representação simbólica desses personagens. A escolha do cachorro como representação do Castigo, pareceu-me ter ligação direta com o cachorro morto na autobiografia, assim como a escolha do dragão com minha mãe.

Nas análises anteriores, vou relacionando a figura do dragão à constituição do feminino, da fertilidade, da própria anima. Essa leitura, de alguma forma parecia fugir do que de fato eu gostaria de trazer para o texto e, apesar de concordar que o dragão possa compor a anima, ele em si não é a sua pura representação.

Henderson (2002) nos conta sobre o simbólico por trás da luta herói-dragão, na qual o dragão pode representar "a imagem 
simbólica do aspecto 'devorador' do apego à mãe”, enquanto que a batalha em si, expressa o processo de crescimento e rompimento desta ligação "devoradora", para a então descoberta da autêntica função da anima no sujeito.

No mito "A Bela e a Fera", a "Bela desperta para o poder do amor humano disfarçado na sua força animal (e, portanto, imperfeita), mas também genuinamente erótica". Alice ainda não é capaz de libertar-se desta força animal que toma forma no cachorro Castigo; uma força repressiva sobre a imagem de si e à imagem que faz do masculino. Por isso, Castigo não representa o animus, e sim, o compõe - sendo expressado como a forma com que Alice passa a construir suas relações no mundo.

É dito que "Alice não confia em mais ninguém" e enquanto se mantém ligada a Castigo, não poderá "tomar consciência de sua capacidade de confiar no amor como um sentimento onde natureza e espírito estão unidos, no mais elevado sentido destas palavras", como complementa Henderson na análise do mito "A Bela e a Fera" (Henderson, 2002, p.137).

Numa leitura mais singela, a relação com o dragão representa meu crescimento, enquanto Castigo representa Alice (ou eu) em sua forma anímica, que precisa ser trabalhada, vivida, sentida e possa reaparecer como o eu-persona amadurecido e humanizado - um renascimento em mim. 


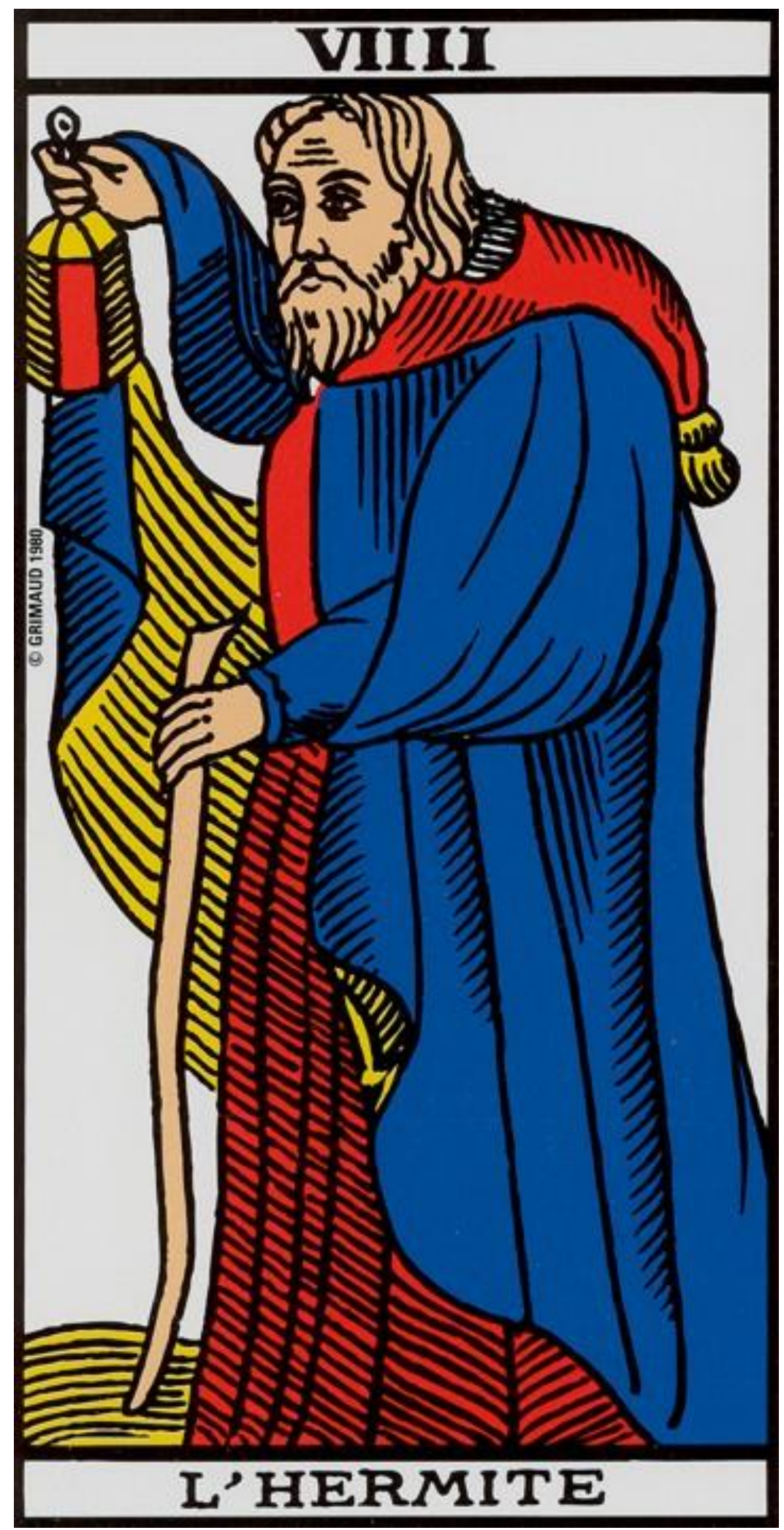




\section{9 - Alice e as princesas}

Alice sempre foi muito sozinha. Apesar de ser só uma criança, Alice carregava muito peso com ela. Levava o cachorro preto a tiracolo, a sombra do dragão sobre sua cabeça e as lembranças dos meninos de luz. Muita bagagem, muita memória e muita dor a acompanhavam.

Era dificil fazer amigos assim. Muitas vezes, a sombra do dragão chegava antes dela e assustava as pessoas às quais ela pensava em se aproximar. Outras vezes, era o cachorro que, de tão grande, ocupava todo o espaço e impedia Alice de enxergar possibilidades.

Em suas andanças pelos parques, brejos e castelos, Alice avistou um lago e, à sua margem, um gramado. Um lugar lindo de grama aparada, flores do campo, cheiro de jasmim.

Alice viu muitas meninas brincando, elas usavam vestidos, sapatos, coroas. Algumas gostavam de usar bermudas, tênis e camisas de botão, mas todas usavam pequenas coroas. Eram cheirosas, tinham os cabelos brilhantes e a pele de carinhos de algodão.

Elas sorriam muito, brincavam juntas de rodar, de cair no chão, de correr e de fazer bolhas de sabão. Tinha menina de todas as cores. Eram princesas amadas.

Alice ficou encantada, foi se aproximando com cuidado para não ser vista... Alice tinha medo de chamar atenção! Ficou ali observando por horas aquela festa de princesas. Alice gostou tanto, que traçou um caminho para voltar todos os dias e ver as meninas travessas. Um dia, sem querer, Alice espirrou, mas 
espirrou tão alto que mexeu a folhagem do arbusto onde se escondia.

As meninas pararam tudo o que faziam, houve um minuto de silêncio e depois, uma gritaria de ensurdecer. Saíram correndo para descobrir o espirro e deram de cara com Alice.

Alice e as meninas... As meninas e Alice.

Nem foi preciso dizer nada, pegaram na mão de Alice e a puxaram para brincar de princesa. Nem se deram conta de que Alice não tinha coroa e ainda pensaram que o cachorro de Alice era um brinquedo engraçado, que deixava Alice ainda mais interessante.

Alice se fez princesa. Sozinha em casa, pegou uma lata de leite condensado, tirou todo o leite e só deixou o doce grudado no flandres. Com uma tesoura bem forte, recortou sua coroa. As meninas nunca saberiam que Alice era princesa de si mesmo... Não tinha Reino, não tinha Castelo, não tinha Rei, nem Rainha... Alice só tinha Castigo e um dragão. Ao dragão ela deu nome de Rainha e ao Castigo ela deu o nome de Cachorro. 


\section{1 - O espelho - sinais dos primeiros reconhecimentos do eu como persona}

Este conto de Alice fecha o ciclo da infância. Aqui, Alice se encontra com um grupo, no qual pela primeira vez Alice se empodera de um papel que pretende assumir e se reconhece com iguais. Alice, não é mais aquela que observa, agora Alice age.

O conto se relaciona ao final da fase em que morei na Vila Caiçara, onde me lembro da segunda infância. Foi lá que comecei a crescer e me descobrir não só como menina, mas como mulher.

Quando estava na oitava série, nos mudamos para uma casinha no Jardim Imperador, bairro mais afastado da Vila Caiçara e do centro da Praia Grande. Era um bairro bem pobre, e a casa, recém-construída, novinha. Tinha um quarto, sala, cozinha, banheiro e quintal. Mudamos para essa casa porque meu padrasto estava comprando um apartamento e realizando, enfim, o sonho da casa própria. Como morávamos de aluguel, foi preciso economizar. Nós não tínhamos móveis porque a casa anterior era mobiliada, assim, além de pouco espaço, tudo era improvisado.

Eu dormia na sala, e minha irmã, com os pais no quarto. Todos os cômodos eram bem pequenos. Eu não era mais criança. Lembro-me de mim já adolescente. Não tinha vergonha nenhuma de morar ali, mas minha mãe tinha. Na frente da casa tinha um terreno com uma casa-barraco onde morava uma família de negros pobres.

Eu fiz amizade com o pessoal. O lugar era muito pobre, mas eu gostava. Lembro-me de cuidar de uma família de patos... Era quase um sítio. Tinha muitos bichos por perto. 
Agora eu não era mais uma autista na escola. Comecei a descobrir meu potencial como aluna, eu passei a dar conta sozinha das minhas coisas e agora conseguia me organizar com lições, trabalho e estudo. Passei a ser boa aluna na escola, tirar notas boas e ser reconhecida. Fiz amizades novas e consegui entrar para a turminha de meninas "legais e inteligentes" da sala.

Cursava o último ano no Colégio Santa Maria e éramos a turma dos mais velhos da escola. Um terror, mas uma delícia! Eu fiz grandes amigas e foi ótimo ter me encontrado antes de sair do Santa, porque pude entrar no Ensino Médio com mais segurança dos meus potenciais. Poder ser vista e aceita por aquele grupo de meninas foi das coisas mais importantes da minha vida. Creio que só passei a acreditar em mim depois que elas o fizeram e acho que estar aqui hoje é resultado desse encontro.

Encontro também com o percurso de Matheus, que em seu relato de vida traz as memórias ligadas aos meninos da rua, às travessuras, aos seus heróis, que nesse passo para a adolescência vão se construindo como referências. Matheus em seu relato: "Teve um tempo que eu vivi em São Paulo, mas eu ficava entre São Paulo e São Carlos... ficava lá em Pinheiros. Fiquei um tempo lá, com uma tia, mas eu ficava um pouco lá, um pouco cá (...) televisão, eu só fui conhecer quando tinha doze anos na casa da minha tia, em São Paulo (...) tinha uns primos em São Paulo, sempre mantinha contato e lá eu conheci televisão, então toda vez que ia para são Paulo eu via televisão, tinha um programa na televisão chamado Vigilante Rodoviário, que eu era fã, Lessie (risos), tinha Turma do Sete, na Record, tudo assim, uns programinhas meio infantis, mas eram interessantes, eu gostava. E em São Carlos, mesmo, eu 
tinha uns quatorze anos quando chegou a televisão em São Carlos. Meu vizinho tinha uma televisão. Ele era inspetor de ensino. Tinha um cargo mais elevado, sabe? Naquela época professor tinha um certo status, sabe? ... E ele era um acima de diretor. Ele já foi professor, depois subiu, então ele era uma pessoa que tinha mais recurso... Ele tinha um carro, naquela época só tinha carro importado, não tinha nacional, tinha casa na praia, no Guarujá... Ia todo ano para o Guarujá, sabe? Era assim! Era sócio do São Carlos Clube... Tinha piscina no São Carlos Clube. Uma vez por semana (a gente) ia assistir televisão na casa dele para assistir o Vigilante Rodoviário.

A gente ia toda quarta-feira, eu não esqueço, assistir o Vigilante Rodoviário... E aí, a mulher lá, a mãe do Paulinho, acabava o filme, ela já ia e apagava a televisão: 'Bora, todo mundo, bora (ao som de palmas)'. A minha mãe, coitada, se esforçou e comprou uma televisão depois. Isso eu tinha quatorze anos, mas mesmo assim a gente assistia aqueles filminhos lá... desenho animado. Mas no dia a dia era rua, brincava de bola, futebol.

O bairro, era molecada que vivia ali, que muito bem, em harmonia, brincava de Tarzan. A nossa referência era Tarzan, os filmes de faroeste. Nosso referencial era esse. Tinha as matinês no cinema de São Carlos, então a gente tentava imitar nas nossas brincadeiras (...) brincava de espora, de Tarzan, de... (risos) índio...”

O que chama atenção nesses encontros de vida que não se encontraram, são as similaridades das buscas, das construções de modelos, das experiências do crescimento. 
Apesar de estarmos tão distantes em tempo, idade e geografia, nessa fase entre os doze e quatorze anos, foi o momento de viver em grupo e, de alguma forma, já ir buscando caminhos que conduzissem à vida adulta, ir buscando construir no imaginário "o que seria quando crescesse".

O que salta de Alice, minha autobiografia, e a de Matheus são os modelos, os heróis, os arquétipos que vão servindo como base para construção do eu-adulto. Em Alice surgem as princesas; na vida de Matheus, os cowboys e o Tarzan.

Sobre as escolhas dos arquétipos em Alice, a primeira pergunta que me fiz foi: "Por que antes foram fadas e agora foram princesas?". A escolha dos personagens em Alice não foi estudada, como já dito. Os contos foram escritos intuitivamente e só nas análises é que perguntas como estas foram sendo respondidas.

A princípio, a escolha parece não importar. Ao buscar suas referências simbólicas nós vamos nos encontrando nos escritos sobre arquétipos, e nos vendo cada vez mais ligados ao coletivo, ao social, ao ancestral. Vamos nos dando conta de que nossa memória, nosso imaginário, não são apenas construções individuais ou coletivas ligadas a um determinado tempo e espaço. Somos seres cujo imaginário transcende, seres que apesar de etéreos trazemos conosco certa eternidade, deixamos no mundo alguma cicatriz. Passamos pela vida carregando um monte de outras vidas desconhecidas, guardadas em nosso inconsciente. O ser humano é rede, nunca é um.

As princesas aparecem no momento de transição entre a infância e a adolescência. Por que princesas? 
"Na linha de Jung, a princesa representa o arquétipo da donzela, preparando-se para iniciar a vida amorosa, sexual e constituir família, encontrando o príncipe encantado" (Correia, 2010, p. 09).

A escolha pelas fadas, anteriormente, deu-se pela infância inocente que aquele momento representava: a magia, o encantamento, a imanência do imaginário infantil. Agora passamos por um processo de amadurecimento, um marco. A princesa é um símbolo de iniciação. Momento que "marca o aparecimento do ego individual na transição da infância para meninice" (Henderson, 2002, p. 128).

O mito do herói, segundo Henderson, parece ser a primeira etapa na diferenciação da psique. No caso de Matheus, os heróis aparecem personificados nas figuras dos personagens da TV, dos filmes, dos desenhos. Os heróis representam os ritos de iniciação: separação, iniciação e retorno (trata-se do monomito, segundo Campbell):

Um herói vindo do mundo cotidiano se aventura numa região de prodigios sobrenaturais; ali encontra fabulosas forças e obtem uma vitoria decisiva; o herói retorna de sua misteriosa aventura com o poder de trazer beneficios aos semelhantes. Prometeu foi aos céus, roubou o fogo dos deuses e voltou à terra. Jasão navegou por entre as rochas em colisão para chegar a um mar de prodigios, evitou o dargão que guardava o Velocino de ouro e retornou com o Velocino e com o poder de recuperar o trono, que lhe pertencia por direito, de um usurpador. Enéias desceu ao mundo inferior, cruzou o horrendo rio dos mortos, atirou um bocado de comida embebida em uma substancia calmante ao cão de guarda de três cabeças, Cérbero, e finalmente conversou com a sombra do seu falecido pai. Tudo lhe foi revelado: o destino dos espíritos e o de Roma, que ele estaba por descubrir: "e, com essa sabedoria, ele poderia evitar ou enfrentar todas as provações". Retornou, pasando pelo portão de marfim, ao seu trabalho no mundo”. (Campbell, 1997, p. 36)

A ressonância dos arquétipos é também produto das imagens que consumimos, fato muito bem observado no relato 
de Matheus. Se vivemos num mundo cultural rodeado de imagens, estas de certa forma moldam também nosso imaginário.

"O exterior impõe-se ao indivíduo, sendo o corpo alvo reiterado do poder da imagem. Diariamente, somos confrontados/as com certos modos de pensar, agir e sentir, que nos colocam em determinados lugares, contribuindo para a nossa constituição como sujeitos portadores de uma identidade, em que a representação e a imagem do ser humano têm um papel fundamental, colocando os sujeitos frente a um permanente espelho" (Correia, 2010, p. 03)

Há uma relação direta entre as imagens produzidas pelo indivíduo e as assimiladas pelo meio em que vive. Culturalmente, ainda estamos cerceados pelo conhecimento como produto da construção ocidental branca e patriarcal. Uma cultura que se valoriza sobre outras e impõem modelos para homens e mulheres.

Se meninos escolhem heróis, meninas escolhem princesas... Ao menos, em um determinado tempo histórico.

Apesar das princesas representarem arquétipos do momento de transição da vida de menina para a de mulher, nossas releituras em contos de fadas, desenhos animados, brinquedos... trazem como representação:

“(...) um modelo hegemônico de feminilidade: etnia branca, jovem, heterossexual, magra, bonita e dócil, indo ao encontro das características que a sociedade ainda privilegia em relação à feminilidade. Além da insistência, por parte do mercado de consumo, dos signos de eterna juventude e de beleza nas representações femininas, determinando quais as mulheres passíveis de serem amadas ou desejadas, o amor romântico apresenta-se como o ideal de felicidade" (Correia, 2010, p.13)

O encontro de Alice com as princesas traz também algum sentimento de "inadequação" ao grupo, o que na verdade deve relacionar-se a um sentimento de não pertencimento a este 
arquétipo imposto pelo social. Os atributos misturados ao arquétipo original da princesa transformam o arquétipo em modelo, destituindo-o da sua função simbólica e transformandoo em um ideal utópico ou mero estereótipo.

Alice não se identifica, mas busca em sua subjetividade elementos que possam interessar às princesas e conquistar então o seu espaço. Alice quer o "idem", quer o igual, mas não se vê igual pela sua história, pela sua experiência, pela forma como se põe no mundo na representação simbólica de Castigo.

Os processos vividos por mim e Matheus podem se referir ao fim do movimento de afastamento descrito no monomito ou a fase em que começamos a nos distanciar do núcleo familiar e da vida infantil, nos preparando para o processo de iniciação. Um arremedo, um fazer-se pronto para o ritual iniciático, que nesse momento é dado apenas por reconhecimento em modelos e representações midiáticas. Numa perspectiva da antropologia simbólica de caráter hermenêutico do estudo das estórias de vida e o material autobiográfico, vemos que:

"E o universo da iniciação imanta os mitos literários. E na construção do(s) personagem(ns) estamos também em pleno universo da narrativa autobiográfica, biográfica, romanesca, como gênero literário mas todas como estórias de vida (...) ler o romance como autobiográfico e, já cruzando com os resultados da psicocrítica, vê-los como seres de linguagem de um 'moi orphique' que agencia como personagens os fantasmas, de modo que os personagens são objetos interiores postos na narratividade do texto. Permite-nos ainda ver o convite ao pacto fantasmático como uma ressonância fantasmática e um círculo hermenêutico garantidos por um 'contrato de leitura' que torna a obra aberta numa circulação fantasmático-poética (fantástica) com o receptor (...)” (Paula Carvalho, 1998, p.229 e 239) 


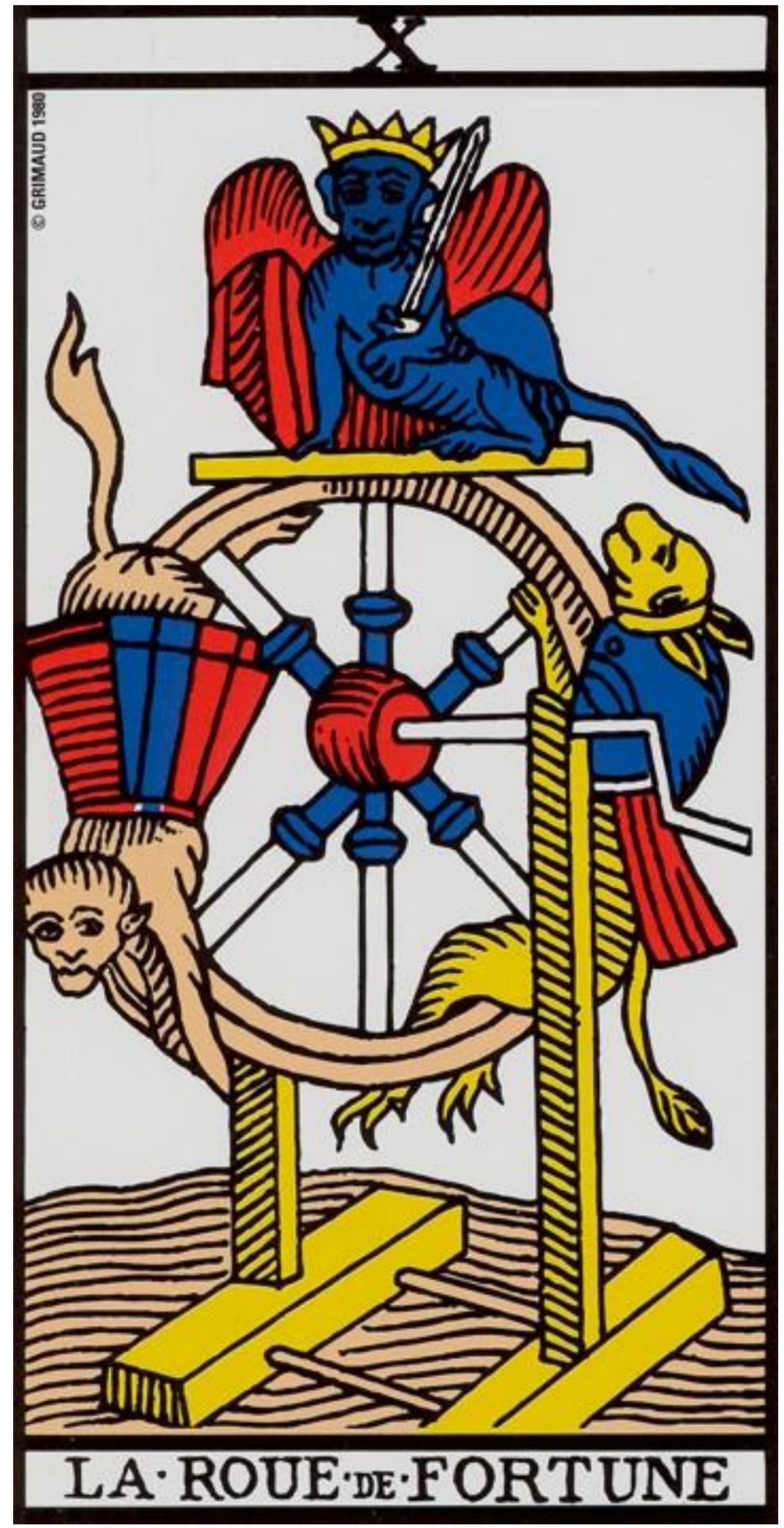




\section{Viramundo}

Gilberto Gil

Sou viramundo virado

Nas rondas da maravilha

Cortando a faca e facão

Os desatinos da vida

Gritando para assustar

A coragem da inimiga

Pulando para não ser preso

Pelas cadeias da intriga

Prefiro ter toda a vida

A vida como inimiga

A ter na morte da vida

Minha sorte decidida

Sou viramundo virado

Pelo mundo do sertão

Mas inda viro este mundo

Em festa, trabalho e pão

Virado será o mundo

E viramundo verão

$O$ virador deste mundo

Astuto, mau e ladrão

Ser virado pelo mundo

Que virou com certidão

Ainda viro este mundo

Em festa, trabalho e pão 


\section{0 - Alice e o Sátiro}

Alice, que não era mais criança, desenvolvera um corpo esguio e leve. Era magra por natureza, uma pele alva $e$ acetinada. Cabelos compridos, lisos e castanhos que combinavam com seus olhos amendoados. Alice estava sempre com um vestido branco, de tecido transparente que cobria seu corpo como quem esconde um segredo.

Alice no seu jeito de menina chamava atenção pela voz doce, pelo perfume de pitanga, pelo riso de criança. Era quase uma fada... Mas, era também um pouco bruxa.

Aquele jeito livre e brincalhão, escondia ventos devastadores... Escondia raios e trovões e foi assim, enganado pela beleza suave de Alice, que o Sátiro se aproximou.

Um dia, chamou-a para brincar. Brincar de pegar como fazia com suas outras meninas...

Alice achou aquela figura muito interessante. Tinha um corpo pequeno e desengonçado. Era feio, mas escondia dentro de si uma sabedoria que despertou a curiosidade de Alice. Brincar de pegar era novidade para Alice que aceitou no primeiro convite. Ao correrem pelos campos, o Sátiro contava para Alice muitas histórias que Alice não conhecia. Ele sabia de músicas, de contos, de encantos... No seu jeito estrambelhado era bom falador e Alice viu neste ser uma possibilidade de aprender, de conhecer mundos novos... O Sátiro era como uma ponte que Alice desejava transpor.

Alice só não sabia que o Sátiro era um caminho sem volta... Ultrapassar aquela ponte faria Alice para sempre bruxa, para sempre vento, para sempre trovão. E assim se fez! 
Alice virou bruxa para toda a eternidade.

Na sua pouca idade, Alice enganava a quem quer que fosse. Parecia mesmo uma fada... parecia que ainda era um mistério, mas não era mais. Foi o Sátiro que fez Alice descobrirse bruxa cedo demais.

Algumas poucas vezes brincando de pegar, fizeram Alice enjoar do Sátiro e logo ela se afastou. Arrependida, Alice passou a se preocupar com o dragão... O seu medo fez Castigo ganhar dentes afiados, que agora a machucariam cada vez que ele crescesse ao seu lado. 


\section{1 - Acendam as luzes! - eu, na coxia da vida.}

Este conto de Alice representa um período cronologicamente mais longo da minha vida, se comparado aos contos anteriores. Ele se refere ao tempo entre o último ano do Ensino Fundamental II e o segundo ano do Ensino Médio. Fase de transição entre a vida infantil e a adolescência.

Em 1992, entrei no Ensino Médio numa nova escola. Tudo mudou. Eu estava mais confiante e mais segura. Mudei de escola com as minhas melhores amigas. A escola parecia pública. As paredes eram brancas e sujas, tudo tinha um ar meio desorganizado, meio abandonado. Os alunos também eram diferentes. Foi lá que conheci meu melhor amigo: Miguel. Eu amava o Miguel, mas amava como amigo. Ficávamos juntos o tempo todo; na hora do intervalo, da aula vaga, da aula morta, do ponto de ônibus... Ficávamos de mãos dadas e falava sobre tudo. Ele fumava Marlboro, eu detestava cheiro de cigarro. A gente dividia a Coca-Cola.

Talvez seja das lembranças mais doces que trago da adolescência... o Miguel.

Foi no primeiro ano do ensino médio que tive um namorado negro. Éramos uma turma com todo tipo de gente. Gente de classe média e gente pobre. Não tinha muita distinção. Era uma turma acolhedora. Tinha o filho do prefeito, tinha eu, tinha filho de gari... Era a turma que se conheceu na praia, no bairro e gostava de estar junto... Pegar onda, jogar bola, tomar Sol e até tomar cerveja escondido. Nessa turma tinha um garoto muito querido, um menino negro e pobre. Eu o adorava e um dia nos beijamos. As meninas fizeram críticas porque ele era feio. 
Não porque era negro, mas porque era meio banguela, tinha pele mal tratada, o cabelo pixaim. Eu gostava dele e teria ficado com ele muito mais do que fiquei não fosse a pressão do lado de fora.

Certo dia, estava todo mundo na minha casa, minha mãe chegou, me chamou na cozinha e me obrigou a mandar todo mundo embora, inclusive o menino negro que eu estava namorando. Disse que não tinha pagado escola para mim para eu namorar preto. Foi bem ruim, me senti muito mal e logo terminei meu namoro com ele.

No segundo ano do Ensino Médio resolvemos todos mudar para uma escola pública em São Vicente. Nunca tínhamos aula, os professores faltavam muito. As salas de aula eram precárias assim como o resto do prédio. Por vezes, éramos dispensados logo depois que entrávamos, saíamos da escola e ficávamos perambulando pela cidade. Íamos para a praia, para o shopping, para o mercado...

Eu continuei sendo uma das melhores alunas da classe sem muito esforço porque a escola era muito fraca. Continuei cada vez mais para o lado de dentro da rua. Cada vez mais longe da minha família.

Meu padrasto não falava comigo e eu achava a vida doméstica muito ruim. Odiava aquela casa onde eu não me sentia bem-vinda. Eu era literalmente "uma estranha no ninho". Sempre inventava motivos para ficar fora: cursos, oficinas, palestras, passeios... Um dia, entrou um homem durante a aula na escola e fez um convite para um curso de teatro gratuito na própria escola.

Fui à primeira aula e adorei. Meu primeiro grupo de teatro. O professor era uma pessoa interessante. Tinha um cabelo 
moicano, usava calça jeans rasgada, uns alfinetes presos na calça, camiseta regata branca e uma corrente com um cadeado na cintura. Ele era muito inteligente. Falava de coisas que eu nunca tinha ouvido... Poesias, livros, músicas... Falava de política e era anarquista. Ele era anarco-punk.

Logo estávamos namorando. Ele tinha 24 e eu tinha 15 anos. Eu só tinha 15 anos. Eu era muito jovem e achava que já era grande, muito grande.

Ele forçava para que tivéssemos relações sexuais. Eu negava até onde conseguia, mas pensava que se eu não cedesse a um homem de 24 anos, ele terminaria o namoro comigo. Um dia, eu cedi. Não foi porque eu quis, nem porque eu estava apaixonada. Um dia, eu cedi. Só depois descobri que para essa primeira vez, podia ter dado o nome de estupro de encontro.

Fiquei nesse relacionamento por três meses. Ele gostava muito de mim, me ensinou muito. Devo a ele meus primeiros discos do Caetano Veloso, do Vinícius de Moraes, do Tom Jobim. Li muito sobre anarquismo, fui a encontros punks, shows e bares de gente diferente. Dormíamos na casa dele. Ele tinha um pai debilitado que vivia de cama e uma mãe que trabalhava muito para manter a casa. Ele nadava, lia, ouvia música, fumava maconha, lia mais, dava aulas de teatro, fumava maconha, lia... Sua vida era mais adolescente que a minha.

Sinto um profundo arrependimento por ter cedido. Descortinei a parte que faltava para o palco da vida. Agora eu sabia o que os adultos faziam. Eu efetivamente havia me feito mulher.

Sobre Alice, podemos inferir sobre os aspectos simbólicos que representam toda esta transição e a iniciação dada pela 
mudança de escola e pela minha primeira experiência sexual. Alice é descrita como uma menina quase mulher, com uma sensualidade implícita, escondida em seu vestido branco e transparente. Alice é sedução ainda em fase de brincadeira. Alice sabe que seduz, mas ainda não sabe o significado desta habilidade. Ela brinca com essa nova característica, da qual vai se apropriando em seu caminhar pela vida. No texto, me refiro a Alice como uma quase fada, que, no entanto, em sua apropriação com o feminino sensual, se aproxima de uma ninfa.

"Divindades secundárias femininas representantes da força que preside a reprodução e a fecundidade da natureza vegetal e animal. (...) Jovens, belas e delicadas, as ninfas eram objeto de paixão não só dos mortais, como dos próprios deuses. (...) São descritas como jovens com tecidos leves, quase transparentes, tendo os cabelos prateados, compridos e soltos ou penteados em tranças. (...) Algumas portam arco e flecha" (Abril Cultural, 1973, p. 132)

No conto de Alice não há referências diretas às passagens anteriores ao encontro com o Sátiro dessa forma subjetiva na descrição dessa liberdade e curiosidade sobre o mundo, dessa leveza na imagem construída de uma menina que busca descortinar mundos. As ninfas, assim como eu nesse início de adolescência, não andam sós. São criaturas que vivem em bandos, representação de um feminino jovem, ligado ao ambiente natural dos mais variados. Elas vagam, descobrem, brincam com seus corpos agregando-se à natureza, como parte de um cenário quase romântico, mas de uma inocência ainda infantil. "A ninfa é uma menina na cabeça e uma mulher corpo abaixo, a natureza, a montanha e as grutas, sendo ninfa, ela não deve jamais ser violada, somente profanada”. (Barbosa, 2008, p. 85) 
No entanto, as ninfas são símbolos de jovialidade e "nunca envelhecem”, apesar de serem mortais. No conto, Alice é fada e as fadas são imortais. Segundo Trindade (2008), as fadas tinham o conhecimento das metamorfoses e das ervas e podiam se transformar em mulheres belas ou feias, ligando-se, assim, à imagem das bruxas, como se dá em Alice.

O encontro com o Sátiro é marcado por uma ludicidade, um despertar de um imaginário proibido. Alice sabe que pode seduzir o Sátiro e ele já a seduz em sua estranheza, representada em sua monstruosidade de ser. Neste corpo dual, nesta mentesexo, neste homem-bicho.

Episódio que na autobiografia fica bem marcado pelo contato com o masculino, que vai se dando aos poucos neste início de adolescência. Uma sedução que gera culpa, uma sedução que não pode ser experimentada em toda a sua amplitude. Há um ir e não ir, um entregar-se sem entrega, certa negação da sexualidade.

\section{2 - Os monstros - os homens, o sexo, os assuntos proibidos}

Neste conto de Alice não fica claro que existem assuntos tabus, dos quais não me sinto segura em tratar, ou que me soem como algo inacessível ou proibido. Por mais que eles estivessem explícitos durante a escrita da autobiografia, em Alice aparecem de forma subjetiva, como na verdade os sinto.

A maneira como a sexualidade foi tratada durante minha infância e a relação com o masculino nas dinâmicas familiares construíram em mim uma certa tensão ao me deparar com o 
assunto. A naturalidade com que minha mãe abordava a questão e a forma quase displicente com que falava a uma criança sobre sexo e homens desenvolveram em mim um tabu. Um assunto proibido, não em discurso. Mas na vida.

No conto de Alice, o arquétipo masculino é simbolizado pelo Sátiro, que traz em si a figura monstruosa dos assuntos proibidos. Assuntos que se referem não só à sexualidade, mas ao gênero; ao papel social que de forma coletiva foi se construindo acerca da persona que eu assumiria diante do grupo ao qual pertencia. A escola, a rua, a praia e todas as experiências vividas nessa fase quase determinam as escolhas dos caminhos que devo prosseguir ao longo da vida. No entanto, nada é consciente.

Aqui podemos tratar de duas questões: o Sátiro enquanto representação do masculino e da descoberta da sexualidade em minha vida e assim representados em Alice; e o papel da escola, enquanto núcleo formador de gênero relatado na autobiografia.

Quanto ao Sátiro, partimos da definição dada por Cohen (2000), como uma projeção:

“o monstrum é, etimologicamente, 'aquele que revela', 'aquele que adverte' (...) o monstro significa algo diferente dele: é sempre um deslocamento" (p.27) (...) eles são híbridos que perturbam, híbridos cujos corpos externamente incoerentes resistem a tentativas para incluí-los em qualquer estruturação sistemática. $\mathrm{E}$, assim, o monstro é perigoso, uma forma - suspensa entre formas - que ameaça explodir toda e qualquer distinção (p.30) (...) O horizonte no qual os monstros moram pode muito bem ser imaginado como a margem visível do próprio círculo hermenêutico: o monstruoso oferece uma fuga de seu hermético caminho, um convite a explorar novas espirais, novos e interconectados métodos de perceber o mundo (p.31). (...) "O monstro é a diferença feita carne; ele mora no nosso meio. Em sua função como Outro dialético ou suplemento que funciona como terceiro termo, o monstro é uma incorporação do Fora, do Além - de todos aqueles loci que são retoricamente colocados como distantes e distintos, mas que se originam no Dentro. Qualquer tipo de alteridade pode ser inscrito através (construído através) do corpo monstruoso, mas, em sua maior parte, a 
diferença monstruosa tende a ser cultural, política, racial, econômica, sexual”. (p.32)

O monstro é, então, a novidade. Aquele que representa a conexão entre mundos. A personificação do processo de metamorfose. É Kafka, em sua mais pura essência. O monstro é aquele que nos devora enquanto indivíduos e regurgita o assombroso, o ilegível, o incompreensível, o desconhecido. Como cantado por Gilberto Gil na canção "A novidade” (Gilberto Gil, Herbert Vianna, João Barone,1986), “A novidade era a guerra entre o feliz poeta e o esfomeado". A guerra entre o existir e o não existir, ausência e presença, desejo e realização, morte e vida.

O Sátiro é o monstro que abre as possibilidades, descortina mundos, explica a Alice sobre as coisas da vida, ele a conduz a novos caminhos. Ele representa o caos, o corpo nu, o corpo-animal, o corpo-vida, o corpo-poesia, o corpo-música, o corpo-arte, o corpo-política.

São muitas alegorias que Alice deve dar conta nesse encontro:

"A destrutividade do monstro é realmente uma desconstrutividade: ele ameaça revelar que a diferença tem origem no processo e não no fato (e que o 'fato' está sujeito à constante reconstrução e mudança) (...) As mesmas criaturas que aterrorizam e interditam podem evocar fortes fantasias escapistas; a ligação da monstruosidade com o proibido torna o monstro ainda mais atraente como uma fuga temporária da imposição. Esse movimento simultâneo de repulsão e atração, situado no centro da composição do monstro, explica, em grande parte, sua constante popularidade cultural, explica o fato de que o monstro raramente pode ser contido em uma dialética simples, binária (tese, antítese... nenhuma síntese). Nós suspeitamos do monstro, nós o odiamos ao mesmo tempo que invejamos sua liberdade e, talvez, seu sublime desespero" (Cohen, 2000, p.45 e 48) 
Da união entre Alice e o Sátiro há uma transformação em Alice. O Sátiro a leva ao encontro de si em um novo lugar, o de mulher-bruxa. Alice não era mais fada, não era mais ninfa. Alice agora é bruxa.

O simbólico presente nesta personificação representa o arquétipo da grande mãe em seu lado sombra. Esse rico encontro foi seguido de um abuso; não foi profano, foi violência. Esta rede de levar a outros mundos foi também uma rede de captura, de prisão. Alice sente culpa pela metamorfose sem acolhimento, pela transformação de ser-menina em ser-mulher sem o cuidado necessário ou por ela imaginado. Assim, se inicia a saga de Alice mulher.

\section{3 - Convite à jornada - o processo de iniciação}

Este é o primeiro conto da Alice na fase adolescente. A jornada da infância é encerrada, o afastamento do núcleo familiar vai se dando de maneira cada vez mais intensa. É dada a fase de iniciação no monomito, momento em que o indivíduo inicia sua busca por si, passando por diversas "provas" até que alcance a iluminação, quando o sujeito passa a ser "aquele que

aprende. À medida que ele progride, na lenta iniciação que é a vida" (Campbell,1997, p.117)

Aqui, os encontros com os mestres são dados em suas iniciações na vida adulta. Para Mestre Alcides, a iniciação veio, como relatado por ele, pelo trabalho: "Antes de eu vir para São Paulo, com onze anos, doze anos, treze anos eu já sai de casa para trabalhar também, eu trabalhei em Goiás muitos anos. Eu e meu tio, meu tio Chico que é esse que é capitão do terno que fez noventa anos. Mas na minha época, nas cidades apareciam os 
caminhões tipo boia-fria, ligava o microfone, chamava para trabalhar, a gente ia e ficava seis meses, sete, oito meses fora da cidade. Então, eu sozinho saí muito para trabalhar. Eu nunca fui de ficar naquele lugar ali, e meus irmãos...Eu tenho irmãos que eu praticamente não conheço, porque eu tenho irmão de quarenta anos de idade, eu tenho sessenta e sete, eu nunca vivi com ele porque quando ele nasceu eu não estava em casa, saía de casa, voltava um ano, dois anos depois. Em casa, eu ficava um semestre, saía, ficava mais um ano, dois anos fora..."

O afastamento da casa, da família com seu berço de tradição se dá de forma mais abrupta, com um distanciamento geográfico e temporal. O processo de iniciação, claramente marcado pelo mundo adulto do trabalho, enquanto que para mim e Matheus essa iniciação se dá de forma mais lenta e tardia. Matheus nos conta: "Primeiro e segundo ano, aí eu fui para o Instituto de Educação, ali fui até o científico, hoje colegial, mas antigamente era científico. Era dividido em científico, clássico e normal. Você escolhia se você queria fazer engenharia, você ia fazer exatas ou ciências, mais geral era o científico. Se você queria área de humanas, você ia para o clássico. Se quisesse, dar aula, por exemplo, você ia para o normal. Normal para formar professores, normal. E eu fiz o científico, porque eu gostava de biologia. Mas era muito nebuloso naquela época, não tinha definido o que eu ia fazer, mesmo a biologia, era meio distante porque não tinha aqui em São Carlos."

Eu e Matheus ainda nos preparávamos em planos para o futuro na vida adulta. Nossa condição ainda era de alunos, filhos mantidos pelos pais. Nenhum dos mestres faz referência à vida afetiva ou social desta época. 
Ao citar a escola, Matheus traz algumas informações sobre a organização dessa instituição enquanto formadora intelectual. Discutir o papel da escola nesta fase é importante por este aspecto e pela sua função social. Eu estudei em escola pública no Ensino Médio, assim como Matheus, porém, quando eu a frequentei, entre os anos 1992 e 1993, o ensino público já se diferenciava muito do privado, em qualidade de ensino, como fica claro em meus relatos autobiográficos. A escola pública, tal como hoje, assumia pouco o papel de formadora intelectual ou crítica, estando, prioritariamente, como lugar das relações sociais. A instituição escolar secundária não me deu suporte para ingressar no ensino superior, como ofereceu para Matheus, no entanto, assumiu um papel importante de formação identitária:

"O papel que a Escola assume nesse cenário pode ser visto, não apenas como importante, mas como estratégico na medida em que se constitui num local potencialmente explicitador e questionador das complexas formas pelas quais as identidades culturais são construídas, articuladas, experienciadas, transgredidas e rearticuladas no âmbito do social" (Furlani, 2007, p.271).

A representação da minha relação com o masculino em Alice, se dá por meio da figura do Sátiro, um "monstro", que pode ter se dado não só por questões pessoais, mas pela própria construção social da ideia de sexualidade na ambiente escolar. Furlani (2007, p.282), afirma que:

"É quase impossível não deixar de imaginar o quanto essa lógica estaria permeada nas representações culturais que a 'sexualidade' tem adquirido nas sociedades ocidentais. Ela mesma (uma vida sexual ativa e diversa) seria vista como uma 'dimensão humana monstruosa' quando analisamos a história, que por séculos, parece ter privilegiado muito o sexo reprodutivo confinado ao casamento cristão ou a castidade. Portanto, expressar uma ampla vida sexual, concebê-la em todas as fases da vida, admitir práticas sexuais distintas daquelas voltadas à reprodução, considerar a existência de uma subjetividade no prazer humano, entre outras coisas, tornariam a sexualidade, inquestionavelmente, 'monstruosa'." 


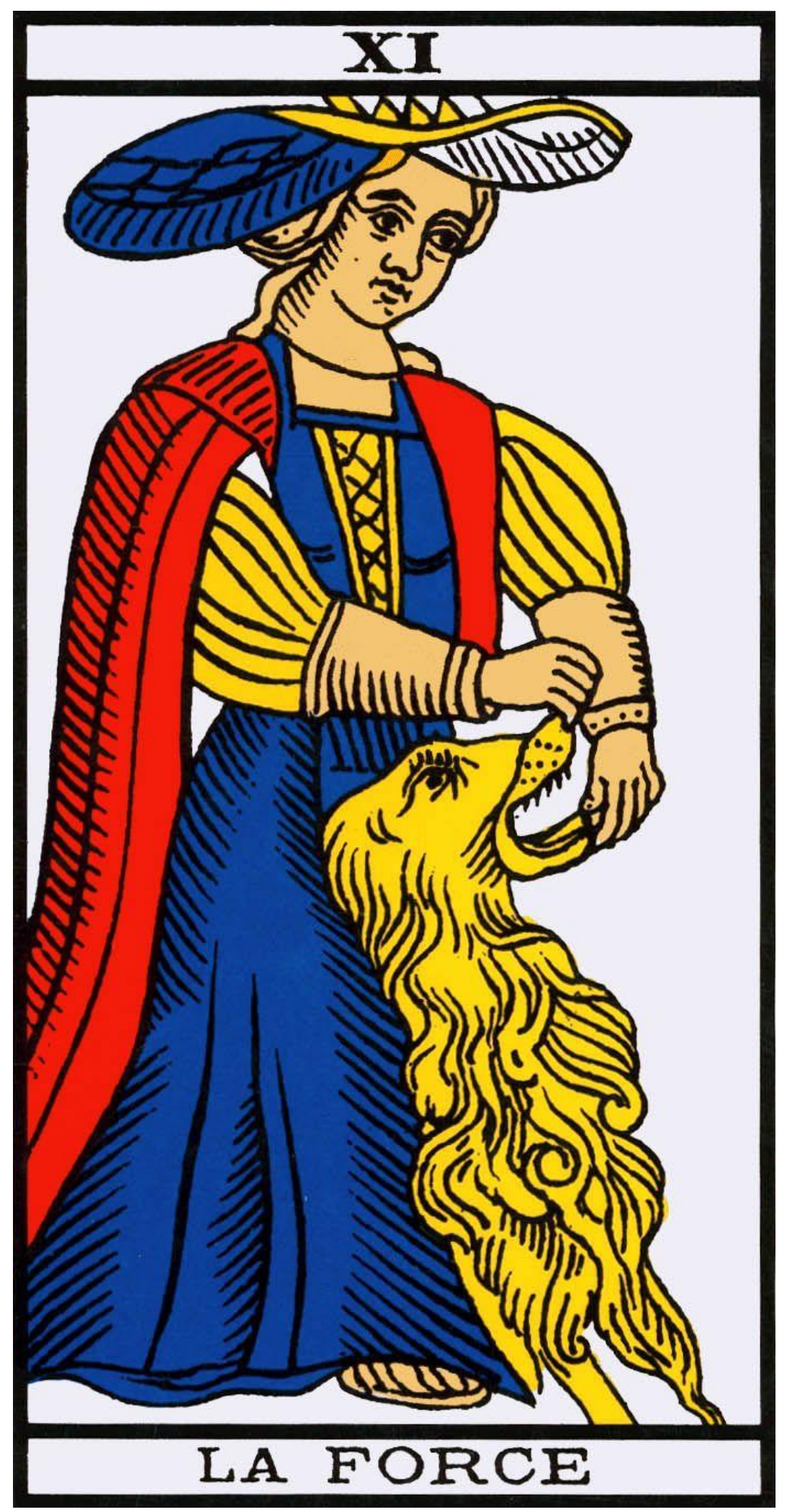




\section{1 - Alice na Escola de Bruxas}

Depois do Sátiro, se fazer de fada ficou fácil para Alice, dificil mesmo, era lidar com aqueles dentes afiados que Castigo havia ganhado. Alice decidiu que seria mais fácil se pudesse se juntar a outras bruxas e assumir de vez sua identidade. Aquele ar de fada fazia parte dela, mas fazer-se fada o tempo todo a cansava.

Alice soube de um lugar muito mágico, a que chamavam de Escola de Bruxas. Era longe e para se chegar nele, era preciso vencer muitas provas. A tal escola ficava no fundo de um velho bosque, um bosque onde ninguém andava, só aqueles que eram fortes.

A tradição dizia que forte era aquele que atravessava os cinco obstáculos do caminho escuro. Vencer a escuridão era o primeiro deles.

A única forma de vencer a escuridão era conseguir andar pelo bosque com os olhos fechados. Alice era craque em imaginar mundos iluminados e não foi difícil para ela se pôr a caminhar, imaginando um bosque claro e colorido, cheio de cheiros e mistérios.

O segundo obstáculo era escolher a história certa. No bosque sombrio havia árvores contadoras de histórias, mas era preciso que se escolhesse a história do tamanho do seu coração. Alice ficou um pouco confusa! Titubeou entre três ou quatro histórias, mas conseguiu encontrar aquela que cabia em seu peito, medindo-a com a palma de sua mão.

O terceiro obstáculo era não ter medo. Alice quase não venceu esta prova, porque apesar de caminhar com firmeza, 
confundia a sensação da sombra das árvores com a sombra do dragão. Alice sabia que se ele aparecesse por ali, ela não conseguiria.

O quarto obstáculo era saber andar só. Alice sabia andar só e para ela não era nenhum problema. Mas havia Castigo e ele nunca se distanciava dela. Alice teve que fazer um esforço danado para esconder castigo em sua mochila. Seus dentes ficaram para fora, mas ninguém percebia que eram dentes... pensavam que eram uma armadura de proteção.

O quinto obstáculo era voar... Alice ficou tão feliz com a descoberta deste obstáculo, que suas asas, que há muito tempo não a faziam voar, abriram em luzes e cores, transbordando brilho e a fazendo alçar num voo nas alturas.

Alice fora aprovada! Estava pronta para Escola de Bruxas. 


\section{1 - Pés na estrada - o início da grande jornada}

Este conto de Alice se refere ao período entre o fim do Ensino Médio e a entrada na universidade. Nesta fase eu vivia dramas internos com relação aos afetos que borbulhavam em mim com a descoberta do eu-mulher. Muitas fantasias sobre os assuntos proibidos, sobre o sexo e a culpa que eu carregava por ter vivido muito precocemente minha primeira experiência sexual, me transformaram em uma falsa representação da "garota ideal", ou da construção de uma persona forjada, calculada a partir de modelos sociais fortemente impostos.

Eu sabia o que esperavam de mim e o que tinha a apresentar não correspondia às expectativas externas. Internamente, alimentava um profundo ódio pelo masculino e tudo que ele representava, enquanto presente e passado. No entanto, acreditava que este mesmo masculino, poderia ser a salvação para a minha vida infeliz.

Nesta fase, vivi meu primeiro relacionamento longo. Eu tinha 16 anos e ele 22. Foi sem dúvida, o homem mais machista e mais opressor com quem já me relacionei. Ele dizia que havia se apaixonado por mim porque meu rosto lembrava o da Virgem Maria, a mulher com quem ele sonhara em casar. Eu, que já havia me acostumado a viver o personagem da "virgem santa", assumi o papel e teatralizei com muito empenho nosso romance.

Na nossa primeira vez, precisava fazê-lo acreditar que eu era virgem. Não foi difícil. Eu já havia sido virgem antes e lia muito sobre as primeiras relações sexuais das garotas adolescentes em revistas femininas. Sabia como representar o papel. Porém, ele não acreditou. Foi uma surpresa para mim. 
Fiquei me questionando sobre o que eu teria feito de errado, onde não havia personificado o papel ou em que momento saí do personagem. Em uma conversa, ele explicou: "Toda menina sangra na primeira vez!”

Aquela afirmação me surpreendeu. Até os mais desavisados sabem que isso não é verdade e eu mesma era a prova disso. No entanto, tentar explicar foi inútil. Ele acreditou em toda a performance, mas o detalhe do sangue foi maior. Como acreditar em uma garota que não sangra?

Depois de meses afirmando e reafirmando que eu era virgem e que nem sempre meninas virgens sangram em sua primeira relação, desisti. Contei para ele "meia verdade", contei para ele da minha primeira vez, mas disse que foi só uma vez. Disse do horror da experiência de um sexo forçado, que sentia culpa, que sentia repulsa, que aquela situação havia me machucado, mas que não houve outras vezes, foi só uma vez, um estupro.

Ele me perdoou.

Ele me perdoou pelo estupro que eu havia sofrido.

Minha repulsa por homens aumentou, mas permaneci na relação porque aquele relacionamento era sempre uma desculpa para eu ficar fora de casa. Ele me traía com sua ex-namorada. Moça que foi agredida por ele física, emocional e moralmente durante anos, mas que o amava. Eu sabia, mas não me incomodava. $\mathrm{O}$ que me incomodava era o fato de ele mentir para mim, de não perceber que não era tão ingênua como ele gostaria que eu fosse.

Foram dois anos de relacionamento abusivo. 
No último ano desta relação, estava muito empenhada em passar no vestibular. Fazia meu segundo ano de cursinho, estudava mais de oito horas por dia e sonhava pelo momento em que estaria liberta de toda aquela vida infeliz que eu vivia. Havia armado um plano de estudar fora, mantendo assim um vínculo financeiro com a família, mas cuidando sozinha de mim.

Em 1996, entrei no curso de Ciências Biológicas na PUC-São Paulo, campus Sorocaba. Não deu USP. Apesar de ter chegado na segunda fase, era muito difícil para mim.

Antes de focar nessa Alice, é preciso retomar o último parágrafo do conto anterior, que nos traz elementos que dialogam com as experiências simbolizadas aqui. $O$ conto termina com o seguinte parágrafo: “Arrependida, Alice passou a se preocupar com o dragão... O seu medo fez Castigo ganhar dentes afiados, que agora a machucariam cada vez que ele crescesse ao seu lado."

Até esse momento da escrita, Castigo e o dragão ainda são incógnitas para mim. As leituras vão trazendo inúmeras possibilidades do que esses personagens podem representar. Sempre contemplando a dualidade simbólica, já sabemos que nenhum deles representa isoladamente o bem ou o mal.

Três aspectos são importantes nesse parágrafo. Alice já se preocupava com o dragão, porém parece haver um "novo" preocupar-se, um algo além do que já existia - a existência de um segredo que seria escondido do dragão. O sentimento de medo é percebido pelo dragão, que reage dando dentes afiados a Castigo, porque o cachorro está ligado ao dragão e não a Alice - o cachorro só cresce quando mudam os humores do dragão. Este crescer só atrapalhava Alice em seu caminhar, porém agora ela é 
ferida quando isso acontece. Ou seja, o dragão reage ao medo de Alice e se reflete em Castigo.

No conto atual, Alice fica cansada em representar algo que não é. Ela não quer mais o papel de fada e resolve partir para a busca de assumir-se bruxa. Ao ler esse conto, o associei à história de Vasalisa, um antigo conto russo sobre a iniciação da mulher e dos instintos femininos da mulher iniciada (Estés, 1999).

Sobre esse conto, Estés (1999) faz uma análise sobre as tarefas que devem ser cumpridas para que a mulher alcance a iniciação. São elas: permitir a morte da mãe boa demais; denunciar a natureza sombria; navegar nas trevas; encarar a megera selvagem; servir o não racional; separar isto daquilo; e perguntar sobre os mistérios.

Nesse conto de Alice, vemos o desejo do abandono da imagem da fada, que pode assumir em Alice a representação da "mãe-boa-demais". Sobre a denúncia da natureza selvagem, Estés (1999) explica:

"Criar o melhor relacionamento possível com as piores partes de si mesma. Deixar acumular a tensão entre quem se aprendeu a ser e quem se é realmente. Trabalhar, afinal, no sentido de deixar morrer o velho self para que nasça o novo self intuitivo.” (p. 64).

O desejo de Alice em assumir-se como realmente é e a busca pelo caminho que a levaria ao encontro de suas semelhantes.

Alice fica sabendo sobre uma Escola de Bruxas, num bosque distante, onde ninguém andava. Para chegar à escola, Alice deve realizar cinco tarefas: vencer a escuridão, escolher a história certa, não ter medo, saber andar só e voar. 


\section{2 - O caminho - a realização das tarefas iniciatórias}

Encontramos um grande diálogo entre esse conto de Alice e as fases de iniciação descritas por Estés (1999), simbolicamente contadas na história de Vasalisa.

A primeira tarefa de Alice foi vencer a escuridão.

"A única forma de vencer a escuridão era conseguir andar pelo bosque com os olhos fechados. Alice era craque em imaginar mundos iluminados e não foi difícil para ela se pôr a caminhar, imaginando um bosque claro e colorido, cheio de cheiros e mistérios"; o que corresponde à tarefa de "navegar nas trevas", observada em Vasalisa.

Alice cumpre a tarefa fechando seus olhos. Se não há olhos físicos abertos que direcionem o andar, podemos supor que Alice utiliza de seus olhos intuitivos, olhos que agucem a imaginação e permitam a ela criar um caminho mais confortável para que possa atravessar a escuridão que, segundo Estés (1999), refere-se ao aventurar-se a penetrar no local da iniciação profunda.

Vasalisa é uma menina que recebe da mãe, no leito de morte, uma boneca. Esta boneca simboliza um legado:

“A boneca de Vasalisa pertence às provisões da Velha Mãe Selvagem. As bonecas são um dos tesouros simbólicos da natureza instintiva. No caso de Vasalisa, a boneca representa vidacita, a pequena força da vida instintiva que tanto é feroz quanto resistente. Não importa o problema que estejamos enfrentando, ela leva uma vida oculta dentro de nós (...) A boneca representa os homunculi simbólicos, a pequena vida. É o símbolo do numinoso e está sufocado nos seres humanos. Ela é um facsímile pequeno e luminoso do Self original (...) Dessa forma, a boneca representa o espírito interior das mulheres: a voz da razão, do conhecimento e da conscientização íntima”. (Estés, 1999, p.67,68)

Ora, mas Alice não recorre a nenhuma boneca, elfo ou anão em sua caminhada. Ela confia em si e em seu poder de 
enxergar além do que pode ou não ser visto. Ela confia na própria intuição. Alice já havia permitido a morte da moça frágil e ingênua que havia sido e se sentia pronta para confiar em sua força e em seus próprios sentidos interiores.

No entanto, uma das tarefas de Alice era saber andar só e sobre esta tarefa não encontrei um diálogo direto com as fases de iniciação. Alice não pode andar só porque carrega consigo Castigo. Castigo é um cachorro que ela herdou do dragão. Foi um presente que dragão lhe deu antes de desaparecer. Alice, então, o coloca em sua mochila e só seus dentes ficam para fora, de forma que se assemelhem a um escudo - e um escudo protege.

Durante as investigações nas obras: "As mulheres que correm com os lobos" (Estés, 1999), "O herói de mil faces" (Campbell, 1997) e "Os símbolos de transformação" (Jung, 1963), fui construindo uma nova leitura para Castigo. Campbell (1997) fala sobre o guardião do limiar, aquele que "vigia os limites estabelecidos", no sentido de proteger e ao mesmo tempo colocar limites sobre o que deve o ou não ser experimentado, ou o novo a ser vivido.

Estés investiga a figura do cachorro por meio da análise do conto "Manawee".

"É o self-cão que aprende a superar as seduções superficiais e a reter os conhecimentos mais importantes. É a natureza canina de Manawee que tem a tenacidade e a audição apurada, os instintos para se enfiar por baixo de paredes e para encontrar, perseguir e resgatar ideias valiosas (...) Os cães são os mágicos do universo. Com sua simples presença, eles transformam o mau humor em sorrisos, as pessoas tristes em pessoas menos tristes. Eles geram relacionamentos. Como na antiga epopéia da Babilônia "Gilgamesh", na qual Inkadu, o homem-animal peludo, contrabalança Gilgamesh, o rei excessivamente racional, o cachorro é todo um lado da natureza dualista do homem. Ele é a natureza dos bosques, aquele que sabe rastrear, que sabe porque pressente o que é o quê. (1999, p.91 e 93)" 
O cão de Manawee parece ter a mesma relação simbólica da boneca de Vasalisa, porem há ainda mais um elemento de ligação entre a figura do cão e esse conto de Alice: Vasalisa ganha a boneca de sua mãe falecida, aquela que não estará mais presente em sua vida; a boneca é a herança da intuição feminina. Alice herda Castigo do dragão, que no primeiro conto de Alice, descrevo como uma representação simbólica da minha mãe.

Esta representação do dragão foi descartada por parecer simplista e superficial, no entanto, ao transformar a autobiografia em contos de Alice, criava imagens de figuras que pudessem representar alegoricamente a história ao qual me referia e, sim, a relação que eu estabelecia era direta. Eu realmente queria falar da minha mãe ao citar o dragão.

Jung (1962), ao analisar os símbolos de transformação ligados à mãe e ao renascimento, cita o dragão como imagem negativa da mãe, da mãe-devoradora, castradora da libido ou como representação simbólica do temor e das consequências de infringir o tabu (pp. 226 e 272). Ainda que o dragão que pertence a esta configuração ocidental seja radicalmente diferente dos atributos simbólicos do dragão no oriente benfazejo, protetor, associado à prosperidade e à ancestralidade.

Dragão e Castigo podem ter inúmeras outras leituras ou serem em si representações ainda mais subjetivas dos elementos de composição do self; mas não se pode negar que parece mesmo haver uma relação de Castigo como a intuição feminina herdada por Alice. Uma intuição que já não é tão selvagem porque traz valores e é carregada de castração de uma mãe "devoradora". 
Assim simbolizada pelos dentes de castigo que crescem após o encontro de Alice com o Sátiro.

Castigo é o instinto, é a proteção, é a boneca de Vasalisa. Mas é também aquele que impõem limites, o guardião:

"É melhor não desafiar o vigia dos limites estabelecidos. E, no entanto, somente ultrapassando esses limites, provocando o outro aspecto, destrutivo, dessa mesma força, o indivíduo passa, em vida ou na morte, para uma nova região da experiência" (Campbell, 1997, p. 85).

Por isso, talvez Alice tenha essa relação de amor e ódio com Castigo. Ela sabe de sua importância, porém sofre com as renúncias que deve fazer em função dos limites por ele estabelecidos. Podemos, então, concluir que ao colocar Castigo em sua mochila, ao acoplá-lo em seu corpo e transformá-lo em escudo, Alice cumpre uma das fases de iniciação não explícitas entre as tarefas de Alice, a denúncia da natureza sombria:

"Vivenciar diretamente a própria natureza sombria, especialmente os aspectos exploradores, ciumentos e rejeitadores do self (a madrasta e suas filhas). Incorporar esses aspectos. Criar o melhor relacionamento possível com as piores partes de si mesma. Deixar acumular a tensão entre quem se aprendeu a ser e quem se é realmente. Trabalhar, afinal, no sentido de deixar morrer o velho self para que nasça o novo self intuitivo" (Estés, 1999, p. 64 e 65)

A segunda tarefa de Alice era "escolher a história certa":

"No bosque sombrio havia árvores contadoras de histórias, mas era preciso que se escolhesse a história do tamanho do seu coração. Alice ficou um pouco confusa! Titubeou entre três ou quatro histórias, mas conseguiu encontrar aquela que cabia em seu peito, medindo-a com a palma de sua mão". Podemos aqui, encontrar um diálogo com a sexta fase da iniciação: "separar isto daquilo". 
Ao escolher a história do tamanho do seu coração, Alice deve ter ouvido muitas árvores e foi com o tato que ela escolheu a que cabia em seu peito, em seu coração. Alice usou mais uma vez sua intuição. Foi preciso usar sentidos não físicos para superar esse obstáculo. Vasalisa, em sua história, precisou separar sementes de papoulas do estrume e, para tanto, precisava de suas mãos. Mas foram as mãos da boneca que realizaram esta tarefa, as mãos da intuição.

O terceiro obstáculo de Alice: "era não ter medo". "Alice quase não venceu esta prova, porque apesar de caminhar com firmeza, confundia a sensação da sombra das árvores com a sombra do dragão. Alice sabia que se ele aparecesse por ali, ela não conseguiria". O afeto que liga Alice ao dragão é o medo e ela já havia provado das consequências deste sentimento ao ver crescer dentes afiados em Castigo. E, por isso, para penetrar nesse local de profunda iniciação, seria preciso que ela enfrentasse o medo e, por consequência, o dragão que carregava dentro de si.

Vejo aqui, uma relação com a fase "encarar a megera selvagem". Se Alice carrega em si todos estes arquétipos com os quais constela ao longo dos contos, o dragão é parte de si. A "mãe-devoradora" está dentro de Alice. Quando tomou a decisão de deixar de ser fada, de deixar morrer a "mãe-boa-demais"; de deixar-se encontrar com seu lado selvagem, Alice precisava enfrentá-lo e assim se deu por meio da superação do medo de atravessar o bosque. Quando decidi me dedicar aos estudos para partir em direção a uma nova vida, tive que buscar forças, principalmente para abandonar o papel de "moça virgem" de "menina obediente", como colocado por Estés (1999) para 
"permitir que a criança frágil e boazinha em excesso vá definhando ainda mais." (p. 69)

A quinta tarefa da Alice era voar. Alice não teve dificuldade em vencer esta prova, foi preciso apenas recorrer às suas asas, ao seu dom, à sua natureza, que no momento soprava a seu favor. Alice feliz, voava. Bachelard (2001), na sua poética sobre o ar, nos diz do voo como a representação do desejo de liberdade "Teu voo é uma libertação; Voando, a volúpia é bela". (p. 21). Superar esse obstáculo seria também, a conquista da liberdade, a conquista para o outro mundo. Não encontrei relação com algumas fases de iniciação da mulher selvagem, descritas por Estés (1999), mas, ainda assim, esse conto de Alice relata um processo iniciático completo. $\mathrm{O}$ início de um novo caminho que não teria mais retorno.

\section{3 - O encontro com os mestres}

Nesse conto de Alice, há encontro com Matheus e Mestre Alcides. Agora as histórias vão se misturando, no entanto, não seguem mais um padrão etário. Durante a infância consegui manter uma linha próxima entre fatos que nos ligavam nas mesmas idades. Mas já no fim da infância, Mestre Alcides faz sua iniciação, enquanto eu e Matheus seguimos em outras fases.

Cada sujeito tem seu tempo, sua hora, sua trajetória, sua jornada. As vidas vão se dando a cada um de formas únicas e nossos encontros vão ganhando contornos próprios neste bordado. As três linhas que começaram alinhavando a borda do tecido vão ganhando outros traços e desenhando um cenário 
mais diverso. Ou melhor, cada linha vai agora bordando seu próprio conto, embora a trama ancestral seja a mesma.

Mestre Alcides, que já havia saído de casa e vivido muitos mundos entre o fim da infância e o início da adolescência, nos conta em seu relato sobre sua vinda para São Paulo, onde, de fato, iniciou a trajetória que o levou ao nosso encontro.

Sobre essa fase, nos conta: "Eu não vim sozinho para cá. Na verdade, as minhas irmãs como empregadas domésticas, então, vieram com as patroas para cá, lá de Minas, trabalhar, porque essas patroas fazendeiras tinham casa no Rio de Janeiro, aqui em São Paulo, enfim. Aí, elas traziam as filhas dos capatazes como empregadas delas e a minha irmã mais velha, que veio para são Paulo com uma dessas patroas, resolveu sair da casa da patroa e arrumar um outro emprego em outra casa aqui. Então, ela alugou um cortiço (...) Nos quartos, então, a minha irmã mais velha falou: 'Olha, eu estou num quarto e não posso colocar você, se você quiser ir para lá, eu vou alugar um outro maior'. Tudo isso era novo para mim, mas eu me adapto em tudo, até hoje não tenho dificuldade (...) Para um lado do novo de aprendizagem, até voltado para o meu lado espiritual, eu acho que tudo é espiritual, até o sofrimento, não é só alegria ou prazer, até o sofrimento é espiritual e meus irmãos, a maioria, não saíram de lá, eu sempre achei esse lugar muito pequeno, por isso que eu saia muito... eu achava muito pequeno, eu sempre queria sair, queria coisa grande, queria lugar diferente, mesmo que fosse com garoa"

Em outro momento da entrevista, Mestre Alcides relata: "Saí de uma cultura, lá do interior dos congados, das nossas danças, diferente, para vim para São Paulo, numa cidade 
grande, ainda naquela época, terra da garoa, que não tinha lá em Minas, nunca tinha visto garoa. Já em 1967 eu entrei na Universidade de São Paulo para trabalhar e, aí, houve essa quebra rígida mesmo, abrupta mesmo, agressiva mesmo, de mudança cultural. Aí, eu fui morar na Bela Vista, na Rua Major Diogo, num cortiço, naquela época 'há vagas para rapazes e moças', então você chega com a malinha, já bate lá e já fica morando ali, sem conhecer ninguém, enfim... Primeiro eu vim trabalhar na construção civil e dentro do cortiço mesmo que eu conheci uma pessoa que trabalhava na USP que falou: 'Olha, lá na universidade tá precisando servente'. Eu pensei que fosse servente de pedreiro porque na construção civil eu trabalhava servente de pedreiro, só que aqui no Crusp, na época, chamava Issu, Instituto de Saúde Social, Oseas, que hoje é SAS. Era faxineiro, serviços gerais. Eu fiz o concurso, passei, fui bem classificado e levei um outro choque porque em Minas não tem essa profissão de faxina, de servente para limpar apartamento do Crusp para os estudantes morarem. Eu levei um outro choque, falei: 'Ah, mas eu vim de Minas para fazer faxina, trabalhar aqui tirando pó de mesa, estendendo cama?"(...) Os estudantes recebiam o apartamento limpinho, com roupa de cama trocada, fronha trocada, lençol trocado, tudo trocadinho... Limpar, passar o pano de pó nos armários, em tudo, enfim, isso era diariamente, tinha que ser feito isso, entendeu? E eu tive que fazer um estágio de quinze dias, fazendo isso, ainda para ser aprovado tinha um fiscal, um funcionário mais velho para ver se eu estava fazendo isso tudo direito e eu, quando falou parte financeira, eu gostei porque era bem maior do que na construção civil, trabalhando sábado, enfim, hora 
extra... Eu me empolguei, aí, fiquei, mas eu sempre fui muito focado no meu objetivo de vida. Falei: 'Eu vou entrar nisso aqui, mas eu não vou ficar nisso, não subestimando, nem nada, mas eu não vou ficar'. Então numa época eu trabalhei e em 67, 68 foi a invasão militar no Crusp, aí acabou essa questão das limpezas, eu fui trabalhar com um coronel do GK 9o, chamado Coronel Vin. Ele virou meu chefe e, ai, já fui para parte administrativa porque os estudantes foram expulsos todos do Crusp, o Crusp fechou, eu fui trabalhar na área administrativa. Foi quando mudou a parte médica da faculdade de medicina da doutor Arnaldo para o Crusp, aí, montou um ambulatório, um médico, enfermeira e eu fui indicado para poder organizar os arquivos das fichas dos estudantes da Faculdade de Medicina.Aí, eu já fiquei no escritório, fiquei trabalhando na área de saúde, já como atendente. Depois, por lei, a gente foi contratado como administrativo. Fiquei muito tempo nessa área."

Mestre Alcides, em seu relato, também nos conta sobre suas "tarefas" iniciáticas; sobre vencer o medo, adentrar ao bosque escuro, encarar a megera selvagem, permanecer com ela e confiar em sua intuição, preparando-se para uma nova vida. $\mathrm{O}$ bosque escuro era a cidade grande, aquela que engole sem medo. Fria e úmida, diferente do calor e da aridez de onde ele provinha e dos afetos de sua "mãe-boa-demais", do acalento de sua ancestralidade. Mestre Alcides vence o seu medo de torna-se o que julgava ser menos do que merecia, menos do que podia ser, aceitando uma condição provisória até alcançar seu objetivo maior. 
Mestre Alcides e eu bailamos juntos nessa busca pelo maior. Eu também achava que aquele lugar onde eu vivia era pequeno demais para mim, que havia outros mundos, outros oceanos e outras histórias. Que eu podia voar mais alto e para isso deveria buscar um lugar que fosse do meu tamanho. Mestre Alcides já era meu mestre, sem nem mesmo nos conhecermos.

Matheus, também nos conta sobre sua iniciação, o momento em que teve que abandonar o lugar confortável e acolhedor para crescer e encontrar seu eu-maior. Em seu relato: "Entrei na (universidade) Barão de Mauá, uma particular. Tinha (biologia) na USP, mas não consegui entrar. Mas na época foi muito traumática para mim, essa foi a parte mais triste da minha vida, meu pai ficou doente. Ele tinha uma lojinha, foi obrigado a se aposentar porque se endividou. Ele construiu uma casa, até hoje minha mãe mora lá ... na caixona Federal e tinha um reajuste mensal, naquela época, chamado correção monetária e os juros eram violentos e ele não conseguia pagar a prestação da casa aí, ele teve que sair das lojas Pernambucanas, sair para receber o fundo de garantia, para poder pagar as dívidas. Ele fez um acordo lá e saiu e ele ficou muito, assim, porque ele queria aposentar porque ele fazia, acho que 30 anos que estava nas Pernambucanas, se ele se aposentasse lá, por tempo normal, ele ia ganhar um prêmio, sabe? Tinha uma época em que ele era um dos vendedores mais atuantes, quando ele faleceu eu fui fazer inventário e tal, eu fui tirar a documentação dele das Pernambucanas, nos últimos dez anos que ele trabalhou lá, ele era o primeiro vendedor, o que mais vendia, estava sempre no topo, ele era muito atencioso com todo mundo, era uma pessoa muito bacana. Por causa da 
dívida, enfim, uma série de coisas, ele ficou doente, com câncer, câncer no intestino e fez várias cirurgias, né, mas ele não conseguiu e faleceu. E nessa época a lojinha, ele passou em meu nome, eu fui emancipado, não podia... sofri o processo de emancipação (...) não tinha idade para assumir a loja, mas para poder conciliar as coisas, eu fui emancipado, e eu tive que cuidar da loja um tempo, fiquei um tempo com a lojinha. Não tinha muito a ver comigo porque comércio. (...) Tinha 17 anos e eu tive que trancar a faculdade, parei de estudar um tempo, fui cuidar das coisas da família, minha mãe em depressão profunda, eu era mais velho, os irmãos pequenos... tive que cuidar da família. Eu parei de estudar e fui tocar durante uns 3 anos, aí nós vendemos a lojinha e minha mãe quitou todas as dívidas. Nós saímos da casa, fomos morar com a minha avó e alugamos a casa para poder entrar uma renda para terminar de pagar tudo. Depois que pagou tudo, nós voltamos para casa. Aí, minha avó também ficou doente, morreu minha avó, morreu meu avô, foi assim... em três, quatro anos, morreu meu pai, minha avó e meu avô, o pai da minha mãe... foi a época mais dificil. Eu não sabia o que fazer, ficava preocupado com os irmãos que eram pequenos ainda, aí, eu entrei na aqui na Federal (faculdade), licenciatura em Ciências, em 1970".

A iniciação de Matheus se deu por perdas e caminhos mais obscuros, pelas mortes reais de entes queridos, pela sua própria morte como menino, pela necessidade de encarar e assumir o papel de homem no cuidado com a família. Matheus adiou seus sonhos da universidade e enfrentou as adversidades da vida. Sua morte-vida-morte se deu também no plano do real. Sua iniciação foi o luto e a força para assumir seu novo lugar de ser. Porém, 
Matheus não se desvinculou dos seus sonhos e os tomou pelas mãos quando retomou os estudos, até a entrada na Universidade Federal de São Carlos, onde inicia o caminho que levou ao nosso encontro. 


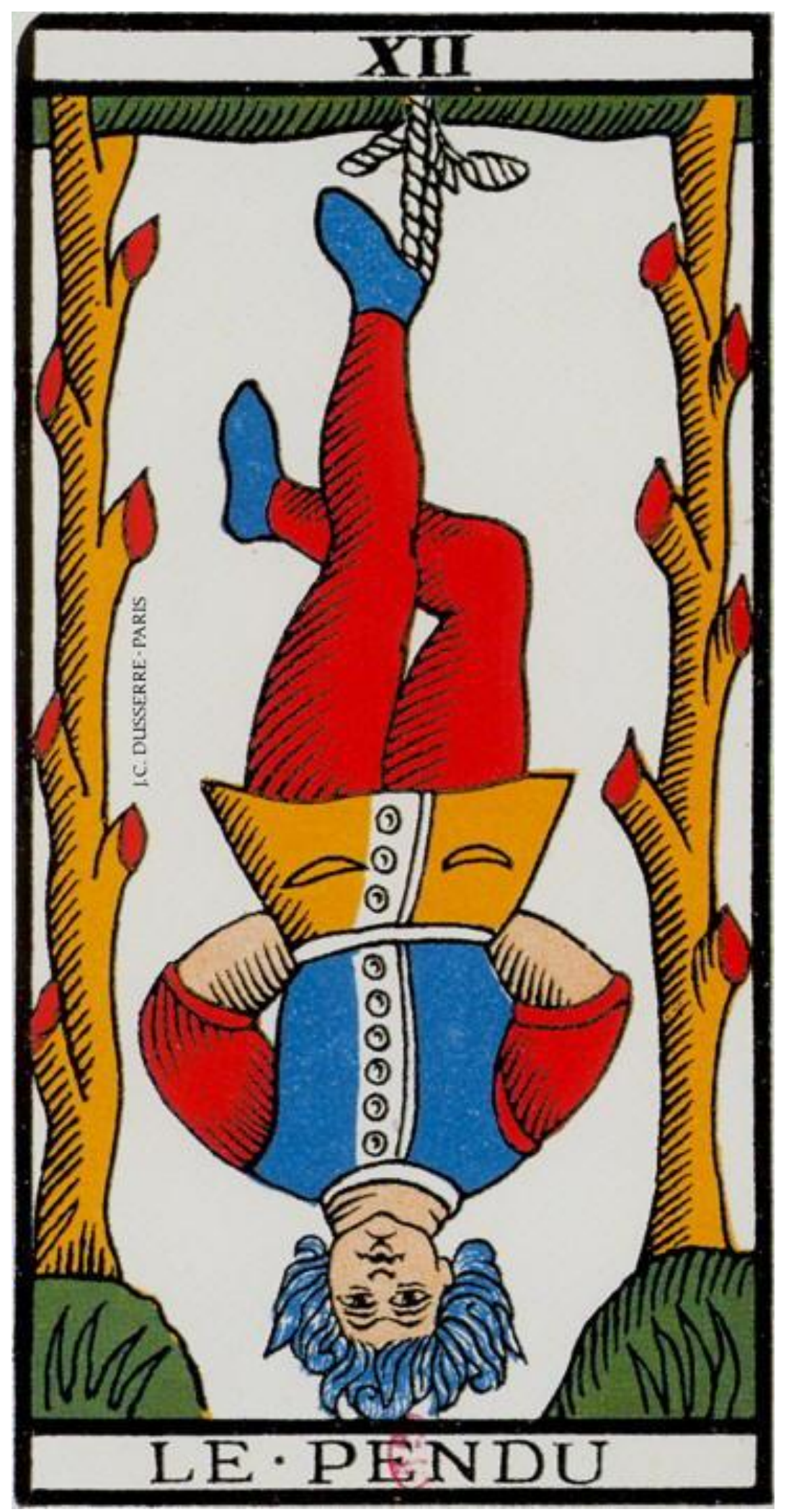




\section{2 - Alice e a BIOMBA}

Malas feitas e era hora de seguir com Castigo para a Escola de Bruxas. Alice estava eufórica para a nova vida. Sabia que seria um tempo de muito aprendizado, de muita dedicação, mas estava feliz pela possibilidade de encontrar outras como ela.

Quem sabe aquela solidão que sentia, aquele buraco no peito, se preenchesse e ela pudesse andar melhor... Se tudo desse certo, Castigo poderia até perder aqueles dentes enormes que havia ganhado e voltar a ser só seu cão de guarda!

Na Escola de Bruxas, Alice conheceu muitas meninasbruxas. Todas elas tinham ar de fada, todas elas tinham poderes mágicos. O fato é que nenhuma sabia usar direito suas magias e não era raro, vê-las feridas ou ferindo outros seres por mau uso de seus dons.

Tinha menina-bruxa de todo lugar, dos reinos mais distantes, das florestas mais afastadas, dos oceanos, das cidades caixa de concreto. Cada uma tinha seu jeito de ser, seu jeito de andar, de voar, de vestir. Todas eram repletas de luz!

Alice se lembrou dos meninos de luz e se sentiu em meio a eles, mas agora de uma forma mais especial. Era como se ela também fosse menina de luz. Ela não ouvia só as histórias que os outros tinham para contar, ela contava as suas e até inventava, quando não tinha nada para dizer.

Havia entre as meninas-bruxas, cinco especiais. As cinco que dividiriam morada num quarto na copa da árvore mais alta do bosque. Era o clã BIOMBA - nome sagrado, dado por uma das mais antigas bruxas que por ali passou. 
Diziam que este quarto-morada fazia das meninasbruxas, grandes bruxas poderosas de grandes magias e feitiços. Alice, sem querer, foi parar no quarto mais cheio de alegria, de amor, de compaixão, de amizade de todo o mundo.

Até Castigo foi bem recebido, até Castigo foi cuidado pelas cinco meninas-bruxas! 


\section{1 - A casa de luz - A descoberta do eu- educadora}

Este conto de Alice se relaciona ao período da graduação, quando cursei Ciências Biológicas na PUC-São Paulo, no campus Sorocaba, SP. Minha primeira residência em Sorocaba foi num pensionato de freiras. Um prédio com aproximadamente 60 meninas de 16 a 20 e poucos anos. Estudantes de ensino médio, graduação, residência médica. Quase todas eram alunas da faculdade de medicina da PUC, mas tinha gente de outros cursos e lugares do país e do exterior.

No primeiro dia de aula, fomos recebidos por alguns veteranos do curso, que nos deram trote como ritual de entrada na faculdade. O trote era diferente do que eu via na televisão. Reunimo-nos em uma turma e fomos até um farol na avenida mais movimentada da cidade. Lá fizemos pedágio para arrecadar dinheiro para a festa no fim de semana. Rostos pintados, muita alegria, novas amizades.

O curso de Biologia era bem vazio. As turmas bem pequenas e evadidas porque a mensalidade era cara, o curso não era reconhecido e ainda muito novo. Pouca gente se aventurava em mudar de cidade e investir tanto dinheiro nestas condições. Tinha muito aluno morador de Sorocaba. Os alunos de fora formavam um pequeno grupo, que se uniu e seguiu junto nas aventuras da vida universitária.

Éramos eu, Joana, Andreia, Gael, Daniel e Nelson. Sempre muito amigos, muito irmãos... Com certa promiscuidade em momentos de descuido, mas muito irmãos. 
Lá fui me encantando com a vida em liberdade, sem mãe, nem padrasto, sem hora (ou quase sem), sem chateação, sem ter que cavar uma luz para ser vista.

$\mathrm{Na}$ festa dos calouros acabei ficando com o Daniel, que se apaixonou por mim e, na aula da manhã do sábado, chegou e me cumprimentou com um beijo na boca. Sentou atrás de mim e pegou na minha mão. Eu tomei um susto, não reagi. Estávamos namorando.

Eu não queria namorar. Tinha acabado de sair de um relacionamento muito abusivo em que não tinha nenhum amor, mas não tive coragem de dizer não. Sentia certa pressão social em ter que namorar e um medo em perder uma oportunidade de estar com alguém e acabar ficando sozinha.

Namoramos três meses e eu terminei a relação. Ele ficou muito triste, mas eu queria aproveitar um pouco da liberdade recém-conquistada. O Daniel insistiu para que reatássemos porem eu recusei. Mas, a verdade é que Daniel ficou ao meu lado durante muitos anos. Acho que foi um dos meus relacionamentos mais longos. Um relacionamento onde nos feríamos, ora ficando com outras pessoas, ora ficando juntos, apenas para nos machucarmos. Foram quase onze anos de presença-ausência, prazer e dor.

No primeiro ano de faculdade, comecei a trabalhar no Parque Zoológico Municipal, onde entrei em contato com a Educação como oficio. Procurei o zoológico com intenção de trabalhar no setor de Biologia, alimentava o sonho de trabalhar com grandes primatas, inspirada no trabalho da pesquisadora Jane Goodall. Mas cursando o primeiro semestre do curso, não era possível e, assim, fui encaminhada para o setor de educação 
ambiental. Eu não sabia o que se fazia neste setor, mas, ingenuamente, aceitei a vaga de estágio porque haveria a possibilidade de estar perto dos animais.

Começamos o ano de 1996 com um grupo de aproximadamente doze estagiários, sendo quatro contratados e oito voluntários como eu. Entre as ações desenvolvidas no Centro de Educação Ambiental, havia a visita guiada, a principal atividade de recebimento dos públicos escolares infantis e juvenis do parque.

$\mathrm{Na}$ minha primeira visita guiada, acompanhei um monitor mais experiente e dei muito sentido para aquela vivência. Poder ensinar sobre animais para crianças em atividade extraescolar. Passei a me empenhar muito para poder assumir um posto de monitoria. Em bem pouco tempo eu era uma das melhores monitoras do zoológico. Adorava todas as atividades desenvolvidas com o público. Havia me encontrado, sem ter me buscado. Foi lá que aprendi a ensinar, aprendi muito sobre zoologia, ecologia, botânica, educação... O zoológico foi meu primeiro emprego. O lugar onde me vi mais feliz profissionalmente... Lá era minha casa, meu bem-estar, meu coração.

A relação com a casa da minha mãe foi ficando cada vez mais distante, até o momento em que eu parei de ir visitá-la com frequência, passando a ir apenas uma vez por semestre.

Em julho daquele ano, participei do meu primeiro curso de férias do zoológico, o Tranzoo - Transando o Zoológico. Em julho, o curso era oferecido para crianças, que passavam cinco dias conosco em atividades variadas. No último dia, dormíamos 
na madrugada ecológica, uma noite destinada ao estudo do meio noturno.

Meu primeiro Tranzoo foi com o tema "Glub-Glub” (água). Eram 80 crianças de 5 a 12 anos, divididas em seis grupos. Cada grupo contava com dois monitores. Foi a melhor experiência pedagógica da minha vida. Grito de guerra, estudo de meio, análises, discussões, gincanas, brincadeiras, músicas, dança, amizade... Éramos 16 estagiários trabalhando juntos. No final de cada dia, juntávamos as crianças no auditório ao ar livre e fazíamos um resumo do dia, contando os pontos da gincana, fazendo a criançada rir com palhaçadas. Brincando, sorrindo, aprendendo junto. A vida podia ser só Tranzoo. Na madrugada ecológica, dormimos na Fazenda Nacional de Ipanema, em Iperó, SP. Ninguém dormiu. Saída noturna, narração de histórias, teatro, brincadeira... Amanhecemos assim, felizes.

Essas foram as primeiras férias que não passei na casa da minha tia. Foi quando cortei o cordão umbilical. Ela entendeu, mas nunca mais foi a mesma coisa. A minha querida tia, que me dava tudo, inclusive atenção, não entendeu a história de eu crescer e ter vontades próprias. Vontades que não incluíam abrir mão da minha vida para estar em sua casa como eu sempre fiz.

Ela não entendia, nem sabia, que, antes, era fuga. Agora, era vida.

No segundo semestre, passei a dividir o quarto com Milene e Andressa, alunas do curso de Medicina. Era um quarto para seis pessoas, dividido entre nós três.

Seis camas, seis armários e três meninas caóticas. Cada uma tinha uma cama para dormir e outra para bagunça. Quando a bagunça começava a invadir a cama de dormir, nos 
apertávamos em uma cama só, até dormir as três, abraçadas uma na outra. Tivemos, nós três, uma relação de amizade das mais íntimas que se pode ter. Sabíamos tudo da vida uma da outra, vivíamos tudo que podíamos viver juntas, dividíamos tudo e não éramos egoístas para nada no que se tratava do trio. A roupa de uma era sempre das três, o shampoo, as toalhas, os absorventes... até o dinheiro. Acho que foi o meu casamento mais feliz.

Em 1997, comecei minha pesquisa de iniciação científica em Educação Ambiental, coordenando as atividades do Clube Ecológico, que estava desativado por falta de educador. Saí do pensionato de freiras e fui morar em república com mais duas amigas. Demos o nome de Biomba para nossa casa. Algum tempo depois, outras três amigas vieram morar conosco. Era uma república feminina só de alunas da Biologia.

Nesse conto de Alice não há novos arquétipos a serem analisados, mas a experiência primeira de Alice de separação voluntária do seu mundo de origem para um local de iniciação. Na jornada do herói (Campbell, 1997), seria representada pela primeira tarefa do herói, que

“(...) consiste em retirar-se da cena mundana dos efeitos secundários e iniciar a jornada pelas regiões causais da psique, onde residem efetivamente as dificuldades, para torná-las claras, erradicá-las em favor de si mesmo (...) e penetrar no domínio da experiência e da assimilação, diretas e sem distorções” (p. 27).

Ao herói é feito um chamado para que passe dos limites estabelecidos, "que separa o herói da sua esfera social, familiar" (Ferreira-Santos e Almeida, 2012). Essa passagem do conhecido para o desconhecido, do limite entre mundos, se deu quando Alice atravessou o bosque em busca da "escola de bruxas". O chamado foi feito pelo Sátiro, a ponte que Alice transpôs e que 
revelou a ela sua verdadeira essência, o que a faria buscar pelo seu lado bruxa. O abandono da imagem da inocência infantil ainda representada pela menina-fada.

A "escola de bruxas" é a representação simbólica do contato de Alice com o "campo de batalhas" onde passará por provas até se "formar" bruxa. É a escola da vida. Onde as experiências imaginárias da infância dão lugar às experiências reais, aquelas que contribuirão para o amadurecimento de Alice.

“As provas são agentes de transformação interior, a ação no mundo exterior implica uma mudança interna; desse modo, a realização heróica corresponde à descoberta de si, à autorrealização. O herói sabe-se em jornada, a existência tornouse uma aventura" (Ferreira-Santos e Almeida, 2012, p. 148)

No conto, as provas não são relatadas. Porém, na autobiografia, já é possível observar os primeiros obstáculos a serem transpostos, os primeiros caminhos iniciados como escolhas da vida adulta, os primeiros erros e os primeiros acertos que terão consequências concretas na jornada do herói.

Considero importante listar alguns, pois são eles que darão direcionamento para as minhas buscas ao longo de boa parte da vida. Em Alice, diz-se que: "O fato é que nenhuma sabia usar direito suas magias e não era raro vê-las feridas ou ferindo outros seres por mau uso de seus dons".

Quando escrevi este trecho, me referia a relação com o masculino. Na autobiografia, cito o namoro com Daniel. No entanto, outros trechos autobiográficos que tratam deste assunto foram suprimidos porque nesta fase fui percebendo uma grande valorização dos relacionamentos românticos em minha escrita. Mas como não sabia de que forma lidar com isso na investigação para a tese, julguei melhor suprimir alguns. Porém, agora, ao 
fazer as análises dos contos, percebo que a sexualidade e as relações com o masculino foram muito importantes para os caminhos que trilhei na busca por quem sou.

Esta observação vai fazendo mais sentido à medida que se desenvolvem as histórias, porém, julgo que esta é uma das provas mais difíceis de Alice: o relacionamento com o masculino. As relações do machucar e machucar-se pelo mau uso dos seus dons. Alice não sabe lidar com sua feminilidade.

$\mathrm{Na}$ autobiografia, há o relato da escolha do caminho profissional. Foi no primeiro ano de faculdade que me encontrei enquanto educadora. Num fazer educativo diferente do convencional, ao ar livre, em conversas, em brincadeiras, em música, poesia e arte... Um fazer educação diferente de tudo que já havia experimentado como aluna. Foi no zoológico, que descobri meu dom. A magia mais desenvolvida de Alice, que no conto é escrito como Alice "contadora de histórias". Desde o início da história de Alice, é sabido de sua experiência e busca por meninos de luz, meninos contadores de histórias. Alice sempre gostou de ouvir, agora em sua iniciação, ela se vê, finalmente, apta para contá-las.

E a terceira prova: a relação com a família. $\mathrm{Na}$ "escola de bruxas", Alice se sente feliz e aceita, está entre aqueles que lhe são comuns. Alice encontrou sua identidade, ela agora é parte. Não há retorno, o que para mim representou a substituição da família pelos amigos, fato marcado até pelo distanciamento da minha tia, único vínculo forte familiar que eu ainda mantinha. Com este fio cortado, me desprenderia das raízes familiares. Esta escolha foi onerosa e foi, também, uma das provas mais difíceis a serem superadas em minha vida. 


\section{2 - O encontro com os mestres - iniciação dos caminhos}

Nesse encontro, Mestre Alcides e Matheus relatam a descoberta de seus dons e as escolhas pelos caminhos que os levariam à maestria. Mestre Alcides, encontrou a capoeira, e Matheus, a Educação Ambiental.

Em seu relato, Mestre Alcid170es nos conta: “Em $69 \mathrm{eu}$ escutei um som de berimbau no aquário. No Crusp tinha uma piscina que os estudantes chamavam de aquário, que hoje é onde fica o Nuri, atrás da arquibancada do Cepeusp. Eu escutei o som de berimbau num sábado (...) eu passei lá perto, olhando, fui convidado para entrar. Era o Mestre Eli e o Mestre Freguesia. Mestre Eli era estudante das sociais, aqui na Universidade de São Paulo e formado do Mestre Suassuna na época. Eu cheguei olhei e não era academia, não tinha uniforme, não tinha instrumento direito, era um pessoal que se reunia com o mestre e os amigos da faculdade para treinar, para brincar. Nem era treino, não tinha aula, não tinha nada, era tocar, ficava brincando, jogando, enfim... fazendo os movimentos e eu fui convidado. Eu não procurei a capoeira, para eu iniciar na capoeira. (...) fui praticamente convidado pela capoeira e foi onde eu me encontrei. Fui convidado, fui aceito, fui escolhido para dar aqui, meu primeiro passo, aprendendo e, enfim, dentro do meio de outra cultura. Eu não sei como explicar isso, mas foi o primeiro passo para eu ter uma iniciação numa outra atividade cultural, que a capoeira eu não conhecia, lá em Minas não tinha, nunca tinha ouvido falar em capoeira. Eu já comecei a sentir que era uma coisa de família, 
me senti pertencente de um grupo. O mestre já levava a gente para tudo lugar, para escola de samba, para o Unidos do Peruche, a gente ia fazer apresentação nas faculdades, fora da universidade. Isso me fortaleceu muito e foi onde eu criei e ganhei uma outra identidade (...) comecei a me sentir importante dentro desse grupo porque nessa época, do regime militar, a gente não tinha liberdade de praticar nada na universidade sem o consentimento dos militares. Como eu trabalhava com esse coronel e todas aulas do mestre eram impedidas pela polícia, eu tive que pedir uma autorização por escrito para o coronel para gente poder praticar capoeira(...) então a polícia abordava a gente e levava para o coronel, o coronel mandava liberar (...) e aí, eu fui gostando e achei que também tinha que estudar"

Assim como eu, Mestre Alcides descobriu-se sem se procurar. A capoeira o "chamou". Os caminhos nos levaram e ouvimos o chamado para a iniciação. Para Mestre Alcides, a entrada na universidade para trabalho de servente foi a passagem do limiar, sendo observada aqui a iniciação, como colocado em suas próprias palavras.

\section{Campbell (1997) explicita:}

"Para aqueles que não recusam o chamado, o primeiro encontro da jornada do herói se dá com uma figura protetora (que, com frequência é uma anciã ou um ancião), que fornece ao aventureiro amuletos que o protejam contra as forças titânicas com que ele está prestes a se deparar" (p.74)

A figura do mestre. Mestre Alcides encontra seu primeiro mestre, aquele que o conduzirá em sua jornada, mostrando os caminhos, orientando as ações. 
A iniciação do Mestre Alcides se dá no diálogo com sua ancestralidade e, assim como eu, quando há este encontro pelo caminho que se quer seguir, ele se sente parte. Mestre Alcides tem agora sua identidade dentro de um grupo de comuns. Não está mais só em sua jornada.

Matheus também nos conta de sua iniciação: "Eu era professor de Ciências. Eu terminei o curso de licenciatura e já fiz a complementação em Ciências Biológicas, só que lá em Machado, em Minas, porque aqui na federal não tinha montado o curso de Biologia. Eu tive que dar aula para sobreviver e, para gente pegar aula, tinha que fazer o curso de licenciatura plena. Eu tive que fazer lá em Machado que era mais fácil para mim, porque era um curso de final de semana, eu ia de sextafeira e voltava no sábado. Tinha uma turminha que ia comigo, a gente se reunia, rachava o carro, a perua Veraneio. Aí eu peguei umas aulas, fui dando aula e surgiu a oportunidade aqui na USP, como técnico de laboratório. Na verdade, não era nem técnico de laboratório, era uma bolsa para trabalhar num projeto da OEA (Organização dos Estados Americanos), que era com o professor Samuel Branco. Ele vinha para cá (CHREA) e precisava de um biólogo para ajudar (...) Nessa época devia ter uns vinte e três, vinte e quatro anos. Eu dava aula no Sesi, aqui em São Carlos, então estava em Ribeirão Bonito, Taubaté, Eldorado e surgiu esta oportunidade de vir trabalhar aqui com o Tundise e com o Samuel Branco. O Samuel precisava de um biólogo e o Tundise me indicou. Era trabalho integral, dezoito meses de bolsa. Ganhava muito bem. Eu trabalhei dezoito meses, aí, estava acabando a bolsa, ele falou para mim: 'Matheus, olha, a bolsa está acabando e não tem como renovar, 
mas tem uma chance de você entrar aqui, ficar com a gente. Tem um funcionário que está saindo e daqui alguns meses vai abrir uma vaga aqui de técnico de laboratório'. O salário era metade do que eu ganhava. Não tinha nada fixo, as aulas que eu dava eram à noite, não atrapalhava em nada. Aí foram surgindo outras oportunidades e eu fiquei até hoje. As coisas foram melhorando, mas foi assim que aconteceram as coisas, eu não tinha nada assim 'Vou fazer isso porque tem lá. As coisas foram acontecendo e parece que os caminhos foram dando certo, porque o que eu faço hoje é a coisa que eu amo fazer... eu amo fazer... era aquilo que eu queria fazer e que não sabia o que era, na verdade, o que eu quero é isso mesmo. O que eu gosto de fazer é isso, é mexer com pessoas, formar pessoas, é passar coisas boas, trazer coisas boas para as pessoas... É isso que eu quero fazer."

Matheus também teve um encontro com um mestre. $\mathrm{O}$ trabalho com os professores-pesquisadores José Galísia Tundise e Samuel Murgel Branco abriu para Matheus as portas do ambiente acadêmico, que mais tarde se revelariam como sua arte-ofício no trabalho com Educação Ambiental. Aqui, Matheus apenas adentra o espaço de iniciação, assim como Alice. Porque sua realização pessoal, seu dom, não estão na pesquisa de laboratório ou escrita de artigos. Esta descoberta pela área da Educação se dará no próximo passo. Porém, o caminho iniciático foi descoberto. E assim, como Mestre Alcides e eu, o encontro foi espontâneo, um chamado, uma descoberta. 


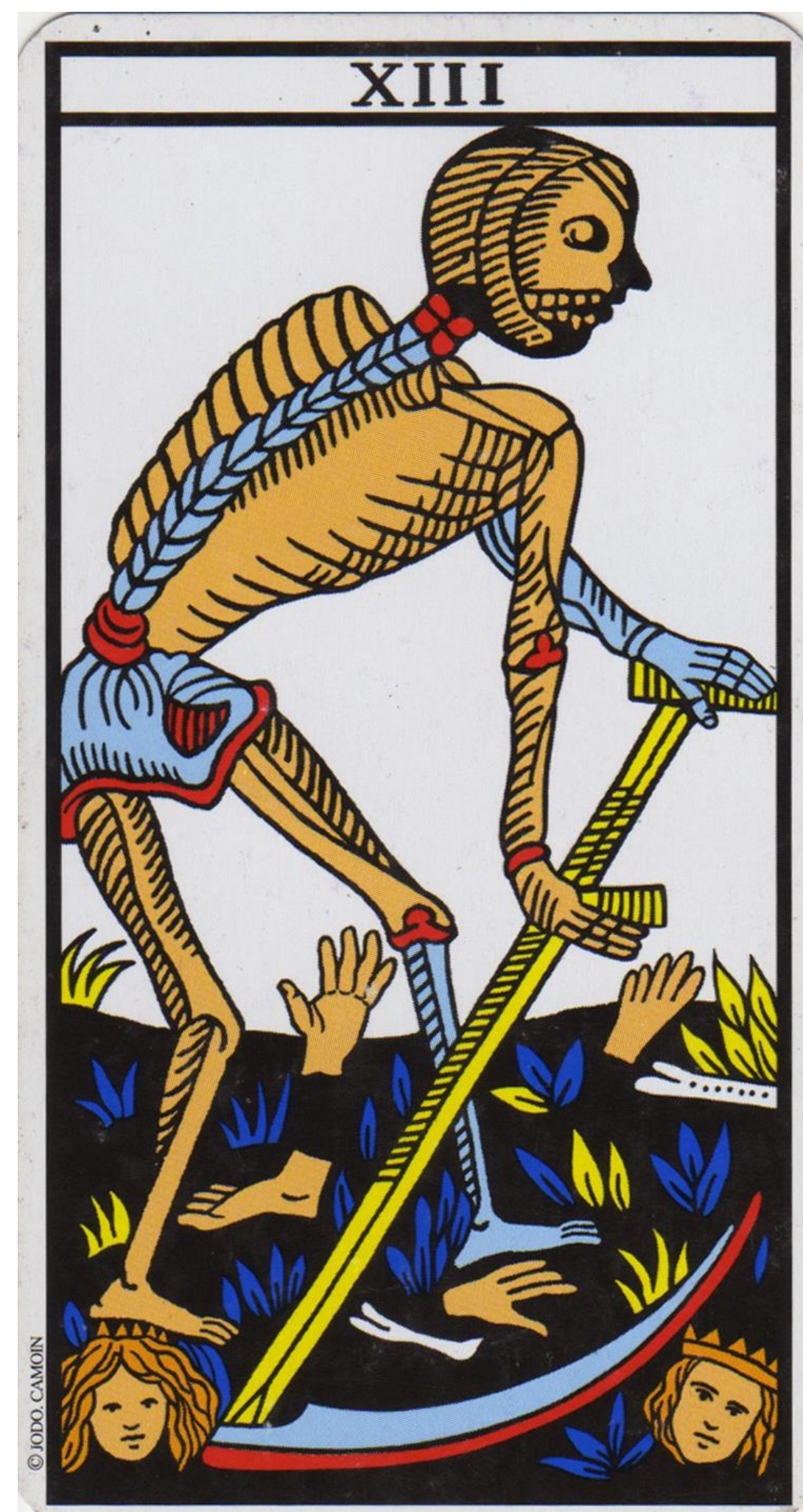




\section{3 - Alice e as festas das luzes}

Alice estava muito feliz com a vida na Escola de Bruxas. Alice aprendia muito. Alice sorria. Alice chorava. Alice sonhava, fazia planos, fantasiava novos caminhos para seguir.

As meninas-bruxas iam crescendo e se tornando mulheres-bruxas. Cada dia que passava, cada ano juntas serviam como aprendizado. A vida que dividiam as ajudavam a entender melhor seus dons e suas magias.

A vida ali começou a ficar pequena e logo as meninasbruxas estavam procurando por novas histórias, tentando conhecer outras pessoas, explorando a vida para poder seguir sozinhas depois.

Foi numa dessas andanças que certa noite Alice partiu só pelo bosque. Alice caminhava e cantava... Alice pensava em todas as aventuras que já havia vivido. Alice sonhava!

Alice andou tanto que não se deu conta que havia se afastado do seu quarto-morada. Foi num suspiro que ela ouviu uma canção. Foi chegando perto, observando de longe e avistou um bando de insetos gigantes cantadores.

Eram muito animados, tocavam instrumentos, bebiam $e$ riam alto de coisas que Alice não podia entender. Alice foi se aproximando e percebeu que entre eles estavam algumas das meninas-bruxas. Alice se sentiu em casa!

Entrou na festa e bailou até o Sol nascer. Era dia e ninguém queria ir embora! A ideia então foi levar toda aquela festa para a Biomba. Elas deveriam fazer isto escondido, porque a regra é que ninguém além delas poderia conhecer aquele lugar mágico. 
Os insetos se apertaram, se dobraram, se esmagaram tentando se encaixar nas cestas de frutas que estavam jogadas no chão. Ao chegar no quarto-morada, esticaram os corpos, se espreguiçaram, pegaram os instrumentos e fizeram, daquele lugar, o lugar mais cheio de música e de vida que já havia existido na Escola de Bruxas. Logo, todos iam para lá... Logo, lá era o lugar dos encontros...

O tempo passou e a festa acabou. Chegou o dia da despedida e as meninas-mulheres-bruxas se abraçaram. Alegria e dor se misturavam. Estava na hora de cada uma descobrir seu caminho.

Alice chorou muito e junto dela, ficou apenas seu fiel escudeiro Castigo. 


\section{1 - Até as luzes se apagarem... - sobre a vida na faculdade, o fim e as novas buscas}

Este conto de Alice se refere ao período entre o segundo e o quarto ano de faculdade. Período em que morei na república e cresci profissionalmente, já investindo fortemente na carreira como educadora ambiental. Nesta fase, também vivi um grande amor e posteriormente, o encontro com o pai do meu primeiro filho.

Em 1997, entre os calouros recém-chegados na faculdade, estava um estudante paulista, amigo de uma das meninas da república. Seu nome era Cristiano e, um dia, num sorriso largo ele me conquistou. Fiquei completamente apaixonada, como nunca antes na vida. O início do relacionamento foi conturbado e depois de cinco meses ficando juntos, começamos a namorar.

O relacionamento durou dois anos. Durante esse tempo, conheci sua família e vivi, pela primeira vez, um cotidiano familiar mais próximo do modelo por mim idealizado. Um pai e uma mãe intelectuais, professores de universidade, que se amavam, se apoiavam, se respeitavam e acolhiam os filhos. Irmãos que se davam bem e uma harmonia que eu não sabia que podia ser possível em uma família. Eles me receberam como uma filha e eu os amei a ponto de nunca os esquecer.

Esse relacionamento me abriu portas para um novo mundo - o da classe média intelectual paulistana. Eles moravam no bairro de Pinheiros e depois se mudaram para a Granja Vianna, também em São Paulo. Eu, que vinha da Praia Grande, fui apresentada a uma realidade extremamente sedutora. Eram pessoas cultas, com conversas "cheias de conteúdo", um jeito 
diferente de se vestir e de pensar sobre o mundo; um jeito que eu pensei ser do meu tamanho. Havia me encontrado entre os adultos. E melhor, eles me aceitaram e me amaram no meu jeito se ser.

Porém, havia entre mim e o Cristiano algumas diferenças na forma de estar no mundo, nos hábitos, no jeito de levar a vida. Ele havia recebido uma educação mais libertária e mais liberal, não tinha tantos tabus como eu e sua relação com o certo e errado era bem mais maleável que a minha. Durante algum tempo, nos adaptamos e vivemos o que pudemos de melhor, porém em 1999, ele se mudou para uma república mista, o que gerou muito ciúme em mim.

A república se chamava Bola Um e os moradores se chamavam os "bioloucos". O Cristiano, que havia se adaptado bastante à minha forma de viver, numa relação mais comprometida com o trabalho e estudo, encontrou em sua nova casa, parceiros com hábitos mais próximos aos seus. Era um grupo que estava de forma mais leve e mais descomprometida com a vida.

Ele foi se afastando do nosso mundo e do nosso relacionamento, vivendo de forma mais displicente e eu, sempre muito centrada e controladora, não consegui me adaptar. Sentiame sozinha na relação, ele estava mais comprometido com seu bando. Em pouco tempo terminamos a relação.

Em um primeiro momento, foi muito sofrido para ele. Eu me sentia livre para poder voar sozinha e só depois, muito tempo depois, senti a dor desse afastamento.

Enquanto vivia essa linda história de amor, me dediquei ao trabalho e aos estudos. Continuei trabalhando no zoológico 
com educação ambiental, desenvolvia projetos, escrevia artigos e apresentava trabalhos em congressos. Cresceu em mim o sonho de me tornar uma referência na área. Já nessa época, tinha como objetivo seguir carreira acadêmica e, para tanto, me empenhava em "colecionar" certificados.

Depois do zoológico, trabalhei como educadora ambiental em diversos parques da cidade e, posteriormente, fui contratada no Parque Ecológico do Colégio Objetivo, em Itapetininga, SP. Durante toda a faculdade tive salário ganho com o ofício que me dava prazer e no qual me dedicaria por muitos anos da minha vida.

No último ano da faculdade, alguns meses depois de me separar do Cristiano, conheci o pai do meu primeiro filho. Minha república havia se tornado um ponto de encontro da classe artística da cidade. A Gael namorava um músico jazzista que trouxe para nossa casa músicos talentosos, estudantes do Conservatório de Tatuí. Junto com os músicos vieram os atores, diretores de teatro, compositores, escritores. Quase todo dia, a noite era sarau na nossa casa.

Entre os músicos, estava um muito conhecido na cidade, João Leopoldo. Pianista, compositor, ator... Começamos a namorar em setembro e com ele permaneci até 2005.

No fim de 1999, nos formamos. Foi um dos momentos mais difíceis da minha vida. A casa que era meu lar, as meninas que eram minha família, a vida que dividíamos estava para terminar. As meninas seguiriam seus caminhos. Algumas voltaram para casa, outras alçaram voos mais distantes, partindo para experiências internacionais. Eu não tinha para onde voltar e nem para onde partir. Acabei ficando sozinha na casa. Junto da 
minha solidão, a tristeza e a saudade da vida compartilhada com gente tão especial.

Nesse conto de Alice, podemos partir de algumas representações simbólicas que se referem a trechos específicos da autobiografia - a transformação das meninas em mulheres, as experiências vividas em comunhão, a curiosidade que leva a novas buscas, o encontro com a arte, a música e o corpo que dança na melodia de uma vida que se constrói, a separação e o fim de um ciclo.

\section{2 - A entrada no labirinto - os itinerários de formação}

Neste conto de Alice, Alice se vê contaminada por um sentimento de curiosidade, de buscas pelo novo, pelo desconhecido. Apesar de muito feliz entre as meninas-bruxas, Alice sente seu amadurecimento pela vontade de expandir seu mundo e, assim, sai em busca de novos caminhos.

Estes caminhos à levam ao encontro de "insetos gigantes cantadores", uma representação simbólica de uma efervescência interior, da busca de um algo mais, da compreensão sobre um estar no mundo, sobre um "iluminar" o viver, um simbólico classificado em Durand (2012) como pertencente ao regime diurno do ser.

Para Durand, alguns símbolos representam as "faces do tempo", a relação do ser com a durabilidade, a vida-morte, pois se trata de simbolizar a percepção da finitude do tempo e de seu escorrer ininterrupto. Destes símbolos, temos os que se relacionam aos animais com uma relação direta entre animado e 
inanimado, à maneira como os processos dinâmicos se apresentam à imaginação, "o animal não é mais que o resíduo morto e estereotipado da atenção ao movimento vital” (2012, p. 73).

Esse conto de Alice traz por meio das imagens uma angústia sobre este tempo vivido. O fim da vida em república, o início e o fim de uma grande história de amor, a tomada de decisão sobre o futuro. Foi um momento de significativas mudanças, que precisei me reorganizar quanto aos sonhos e iniciar a empreitada de construção da vida adulta. Foi o momento de passagem da vida de estudante para a profissional, os sonhos românticos foram desfeitos e os laços de amizade que alicerçavam um estar no mundo estariam mais frouxos, mais distantes. Um caos interno se instalava, gerando uma grande ansiedade sobre como seria o futuro.

Os "insetos gigantes cantadores" podem simbolizar uma manifestação de imagem primitiva que Durand chama de "formigamento" - no sentido de "agitação", do "fervilhar". Um movimento que

“(...) revela a animalidade à imaginação e dá uma aura pejorativa à multiplicidade que se agita (...) Para consciência comum, todo inseto e todo verme é larva (...) Essa repugnância primitiva diante da agitação racionaliza-se na variante do esquema da animação que o arquétipo do caos constitui (...) O esquema da animação acelerada que é a agitação formigante, fervilhante ou caótica parece ser uma projeção assimiladora da angústia diante da mudança, e a adaptação animal não faz mais, com a fuga, que compensar uma mudança brusca por outra mudança brusca" (2012, p. 74)

Ao construir a imagem de festa na morada Alice, de um borbulhar de sons e de corpos dançantes, acabei por representar a angústia das mudanças pelas quais passaria nessa fase de 
transição, "o medo diante da fuga do tempo simbolizada pela mudança e pelo ruído". Tais quais os insetos de Alice, que foram espremidos e amassados para serem incorporados em sua morada, em sua existência. O que parecia uma grande festa era só representação de um caos interno e do medo das mudanças que antevia.

Neste trecho da autobiografia, também é dado que busco por outros processos de formação que estão além da universidade, além da academia. Minha busca está além do fazer-me peça de encaixe de uma sociedade previamente organizada para determinados fins. Busco algo que dialogue com o conhecimento, mas que acima de tudo acrescente em mim enquanto aprendiz. Minha sede pelo saber, por respostas, por novas formas de ensinar, por produzir, por ser mais, me levam a outros itinerários:

“Assim, não me educo para o futuro, para o vestibular, para o
mercado de trabalho, para o dia que for adulto ou velho. Educo-
me por prazer, educo-me para responder às minhas questões,
sejam cotidianas, existenciais, práticas, filosóficas, sexuais,
sentimentais ou de qualquer outra ordem (...) os itinerários de
formação valorizam a complexidade, os processos simbólicos que
perfazem a cultura, a razão sensível, a construção de si, a obra de
arte e a arte-educação, a dimensão ética e estética da vida, a
pluralidade e a prática de uma pedagogia da escolha e todas as
atividades fundamentais para a formação da pessoa” (Ferreira-
Santos e Almeida, 2012, p. 143)

Este estar no mundo de forma aprendiz, me leva à escolha de caminhos que me propiciarão encontrar em mim, mais do que um saber pragmático, hermético e racional. Buscarei por caminhos que me tragam a experiência do conhecimento como algo mais humano e transcendente. Aqui começa a trajetória de encontro com mestres. O primeiro mestre deverá trazer luz a esta 
nova forma de me relacionar com o conhecimento. Parto em busca do meu mestre diurno.

\section{3 - O encontro com os mestres - os primeiros passos para o caminho da maestria}

Aqui, os encontros com os mestres vão se esbarrando nas buscas, na tessitura do ser diurno, na constituição e na experiência com a busca e a construção do saber mais técnico, mais científico e acadêmico. Mestre Alcides e Matheus, com origens tão diferentes e distantes acabam por viver experiências muito semelhantes dentro do espaço acadêmico.

Mestre Alcides em seu relato nos conta: "Achei que também tinha que estudar, entrei no ginásio naquela época, eu só tinha o quarto ano primário, fiz o ginásio, fiz até a oitava série e fui para o colegial. Fiz o colegial, entrei na faculdade de Educação Física nos anos 8o, sempre trabalhando no Coseas, quando foi nos anos 80 eu pedi transferência, eu fui convidado, para trabalhar na área de Oceanografia Química no Instituto Oceanográfico. Mudei radicalmente de atividade profissional na USP, eu fui ser técnico especializado de apoio de ensino e pesquisa na área de Oceanografia Química. O técnico tem que entender toda a metodologia da pesquisa que o docente está dando à disciplina teórica para os alunos, na época, só pósgraduação, então, era um estudo de alto nível mesmo, porque eu tinha que pegar esse aluno que estava fazendo mestrado $e$ doutorado, levar para o laboratório de química e ensiná-lo tudo na prática o que ele aprendeu só na teoria com o docente no semestre, ou seja, fazer hidrocarboneto, estudo sobre graxas ou 
contaminação por petróleo. Eu tinha que pegar a metodologia, estudar e fazer todo esses experimentos com ele no laboratório, ou então... 'Ah, mas tem oxigênio dissolvido, tem toda a parte de nitrogenados', então levava para o laboratório, ensinava como se organiza uma viagem, eu levava para o mar, para a base Norte-Ubatuba ou Sul-Cananéia... Montar laboratório no barco, eu tinha que ensinar tudo isso, foi uma mudança muito grande para quem entrou na universidade fazendo faxina $e$ chegar um momento estar trabalhando na área de pesquisa. Fui do Programa Antártico-Brasileiro. Quatro, cinco vezes fui para Antártica, uma ou duas das vezes fui coordenando o projeto de pesquisa também. Mas antes de tudo isso, no Coseas, eu trabalhei em várias áreas da administração, trabalhei em tesouraria, trabalhei em setor pessoal, trabalhei na parte de compras, enfim, trabalhei em várias áreas. Isso é porque, como eu disse no começo, eu sempre fui muito focado".

Mestre Alcides foi ao mar. Mestre Alcides foi navegar em águas muito distantes e geladas. Foi conduzindo o barco em processos do ensinar e aprender. Desenvolveu habilidades técnicas e analíticas. Viajou o mundo... E este relato se encontra com o de Matheus, que foi virar rio, como relatado por ele: " $E u$ trabalhava como biólogo e, apoiando o curso de mestrado, fui assistente de aula prática do Samuel Branco. Daí o Tundise chegou e eu comecei a trabalhar com o Tundise numa parte muito técnica, era limnologia, aquela coisa de coleta de água, trabalho em publicação de artigo sobre como funciona o ecossistema aquático, essas coisas. Eu gostava daquilo, mas não era uma coisa que me trazia um prazer, era gostoso mas ao mesmo tempo eu não via muito sentido para minha vida. Não 
era isso que eu queria da vida. É importante para aprender, saber sobre natureza, meio ambiente e tal, mas faltava alguma coisa. Nessa trajetória o Tundise e o CDCC fizeram uma parceria e criaram um curso aqui de extensão para professores. Eram professores da rede estadual que vinham aqui, passar uma semana... e era montado assim o curso, vinha um grupo de, vamos supor, trinta professores, nas férias... sempre em janeiro, julho, né... Então o CDCC dava todo o suporte de ônibus para trazer os professores para cá (...) Isso foi em 1986. Eles vinham para cá, ficavam aqui a semana inteira, integral, então dividia em grupos, um grupo ia para represa e estudava a represa, tinha todo o equipamento, barco, fazia as coletas de água, profundidade, esse aí é um exemplo. Ai, outro grupo ia para o cerrado, media a umidade do cerrado, outro aparelho media a temperatura do cerrado, da mata, do solo e tal. Tinha uma experiência de você conhecer a biodiversidade do cerrado, você coletava os insetos ali e outro grupo ia para mata homogênea de pinus e outro na mata de galeria, mata ciliar e os rios, decidia tudo em grupos e cada um levantava o máximo de informação de cada ecossistema, reunia depois aqui na sala de aula e apresentava os seus resultados e todo mundo trocava experiência. Era isso o curso. E esse tipo de atividade, me chamou atenção... Falei: 'Pô, esse negócio é bacana!... Eu estou sentindo mais prazer em fazer isso do que ficar só simplesmente coletando água e analisando água' (...) Eu falei: 'O contato humano para mim é mais interessante, , eu achei, é isso que eu quero fazer' (...) O Tundise foi passando e saiu. Antes de sair, a Gabriela que estava aqui e que também participava destes cursos, era bolsista de pós-doc, montou um curso de 
aperfeiçoamento de Educação Ambiental. Só que não era Educação Ambiental, a palavra era educação ambiental, mas o curso em si não era, assim como o curso do Tundise não era educação ambiental (...) Chamava Educação Ambiental, tinha educação ambiental, a bacia hidrográfica, comunidades de estudo, coisas assim. Ela montou um curso de cento e oitenta horas. Fez parte inclusive do pós-doc dela e eu acompanhei esse curso junto com ela, ajudei a montar tudo, durou três anos esse curso e ela saiu também. Aí, eu falei :'Não! Esse curso tem que continuar... pô, um negócio super bacana', gostei da ideia”.

Um encontro que acontece na investigação desta tese e se compõem em poesia: o encontro da água doce com a água salgada, o rio que deságua no mar. A doçura de Matheus com suas águas mansas e a força de Mestre Alcides que, como as ondas do mar, me levaram ao oceano. Neste encontro de águas, eu fui mangue - ambiente de fertilidade do imaginário. Bachelard (1998), ao nos falar sobre as águas compostas, bem ilustra este encontro:

"Em especial, a água é o elemento mais favorável para ilustrar os temas da combinação dos poderes. Ela assimila tantas substâncias! Traz para si tantas essências! Recebe com igual facilidade as matérias contrárias, o açúcar e o sal. Impregna-se de todas as cores, de todos os sabores, de todos os cheiros. Compreende-se, pois, que o fenômeno da dissolução dos sólidos na água seja um dos principais fenômenos dessa química ingênua que continua a ser a química do senso comum e que, com um pouco de sonho, é a química dos poetas” (p.97). 


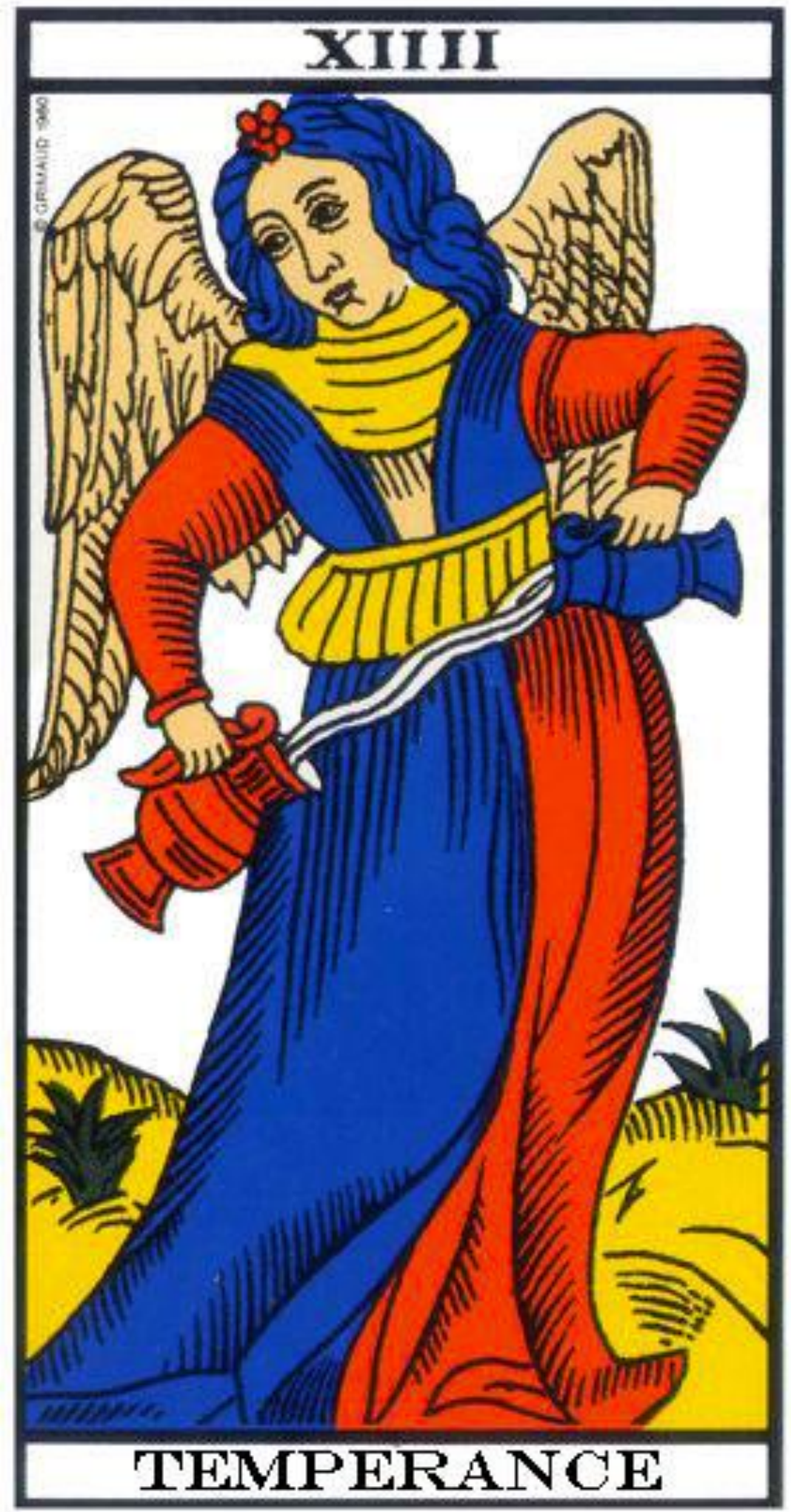




\section{4 - O presente de Alice}

Alice precisava seguir seu caminho. Pegou todos os seus pertences, enfiou numa mala, banhou Castigo, o deixou bonito, limpo e cheiroso, e seguiu viagem. Era a viagem mais dificil de Alice. Alice, diferente das outras meninas-mulheres-bruxas, não tinha para onde voltar. Andava e tentava pensar em alguma solução. O que fazer? Para onde ir?

Alice teria que recomeçar, mas não sabia exatamente o que deveria recomeçar. Voltar para a caverna onde morava o dragão? Não! Definitivamente, Alice sabia que esta não seria uma boa saída. Alice ia bem sem aquela sombra horrorosa que a aterrorizava.

Alice caminhou, caminhou, caminhou e viu um homem velho, um velho homem branco sábio. Ele estava sentado em uma pedra, segurando um cajado e contando histórias para algumas crianças que o ouviam com muita atenção.

O velho branco sábio gesticulava e suas mãos quase falavam por ele. Iam e voltavam, junto com um corpo que às vezes se levantava para dar vida ao que falava. Alice se interessou. Sentou com Castigo e ficou prestando atenção na cena.

O velho branco sábio avistou Alice, com um sorriso manso no rosto, fez um gesto com a mão e a chamou para perto. Ninguém falou nada. Todos olharam para Alice e a receberam como se soubessem quem ela era.

Alice sentou-se, ouviu muitas histórias e ficou encantada com aquele velho branco sábio. No final da tarde, quando todos se levantavam para ir embora, o velho a convidou para seguir 
com ele. Ao chegar em sua casa, o velho a acomodou em um quarto limpo e organizado. Era um quarto acolhedor e quente. Alice ficou na cama e Castigo, no tapete ao lado.

Era um velho gentil, lhe ofereceu um prato de sopa quente e uma vela para que Alice não ficasse no escuro.

No dia seguinte, quando Alice abriu os olhos, viu uma cesta no chão. A cesta se mexia e fazia barulhos engraçados... Alice curiosa que era, levantou com cuidado o pano que cobria a cesta. Havia um bebê! Um lindo bebê.

Alice não sabia o que fazer, não sabia se acolhia, não sabia se empurrava, não sabia se deixava lá... Mas aqueles olhos cheios de amor encantaram Alice e a enfeitiçaram.

O velho branco sábio entrou no quarto, disse a ela que aquele era um presente que havia sido deixado ali há muito tempo e estava endereçado a ela. O velho sabia que Alice chegaria e por isso a acolheu com tanto carinho quando ela chegou.

Alice estava pronta para seguir... A partir de agora, seria Alice, o Presente e Castigo, seu fiel cão escudeiro. 


\section{1 - Vida-morte-vida - sobre os renascimentos}

Este conto de Alice se refere ao encerramento do ciclo Biomba, da busca por novos caminhos profissionais e acadêmicos, do encontro com Matheus, do nascimento do meu primeiro filho, João Pedro.

No dia da despedida da nossa república, fiquei completamente perdida. Não sabia para onde caminhar. Algumas das meninas seguiram para empreitadas no exterior, algumas voltaram para casa dos pais. Eu fiquei sem saída. Fiquei sem chão. Fiquei na solidão por ter perdido aquela que era minha família.

Acabei ficando sozinha na casa onde morávamos. Estava namorando o João Leopoldo e ele acabou indo morar comigo. Mesmo assim, me sentia muito sozinha. Comecei a dar aulas na rede pública e iniciar a vida fora do espaço acadêmico.

No final do ano 2000, participei do processo seletivo para mestrado no CRHEA/USP, de São Carlos, SP. Era minha segunda tentativa, já havia tentado no ano anterior e havia reprovado. Não foi diferente desta vez. Porém um amigo da faculdade que já cursava pós-graduação nesse local, me indicou para o coordenador do curso de especialização em Educação Ambiental e recebi um convite para participar do processo seletivo.

Em janeiro de 2001, comecei o curso. O coordenador do curso era o Matheus e aqui se deu o encontro com meu primeiro mestre de vida. O curso era voltado para professores da rede pública e organizado em três módulos. As aulas aconteciam 
sempre nas férias escolares com o intuito de possibilitar que os alunos se deslocassem de seu local de origem, sem ter que abandonar seus empregos.

Havia gente de vários Estados do país e diversas formações. O curso tinha um caráter bastante peculiar. Apesar de o primeiro módulo ser bastante científico, Matheus nos recebia e acolhia de forma tão especial, que o grupo criou vínculos muito fortes. Nós chamávamos de família. O primeiro módulo foi tão intenso e especial, que tomei a decisão de mudar para São Carlos, me dedicar aos estudos e prestar o mestrado mais uma vez, agora sob orientação de Matheus.

Eu não tinha emprego, vivia com uma pequena quantia de dinheiro que meu pai me enviava mensalmente. Cursei algumas disciplinas como aluna especial. No tempo livre, frequentava a Oficina Cultural e lá fiz muitos cursos de arte, direção teatral, dança, circo e montei com alguns amigos, um grupo de teatro GRUTATEVIPOTA- Grupo Tartufo de Teatro Vica-Pota.

Participamos de festivais e me dediquei à arte nessa fase da vida. Decidi que trabalharia com arte-educação ambiental e buscava desenvolver meu lado artista nas oficinas, aulas e palestras que tinha oportunidade de ministrar. Também me envolvi com o movimento ambientalista, trabalhei voluntariamente um uma ONG, me tornei vegetariana e budista. Foi um tempo de muitas descobertas.

Lá, também conquistei novas amizades, entre elas, Mírian, Cibele e Hellen. Mulheres fortes, que se mantiveram ao meu lado durante muitos anos. Mírian tinha um filho pequeno, morava em república com seu marido e a criança e eu tive o imenso prazer de conviver com a maternidade mais próxima de mim. Sempre 
quis ser mãe e poder partilhar daquele espaço familiar era muito prazeroso.

Em setembro de 2001, em uma das idas e vindas no meu relacionamento à distância com João Leopoldo, engravidei. Foi uma surpresa. Não foi planejado. Foi um presente. Descobri a gravidez no mês de dezembro, em férias na casa de seus pais. João ficou bastante surpreso. Ele que já tinha uma filha de um relacionamento anterior e não tinha intenção de ter mais filhos. Foi uma fase muito difícil para mim. Senti uma profunda solidão. Não tinha família para dar apoio e ele, que era meu companheiro, também não conseguiu fazer este papel.

Sua mãe se colocou à frente da situação e me acolheu. Ela era a única pessoa com quem eu podia contar como um apoio afetivo e familiar. Estava sozinha em São Carlos, desempregada e sem perspectivas sobre como lidar com a situação.

Em fevereiro, fui contemplada com uma bolsa de aperfeiçoamento técnico da Fapesp para trabalhar em um projeto de educação ambiental na represa do Broa, sob coordenação do Matheus. Esta fresta de luz que entrou pela janela, invadiu outros cômodos da minha vida, então escura, e trouxe Matheus para mais perto de mim.

Matheus, quando soube da gravidez ficou surpreso com a situação de abandono em que eu me encontrava. Ele não conseguia entender como uma "menina" grávida podia estar tão só, sem apoio de ninguém além dos amigos que eu acabara de fazer naquela nova cidade. Ele, então, num gesto de solidariedade, me acolheu como uma filha.

Fiz todo o pré-natal em São Carlos e nunca fui acompanhada em nenhuma consulta. Via o pai do meu filho 
apenas uma vez por mês, nos finais de semana em que eu me deslocava entre cidades para o encontro. Poucas foram as vezes em que ele foi me visitar.

Porém, eu estava tão feliz pela possibilidade de realizar meu sonho de ser mãe, que não percebia o quanto estava desamparada. Ninguém da minha família me viu grávida. Só Matheus acompanhou de perto este momento da minha vida.

Paralelo ao me gestar mãe, desenvolvi o projeto de pesquisa no CRHEA. Trabalhamos com a comunidade moradora do entorno da represa do Broa e na formação de professores da cidade de Itirapina. Foram seis meses de trabalho de campo. Um tempo de muito aprendizado, muito trabalho, muita conquista.

\section{2 - A busca por novos caminhos - o ambientalismo}

Neste conto de Alice, ela aparece recomeçando em uma busca por novos caminhos. Caminhos estes que a levaram ao encontro de seu primeiro mestre, o velho homem branco sábio. Aqui, o encontro com Matheus.

Matheus foi meu orientador na especialização, foi o mestre que me iniciou, de fato, na carreira como pesquisadora numa área específica. No curso de especialização em Educação Ambiental, tive contato com professores e conteúdos, pessoas e histórias que me levaram a descobrir a Educação Ambiental como uma ideologia para além de uma área de estudos. Nossas discussões, práticas e leituras me mostraram que havia algo mais do que um discurso sobre a proteção de "plantas e bichinhos". 
Desenvolvi um olhar mais humano, com buscas sobre a constituição do sujeito enquanto parte de um todo. Educação Ambiental deixou de ser disciplina, passou a ser um modo de vida.

Toda teoria que envolvia meus trabalhos e que nunca foram incorporados à vida passaram a ser diretrizes para um estar no mundo mais consciente, mais político, mais participativo. Eu deixei de ser a professora que ensina, para ser alguém que pudesse aprender com meu próprio ensinar.

Todas estas mudanças na forma de me relacionar com o que antes era só trabalho, me levaram a buscar uma nova compreensão sobre o significado de estar no mundo, de estar na vida. Mudei hábitos com relação à geração de resíduos, passei a me preocupar com alimentação, busquei desenvolver minha espiritualidade. A arte passou a ser língua falada. Deixei de ser público e fui pintar minha própria história.

Uma opção por uma vida mais simples, mais desprovida de bens materiais, com mais horas de descanso, com a descoberta do ócio como espaço criativo. Incorporei ideias sobre um mundo melhor a partir da constituição de um eu maior. A busca por uma vida com mais sentido, com mais plenitude, com mais responsabilidade sobre mim e o outro.

Matheus sempre falou do céu, da terra, do homem, do verde, das buscas... Matheus nos ensinou a contemplar, a buscar, imaginar, desenvolver paciência com os processos para a compreensão dos ciclos.

Matheus nos contos de Alice era o velho homem branco sábio. Foi ele quem me levou aos caminhos da descoberta e do desenvolvimento da Ciência, enquanto espaço filosófico e 
reflexivo, epistemológico, teórico e imaginativo. Matheus foi meu mestre diurno, segundo definições bachelardianas.

Bachelard apresenta em sua obra, dois momentos assim reconhecidos: diurno e noturno. Em sua fase classificada diurna, Bachelard trata sobre a Ciência - epistemologia, história e o próprio fazer científico. Em sua obra "Formação do Espírito Científico" (1996), o autor discorre sobre os estágios para a constituição do espírito científico: realismo, empirismo e racionalismo; estágios estes que estariam presentes desde a filosofia, a contemplação, a busca por respostas, as experimentações e os processos imaginativos envolvidos para tal até a abstração; um "colocar luz", "iluminar o inconsciente" e racionalizar as imagens produzidas no processo do fazer científico (Freitas, 2006).

Freitas (2006, p.109) ainda acrescenta:

“É também pela metáfora 'Apolo-deus-sol', significando claridade, luz, dia, que é possível aproximar o mito de Apolo ao pressuposto diurno do discurso da ciência na epistemologia de Bachelard (...) compreenderemos que é como luz que o fogo de Prometeu anima a epistemologia de Bachelard: é a emanação de luz que elevará a consciência do homem, iluminando a estagnação do espírito científico, associada ao realismo e empirismo. Daí que Prometeu, consoante a etimologia, segundo Brandão (2001, p. 166), deriva de "pró", antes e "manthánein", aprender, saber, perceber, significando aquele que é "prévidente", que percebe de antemão."

Matheus foi o mestre que transformou minha relação com a ciência - do fazer científico para o ser-científico. Em suas palavras:

"Nosso mundo é exageradamente racional, cartesiano e mecanicista. Nossas relações com a natureza, nossos semelhantes e o meio ambiente são frias e quase sempre carregadas de interesse imediativo, evidenciando um sentimento profundamente egoísta. O homem precisa se humanizar e aprender a pensar holisticamente para compreender o todo e suas infinitas relações (...) Daí nossa proposta em educação 
ambiental de envolver pessoas a partir da emoção, tocando seus corações, buscando na participação, na simplicidade e no lúdico a verdadeira essência e fazendo-as perceber a nobre condição de seres pensantes críticos e dignos, não de massa de manobra sem ida e passível da manipulação perversa que domina o mundo" (Matheus et al., 2005, p.154)

As aulas com Matheus nos faziam pensar sobre o papel de cada um de nós neste vasto mundo. Suas atitudes como um pai acolhedor, de braços abertos a qualquer dor que fosse, seu olhar sensível sobre os olhos de quem procurava paz. Matheus sempre foi um homem de luz, um homem bondoso, um homem cujas palavras traziam conforto, por mais inóspito o lugar onde fossem proferidas - um mestre.

Uma relação que, segundo Ferreira-Santos e Almeida (2012):

” (...) vai além da tão promulgada execução do ensinoaprendizagem, pois não se trata da preparação de alunos para a prática da cidadania e inserção no mundo do trabalho, como exige a lei e cobra o pragmatismo da produtividade econômica. A relação mestre-discípulo fala antes dos imperativos da existência, aflora sensibilidades, forma pessoas e responde à urgência da vida" (p. 47)

\section{3 - O presente de Alice - a descoberta da maternidade}

Em Alice, a maternidade foi representada como Presente e, daí, podemos iniciar uma discussão do que foi essa primeira experiência como mãe. Eu era ainda muito jovem e a gravidez não foi planejada. Foi mesmo um "presente", que em Alice aparece como algo inesperado e que chega a suas mãos por meio de seu mestre.

O mestre não é pai de Presente, é apenas aquele que viabiliza esse encontro e, como relatado no trecho autobiográfico, 
foi mesmo assim que senti. Matheus, em seu acolhimento e pelos caminhos percorridos em busca do seu encontro, me possibilitou viver esse momento de forma mais confortável. O mestre abrigou Alice em um aposento dentro de sua própria casa, para depois presenteá-la.

Em Alice, este encontro é relatado da seguinte forma: "No dia seguinte, quando Alice abriu os olhos, viu uma cesta no chão. A cesta se mexia e fazia barulhos engraçados... Alice curiosa que era, levantou com cuidado o pano que cobria a cesta. Havia um bebê! Um lindo bebê."

Um bebê deixado dentro de uma cesta à espera de Alice. Durante a investigação de referências que pudessem ajudar na análise das escolhas imagéticas que constituem os contos, me deparei com a similaridade entre este conto e alguns contos mitológicos em que crianças aparecem abandonadas ou surgem de forma "milagrosa" nas histórias. Até então, não tinha consciência de que Presente simbolizava, como descrito, uma criança abandonada.

Durante a escrita, a cena foi se construindo de forma muito poética e carinhosa, de maneira que, ao perceber que havia colocado o que simbolizava meu filho e a maternidade como um abandono, causou certo desconforto. Porém, a questão foi sendo elucidada no estudo sobre o arquétipo da criança divina, descrita por Jung e Kerényi (2011): “A criança divina é, na maioria dos casos, uma criança abandonada (...) Às vezes, o pai é inimigo ou apenas está ausente (...) a mãe desempenha um papel insólito: Ela é e não é, simultaneamente" (Kerényi, 2011, p.49).

Como no conto, Alice é e não é. Alice não é mãe biológica de Presente, já que não o gerou em seu próprio ventre. No 
entanto, Alice assume este papel ao aceitar o Presente que lhe foi deixado. Sim, porque o Presente não é dado pelo seu mestre. Ele apenas o conservou até a chegada de Alice em sua casa. O que podemos também considerar como um aspecto "milagroso" do feito, já que o bebê fica aos cuidados do mestre durante um tempo que não é esclarecido no conto.

Presente é apenas uma representação simbólica do momento, do significado da maternidade e de todas as mudanças que um filho gerou em minha vida. Jung (2011) afirma que:

"Não é o mundo tal como o conhecemos que fala a partir do seu inconsciente, mas o mundo desconhecido da psique, do qual sabemos se reflete apenas em parte de nosso mundo empírico, e que, por outro lado, molda este último de acordo com o pressuposto psíquico. $\mathrm{O}$ arquétipo não provém de fatos físicos, mas descreve como a alma vivencia a realidade física" (p. 114)

A maternidade, o parto, meu nascimento como mãe e meu próprio filho poderiam ter sido representados de inúmeras formas simbólicas, ou seja, a escolha de um bebê deixado em uma cesta foi uma escolha inconsciente que, na verdade, trazia em si a revelação de um estado de transição, de transformação pelo qual eu passei na vida real. E como colocado pelo próprio Jung (2011):

"Um aspecto fundamental do motivo da criança é o seu caráter de futuro. A criança é o futuro em potencial. Por isso, a ocorrência do motivo da criança na psicologia do indivíduo significa em regra geral uma antecipação de desenvolvimentos futuros, mesmo que pareça tratar-se à primeira vista de uma configuração retrospectiva. A vida é um fluxo, um fluir para o futuro e não um dique que estanca e faz refluir”. (p. 127)

A realização do sonho de ser mãe era acompanhada de certa projeção de um ideal de maternidade e infância que eu relacionava com minha própria experiência enquanto filha. Desejava ser mãe para poder exercer uma maternidade de 
excelência, de completude. Projetei-me em meu filho, acolhi de forma a acolher-me, como se aquela criança fosse a possibilidade de eu viver novamente a minha infância, o que poderíamos descrever como um possível renascimento em mim.

Assim, Presente não é representação concreta de "meu filho", mas sim a representação do processo de reconstituir-me, do nascimento de um novo eu. “(...) a criança prepara uma futura transformação da personalidade (...) é portanto, o símbolo de unificação dos opostos, um mediador, ou um portador da salvação, um propiciador de completude" (Jung, 2011, p. 127).

Ser mãe era um sonho de infância, mas no sonho de menina havia um conjunto de elementos de perfeição, aceitação, acolhimento pelo outro e o casamento. $\mathrm{Na}$ experiência vivida, esta idealização de mundo perfeito foi frustrada. $\mathrm{O}$ mundo não me acolheu tal qual eu desejava. Eu me vi sozinha num momento de extrema fragilidade e esta solidão também pode ser motivo dessa “criança abandonada”. Se eu constelo com os personagens que nascem em Alice, Presente é parte de mim, uma parte que nasce e se desenvolve como uma nova estrutura do que me tornei após essa experiência. Eu não estava preparada para viver a experiência, e a criança da cesta simboliza essa superação e aceitação do momento vivido como um passo para a busca da completude, para a autorrealização.

"A “criança” surge nesta situação como um conteúdo simbólico manifestante liberto de pano de fundo (a mãe), isto é, isolado, incluindo às vezes também a mãe na situação perigosa, quando é ameaçado, por um lado, pela atitude de recusa da consciência, e por outro, pelo horror do inconsciente, pronto para devorar de novo todos os seus nascimentos, uma vez que o inconsciente produz estes últimos apenas ludicamente e que a destruição é uma parte inevitável do jogo. Nada no mundo dá as boas-vindas a 
este novo nascimento, mas apesar disso ele é fruto mais precioso e prenhe de futuro da própria natureza originária; significa em última análise um estágio mais avançado de autorrealização". (Jung, 2011, p. 130)

Há ainda uma leitura a se acrescentar. Tendo Presente chegado a Alice pelas mãos de seu mestre e sendo o mestre a representação do meu encontro com Matheus, Presente pode significar, também, o surgimento de uma nova consciência criativa, propiciada pelo contato e aprendizado na experiência que vivi enquanto discípula.

Concomitante à gravidez, trabalhei com Matheus nos projetos de educação ambiental, o que culminou na escrita de um relatório que posteriormente constituiu parte de um livro do qual também fui autora (Matheus et al., 2005). Outra realização pessoal que pode ser representada como Presente, tal qual veremos no próximo conto de Alice.

Presente é a personificação do eu que nasce a partir de sua existência: "A descoberta de Si-Mesmo através do outro no diálogo e na corporeidade é a vivência e o cultivo de uma gravidez" (Ferreira-Santos, 2005b, p. 41). 


\section{4 - Encontro com os mestres - encontro do dia e a noite; o movimento crepuscular da maestria}

Neste conto de Alice houve o encontro entre Alice e seu mestre do saber que, na escrita da autobiografia, simboliza meu encontro real com Matheus, meu mestre diurno. A partir deste momento, vou construindo meu caminho profissional sobre alicerces do aprendizado vivido na companhia desse mestre.

No encontro das linhas de vida, Matheus e Mestre Alcides já viveram esse momento de encontro com seus mestres e vão a partir de agora, iniciar o trabalho de construção de uma vida baseada nos conhecimentos oriundos deste encontro. Mestre Alcides funda o Ceaca - Centro de Estudos e Aplicação da Capoeira; e Matheus elabora e dá início ao Curso de Especialização em Educação Ambiental do CRHEA/USP.

Mestre Alcides em seu relato nos conta esta história: “ $E u$ já era formado do mestre Eli no começo dos anos 8o, e, aí, fui para o cativeiro automaticamente (...) Eu era funcionário da Universidade de São Paulo e não dedicava cem por cento à capoeira, eu tinha que me dedicar à capoeira dentro do meu tempo (...) eu ficava pensando nessa capoeira profissional (...) eu queria fazer um trabalho com a capoeira mais ligado ao lado da cultura, da educação (...) que a gente pudesse levar isso para escola, trabalhar isso no lado mais social, com as crianças (...) porque quando eu comecei capoeira, era mais difícil, você tinha que treinar muito e gostar muito, fazer tudo aquilo e submeter a um treinamento muito forte ou você não ficava e eu achava que a gente tinha que ponderar isso (...) eu queria que a capoeira fosse mais inclusiva. Porque a capoeira antes era exclusiva (...) eu queria fazer uma capoeira que trouxesse as pessoas que 
tinham alguma dificuldade, que tinham algum receio (...) muita gente que queria fazer capoeira, mas tinha medo de capoeira, porque naquela época tinha mestre quebrando e batendo, machucando e as pessoas tinham medo, mas também não queria um nome, assim 'grupo de capoeira tal' (...) Essa coisa de acadêmico, nada contra o acadêmico, mas para capoeira, acho que não... eu queria um outro nome para capoeira, que não fosse grupo e que não fosse academia, aí, eu imaginei um centro de estudos e práticas, aplicação daquilo que se estuda, que é o objetivo do nosso grupo de estudos, um jeito que a gente poderia pesquisar, estudar e colocar isso em prática e que tivesse lugar para todo mundo: 'Eu não quero fazer capoeira, só quero pesquisar capoeira, eu só quero estudar a capoeira' ou então: 'Eu quero fazer capoeira, mas não quero ser capoeirista, eu quero fazer capoeira, eu quero treinar capoeira, mas eu quero...', mas sem perder qualidade, sem perder os fundamentos (...) que a pessoa vá jogar capoeira daquele jeito dela, do ritmo dela, mas ela vai aprender todos os fundamentos, aprender aquelas coisas básicas do respeito, não só com os mestres, com os colegas, com o que já está começando, com o que já está, que tá mais evoluído, ter esse entendimento dentro da capoeira e conhecer esse lado da história oral para juntar com a história escrita. Porque tem coisas que você não vai entender se não está no meio praticando, você não vai entender os seus códigos, as nuances, porque é coisa que não tá escrito em lugar nenhum, por isso é importante a pessoa da pesquisa estar no meio fazendo, visitando, indo aqui, indo ali, somando tudo isso, dá uma visão enorme da capoeira, do que é a capoeira no total, não na especificidade, a gente na capoeira sai 
da roda, entra na roda maior. Eu pensei no Ceaca deste jeito, só que a comunidade vai te pressionando e vai te exigindo isso... $O$ Ceaca não tinha uniforme, não tinha batizado, não tinha corda, não tinha nada, nunca quis pagar um lugar porque uma vez que eu alugo um lugar e preciso do dinheiro para pagar esse lugar com a mensalidade, eu vou ter que abrir mão de alguma coisa dos meus princípios de capoeira... se eu não tiver lugar nenhum para eu dar aula de capoeira, eu vou para rua... eu nunca paguei um lugar para dar aula de capoeira... já recusei um monte de oferta... isso é um negócio doido... não quero, porque eu vou ganhar uma boa grana, mas eu vou me submeter a aceitar algumas coisas fora do meu princípio, da minha filosofia de capoeira... vou ter que comercializar alguma coisa... vou comercializar a capoeira. É meu jeito de visão que vem do congado, não tem academia de congado, é coisa que se faz em casa e sai pela rua e vai na igreja, dança e vai embora para casa e acaba, aquele fundamento ... capoeira para mim é sagrado (...) eu sei que é difícil, mas não é impossível”.

A maestria de Mestre Alcides se inicia aqui, na sua forma de ver a capoeira, na sua forma de conduzir seu grupo, na filosofia tradicional griot (Hampate Bá, 2010) de manter o legado da sua ancestralidade sobre fundamentos da cultura tradicional popular, na manutenção da oralidade e do caráter democrático. Mestre Alcides inicia uma nova linhagem de capoeira. A capoeira não é lugar de estar, é lugar de ser. Há espaço para todos, há acolhimento e respeito à diversidade e aos fundamentos. Mestre Alcides rompe com o pensamento pragmático ao qual estava inserida a capoeira que viveu, para iniciar um trabalho de resgate da capoeira enquanto manifestação de resistência de um povo. 
Algo parecido parece se manifestar no discurso de Matheus, ao nos contar sobre a criação do Curso de Especialização em Educação Ambiental: "Eu percebi que educação ambiental era muito mais que meio ambiente, era mais social, político... comecei a imaginar uma coisa diferente, imaginar uma coisa transformadora, que pudesse transformar as mentes... que é a educação ambiental. Era essa a ideia inicial, eu comecei a pensar nesse curso de educação ambiental como uma coisa transformadora... não ficou apenas passar conceitos de meio ambiente, mas que tivesse um envolvimento maior, que as pessoas que fizessem o curso fossem transformadas para melhor, sabe?... suas vidas, não só como profissional, mas como pessoas porque eu estava observando nesses cursos anteriores, que tinha essa demanda, uma carência muito grande (...) o primeiro curso foi muito técnico (...) dez disciplinas técnicas... recurso hídrico, limnologia geral, tratamento de águas residuais... era o universo que a gente tinha aqui... aí, que que eu fiz? Eu fui até Guarapari, estava tendo o fórum... eu fiquei sabendo que o Marcos Reigota estaria lá... ia ser um dos palestrantes de mesa-redonda, eu falei: 'Ah, vou lá conversar com este cara, vou trazer este cara para o curso aqui'... No intervalo, eu chamei, bati um papo com ele, almoçamos juntos e eu falei da minha proposta, daí, ele veio, com o maior prazer, veio e até hoje ele vem, eu fui chamando outros (...) trazia gente da área de educação, da didática, da pedagógica e o curso foi sendo transformado (...) estava sempre antenado para trazer gente para o curso aqui, todo evento que eu ia, tinha um palestrante. 'Pô, esse cara serve!' Eu meio que mentalizei um curso que mexesse nas pessoas... aí, eu trouxe o Yossef lá de 
Taubaté... psicólogo lá meio doido, mas era um cara que trazia coisas interessantes, para mexer um pouco com as pessoas $e$ assim foi (...) até hoje a gente não para, a gente continua montando o curso, a gente nunca para, o curso não acabou, o curso está sempre se transformando porque não tem como ficar parado."

Matheus, em algum momento, percebe que deseja algo a mais, que a Educação Ambiental que era praticada e ensinada no CHREA se restringia a determinados aspectos que a reduziam em disciplina. E Matheus enxergava algo a mais, algo de mais humano, de mais valoroso enquanto processo formativo e político. Matheus viu na Educação Ambiental, uma forma de transformar o mundo a partir da transformação das pessoas.

Aqui se dá o ponto de encontro das linhas de vida entre esses dois mestres na constituição de suas maestrias. O olhar da razão é superado por um olhar poético, sensível, humano.

"Ao compreender a importância das mediações simbólicas, valorizar o repertório cultural do outro, iniciando práticas dialógicas com a profundidade da exemplar busca pessoal de coerência entre a prática e o discurso, e transitar entre as várias culturas (práticas simbólicas de vários povos em tempos e espaços diferentes) para a cultura (no seu sentido agrário) da Cultura (patrimônio universal do humano); é que acreditamos constelar as práxis do que denomino de práticas crepusculares, trânsito entre dois registros de sensibilidade, diurno e noturno, ampliando e refinando a própria sensibilidade. Trata-se de uma contribuição ao processo de reencantamento (Betzauberung) do mundo com um processo de iniciação mítica, onde o engendramento de Mestres (no sentido de Gusdorf) se dá na retomada do caminho mítico para maestria. Não assunção do caminho do mestre, mas percepção e apropriação do seu próprio caminho para maestria (Ferreira-Santos, 2005b, p. 41) 


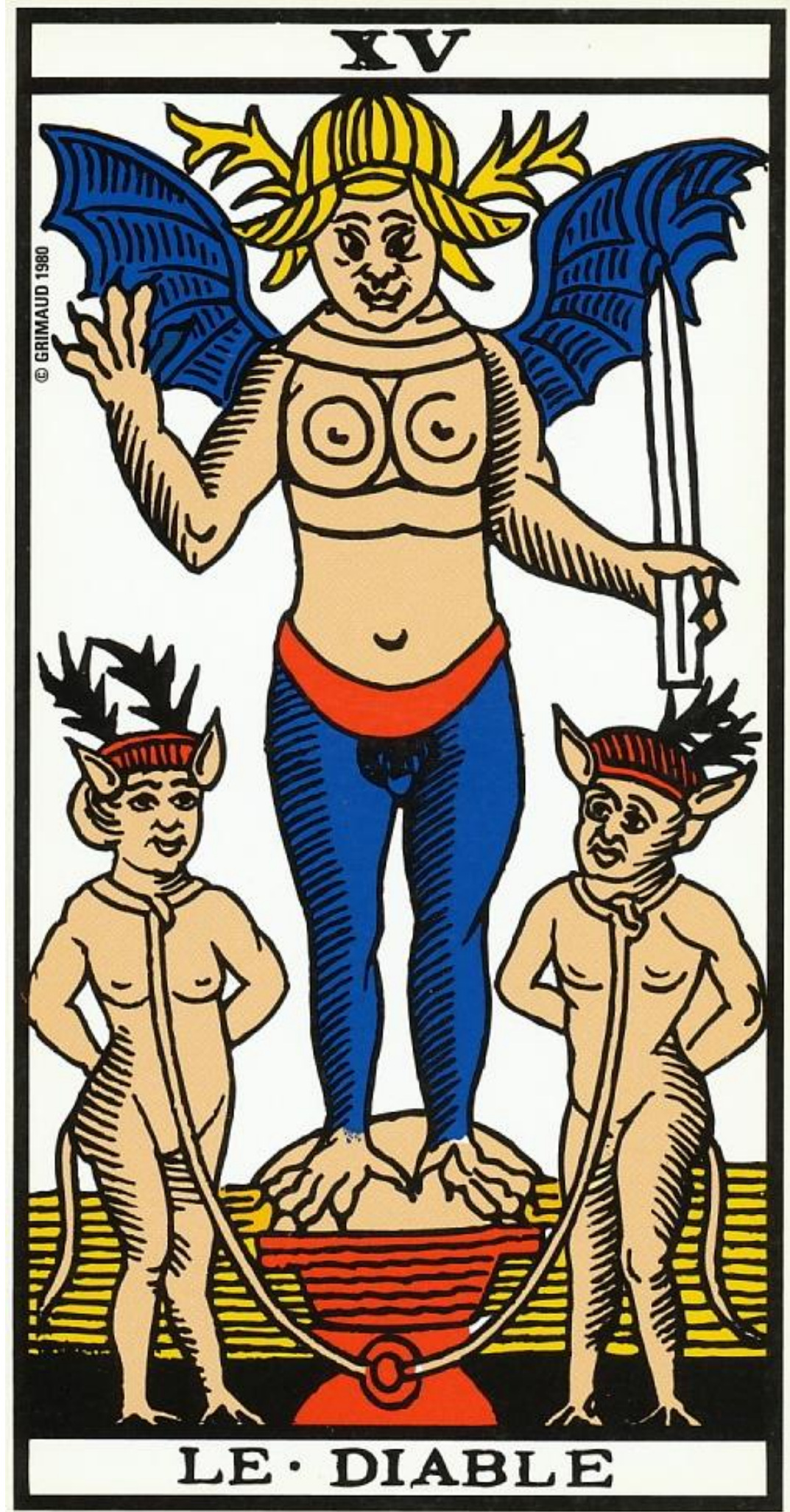




\section{5 - Alice nas trevas}

Alice não podia negar, ela era a pessoa mais feliz do mundo ao lado de Presente e Castigo. Presente era um bebê calmo, risonho que trazia paz ao coração de Alice. Apesar de dar muito trabalho, Alice se sentia preenchida, se sentia completa.

Alice resolveu montar morada perto de um lago. Achou que seria bom para Presente que pudesse crescer perto da água, observando os peixes, brincando com os patos. O Sol se punha no horizonte em frente à casa de Alice e todo fim de tarde, sentavam os três para apreciar tamanha beleza.

Certo dia, a noite não acabou. Alice demorou a entender o que se passava. O relógio despertou e já era hora de levantar, mas nada do Sol raiar. Alice ficou preocupada, não abriu a porta de casa e não deixou que Presente saísse para brincar.

Foram passando as horas, foram passando os dias $e$ nada da noite passar. Alice entrou em desespero. O que faria diante de tanto breu. As velas já iam se acabando e logo ela não poderia mais cuidar de Presente e de Castigo. Alice foi enlouquecendo de medo, de pânico, de pavor por ver cada vez menos.

Ela criou coragem, deixou Castigo cuidando de Presente e saiu sozinha, tentando resolver a situação... Andou, andou, andou. Alice caiu num buraco sem fim e caindo, caindo foi vendo uma luz. Era o Sol que havia pego caminho errado e raiado num buraco de rã. 
Alice pegou o Sol pela mão e o foi puxando... À medida que escalava o buraco, o dia ia clareando. As luzes do Sol iam surgindo e o dia ia voltando para o seu lugar. Não foi fácil.

Alice ficou exausta, mas conseguiu colocar as coisas no lugar. O Sol voltou a brilhar e o dia voltou a nascer. 


\section{1 - O deserto sem Sol - as perdas e os danos}

Em agosto de 2002, nasceu meu filho... "quando seu moço, nasceu o rebento, já era hora dele respirar... " (Chico Buarque, 1981). João Pedro chegou ao mundo de parto natural. Meu médico (André) foi meu maior parceiro nesta hora e em toda a preparação dela. André ficou comigo no hospital durante todo o trabalho de parto e fez minha hora ser mais gentil.

A avó do meu filho foi para São Carlos me ajudar nos primeiros momentos. Recebi a visita da minha família, que ficou dois dias e se foi. Os avós do meu filho me levaram para sua casa e lá fiquei os dois primeiros meses do puerpério. Foi este acolhimento que me deu suporte para iniciar a vida como mãe. Sou eternamente grata a eles.

Em outubro, voltei para São Carlos. Éramos nós dois, eu e meu pequeno João Pedro. Tentei retomar a vida na universidade e as atividades com o grupo de teatro, mas cuidar sozinha de um bebê tão novo não era das tarefas mais fáceis. Pensava em mudar para Sorocaba e morar com o pai do meu filho, mas havia resistência de sua parte.

Depois de muito insistir, acabamos alugando uma casa e eu me mudei em dezembro. Abandonei os planos de iniciar o mestrado em 2003, para me dedicar à família que eu pretendia formar. Uma fantasia.

Fiquei nesse relacionamento por dois anos. A dor pela frustração do casamento falido era tão grande que me paralisava e não me deixava sair dele. Minha vida era um caos. Minha realização se dava pelo trabalho e pelo cuidado com meu filho. 
Em julho desse mesmo ano, Matheus me ligou comunicando que nosso projeto havia se transformado em livro. Eu entraria como uma das autoras do trabalho e o lançamento da primeira edição seria em julho. Fui para São Carlos sozinha. Era a primeira vez que eu estava fora de casa, sem filho para me dedicar a algo exclusivamente meu.

O lançamento do livro, o reencontro com amigos do curso de especialização e com Matheus me levaram ao reencontro de mim mesma, ao reencontro do que eu podia e queria ser como pessoa, dos meus sonhos e das lembranças do quanto eu era feliz antes do casamento. Voltei para casa para recomeçar uma nova vida. Logo me separei e reiniciei a jornada na busca dos meus sonhos esquecidos.

Neste conto de Alice, podemos trabalhar a partir de alguns obstáculos superados por Alice: a maternagem, a desilusão de um casamento desfeito e a reconquista da rota perdida na busca pelas conquistas pessoais e profissionais.

\section{2 - O Sol - a reconquista da própria vida}

Para entender como elaborei este conto de Alice a partir da autobiografia, buscarei analisar alguns símbolos que aparecem em Alice como representação de momentos muito significativos deste capítulo da vida.

O primeiro deles é o Sol e sua ausência, representada pelas trevas. A saga de Alice começa em uma cena quase bucólica e de mansidão na escolha do lugar para criar Presente. É dito que Alice esta muito feliz e realizada até o dia em que o dia não nasce. Não há Sol, não há luz, há escuridão e medo. 
Jung (1962) nos convida a uma reflexão sobre a imagem do Sol e sua representação arquetípica:

“(...) nos conduzo a uma minuciosa investigação da aspiração ao Sol, baseado em ideias mitológicas (...) o deus-criador, cuja natureza dual se põem em relevo (...) encontrando assim, mais além das análises morais, uma expressão natural no luminoso pai celestial e no diabo (...) O Sol é na verdade a única imagem razoável de deus, tanto se nos colocamos no ponto de vista do primitivo como na ciência moderna da natureza; sempre é o deus-pai que anima a todo vivente, o fecundador e o criador, a fonte de energia do nosso mundo. No Sol como coisa natural que não conhece cisão interna alguma, pode resolver harmonicamente a contradição em que caiu a alma do homem. E não só é benéfico, posto que também pode destruir; daí que a imagem zodiacal do verão ardente seja o leão devorador de rebanhos ao qual da morte do herói judeu Sansão para redimir dessa praga a desfalecente terra. Mas a natureza peculiar do Sol é que queime e ao homem lhe parece natural que assim seja. Também resplandece por igual o justo e injusto, e se faz crer o mesmo ao ser útil e nocivo. Em consequência resulta adequado para representar o deus visível deste mundo, quer dizer, a força impulsora da nossa própria alma, a libido, cuja essência está em produzir o útil e o nocivo, o bom e o mal. Os místicos nos ensinaram que esta comparação não é um mero jogo de palavras: quando ao reconhecer em si mesmo a descida às profundidades do seu ser, descobrem em seu coração a imagem do Sol, encontrando assim, sua própria vontade de viver, que com direito - eu que em virtude de um direito físico - chamam Sol, posto que este é fonte de energia e vida. Assim, nossa vida fisiológica, como processo energético, é essencialmente Sol (Jung, 1962,p. 136137).

A partir da leitura simbólica junguiana, o Sol aparece em Alice como representação de força vital, de sua própria vontade de viver. Do Sol depende seu cotidiano, assim afetado pela ausência inesperada do astro-rei. Os dias de Alice se transformam em uma noite eterna, mas não uma noite poética, fecunda, acolhedora. Uma noite como trevas, onde a ausência de luz é significado de medo e pânico.

Alice, num ato de proteção, fecha a porta para que Castigo e Presente não sejam expostos aos perigos da noite: 
“O arquétipo da casa é fortemente terrestre, registram os apelos celestes pelo regime diurno da imagem (...) a casa que abriga é sempre um abrigo que defende e protege e que se passa continuamente da sua passividade à sua energia defensiva" (Durand, 2012, p. 169).

Quanto à representação da noite eterna ou das trevas nefastas no qual se encontram Alice, Castigo e Presente -. As trevas constituem uma ambivalência terrificante motivada por uma "abstração espontânea tão valorizada pelo homem" (Durand, 2012, p. 90). Segundo o autor, esta seria a representação pura do fenômeno da angústia.

" (...) baseada no medo infantil do negrume, símbolo de um temor fundamental do risco natural, acompanhado de um sentimento de culpabilidade (...) sendo a visão tenebrosa sempre uma reação depressiva (...) No folclore, a hora do fim do dia, ou a meia-noite sinistra, deixa numerosas marcas terrificantes: é a hora em que os animais maléficos e monstros infernais se apoderam dos corpos e das almas. Esta imaginação das trevas nefastas parece ser um dado fundamental, opondo-se a imaginação da luz e do dia”. (Durand, 2012, p. 91)

Quando mudei para Sorocaba, optei por abandonar sonhos acadêmicos e profissionais. Abandonei projetos em andamento para me dedicar à realização de um sonho infantil idealizado da construção de uma família "perfeita”. A realidade da maternidade, a solidão e o abandono vivido no relacionamento trouxeram sentimentos de angústia, tristeza e depressão. Sentia profundo arrependimento pelas escolhas tomadas, me culpava pelas perdas e não conseguia buscar alternativas que propiciassem mudanças. Vivi nas trevas. Busquei por ajuda terapêutica para tomar alguma atitude, este foi o ato de coragem.

Em Alice, essa energia defensiva é reforçada no ato de coragem ao se expor em busca de alguma resposta, de alguma explicação para a ausência de luz. Porém, Alice segue sem 
proteção nenhuma, segue desarmada para os possíveis perigos que pudesse enfrentar. $O$ que, em si, parece um ato de resignação. Como poderia Alice se expor de tal forma?

Alice anda até "cair" em um buraco de rã. Alice cai. O cair não é ato intencional, o cair é sempre veloz, abrupto e repentino. Alice cai no interior do buraco... "caí no buraco dentro mim". Este contato despreparado com o íntimo, sem tempo para assimilação do devir ou uma não aceitação da condição temporal, um não se desprender do medo (Durand, 2012).

Essa dualidade simbólica, dia x noite, ascensão e queda, medo e coragem, presente neste conto de Alice são traços estruturais típicos do regime diurno de imagens proposto por Durand, (2012) dentro de uma estrutura esquizomórfica. Ainda segundo o mesmo autor,

"Podemos, com efeito, reconhecer nesta descrição os traços mais típicos do Regime Diurno da imagem. 'O racional', escreve Minkwski, 'compraz-se no abstrato, no imóvel, no sólido, no rígido; o movente e o intuitivo escapam-lhe; pensa mais do que sente e apreende de maneira imediata; é frio, tal como o mundo abstrato; discerne e separa, e por isso, os objetos, com seus contornos nítidos, ocupam no seu lugar de mundo um lugar privilegiado. Assim chega à precisão da forma... ' É sentando em perspectiva, subtendendo o processo diairético, todo labor paciente dos métodos que através de longas cadeias de razões pretendem dar conta da transcendência. Esse racionalismo extremo e, no limite, mórbido deixa bem claras as estruturas esquizomorfas do Regime Diurno da representação" (p. 185)

Neste conto de Alice não há ressonâncias com as histórias dos mestres. 


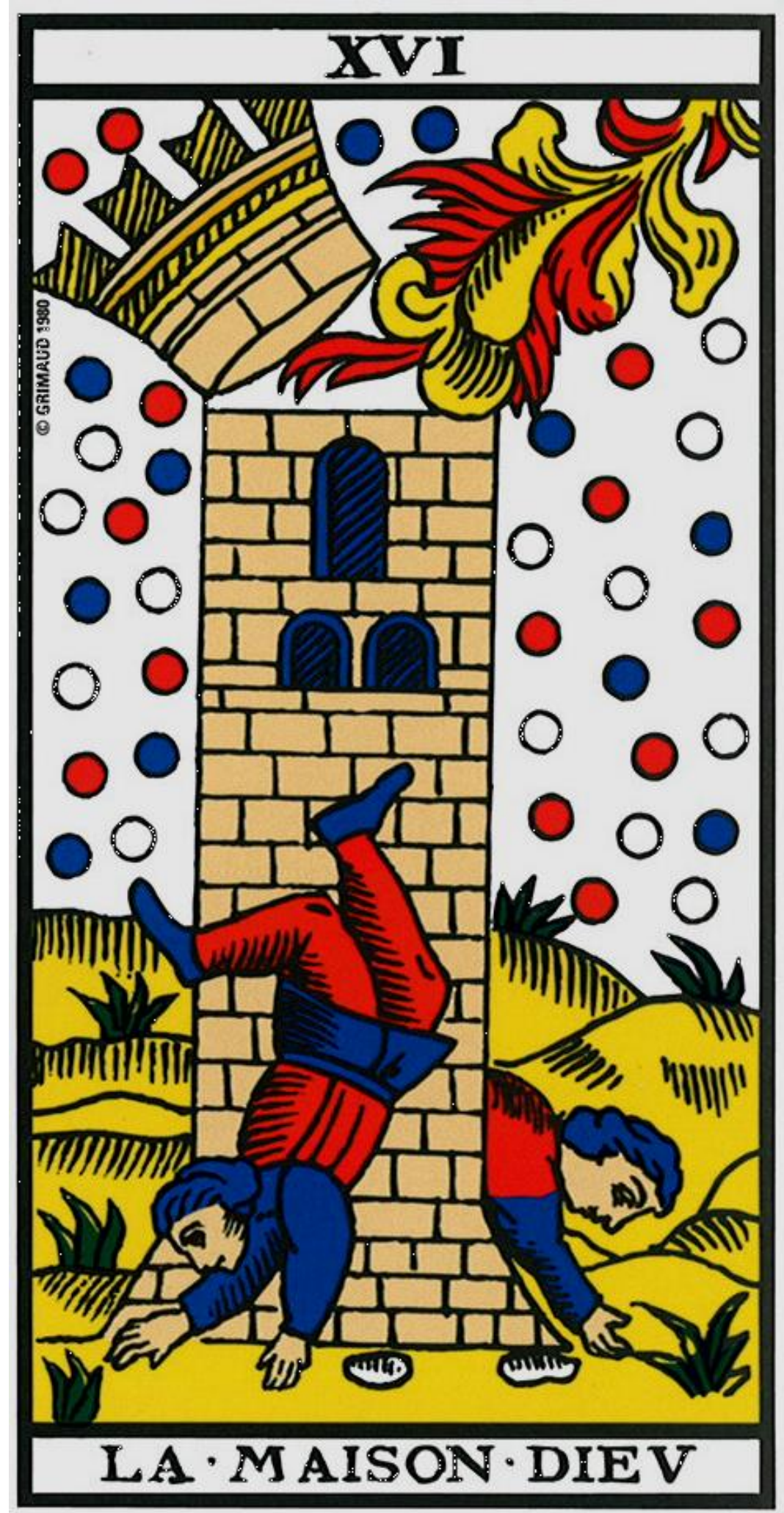




\section{6 - Alice e o velho preto de luz}

Alice viveu muito. Viu Presente crescer e Castigo envelhecer. Castigo já não era mais aquele cão de dentes grandes e afiados. Os dentes haviam caído e ele andava cada vez mais cansado, cada vez menos podia seguir os passos de Alice.

Alice morou em muitas casas, conheceu muitas pessoas, andou com muitas outras bruxas. Alice se conhecia cada vez mais, Alice amadurecera e já não havia mais traços de menina em seu corpo de mulher.

Alice buscou por novos conhecimentos, aprendeu a ler melhor o mundo e ficou muito boa com as palavras. Alice era agora uma bruxa cuja magia estava nas histórias que contava... O mundo foi ficando chato e Alice percebeu que algo faltava. Era algo que havia perdido, algo que havia ficado pelo caminho. Alice nem se lembrava mais das histórias de quando era menina, de quando era uma quase borboleta que brincava entre os meninos de luz.

Um dia, Alice encontrou um velho preto de luz que cantava músicas como Alice nunca tinha visto antes. Ele tocava um instrumento que Alice não conhecia e dizia sobre um tempo em que muitos outros velhos pretos de luz habitavam aquele lugar. Ele morava embaixo de uma enorme árvore e andava com um bando de outros homens e meninos que precisavam ouvir suas histórias para ficarem mais fortes.

Era um bando de guerreiros que se preparavam para uma batalha. Queriam tomar de volta um lugar que lhes haviam roubado. Alice ficou fascinada com aquele bando $e$ 
pediu ao velho preto de luz que lhe desse permissão para seguir com eles.

$O$ velho disse que sim e, daquele momento em diante, Alice aprenderia a ser guerreira. Essa nunca foi uma vontade de Alice, mas de alguma forma tudo que havia vivido havia the dado força e coragem para vencer uma guerra. De Alice, ninguém nunca tirou terra nenhuma, mas Alice sempre se sentiu sem terra, sem lugar, sem um teto para chamar de seu. Talvez Alice tenha nascido sem chão e encontrar um bando que lutava por este chão, tenha dado a Alice o que lhe faltava.

Para seguir com o bando, Alice deveria largar tudo que havia conquistado. Deveria ser forte e acreditar que no final, tudo valeria a pena. Alice se mudou para o pé da árvore e levou com ela Presente e Castigo. Castigo deixou de acompanhar Alice em suas andanças com o velho preto e seu bando. Ficava sempre a esperá-los, deitado na sombra do grande Iroco. 


\section{1 - A cidade caixa de concreto}

Este conto de Alice se refere ao período pós-separação. Agora, éramos só eu e meu pequeno filho na vida. $\mathrm{Na}$ reorganização profissional, consegui algumas aulas em uma escola estadual, o "Estadão”, em Sorocaba, SP.

No segundo semestre de 2006, participei do processo seletivo do programa de pós-graduação da Faculdade de Educação da Universidade de São Paulo. O processo foi dividido em três etapas: uma prova específica, análise de projeto e entrevista.

Aprovada nas duas primeiras fases, tive muito medo da entrevista. Havia passado por nove processos seletivos e essa fase era sempre a barreira que não conseguia transpor. Durante a entrevista, seguiram-se as perguntas básicas feitas em todas as outras e acabei citando minha "experiência" em processos seletivos. Assustados com a trajetória, a banca questionou: "Mas você acha que não passa nas entrevistas, por quê? ". Eu respondi "porque digo algo que não deveria dizer". Este “algo" era minha preferência por dar continuidade à carreira na Educação Ambiental.

$\mathrm{Na}$ décima tentativa em processos seletivos para o mestrado, disse à banca que aceitaria trabalhar em outra área e com outros projetos. Assim, fui finalmente, aprovada.

A indicação de orientação ficaria sob responsabilidade da própria banca, ou seja, não sabia quem iria me orientar até o início efetivo do curso.

Conheci minha orientadora em uma reunião de orientação, em que conversaríamos sobre o projeto de mestrado, 
sobre a linha de pesquisa, sobre as dinâmicas do grupo de estudos. Nessa reunião, ficou acordado que não seria possível continuar na minha área, já que este não era o foco do grupo. Nesse dia, ou a partir dele, fui me distanciando da trajetória profissional que havia traçado durante a vida acadêmica.

Este "abandono" por uma vida investida em algo que fazia muito sentido para mim teve um preço alto. Não me identificava com o grupo de estudos, com as questões ali colocadas, com as referências que deveria ler. Não via sentido para as pesquisas feitas, nem mesmo conseguia ver a importância social do que era produzido.

Eu sempre tive essa preocupação com o "sentido social" das pesquisas acadêmicas e estar em um lugar onde nada fazia sentido, era muito difícil. Tão difícil, que esse processo de adaptação me levou ao pânico. Em 2007, tive doença do pânico, algo descrito na literatura médica como a pior sensação que um ser humano pode ter ao longo da vida. Aos poucos, fui me inserindo e me reestabelecendo dentro de uma nova realidade.

Em 2008, fiz duas disciplinas que mudariam a minha relação com a pós e que, na verdade, já traziam prenúncios desta tese que aqui se apresenta. Cursei a disciplina de Análise de Discurso e de Semiótica na Faculdade de Filosofia Letras e Ciências Humanas da USP, a FFLCH. Conheci autores como Focault, Pêcheux, Mangueneu, Saussure, Greimas... Encontrei uma via por onde transitar com mais prazer na pesquisa.

Durante o ano de 2007, havia decidido trabalhar com o estudo do discurso dos monitores nos centros de ciências, por conta da minha experiência como monitora em diversas instituições e quando entrei em contato com estes autores, vi que 
minha pesquisa poderia ter algum dialogo mais profundo com questões sociais e com a compreensão de estruturas de poder que eram de meu interesse.

Em 2009, mudei para São Paulo. Havia conseguido uma bolsa do CNPq e reencontrado uma amiga que também fazia pós na USP. Decidimos morar juntas com nossos filhos. Nossa realidade era parecida, éramos mães solteiras de meninos e com pouca participação familiar. Achamos que poderíamos nos ajudar.

A Andréa (parceira da casa) tinha uma rotina de trabalho e pesquisa que a impossibilitava de ficar em casa. Assim, nossos planos sobre dividir tarefas, conviver, criar filhos juntas... foram desfeitos e passamos apenas a dividir as contas da casa.

A defesa da dissertação foi em 5 de abril de 2010. Foi um dos dias mais estranhos da minha vida. Na minha defesa havia sete pessoas. Cinco pessoas do grupo de pesquisa e meus tios. Foi estranho não contar com a presença de melhores amigos e a família. O vazio maior se deu após a defesa. Quando acabou, sai da sala, fui para o laboratório, vi meus e-mails e fui para casa, andando e sozinha. Pensando o que significava aquilo. Então era só isso? Nada fazia sentido. Não sentia orgulho de mim e nem do meu trabalho, não vi nada de especial e senti um profundo vazio... Não me sentia mestre de nada.

Logo, eu estava no processo seletivo do doutorado. Estudando para passar na prova de proficiência. Consegui uma bolsa para trabalhar num projeto de pesquisa do grupo e fui convidada para trabalhar no programa de formação de professores do Redefor, da USP. 
Quando prestei o doutorado em 2010, não fui aprovada na prova de línguas. Em 2011, prestei novamente e, dessa vez, fui aprovada para trabalhar com a mesma orientação e no mesmo grupo do mestrado. Mais uma vez tive crise de pânico.

Em 2011, seguia com meus trabalhos, em embates discursivos e subjetivos com minha orientadora, que sempre alertava que eu não iria trabalhar com o que eu queria. Se não fosse algo referente aos seus interesses de pesquisa, ela não me orientaria.

Em julho desse mesmo ano, conheci um rapaz negro e me apaixonei. Este romance vem à tese, porque por meio deste relacionamento acabei procurando por "memórias perdidas" ao longo da vida.

Depois daquela situação da adolescência em que fui descriminada pela família e amigos por namorar um jovem negro, passei a não enxergar os negros como possibilidade de relacionamento. Os homens negros ficaram invisíveis para o meu coração. Assim, quando enxerguei o Léo, enxerguei também um passado negado. Eu havia sido criança de cortiço, cresci entre pretos no samba, era menina de "boteco", frequentava a umbanda... E em algum momento da vida o tambor calou dentro de mim.

O Léo, sem querer, me trouxe de volta o que havia ficado no caminho. Ele era baiano e, por ele, quis saber mais de sua cultura e minha ignorância apenas apontou a capoeira. Assim passei a fazer aulas no CEACA com o Mestre Alcides. Mestre Alcides me recebeu como um pai, literalmente me acolheu e em muito pouco tempo eu já fazia parte da família. 
Dizem que a "capoeira é um bichinho que quando pica a gente, nunca mais a gente vive sem”. Capoeira não é jogo, não é luta, não é dança. Capoeira é cultura e tradição. É a história do nosso povo e a resistência contra o sistema. Fui ficando fascinada pela força deste movimento.

Mestre Alcides não dá aulas de capoeira apenas, Mestre Alcides é um mestre griot... um ponto de luz. Mestres griots são mestres de cultura de tradição oral e suas aulas nunca são só de movimento, suas aulas são contações de estórias dos antepassados, da escravidão, da ancestralidade... de nossa identidade.

Assim foi que dentro de mim começou a brotar um desejo imenso de olhar isso melhor, entender o que são esses pontos de resistência culturais que mantêm viva nossa identidade, de maneira tão silenciosa e discreta, mas com tanta força.

Meu interesse se distanciava cada vez mais das minhas pesquisas com a academia. Como já havia me conformado que a pós-graduação era só para conquista de um título, comecei a buscar meu prazer de estudo e pesquisa em outros lugares.

No início de 2012, estava escrevendo projeto com o Mestre Alcides, ajudando na organização de documentos e eventos. Nesse mesmo ano, acabei tendo uma discussão sobre o projeto de pesquisa do doutorado com minha orientadora e saí profundamente frustrada com a conversa.

Naquele dia, fui para casa pensando sobre minha vida e minhas escolhas. Pensando sobre o que gostava de fazer, sobre o quanto valia ou não a pena aquilo tudo. Pensei sobre o significado do mestrado e do doutorado, sobre como seria ficar mais cinco anos trabalhando com uma coisa na qual não 
acreditava. Pensando em minhas paixões, nos brilhos dos meus olhos... na alegria que tinha no trabalho com o Ceaca e veio a questão: "Carla, tudo bem pra você largar o doutorado?”

"- Sim, tudo bem."

Esta foi uma das decisões mais importantes da minha vida. Nessa hora comecei a pensar sobre como trilhar o futuro e que novos sonhos e planos poderiam ocupar aquele lugar do doutorado. O que eu poderia fazer e como poderia voltar a trabalhar com coisas que me dessem mais prazer.

Pensei em procurar alguma linha de pesquisa em algum departamento com algum professor que se interessasse por questões ligadas à cultura tradicional, mais precisamente, com os mestres griots... Tentar entender seu papel social, sua relação com a manutenção da cultura tradicional e ir às raízes.

$\mathrm{Na}$ minha lista de interesses, estava o Lab_Arte, laboratório que sempre apreciei a distancia, desde que entrei na pós. Entrei em contato com o professor Rogério de Almeida que, em um sorriso largo, me apoiou na minha decisão, se dispôs a me ajudar. Mas me orientou que, antes, eu falasse com o Prof. Marcos Ferreira-Santos, pois achava que faria mais sentido uma pesquisa orientada por ele. Mesmo não tendo saído de lá com um sim completo, me senti acolhida.

Marquei uma conversa com o professor Marcos, contei todo o ocorrido e perguntei se ele tinha interesse em me orientar. Ele disse: "Sim".

No primeiro semestre de 2012, eu estava matriculada em duas disciplinas. Em uma delas, com a Profa. Diana Vidal, acabei encontrando muita relação com meus novos interesses de 
pesquisa. Meu trabalho de conclusão deste curso foi na área de Antropologia da Educação.

Em uma reunião com Marcos, em 2013, conversando sobre meu memorial, ele sugeriu que minha pesquisa fosse sobre minha história de vida. Apesar de parecer estranho e sem relação com o que havia proposto quando o procurei, vi sentido na proposta. Pensar sobre minha história, a minha trajetória e o quanto meus mestres haviam influenciado na formação de quem sou, proporcionaria a compreensão de como nossas experiências de vida nos fazem ser quem somos. Assim, começa a escrita desta tese.

\section{2 - Vidas secas - sobre os caminhos perdidos}

Este conto de Alice traz muitos pontos de cisão e reencontro. Foi uma fase da vida em que tentei seguir por caminhos que não eram meus e me levaram a uma vida seca, sem sentido e sem alegrias; na verdade, uma continuação do ponto em que paramos no conto anterior.

Aquela vida cheia de angústia, onde o Sol se perde, assim como minha própria vontade de viver, foi resgatada a qualquer custo, como colocado no conto em que Alice com muito esforço, traz o Sol de volta ao seu lugar. Na vida real foi assim, muito trabalhosamente tentei resgatar meus sonhos e minha caminhada.

Decidi que enfrentaria o que fosse, com determinação para realizar e essa decisão se concretizou na aceitação em viver em um lugar que não me pertencia. Minha alma estava seca e sedenta por vida, precisava de alguma forma me reaver comigo, 
me perdoar pelas escolhas equivocadas e me oferecer alguma possibilidade de satisfação.

No conto anterior, que, em análise, se mostrou frio e racional diante da dualidade explícita em imagens, mostra também a forma como neste momento me coloco no mundo. De alguma forma, algo em mim se apagou, passei a ver a vida como um objetivo a ser alcançado. Peguei a vida pelas mãos como uma massa a ser moldada. Sentia um profundo desejo de ser aceita, de ser certa, de caber em alguma fôrma.

Estés (1999) diz que esta é a situação da mulher cuja alma está "faminta”. A autora esclarece:

"Nessa situação, a mulher arde de fome por qualquer coisa que a faça voltar a se sentir viva. A mulher que foi capturada não sabe $o$ que fazer e aceita alguma coisa, qualquer coisa, que lhe pareça semelhante ao tesouro original, seja para o seu bem ou não (...) Nesse estado, ela aceita qualquer alimento independente das suas condições e dos seus efeitos porque está tentando compensar perdas anteriores". (p.171)

Foi com essa alma faminta que entrei na pós-graduação. Também estava presa à um arquétipo de mulher-perfeita. Um modelo a ser alcançado de beleza, profissão, conquista material e intelectual. Fiquei presa a uma fantasia.

"Quando as mulheres são relegadas a disposições de ânimo, a maneirismos e a contornos que se amoldam a um único ideal de beleza e de comportamento, elas se tornam cativas tanto no corpo quanto na alma, não gozando mais de liberdade" (Estés, 1999,p.149).

O grupo de estudos que passei a frequentar na USP, passou a ser meus olhos externos. Sentia como se as pessoas me avaliassem no modo de ser, de vestir, de falar, de pensar e algo me dizia que eu não era aceita, que eu não tinha o tamanho adequado para aquele mundo. Assim, entrei voluntariamente no cativeiro. 
Estava presa em modelos, formas, cores e palavras que precisava obedecer. $\mathrm{O}$ mundo do lado de fora ficou mais importante, porque por dentro eu estava enfraquecida. O sentirme derrotada diante da experiência no casamento e nos processos seletivos para entrada do mestrado, me fizeram acreditar que algo em mim estava errado, que eu precisava mudar e me adaptar.

"Somos influenciados por inúmeros coletivos, tanto pelos grupos aos quais nos associamos quanto por aqueles dos quais não somos integrantes. Sejam os grupos que nos cercam de natureza acadêmica, espiritual, financeira, profissional, familiar, quer de alguma outra natureza, eles impõem poderosas recompensas e punições a seus membros e aos não-membros com idêntica aplicação. Eles operam de modo a influenciar e controlar todas as áreas possíveis - desde os nossos pensamentos até a nossa escolha de parceiros e o trabalho da nossa vida. Eles podem também depreciar ou desestimular os esforços que não se harmonizem com as suas preferências" (Estés, 1999,p.169).

Passei seis anos da minha vida tentando ser quem eu não era. Esta busca cega me fez sentir extremamente sozinha. Uma angústia tomava conta de mim como um buraco que engole a terra. Algo do lado de dentro gritava e saía em forma de crises de pânico. Senti literalmente a morte em mim. Muitas foram as vezes em que chorei desesperadamente, gritando que estava morrendo.

Eu estava morrendo. Matava a cada dia o meu eu, calava minha alma, apagava minha chama interior, negava minha Baba Yaga. Estés (1999) quase fala para mim ao trazer esta questão:

"Se a mulher tenta fazer parte de uma organização, associação ou família que deixe de examiná-la para ver do que ela é feita, que deixe de se perguntar o que faz essa pessoa funcionar e que não se esforce para desafiá-la ou incentivá-la de nenhum modo positivo... sua capacidade de prosperar e criar fica reduzida. Quanto piores as circunstâncias, mais empurrada ela será na direção de uma terra estéril onde foi espalhado sal para que nada ali crescesse. " (p.170). 
Mas, ouvi o grito. No primeiro ano do doutorado, tendo sobrevivido à fome do cativeiro, dei meu grito de libertação ao procurar uma outra forma de me realizar na vida. Esse grito não foi dado ao acaso, ele veio pela batida do coração no pulsar do tambor. O grito veio depois do encontro com meu segundo mestre, que aqui chamarei de "mestre crepuscular": Mestre Alcides.

\section{3 - O mestre preto de luz - a ancestralidade africana}

Neste conto de Alice, vamos trabalhar sobre o encontro com o Velho preto de luz e dos guerreiros. E sobre o simbólico construído nas imagens do canto como um chamado e da mudança de Alice para os pés da grande árvore.

$\mathrm{Na}$ busca por mim, acabei encontrando Mestre Alcides. Diz Estés (1999)

"O mestre vem quando a alma chama - e graças a Deus que isso aconteça, pois, o ego nunca está perfeitamente pronto. Se dependesse apenas do preparo do ego o fato de o mestre ser atraído até nós, permaneceríamos essencialmente sem mestres pela vida afora. Somos abençoados, já que a alma continua transmitindo seu desejo ignorando as opiniões inconstantes do ego." (p.120).

Minha alma estava pronta e ouvi o chamado.

A capoeira entrou na minha vida como a própria vida que precisava renascer em mim. Das primeiras aulas, lembro do sorriso do Mestre Alcides. Ele era duro e assertivo, chamava para o centro durante todo o tempo. Era pelo centro de mim que estava procurando.

As primeiras dificuldades trouxeram as primeiras percepções sobre o que precisava mudar. O corpo estava duro, eu 
mal o conhecia. Tinha medo de realizar os movimentos, tinha medo de morrer. Uma risada nervosa sempre me acompanhava, como uma distração para as coisas que eu ainda não podia ver. Não conseguia colocar as mãos no chão e olhar o mundo de cabeça para baixo. Estava completamente enrijecida pela forma de ver o mundo de um único lugar.

"Estes elementos corporais de comunicação entre todos os sentidos (visão, audição, olfato, cinestesia, tato, intuição) são organizados, nesta tradição cultural afrodescendente, com uma outra racionalidade distinta da tradição europeia brancocartesiana-aristotélica. Esta outra racionalidade se pauta muito mais pela conciliação de contrários (harmonia conflitual que não escamoteia os conflitos, mas os media em relação dialética), pela noção de trajetividade, pela mediação e estruturação narrativa. Nesta outra racionalidade, podemos afirmar que a linguagem gestual negra afrodescendente é, na realidade e em profundidade, a gesticulação cultural de uma corporeidade integral e ainda não-dissociada pela discriminação reflexiva de natureza verbal de tradição europeia branca e escrita...assim, tudo acaba em canto e em dança." (Ferreira-Santos, 2015, p. 202).

O julgamento de certo e errado me impedia a entrega completa. O medo de não fazer corretamente, de dar a resposta errada, medo de me machucar, medo de ser agredida. Vivia um corpo domesticado, vigiado e punido.

A capoeira trouxe a roda. A roda onde todos podem participar. A capoeira trouxe a ginga, o molejo, o ir e vir que, assim como a vida, precisa estar atento e em movimento. A capoeira trouxe o tambor, a musicalidade, a dança, o ritmo, o compasso, o canto, a história, as estórias, os negros, a vivacidade, a força, a resistência, o encantamento, a persistência. A capoeira me trouxe para os pés da "grande árvore" onde se deu o encontro do Mestre Preto de Luz e Alice.

Ferreira-Santos (2015) traduz esta experiência no sentido da construção de uma nova visão sobre o mundo, de 
desconstrução do estar na vida no modelo cartesiano-ocidentalbranco, para uma forma mais sincrética e de maior comunhão com o sagrado feminino. Afirma o autor:

"Esta concepção corporal da música, do canto e da dança de descendência africana contém em si uma cosmovisão comunalnaturalista que chamamos de 'matrial', pois se define por uma sensibilidade feminina em suas expressões maternal, sábia, amante, companheira e filial, no ciclo e drama vegetal das árvores e sementes (talvez seu mais antigo arquétipo), que ainda exibe sua preponderância nos detalhes de nosso cotidiano vivido mais banal, apesar do domínio patriarcal na superfície do substrato social, político e econômico da sociedade que intenta suprimi-la de todas as formas (pois que é uma ameaça ao seu poder instituído), inclusive das maneiras mais violentas sobre o próprio corpo feminino." (Ferreira-Santos, 2015, p. 201)

Foi o pulsar do tambor, o toque do berimbau, o ritmo do agogô, a quebrada do pandeiro, o bater de palmas, os corpos que juntos compunham um movimento dialético, sincronizado, composto em sua essência que me trouxeram de volta à raiz, à mãe-terra. A capoeira entrou em minha vida como um cordel de fogo. Incendiou tudo e não teve alma dentro de mim que não tivesse sido aquecida por essa chama. A capoeira me levou de volta para casa. Reconheci ali toda a minha ancestralidade, me reconheci.

Essa capoeira a qual me refiro foi toda cantada por Mestre Alcides. Ele, homem negro, subversivo em sua sobrevivência no mundo dos brancos. Ele, velho negro de história e estórias de vida. Ele, homem velho negro e cheio de luz, trouxe para minha vida a possibilidade de recomeçar. Um encontro iniciático do tipo "maiêutico", que "ajuda o sujeito a se exteriorizar e se realizar em sua própria busca, a dar à luz em um segundo nascimento". (Ferreira-Santos,2010a , p. 233) 
Mestre Alcides não andava só, um bando o acompanhava. No Ceaca aprendemos que somos irmãos. Grupo de capoeira não é só um grupo que se reúne para um determinado fim, há um sentido de família, de irmandade, de coletivo, de comunidade. Uma vez que se faz parte do grupo, um lugar seu sempre estará ali, mesmo que você parta. Sempre estarão a sua espera, sempre o receberão de volta. Esse sentido de unidade, segundo FerreiraSantos, se dá em qualquer manifestação de cultura popular de origem afrodescendente, basta que se preste atenção e esta raiz ancestral, logo será notada e sentida. (Ferreira-Santos, 2010a, p. 203)

Com Mestre Alcides e a capoeira, reaprendi a ouvir. A lembrança sobre sentar e ouvir para aprender, eu só tenho da pré-escola. Foi o único lugar onde me ensinaram que é com estórias que aprendemos. Também lembro de sentar para ouvir as histórias da roça da minha avó. De sentar para ouvir as mulheres da família na cozinha conversando. Quando era criança, eu não podia falar naquela roda, era tempo de ouvir. E tanta coisa se aprendia nessas conversas da mesa cozinha. Um reconectar-se pela palavra, este

$$
\begin{aligned}
& \text { “(...) dedo-de-prosa ... num 'causo' a ser contado na soleira da } \\
& \text { porta atrás da fumaça de um velho cachimbo a materializar os } \\
& \text { espíritos ancestrais. A espantar o "banzo". A idiotice que resulta } \\
& \text { da saudade mais profunda e incurável. Aquilo que os gregos } \\
& \text { chamavam de "póthos nós, de língua luso-brasileira, chamamos, } \\
& \text { simplesmente, de 'saudade'. (Ferreira-Santos, 2015, p.202 ) }
\end{aligned}
$$

São esses rituais de infância, esses rituais de família, esses rituais de estar junto que a capoeira trouxe de volta para minha vida. Uma vida que andava tão só, tão desconectada das coisas da alma, tão surda para as palavras que correm com o vento, tão 
dura e enrijecida como um tronco velho de madeira seco caído no chão.

Estar na capoeira abriu portas e janelas e passei a andar com as pessoas da cultura tradicional de São Paulo. Passei a ter uma rede social que ia além de colegas da USP ou do trabalho. Minha solidão havia acabado. Estar nesses lugares também me proporcionou viver o lado preto da vida e digo isso no sentido mais bonito e mais carregado de história que possa significar. Passei a viver no mundo dos pretos e me dar conta do apartheid em que vivemos. Passei a me dar conta de que os muros da escravidão ainda estavam de pé, que brancos ainda abusam de pretos e que vivemos num mundo absolutamente racista.

Esse contato me levou de volta às minhas raízes e me dei conta de que na infância foi esse o meu mundo. Eu cresci na senzala e fui tirada dela quando minha mãe decidiu tentar levar uma vida classe média. A vida de operário, do samba, da periferia, dos "botecos" foi embora de mim quando minha mãe casou. E lembro que sair desse mundo foi penoso. Estar de volta às minhas origens me fez ver que eu tinha alma preta e que aquela luta também era minha. Minha ancestralidade me havia sido arrancada junto com a minha identidade primeira. Assim como os pretos que negam sua ancestralidade pelo racismo, eu passei a negar minha identidade cultural também pelo racismo. A ancestralidade por mim sentida e vivida é colocada por Ferreira-Santos da seguinte forma:

"Ancestralidade aqui entendida como um traço constitutivo do meu processo identitário herdado e que vai além da minha própria existência. Esta afirmação em primeira pessoa reafirma o caráter pessoal da relação com os traços herdados, que somam aos outros elementos do processo identitário. Assim, não se considera a identidade como um bloco homogêneo e imutável, 
mas um processo aberto e em permanente construção, no qual dialogam diversos fatores determinantes, escolhidos ou não, em contraste com a alteridade com que nos relacionamos. O outro lado ancestral como herança, que pode ser também biológica (mas não necessariamente), é muito mais extensa e mais durável (referindo-se ao tempo histórico) que minha existência pessoal (o limitado tempo da minha existência). Esta é a herança coletiva do grupo comunitário ao qual pertenço e me transcende. Visto assim, temos com a ancestralidade, uma dívida à medida em que somos o futuro que se imaginava no passado e nos compete manter vigentes suas energias mobilizadoras e fundantes. Em resumo: nossa dívida com a ancestralidade é que temos que ser nós mesmos" (Ferreira-Santos, 2015, p. 231)

\section{Alice abriu mão de tudo para essa nova vida. Abri mão de tudo que até então havia conquistado, para ir ao encontro de mim mesma.}




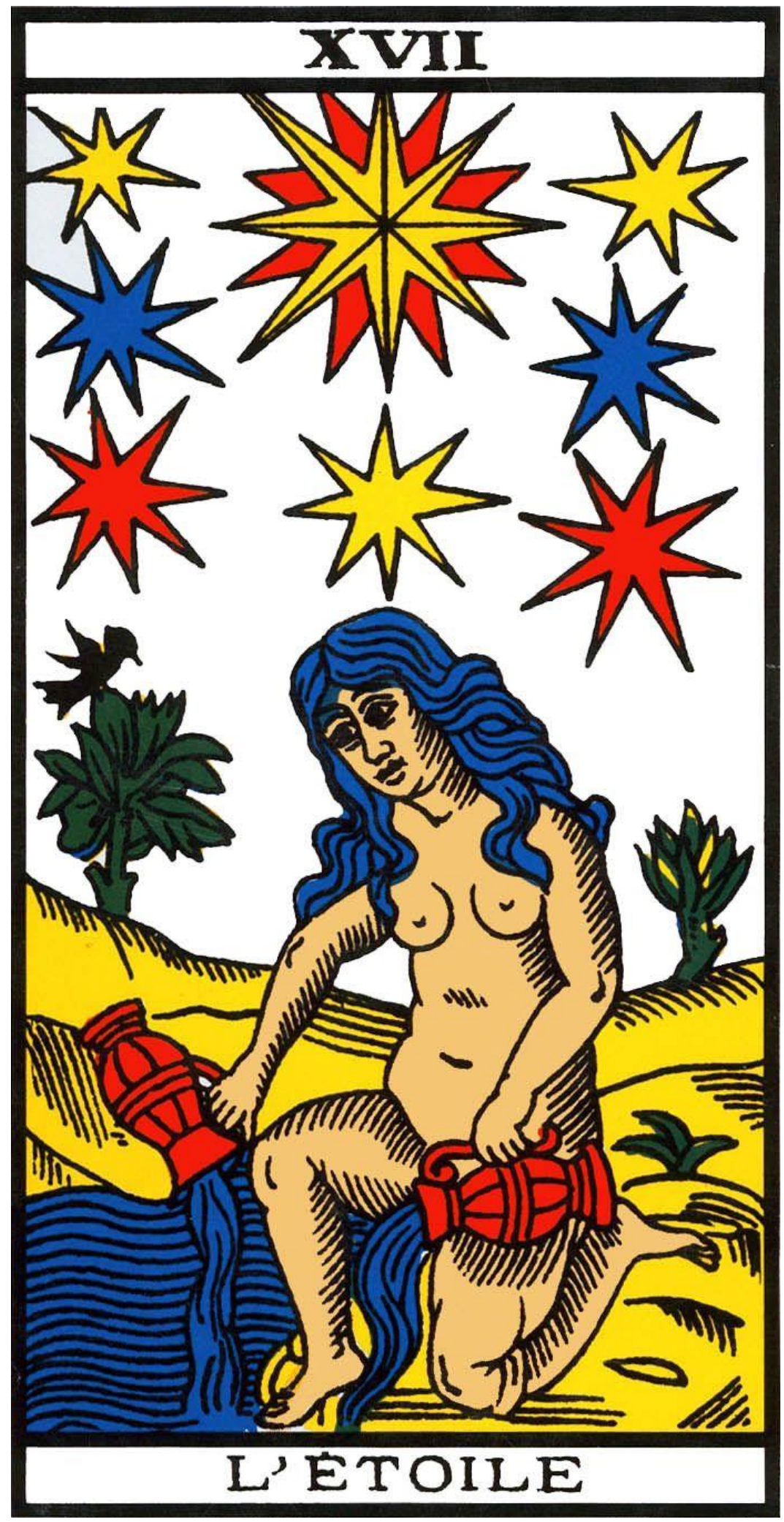




\section{7 - Alice e os guerreiros de Aruanda}

Alice havia se dedicado e se empenhado muito, mas ainda não era uma guerreira. O velho preto havia dito a ela que havia outros velhos pretos vivos escondidos em cantos que ninguém podia ver. Só aqueles que se preparavam para a guerra é que obtinham poderes mágicos de enxergar o invisível no mundo.

Alice deixou Presente com o bando e saiu sozinha em busca de outros velhos pretos que pudessem ensinar a ela um pouco mais da arte de lutar. Esta luta não era como as outras, não era com faca ou facão, não era de armas de fogo, não era de bombas ou destruição. Era a luta dos que não são vistos, da agilidade, da força, da magia deixada pelos que já se foram.

Alice quase já andava só. Castigo havia morrido e Presente já era um menino-homem. Alice partiu. Andou muito, nadou, correu... descansou e seguiu viagem. Chegou a uma terra sagrada e muito antiga, de muitas lendas, muitos seres mágicos. Disseram a ela que esta era a terra roubada e que ali encontraria os velhos pretos e invisíveis que procurava.

No meio de um caminho sem fim, Alice viu uma luz. Uma luz como de um vaga-lume que piscava sem parar. Ela achou que ali poderia encontrar alguma resposta. Ao se aproximar, a luz foi ficando grande e o que parecia ser só um inseto que piscava, era a entrada para o passado, um passado muito distante, onde nem ela mesma existia.

Ali, Alice viu muitos guerreiros. Eles eram fortes, alegres, dispostos e estavam tão bem preparados, que Alice se sentiu fraca e incapaz. Entre os homens havia também mulheres guerreiras, mulheres fortes e de muita luz. 
Todos eles cantavam juntos e dançavam na noite em que Alice chegou. Na manhã seguinte, nem o dia tinha nascido, estavam todos de pé se preparando para a grande batalha. Alice pensou que não tinha condições de ficar, mas disseram a ela que ficasse e que ela também era guerreira e poderia ajudar.

Um dos guerreiros pediu a Alice que o acompanhasse, ele seguiria só pela floresta e precisaria de ajuda para abrir caminhos e formar um novo bando. Alice viu neste guerreiro toda a força que sempre desejou ter, viu em seus olhos um brilho de viver e em seus pés, o chão que Alice nunca teve.

Alice seguiu com o guerreiro em busca de também se tornar uma guerreira. Com eles, levaram um pequeno menino de luz de nome Desejo. Este menino era o farol que iluminava quando a luz falhava e ambos ficavam invisíveis, sem conseguir ver nada, nem ninguém.

Alice levou Presente para guerrear também, mas esperava ainda que ele se fortalecesse e se transformasse num homem guerreiro. O bando era grande e eles seguiam a treinar, a cantar, a ficar forte e poder lutar pelos velhos pretos. Alice era agora um bruxa-guerreira. 


\section{1 - O início do fim - a trajetória final deste caminhar}

Em outubro de 2013, iniciava-se uma nova fase de capoeira na minha vida. Um novo professor havia sido admitido no Cepeusp - Centro de Práticas Esportivas - USP - e seu curso teve início no meio do semestre. Assim, por curiosidade, cheguei na capoeira angola (Araújo, 2004; Gomes, 2012; Vale, 2012) com o professor Womually. Apesar de ouvir falar de capoeira angola, nunca tinha visto de perto, estado em grupo ou com um capoeirista "angoleiro". Mais uma descoberta - a capoeira que tocava meu coração era esta. Era esta a capoeira que eu queria aprender a jogar.

No mesmo mês, recebi um convite para um evento de capoeira angola em Salvador, BA. Em meio a muitas dúvidas sobre ir ou não, acabei comprando a passagem na véspera do evento e embarquei para umas das experiências mais profundas da minha vida.

Cheguei em Salvador numa terça-feira ensolarada. Uma mala nas costas e muita vontade de aprender. Eu era (sou) iniciante na arte da capoeira e da capoeira angola eu era apenas

uma curiosa. O evento foi na Associação de Capoeira Angola Navio Negreiro - Acanne, sob os cuidados do mestre Rene Bittencurt. Quando cheguei fiquei um pouco insegura. Quase todos os participantes eram do grupo e vinham de muitos lugares do Brasil e do mundo. Na verdade, no dia em que cheguei, só havia mais um participante de outro grupo, seu nome era Pedro e foi com ele que vivi a maior das aventuras.

No evento, me dispus a ser eu mesma. Algo me dizia internamente que não era hora de inventar personagem ou levar para o grupo aquela “Carla da USP”. Ouvi de mim mesma: "Seja 
você, não importa que coisas na vida te fizeram usar máscaras, aqui você deve ser quem você realmente é!" Há muito tempo que havia decidido ser outra pessoa, alguém que pudesse me proteger do mundo ou das situações ruins em que me envolvia. Lá na Acanne, me despi das cascas e tentei ser a Carla que eu era em tempos passados.

Os treinos eram incríveis, pela primeira vez na vida tive aula com uma mulher, a Catarina. Eu nunca tinha visto mulher tão empoderada (Oliveira, 2008) no espaço da capoeira. Conheci muitos mestres e em especial, o mestre Rene. Ele, que conduz seu navio negreiro, chamando para o encontro almas que conviveram num mesmo quilombo num tempo passado, como ele diz.

Foram momentos de muita magia, muito ricos e de grande conexão com saberes ancestrais. O nome do evento era "Sabor do saber ancestral". Fui me nutrir da sabedoria carregada na alma desses velhos de luz.

Pedro, o rapaz que citei anteriormente, j'a no primeiro dia, foi um companheiro. Fomos nos aproximando e, o fato de sermos de São Paulo, acabou nos unindo em conversas, longos diálogos sobre a vida, o passado, o presente, os amores. Pedro tinha muita coisa em comum comigo. Durante a semana que passamos na Acanne, cada dia era uma nova descoberta sobre nossas semelhanças. Nós dois tínhamos um filho de nome João Pedro, os dois de São Paulo, os dois fizeram faculdade de Biologia (ele não concluiu), ele era só um ano mais velho do que eu, então havia muitas referências em comum sobre a adolescência e infância. Havíamos gostado das mesmas coisas, ouvimos as mesmas músicas e, os mundos que nunca se 
encontraram, haviam se cruzado muitas vezes. Ele fazia aniversário no dia nove de outubro e eu sou do dia oito. Também havia os relacionamentos, falávamos sobre o passado como se ele tivesse sido vivido junto. Era muita sincronicidade.

A cada dia que passava, mais próximos ficávamos. Ele era casado e eu respeitava muito este fato. Assim, apesar de ter olhos que brilhavam para aquele homem, nunca deixei transparecer nada. Descobri um amigo com muita coisa em comum, um amigo que tive vontade de levar para a vida. Meu sentimento por Pedro foi tão intenso, que na sua partida fiquei desorientada. Não sabia o que fazer naquele lugar sem ele.

O retorno para São Paulo foi difícil. Cheguei num domingo nublado e chuvoso, assim como me sentia. No ônibus de volta para casa, eu chorei. Nada fazia sentido. Aquela cidade sem fim, cinza e cheia de concreto. Meu dia a dia atolado de trabalho, minha vida cheia só de datas e contas para pagar. Eu não queria mais aquela situação... Queria mar, queria praia, queria capoeira, queria nada para pensar, queria gente para conversar, queria festa, queria prazer.

Os dias foram passando e eu me reorganizando, voltando aos poucos para o meu papel. Passada a semana, comecei a sentir uma grande saudade de Pedro. Ele não era um homem acessível, pouco usava a internet e eu não podia me declarar em todo meu sentimento. Mais uma semana se passou e ele entrou em contato. Ele morava em Minas Gerais com sua família, em um sítio onde era produtor de orgânicos. Viria a São Paulo visitar sua mãe e me convidou para sair.

No dia em que ele chegou, me ligou e eu o convidei para ir me visitar. Em sua visita, tomei cuidado para não deixar 
transbordar a paixão que já sentia. Durante a conversa, ele me disse que estava se separando. Que algo havia mudado por conta do nosso encontro e que seu retorno para a vida que tinha já não fazia sentido. Meus olhos brilharam como nunca antes e me declarei. Nesse dia Pedro ficou em minha casa e para lá se mudou.

Era dezembro e logo eu estaria em férias. Pedro foi ficando e junto com ele vieram as consequências da vida que ele largava em Minas Gerais. Pedro vivia o fim de um relacionamento desgastado que já se arrastava há anos. Sua exmulher era uma mineira, de origem humilde e diferente culturalmente do que Pedro se apresentara para mim.

Alguns dias antes do Natal, Pedro retornou para Minas Gerais para organizar a casa onde morava e receber os filhos para as festas de final de ano. Pedro me ligou pedindo ajuda. Comovida com a situação, resolvi ir ajudá-lo. Na verdade, não tomamos cuidado com as crianças. No desejo de ficarmos juntos o mais rápido possível, atropelamos tudo e todos que estavam no caminho. Em menos de duas semanas, nossos três filhos já tinham que conviver com a ideia de vidas desfeitas e refeitas. Foi muito duro para todos.

Quando cheguei ao sítio, fiquei assustada com o lugar que encontrei. Era uma casa grande com as paredes pintadas com cores fortes e coloridas. Cada cômodo era de uma cor e a sala era de um verde bem escuro. A casa estava vazia e suja, muito suja. Nas paredes havia muitas fotos e atrás de cada quadrinho, muitos insetos mortos. A casa parecia um grande insetário. Nunca tinha visto tanto abandono num lugar onde morava gente. Fui limpando, jogando fora, mexendo nas coisas. Era muita 
história para se livrar, era muita lembrança perdida pendurada pelas paredes, era um caos em forma de vida.

Organizar tudo aquilo me fez sentir importante, mas ao mesmo tempo me assustava. Aquele lugar não se encaixava nas fantasias que eu havia construído sobre a vida de Pedro, mas diante de toda situação e da minha paixão, não tinha como recuar. Eu estava mergulhada nessa história que não me pertencia.

Pedro se mostrou sempre muito apaixonado e falávamos em casar, e ele, em ter um filho comigo. Eu tinha muita vontade de ter mais um filho, mas tinha medo de nada dar certo e eu sofrer mais uma vez uma desilusão.

No primeiro semestre de 2014, começaram as crises. Pedro havia passado dez anos de sua vida na roça, numa cidade pequena e inserido na cultura local. Havia absorvido hábitos muito ruins para quem é da cidade grande. Isso atrapalhou muito o início da relação porque eu que vinha de tantas andanças e era tão comprometida comigo e meu filho que não me encaixava neste perfil de homem.

Mas minha paixão por ele não me deixava abandonar o relacionamento. Apesar das dificuldades, nos completávamos. Nós nos fazíamos companhia, conversávamos, sonhávamos, nos amávamos. Pedro me mostrou e me fez sentir um amor maior que todos, maior e mais intenso do que qualquer coisa que eu já tinha vivido até então.

Mas havia os pesares que eram bem pesados. Um dia, fui com ele para Minas Gerais e vi Pedro na terra. Ele se transformava, ficava maior, mais forte, mais seguro, mais homem. Achei que a solução para nossos problemas seria nos 
mudarmos para o sítio e recomeçarmos uma nova vida. Construiríamos um projeto de permacultura, juntando tudo o que sabíamos, mais o que queríamos, mais o que já havíamos vivido, tudo numa história só.

É preciso dizer que, quando esta ideia nasceu, eu já gestava um filho. Engravidei de Pedro em abril e seria mãe pela segunda vez.

A minha vida estava um caos. Eu não queria mais trabalhar em lugar nenhum e não conseguia avançar nas investigações da tese, só conseguia viver meu relacionamento com Pedro.

Em julho, organizamos a mudança. Em meio a enjoos e planos mirabolantes, encaixotamos minhas coisas. O caminhão se foi e ficamos na pequena casa vazia, pintando e vivendo nossos últimos dias na cidade-concreto. $\mathrm{Na}$ minha imaginação, partíamos para o castelo encantado para viver história de príncipe e princesa.

Quando chegamos a Cruzília, MG, mais uma vez encontrei o caos. Precisamos pintar a casa e colocar no lugar cada móvel, cada detalhe, cada sonho, cada plano, cada projeto. Não transcorreu um mês e eu estava com depressão. Odiava morar ali.

Em agosto precisei entregar meu relatório de qualificação e não tinha forças para escrever. Não trabalhava em nada da tese há meses, minha vida estava uma bagunça e eu estava triste, muito triste. Pensei em desistir, em não escrever, em abandonar o doutorado. Pedro não deixou. Tentou me fazer ver que largar o doutorado me faria mal, que nunca me perdoaria por isso e eu fui escrever. Escrever sobre minha vida naquele momento era 
penoso demais. Era como se eu tivesse que olhar para tudo que conquistei e larguei para estar ali.

Eu e Pedro tentávamos um relacionamento feliz, mas havia muitos ajustes a serem feitos. Brigávamos demais, mas também nos dávamos muito bem. Acho que nosso relacionamento sempre foi, desde o início, muito intenso; intenso como nós somos. Eu e Pedro vivemos tudo à flor da pele, o que é bom e ruim, em seus extremos.

Depender do Pedro para tudo também era algo assustador para mim. Dependia dele até para sair do sítio, que era afastado da cidade e não havia nenhum meio de locomoção que não fosse carro. Eu, grávida, atordoada por não lidar bem com meu estado e dependia dele até para me locomover.

Foram muitos os dias em que eu não saí do quarto, em que não via motivos para levantar da cama, em que eu só chorava lamentando e lamentando. Os dias seguiam secos... Passamos pela maior seca da década. Pedro levantava muito cedo para cuidar da produção de abóboras e trabalhava como um escravo. Andava de um lado para o outro carregando água no balde, para conseguir irrigar lugares em que água nenhuma chegava.

Toda esta disposição também me afetava. Via nele uma energia que eu queria ter, que eu precisava para mudar algo e retomar minha vida, porém eu não conseguia... não conseguia me mexer. Estava triste com tudo, até com o fato de estar triste. Foi, sem dúvida, o momento mais difícil da minha vida. Dezembro ia chegando e eu não me animava. Nosso filho ia nascer e eu ia ficando cada vez mais desesperada por me ver em situação tão deprimente. Como poderia me entregar a um bebê? 
Como poderia cuidar de um serzinho tão pequeno, que exigiria tanto, se eu não tinha forças nem para me levantar?

No dia 26 de dezembro, Jahmall nasceu. Na nossa hora, não deu tempo de formar equipe médica, não deu tempo da equipe se preparar... não deu tempo de nada. Na terceira contração, dentro da sala de parto, Jahmall nasceu. Nasceu da barriga, da força, da vontade... Foi quase um milagre de parto... Em quinze minutos, Jahmall estava nos meus braços e nos olhávamos tentando nos reconhecer como mãe e filho. Jahmall era meu desejo pela vida renascendo em mim.

Em janeiro, estávamos com uma nova família. Eu nascendo como mãe de um bebê que sofria comigo a minha dor. Ele chorava muito, muito mesmo. Já havíamos combinado que Pedro não trabalharia mais, porque a renda da produção não era suficiente para nos sustentar e, daquele momento em diante, começamos a planejar nosso retorno para São Paulo ou para qualquer outro lugar, onde eu pudesse voltar à vida.

Nessa época, em maio de 2015, nós já havíamos estabelecido uma rotina de passar um final de semana em São Paulo a cada quinze dias. Isso me desafogava o coração. Em junho, encontramos uma casa no bairro do Butantã e, mais uma vez, fomos viver de fantasia. Acreditávamos que, muito rapidamente, eu estaria empregada, que Jahmall ficaria melhor, que eu passaria a dormir, que eu voltaria a treinar e trabalhar. Tínhamos a preocupação de Pedro não conseguir se recolocar profissionalmente, mas a ideia de estar perto do seu grupo de capoeira, valia para ele qualquer esforço.

Claro, que não foi nada disso. Os meses passaram e mudar para São Paulo acabou mudando pouco minha dinâmica. 
Continuava presa em casa porque o tempo estava sempre (ou quase sempre) chuvoso e porque Jahmall vivia doente. Pedro saía para a capoeira e pouco conseguia se envolver nos cuidados com nosso filho. Eu continuava sem conseguir trabalhar, treinar, sair, viver...

Decidimos colocar Jahmall na creche. Passei a ter algum tempo para mim, que eu usava para o que quisesse, mas acabava ficando sempre na situação da casa. Em agosto, decidi oferecer um núcleo de vivência e experimentação de "varal de memórias" no Lab_Arte, nos moldes de sua estrutura e a partir de minhas experiências anteriores, e fazer uma disciplina de pósgraduação para tentar retomar meu contato com a universidade.

Os meses de agosto e setembro foram me dando aquele gostinho de vida, de um pouco de liberdade, de retomada. Eu estava mais feliz, mas ainda muito triste e paralisada. Voltar para a USP me deu forças e minhas atividades ali me ajudavam a criar estímulos para seguir.

Em novembro, Pedro conseguiu emprego. Apesar de ser ótimo, senti uma inveja sem tamanho. Senti muita inveja por ele estar bem, bonito, feliz, trabalhando e eu naquela situação: dependente, infeliz, angustiada e amarga. No mesmo mês, mandei muitos currículos para muitos lugares. Fui chamada para algumas entrevistas, mas assim como à época da seleção para o mestrado, parecia que eu dizia algo muito errado e não fui chamada em lugar nenhum. Ouvi que eu tinha filho muito pequeno para voltar a trabalhar, que meu currículo era muito bom, que eu tinha uma vida muito instável... Ouvi absurdos atrás de absurdos e apesar de toda dor, fui me conformando com a possibilidade de ficar desempregada mais algum tempo. 
A experiência com as oficinas do Lab-Arte no núcleo "Varal de Memórias" foi incrível, me deu força de continuar e comecei a fazer planos para 2016. Uma equipe gestora de uma pequena escola em Osasco me contratou e eu voltaria para a sala de aula no ano seguinte.

No início de 2016, eu e Pedro estávamos cada vez mais afastados. Tentávamos nos reorganizar, mas não conseguíamos. A cada briga um distanciamento maior, que no reencontro, se transformava sempre em uma grande promessa de dias mais felizes. Vivemos um relacionamento "bipolar". Em março nos separamos. Foi a dor emocional mais intensa que sofri na vida.

Passei dois meses sem conseguir me alimentar direito. Dentro de mim só havia angústia e tristeza. Passei por um verdadeiro luto. No final de abril tentamos nos reaproximar. Ele não voltou para casa, mas nos visitava semanalmente. Em suas visitas, ficávamos juntos, sonhávamos com um futuro mais feliz. Em junho, em meio a planos mirabolantes, juras de amor e tentativas frustradas de reencontro... Pedro se foi para não voltar mais.

Não houve conversa final, nem explicações, nem acordos e nem despedida. Pedro simplesmente se foi.

Transformei toda a dor deste triste fim de relacionamento no impulso para terminar as investigações desta tese que foi finalizada no luto da separação. 


\section{2 - O reencontro com a alma - a busca pela ancestralidade perdida}

Este conto de Alice traz a minha trajetória final ao concluir esta tese e da vida que se constituiu até o momento. $\mathrm{O}$ contato com a capoeira e a busca pela ancestralidade perdida me fizeram andar por novos caminhos em busca de mais respostas. Minha alma ainda estava faminta. Apesar de ter propiciado a ela um momento de respiro, ainda era uma alma carente de atenção. As máscaras que havia inventado para sobreviver no mundo acadêmico empobreciam meu mundo interior e a capoeira veio apenas abrir as comportas desta água que estava represada em $\operatorname{mim}$.

Mestre Alcides trouxe a capoeira e o convite para o resgate da ancestralidade negra perdida. Aceitei o convite e parti para novas descobertas, que incluíam não só a busca por uma nova vida pessoal e interior, mas a também a busca por me encontrar enquanto pesquisadora em uma nova área. Sob orientação do Prof. Marcos Ferreira-Santos, fui apresentada a uma nova área de estudos, a mitohermenêutica. Não tinha nenhuma ideia sobre o que tratava o assunto. As primeiras indicações de leitura foram para mim um grande desafio. Era uma forma absolutamente nova de escrita e visão de mundo. $\mathrm{Eu}$, finalmente, havia encontrado uma linha de estudos que dialogava intensamente com as minhas questões interiores. Era muito mais complexo do que as questões que traziam a Educação Ambiental, apesar de haver ressonâncias entre as ideias. Fazia muito mais sentido do que as teorias que estudei durante o mestrado. 
Foi uma fase de buscar por novos caminhos em todas as instâncias da vida. A linha de pesquisa à qual pertencia agora, se ligava diretamente às novas buscas pessoais: a capoeira, a ancestralidade africana, a oralidade como forma de aprender e ensinar, a relação mestre-aprendiz, a formação da pessoa e sua história de vida. Consegui relacionar a pesquisa às questões da alma. Agora, tudo seguia um caminho comum. Ferreira-Santos (2010) ao tratar da questão da ancestralidade afro-ameríndia como constituição de uma nova linha de pensar e fazer ciência, complementa que:

“Não há esforço, sem engajamento epistemológico ou cognitivo
que dispense a relação amorosa com o pseudo-objeto da relação
'eu- o outro- o mundo'. Muito antes de conhecer algo, ama-se
esse 'algo' e, por essa razão, a participação mística é o ponto de
relação epistêmica e não o seu ponto de chegada e de partida. É o
privilégio de empatia e simpatia como convergência de pathos”.
(Ferreira-Santos, 2010, p. 234)

Este processo é representado no conto e Alice como a busca de Alice por outros velhos pretos de luz. O seu mestre a prepara para esta nova jornada, ele é a ponte, a comunicação entre os mundos que Alice deverá percorrer. Ele aponta o caminho, mas Alice deve seguir só. Esta é uma busca pessoal, de encontrar-se em suas novas descobertas. No trecho: "Alice partiu. Andou muito, nadou, correu... descansou e seguiu viagem. Chegou numa terra sagrada e muito antiga, de muitas lendas, muitos seres mágicos. Disseram a ela que esta era a terra roubada e que ali, encontraria os velhos pretos e invisíveis que procurava”, a representação do meu encontro com a ancestralidade africana perdida, o mundo que, de fato, se descortinava aos meus olhos.

"A ancestralidade nos abre e nos apresenta possibilidades de religação com nosso tecido social originário: nos religa aos 
nossos. Desta religação, possibilitada pela vivência limítrofe, temos uma outra maneira de ver o próprio mundo e a nós próprios numa releitura das coisas, relegere, em que transformamos o nosso olhar, as nossas atitudes e nossas relações" (Ferreira-Santos, 2005a, p. 213-214).

Alice se encontra com guerreiros, guerreiros estes que dialogam diretamente com os "aspectos guerreiros nas mitologias africanas" de que trata Ferreira-Santos (2005b, p. 136).

"Uma das mais frequentes na memória negra e das mais solicitadas por aqueles que brandem no front das lutas sociais, empunhando suas lanças legais (projetos de lei, cotas sociais, reparação financeira de dívida, penas mais graves por descriminação racial, etc.), sem dúvida, é a imagem do guerreiro. Altivo, forte e destemido, o guerreiro negro joga energia, oferecendo a própria vida pelo que se empenha (...) O guerreiro funda o poder patriarcal”.

Em Alice, o encontro com esses guerreiros se dá em um passado perdido, um passado na qual nem ela mesma existia - a cultura ancestral que permanece na alma e imortal, sobrevive entre gerações que convalescem da opressão em manifestá-las. Mas que está ali, viva, em canto, em dança, em deuses, em mitos e nas relações entre os mestres e aprendizes que carregam a ancestralidade nas expressões culturais, como a capoeira.

Alice encontra no bando, um guerreiro que a escolhe como companheira e a convida para formar um novo bando. Esta formação se daria numa floresta onde o guerreiro abriria novos caminhos. Este adentrar pela floresta, representa mais uma descida ao inconsciente em busca do self. Este encontro, promoverá a batalha final, onde Alice deverá utilizar todo o conhecimento adquirido com seus mestres para sobreviver. Em vida, este encontro propiciou a descida ao mais profundo de mim. 


\section{3 - Alice e o guerreiro - o encontro para o caminho do self perdido}

O guerreiro de que trata o conto de Alice representa Pedro na autobiografia. Esse encontro promoveu a descida para o mais profundo de mim, o reencontro, o rever-se, o reconectar-se. Na autobiografia relatei esse encontro e as mudanças que trouxeram para a minha vida. Foi um momento de magia, onde me vi completamente entregue, sem armas, sem mascaras, fui em alma amar este homem. Aqui, farei uma paralelo com o mito de Narciso e o conto "Os sapatinhos vermelhos", analisado por Estés (1999, p.160) quando trata sobre "A preservação do self: A identificação de armadilhas, arapucas e iscas envenenadas”.

Sobre o encontro com o guerreiro, é dito em Alice: "Alice viu neste guerreiro toda a força que sempre desejou ter, viu em seus olhos um brilho de viver e em seus pés, o chão que Alice nunca teve", uma busca pelo complementar, pelo que Alice não tinha e desejava ter. No entanto, na autobiografia, o que se pode ver, foi que esse foi um encontro entre pares iguais. Minha aproximação com Pedro se deu exatamente pelas semelhanças. Eram muitas as coincidências de vida, fato que foi criando em mim uma fantasia sobre um "par perfeito". Para uma alma faminta, um "prato cheio".

Estés (1999) usa o conto "Os sapatinhos vermelhos" para narrar a situação da mulher que com a alma faminta, encontra o objeto do seu desejo. Este é o único conto que utilizarei na íntegra nesta tese.

"Era uma vez uma pobre órfã que não tinha sapatos. Essa criança guardava os trapos que pudesse encontrar e, com o 
tempo, conseguiu costurar um par de sapatos vermelhos. Eles eram grosseiros, mas ela os adorava. Eles faziam com que ela se sentisse rica, apesar de ela passar seus dias procurando alimento nos bosques espinhosos até muito depois de escurecer.

Um dia, porém, quando ela vinha caminhando com dificuldade pela estrada, maltrapilha e com seus sapatos vermelhos, uma carruagem dourada parou ao seu lado. Dentro dela, havia uma senhora de idade que lhe disse que ia levá-la para casa e tratá-la como se fosse sua própria filhinha. E assim lá foram elas para a casa da rica senhora, e o cabelo da menina foi lavado e penteado. Deram-lhe roupas de baixo de um branco puríssimo, um belo vestido de lã, meias brancas e reluzentes sapatos pretos. Quando a menina perguntou pelas roupas velhas, e em especial pelos sapatos vermelhos, a senhora disse que as roupas estavam tão imundas e os sapatos eram tão ridículos que ela os jogara no fogo, onde se reduziram a cinzas.

A menina ficou muito triste, pois, mesmo com toda a fortuna que a cercava, os modestos sapatos vermelhos feitos por suas próprias mãos haviam lhe dado uma felicidade imensa. Agora, ela era obrigada a ficar sentada quieta o tempo todo, a caminhar sem saltitar e a não falar a não ser que falassem com ela, mas uma chama secreta começou a arder no seu coração e ela continuou a suspirar pelos seus velhos sapatos vermelhos mais do que por qualquer outra coisa.

Como a menina tinha idade suficiente para ser crismada no dia do sacramento, a senhora levou-a a um velho sapateiro aleijado para que ele fizesse um par de sapatos especiais para a ocasião. Na vitrina do sapateiro havia um par de lindíssimos sapatos vermelhos do melhor couro. Eles praticamente refulgiam. Pois, apesar de sapatos vermelhos serem escandalosos para se ir à igreja, a menina, que só sabia decidir com seu coração faminto, escolheu os sapatos vermelhos. A vista da velha senhora era tão fraca que ela, sem perceber a cor dos sapatos, pagou por eles. O velho sapateiro piscou para a menina e embrulhou os sapatos.

No dia seguinte, os membros da congregação ficaram alvoroçados com os sapatos da menina. Os sapatos vermelhos brilhavam como maçãs polidas, como corações, como ameixas tingidas de vermelho. Todos olhavam carrancudos. Até os ícones na parede, até as estátuas não tiravam os olhos reprovadores dos sapatos. A menina, no entanto, gostava cada vez mais deles. Por isso, quando o bispo começou a salmodiar, o coro a cantarolar, o órgão a soar, a menina não achou que nada disso fosse mais belo que os seus sapatos vermelhos.

Antes do final do dia, a velha senhora já estava informada dos sapatos vermelhos da sua protegida.

- Nunca, nunca mais use esses sapatos vermelhos! - ameaçou a velha. No domingo seguinte, porém, a menina não conseguiu deixar de preferir os sapatos vermelhos aos pretos, e ela e a velha senhora caminharam até a igreja como de costume. 
À porta do templo estava um velho soldado com o braço numa tipoia. Ele usava uma jaqueta curta e tinha a barba ruiva. Ele fez uma mesura e pediu permissão para tirar o pó dos sapatos da menina. Ela estendeu o pé, e ele tamborilou na sola dos sapatos uma musiquinha compassada que lhe deu cócegas nas solas dos pés.

- Lembre-se de ficar para o baile - disse ele, sorrindo e piscando um olho para ela.

Mais uma vez, todos lançaram olhares reprovadores para os sapatos vermelhos da menina. Ela, no entanto, adorava tanto esses sapatos que brilhavam como o carmim, como framboesas, como romãs, que não conseguia pensar em mais nada, que mal prestou atenção no culto. Estava tão ocupada virando os pés para lá e para cá para admirar os sapatos que se esqueceu de cantar.

- Que belas sapatilhas! - exclamou o soldado ferido quando ela e a velha senhora saíam da igreja. Essas palavras fizeram a menina dar alguns rodopios ali mesmo. No entanto, depois que seus pés começaram a se movimentar, eles não queriam mais parar; e ela atravessou dançando os canteiros e dobrou a esquina da igreja até dar a impressão de ter perdido totalmente o controle de si mesma. Ela dançou uma gavota, depois uma csárdás e saiu valsando pelos campos do outro lado da estrada.

O cocheiro da velha senhora saltou do seu banco e correu atrás da menina. Ele a segurou e a trouxe de volta para a carruagem, mas os pés da menina, nos sapatos vermelhos, continuavam a dançar no ar como se ainda estivessem no chão. A velha senhora e o cocheiro começaram a puxar e a forçar, na tentativa de arrancar os sapatos vermelhos dos pés da menina. Foi um horror. Só se viam chapéus caídos e pernas que escoiceavam, mas afinal os pés da menina se acalmaram.

De volta à casa, a velha senhora enfiou os sapatos vermelhos no alto de uma prateleira e avisou a menina para nunca mais calçá-los. No entanto, a menina não conseguia deixar de olhar para eles e ansiar por eles. Para ela, eles eram o que havia de mais lindo no planeta.

Não muito tempo depois, o destino quis que a velha senhora caísse de cama e, assim que os médicos saíram, a menina entrou sorrateira no quarto onde eram guardados os sapatos vermelhos. Ela os contemplou lá no alto da prateleira. Seu olhar tornou-se fixo e provocou nela um desejo tão forte que a menina tirou os sapatos da prateleira e os calçou, na crença de que eles não lhe fariam mal algum. Só que, no instante em que eles tocaram seus calcanhares e seus dedos, ela foi dominada pelo impulso de dançar.

E saiu dançando porta afora e escada abaixo, primeiro uma gavota, depois uma csárdás e em seguida giros arrojados de valsa em rápida sucessão. A menina estava num momento de glória e não percebeu que enfrentava dificuldades até que teve vontade de dançar para a esquerda e os sapatos insistiram em dançar para a direita. Quando ela queria dançar em círculos, os sapatos teimavam em seguir em linha reta. E, como eram os sapatos que 
comandavam a menina, em vez do contrário, eles a fizeram dançar estrada abaixo, atravessar os campos enlameados e penetrar na floresta soturna e sombria.

Ali, encostado numa árvore, estava o velho soldado de barba ruiva, com o braço na tipoia e usando sua jaqueta curta.

- Puxa - disse ele -, que belas sapatilhas!

Apavorada, a menina tentou tirar os sapatos, mas por mais que puxasse, eles continuavam firmes. Ela saltava primeiro num pé, depois no outro, para tentar tirá-los, mas o pé que estava no chão continuava dançando assim mesmo e o outro pé na sua mão também fazia seu papel na dança.

E assim, ela dançava e dançava sem parar. Por sobre os montes mais altos e pelos vales afora, na chuva, na neve e ao sol, ela dançava. Ela dançava na noite mais escura, no amanhecer e continuava dançando também ao escurecer. Só que não era uma dança agradável. Era terrível, e não havia descanso para a menina.

Ela entrou no adro de uma igreja e ali um espírito guardião não quis permitir que ela entrasse.

- Você irá dançar com esses sapatos vermelhos - proclamou o espírito - até que fique como uma alma penada, como um fantasma, até que sua pele pareça suspensa dos ossos, até que não sobre nada de você a não ser entranhas dançando. Você irá dançar de porta em porta por todas as aldeias e baterá três vezes a cada porta. E, quando as pessoas espiarem quem é, verão que é você e temerão que seu destino se abata sobre elas. Dancem, sapatos vermelhos. Vocês devem dançar.

A menina implorou misericórdia mas, antes que pudesse continuar a suplicar, os sapatos vermelhos a levaram embora. Ela dançou por cima das urzes, através dos riachos, por cima de cercas-vivas, sem parar. Ainda dançava quando voltou à sua antiga casa e viu pessoas de luto. A velha senhora que a havia abrigado estava morta. Mesmo assim, ela passou dançando. Dançava porque não podia deixar de dançar. Totalmente exausta e apavorada, ela entrou dançando numa floresta onde morava o carrasco da cidade. E o machado na parede começou a tremer assim que pressentiu que ela se aproximava.

- Por favor! - implorou ela ao carrasco quando passou pela sua porta.

- Por favor, corte fora meus sapatos para me livrar desse destino horrível.

O carrasco cortou fora as tiras dos sapatos vermelhos com o machado, mas os sapatos não se soltaram dos pés da menina. Ela se lamentou, então, dizendo que sua vida não valia mesmo nada e que ele deveria amputar-lhe os pés. Foi o que ele fez. Com isso, os sapatos vermelhos com os pés neles continuaram dançando floresta afora e morro acima até desaparecerem. A menina era, agora, uma pobre aleijada e teve de descobrir um jeito de sobreviver no mundo trabalhando como criada. E nunca mais ansiou por sapatos vermelhos" 
O conto termina como minha autobiografia nesta tese. Uma história de aventuras, com ganhos e perdas, felicidades e tristeza. De repente, o fim triste e inesperado que Estés (1999) apresenta como o fim típico da personagem que não conseguiu concluir sua transformação. Em Alice, não se dá desta forma, porque ela vem ainda em mais uma aventura, onde tem a oportunidade de reaver-se com sua busca, que no capítulo final fica mais explícito. Mas na autobiografia revela essa fase da minha vida.

De alguma forma, vivia feliz com meus "sapatos vermelhos" feitos com minhas próprias mãos. Era a vida que ia se dando e se transformando à medida em eu progredia nas minhas conquistas pessoais, que neste momento, se ligam ao profissional e acadêmico.

"Os sapatinhos feitos à mão são símbolos da sua ascensão de uma existência psíquica insignificante para uma vida emotiva projetada por ela mesma. Seus sapatos representam um passo enorme e literal no sentido da integração da sua engenhosa natureza feminina na rotina do seu dia-a-dia. Não importa que sua vida seja imperfeita. Ela tem sua alegria. Ela irá evoluir.” (Estés, 1999, p. 165).

Porém, vinha da vida com muita fome na alma.

Como dito no conto anterior, tentei me encaixar em fôrmas nas quais não cabia e, no regresso, estava faminta por mais. Foi quando encontrei Pedro. Pedro parecia um príncipe encantado na carruagem de ouro. Ele era tudo que eu sonhava em um homem e mais um pouco. As coincidências da vida, os quereres em comum. Embarquei na carruagem como a menina dos sapatos vermelhos. No entanto, aos poucos fui me vendo infeliz em um relacionamento que estava longe de ser o que eu idealizava. Fui me vendo em uma situação de sacrifício, onde 
teria que dar algo além do saudável para prosseguir. Fui, sem perceber, dando minha própria vida em troca da realização de uma fantasia.

“Os problemas surgem quando há muito sacrifício, mas nenhuma vida brota disso tudo. Nesse caso, o vermelho é a cor da perda de sangue, em vez de ser a cor da vida do sangue. É exatamente isso o que ocorre na história. Perde-se um tipo de vermelho vibrante e amado quando os sapatinhos feitos à mão são queimados. Isso detona na menina um anseio, uma obsessão e, finalmente, uma dependência do outro tipo de vermelho" (Estés, 1999, p. 166)

A fantasia, no entanto, era absolutamente sedutora. Não conseguia aceitar a realidade de que todo aquele conto de fadas era só uma criação da minha imaginação. Que havia muito a ser acertado antes da união, que algo estaria errado num casamento feliz que se desfaz em dias para uma nova união, onde nem os filhos são respeitados. Não consegui colocar os pés no chão e fazer escolhas mais coerentes e sólidas. A ideia do casamento com o "homem perfeito" faria de mim a então sonhada "mulher perfeita”. Mais uma vez o ego falou mais alto e quando me vi sem saídas diante das decisões tomadas, senti por mim um ódio paralisante que me imobilizava, impedindo que eu tomasse qualquer atitude de retorno. "É possível que a vida de uma mulher definhe no fogo do ódio a si mesma, pois os complexos corroem fundo e, pelo menos por algum tempo, conseguem manter a mulher afastada do trabalho ou da vida que realmente importam para ela". (Estés, 1999, p. 171). Assim, foi minha vida em Cruzília. Aos olhos de quem via, parecia a mulher mais feliz do mundo e muitas vezes ouvi isso de amigos e parentes, quando na verdade, estava infeliz e "braba" - o estado em que Estés chama a mulher que

“(...) um dia viveu num estado psíquico natural - ou seja, em perfeito estado mental selvagem - e que depois se tornou cativa 
de alguma reviravolta dos acontecimentos, passando, assim, a ser excessivamente domesticada e amortecida nos seus instintos próprios”. (Estés, 1999, p.160).

$\mathrm{Eu}$, que estava no caminho do regresso e do reencontro, em busca de me reaver, caí em uma armadilha criada por mim mesma. A sedução do caminho mais fácil, do casamento feliz como o do comercial de margarina, a realização da caminhada partilhada com um companheiro que buscava o mesmo que eu, me tirou da minha busca e caí na armadilha como uma criança ingênua. Não existem homens perfeitos, porque não há seres humanos perfeitos. Eu apenas havia idealizado, projetado em Pedro algo que eu gostaria que ele fosse, mas que na verdade, não era.

A aproximação entre nós foi muito rápida e o conhecimento sobre cada um veio na convivência diária. Eu só sabia sobre ele o que ele me contava. Não havia nenhuma referência, nenhum passado vivido junto, nada. Sem que eu percebesse, Pedro foi se tornando cada vez mais o homem dos meus sonhos. O lado sombra também existia e era perverso na mesma proporção da fantasia do príncipe. Lidar com esta dualidade era extremamente conflitante. Ao mesmo tempo que não podia suportar a sombra, não conseguia me imaginar sem aquela luz. $\mathrm{O}$ amor virou droga e logo estava dependente.

"A dependência começa quando a mulher perde sua vida feita à mão e cheia de significado e passa a ter uma fixação em resgatar de qualquer forma qualquer coisa que lembre essa vida. $\mathrm{Na}$ história, a menina insiste em tentar se reunir aos diabólicos sapatos vermelhos, muito embora eles cada vez mais a façam perder o controle. Ela perdeu seu poder de discriminação, sua capacidade de perceber a verdadeira natureza das coisas. Devido à perda da sua vitalidade original, ela se dispõe a aceitar um substituto fatal. Na psicologia analítica, diríamos que ela abdicou do Self." (Estés, 1999, p.187) 
No entanto, esse relacionamento se transformou em uma das experiências mais valiosas da minha vida, trouxe para a luz o mito que me regia. Eu não tinha nenhuma consciência sobre meu modelo de "homem perfeito", pensava em um homem bonito, cabelos compridos, barba, forte, despojado, politizado, culto, com valores alternativos, com forte ligação com a família, mas ainda assim, muito social e querido dos amigos, capoeirista e de família classe média intelectual de São Paulo - este era meu homem perfeito. Pedro se encaixava em quase tudo, mas na verdade, em quase nada. Ele era capoeirista de uma família classe média intelectual da Vila Madalena, o resto foi vindo com o tempo. O tipo físico foi arduamente esculpido em treinos físicos intensos e logo ele estava magro e forte. Os cabelos foram sendo deixados crescer, assim como a barba, que antes eram bem curtos. Ele era machista e o discurso feminista foi sendo aos poucos incorporado (na sua fala, mas não na vida), não era ligado à política ou questões mais intelectuais, apesar de um bom leitor. Foi na convivência que veio a filosofia e outras ciências mais humanas. Apesar de ter tentado muito, nunca senti que nossa família fosse mais importante que seus interesses pessoais, mas havia grande intento de sua parte.

Assim, sem perceber, Pedro foi se esculpindo na tentativa de se adequar à minha fôrma, de ser alguém por mim absolutamente desejado. E conseguiu. A realização do desejo era tão forte em mim, que esta foi uma das causas pelas quais não conseguia sair da relação.

As conversas também eram extremamente prazerosas. Conversávamos sobre tudo que eu propusesse e eu, inclusive, falava por nós dois. Ele era muito mais ouvinte e muitas vezes, 
desenvolvia suas falas em cima das minhas próprias divagações. Sonhávamos com as mesmas viagens, com os mesmos futuros...Pedro era a imagem de Narciso refletida no espelho d'água.

\begin{abstract}
"O narcisismo está relacionado com o mito de Narciso que, segundo a profecia do adivinho Tirésias, viveria muitos anos, desde que não se visse. Após muitos anos, numa tarde de verão, o jovem Narciso, ao voltar de uma caçada pela mata, com calor e com sede, aproximou-se da fonte de Téspios e, no límpido e tranqüilo espelho das águas, viu sua imagem, apaixonando-se por essa sombra e ali, contemplando-se, permaneceu para sempre. No local, nasceu uma flor. A flor é narciso, que floresce na primavera junto das águas ou onde há umidade. Liga-se por isso ao simbolismo das águas. Relaciona-se com os cultos infernais e é encontrada nos túmulos" (Ferreira, 2013, p. 133)
\end{abstract}

Nos contos de Alice, só há duas passagens em que o elemento água é citado: "Alice, os sapos e a solidão" e "Alice nas trevas”, onde a água é parte da cena. Não há interação direta de Alice. Alice nunca se molha, nunca mergulha, nunca vivencia o elemento água em suas aventuras. Como afirma Bachelard (1998, p.o6),

"A água é, então, um ornamento de suas paisagens; não é verdadeiramente a "substância" de seus devaneios. Para falar como filósofo, os poetas da água "participam" menos da realidade aquática da natureza que os poetas que ouvem o apelo do fogo ou da terra."

A água, portanto, não aparece em imagem nos contos de Alice, aparece, porém, como um resplandecente espelho na autobiografia. A água permeia a relação entre mim e Pedro. É esta água do devaneio que, em sua superfície calma, produz o reflexo do eu que busco em minha jornada enquanto Alice. A água é então a intimidade revelada pelo afeto; água que emergiu neste contato com a minha história escrita; a água como devaneio da minha própria intimidade, da minha alma. "Não 
posso sentar perto de um riacho sem cair num devaneio profundo, sem rever a minha ventura..." (Bachelard, 1998,p. 09)

$\mathrm{O}$ riacho primeiro foi o olhar de Pedro. O olhar apaixonado dos amantes que desejam. O olhar parado e profundo, o olhar-lago, onde no reflexo de mim ou do desejo de ser objeto desejado fui seduzida. Neste reflexo-desejo, o devaneio, a imaginação do ser e sua contemplação. Passei a contemplar a imagem imaginada, "O ser que sai da água é um reflexo que aos poucos se materializa: é uma imagem antes de ser um ser, é um desejo antes de ser uma imagem" (Bachelard, 1998, p. 36)

Este olhar-lago de águas calmas, logo se tornou poço profundo. Era preciso que se buscasse além, que um salto fosse dado em busca de tornar a ver-me ou de ver aquilo que desejava ser.

\begin{abstract}
"Certas formas nascidas das águas têm mais atrativos, mais insistência, mais consistência: é que intervém devaneios mais materiais e mais profundos, e nosso ser íntimo se envolve mais a fundo, e nossa imaginação sonha, mais de perto, com os atos criadores" (Bachelard, 1998, p. 22).
\end{abstract}

Ato criador logo transformado em poesia-vida. A busca pela imagem idealizada me fez transformar o cenário da história vivida em paisagem bucólica, em mato, em verde, em horizontes de Sol nascente. Saí da poesia concretista da cidade concreto, para realizar a imagem nas serras de verdes montes. $\mathrm{O}$ amor vivido-sentido trouxe a necessidade de buscar a poesia-vida em lugares mais amorosos, mais sensuais.

"Essa densidade, que distingue uma poesia superficial de uma poesia profunda, nós a sentiremos ao passarmos dos valores sensíveis aos valores sensuais (...) Só os valores sensuais dão "correspondências". Os valores sensíveis proporcionam apenas traduções”. (Bachelard, 1998, p.22) . 
A necessidade de sentir a água em toda a sua densidade e profundidade.

A queda no poço virou queda no abismo. Caí numa água profunda onde nada podia ver. Água turva na escuridão. A dualidade narcísica descrita por Bachelard

“que passa de traços masoquistas para traços sádicos, que vive
uma contemplação que lamenta e uma contemplação que espera,
uma contemplação que consola e uma contemplação que agride.
Ao ser diante do espelho pode-se sempre fazer a dupla pergunta:
para quem estás te mirando? Contra quem estás te mirando?
Tomas consciência de tua beleza ou de tua força?” (Bachelard,
1998, p. 23)

O estar diante de mim ou da imagem desejada de mim, preencheu-me de questões tais como as colocadas por Bachelard. A contemplação do desejo do porvir, do desejo do ser desejado que ainda não era eu, mas uma imagem projetada de mim; forçou a construção de limites sobre o que via, o que imaginava, o que desejava e o que havia de real nas imagens projetadas por esta água.

"Narciso vai, pois, à fonte secreta, no fundo dos bosques. Só ali ele sente que é naturalmente duplo; estende os braços, mergulha as mãos na direção de sua própria imagem, fala à sua própria voz. Eco não é uma ninfa distante. Ela vive na cavidade da fonte. Eco está incessantemente com Narciso. Ela é ele. Tem a voz dele. Tem seu rosto. Ele não a ouve num grande grito. Ouve-a num murmúrio, como o murmúrio de sua voz sedutora, de sua voz de sedutor. Diante das águas, Narciso tem a revelação de sua identidade e de sua dualidade, a revelação de seus duplos poderes viris e femininos, a revelação, sobretudo, de sua realidade e de sua idealidade". (Bachelard, 1998, p. 25)

Esta dualidade revelada à Narciso sobre o ser e não ser revela também o mundo de Narciso que é e não é. Esta necessidade de ver-se tal qual imagem-desejo/imagem-real como um estabelecimento dos limites de quem se é no mundo em que se vive. Tal qual experimentei nesse relacionamento amoroso, no 
qual me doei em amor como gostaria de ser eu amada. Um processo empático, de buscar no outro aquilo que se é, que se quer, que se deseja.

"Nuança delicada de um narcisismo sem orgulho, que dá a cada coisa bela, à mais simples das flores, a consciência de sua beleza. Para uma flor, nascer perto das ondas é verdadeiramente votarse ao narcisismo natural, ao narcisismo úmido, humilde, tranquilo.”( Bachelard, 1998, p. 28).

Este processo de buscar-se, ver-se, contemplar-se, limitarse tal como pessoa em um mundo possível também dentro de seus limites é sempre individual. Por mais que buscasse em Pedro ou em seu olhar aquilo que desejava ser, não poderia encontrar resposta se não me atirasse à fonte em busca de tocar a imagem do desejo. Assim como Narciso, vagava pelo mundo sem saber quem eu era, tendo apenas referências em olhares externos, fragmentos de um eu que se refletiam nos outros que estavam a minha volta. O espelho da água do olhar de Pedro e do amor que senti por ele, me trouxe a imagem de mim, primeiro a desejada, depois a real... A morte veio me transformar em flor. Faço com Narciso a relação simbólica com tempo presente, que existe apenas num devir e, assim que sabe-se enquanto presente, já nesse instante, deixou de existir. Assim, parto, levando apenas a lembrança do que sou, sabendo que como a água que corre, já passou... já não sou.

Foi enfim, a oportunidade de encontrar-me enquanto pessoa, um encontro com a alma. Esse relacionamento amoroso que na vida objetiva se mostrou tão conflitante, foi no mundo simbólico absorvido e vivido como uma grande experiência de busca e descoberta sobre quem sou, porque sou e de onde vim... Foram as andanças pelo meu mundo singular que me tornaram a 
pessoa que buscou por si durante toda a trajetória de vida, até se ver e se reconectar, se reencontrar. Vivi o mito como o mito estava vivo em mim. 


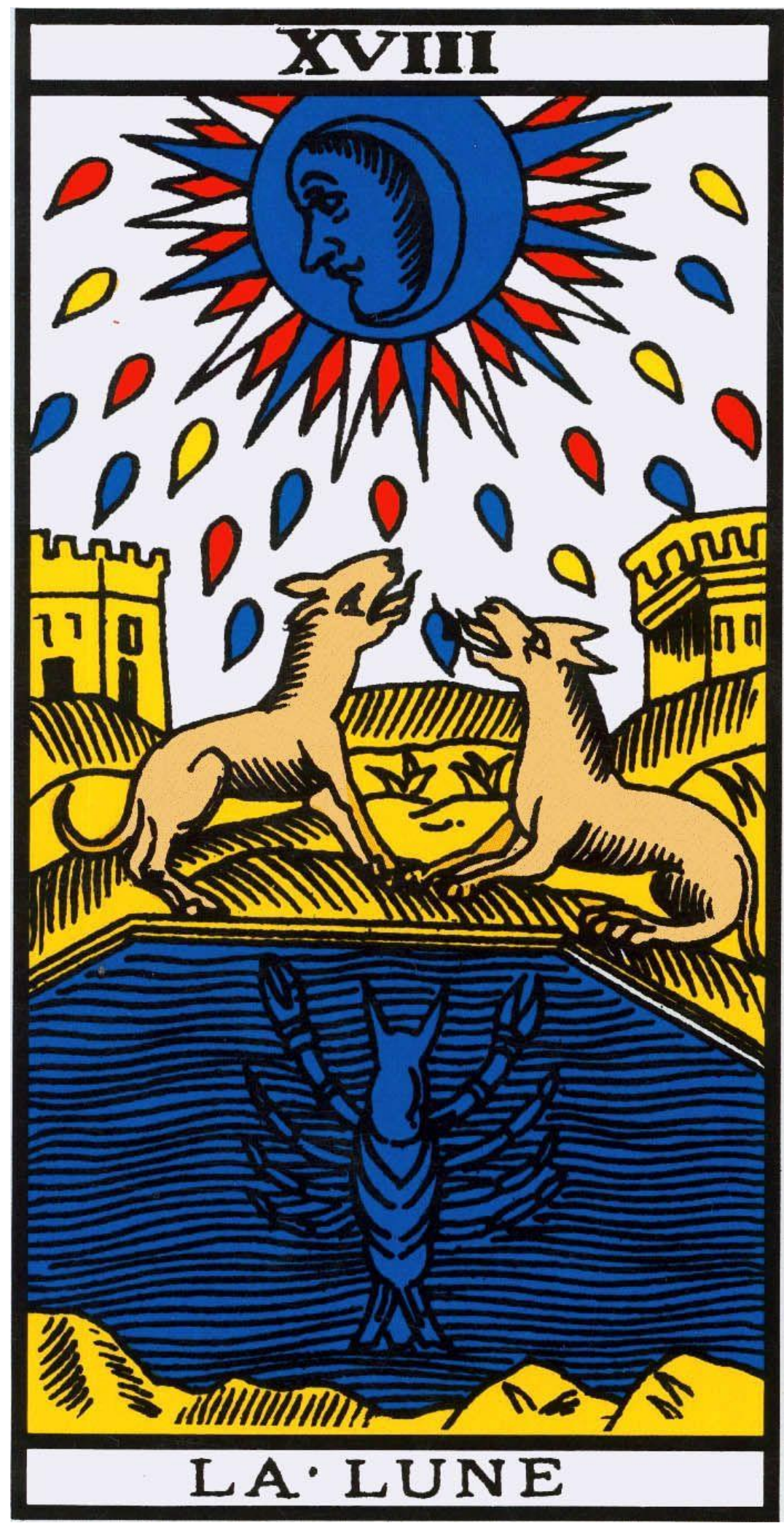




\section{8 - Alice na batalha final}

Certo dia, o guerreiro saiu com o bando para caçar. Alice havia ficado só com Presente e Desejo no acampamento perto do Sol. Alice, que se entretinha com coisas do dia, do fazer, do cuidar, do amar, não se deu conta da invasão.

Quando percebeu, quase tudo já estava em chamas. Alice correu desesperada tentando salvar o que lhe importava. Pegou Desejo pelas mãos e armou Presente com lanças e flechas para que pudessem fugir da morte.

Alice corria o mais rápido que podia, fazia força para que suas asas se abrissem e pudessem se salvar. Alice desejou tanto, com tanta coragem e luz, que suas asas abriram. Foi a primeira vez em sua vida, que aquelas asas a faziam voar em uma situação de perigo.

Alice voou bem alto, carregando consigo Desejo $e$ Presente. Porém, sua falta de habilidade em voos de tristeza era grande. Ela não conseguia juntar forças e ainda carregar aqueles dois meninos a tiracolo. Alice viu Desejo caindo de suas mãos... Logo, Presente também se desprendeu de suas asas.

Alice sentiu raiva. Sentiu ódio por não ter o domínio sobre suas asas mágicas, por não conseguir fazer melhor, por ver cair ao chão Presente e Desejo. Foi tanta dor, que Alice num grito de libertação, abriu suas asas com tanta força e tanta vontade de vingança, que sem nem perceber parou no ar com total domínio de seu corpo.

Alice se virou para enfrentar o que causava a destruição. Ela mesma não sabia de onde vinha tanto terror. 
Ela não conseguia ver nada entre a fumaça e o fogo. Voou em direção ao caos, desejando acabar, com suas próprias mãos, todo aquele inferno. Alice foi se aproximando e sentindo muito calor do fogo que se alastrava.

Chamas eram lançadas a todo o momento e Alice foi em direção a elas, com tanta força e tanto ódio, que não sentia nem mais seu próprio corpo. Alice era só fúria.

Alice não acreditou no que viu.

Alice que nem se lembrava mais do dragão, o viu forte, grande, aniquilador. Ele era muito maior que ela. Era um monstro maior que qualquer outro que Alice ouvira falar.

$O$ dragão havia ficado todo esse tempo se fortalecendo $e$ crescendo para destruir Alice. Ele era gigante e poderoso. Tinha asas enormes e lançava labaredas de fogo pelas ventas. Urrava e voava destruindo tudo que Alice havia construído.

Alice voou bem alto e, num inspirar de ar do dragão, entrou em seu corpo, seguiu até seu pulmão e pegou caminho pela veia que levava ar ao coração. Alice no coração do dragão enfiou uma faca e foi retalhando aquele músculo, como quem entalha a madeira. Alice esculpiu ali a imagem de si mesma. E tantos foram os cortes, que o dragão caiu sem forças e morreu.

Alice demorou dias até conseguir cavar um túnel de saída do corpo do dragão. No dia em que saiu, foi como se tivesse renascido. Alice saiu só, em busca de tudo que havia perdido. Era fim de tarde e o Sol se punha ao leste. Alice seguiu nesta direção.

Ao ver Alice andando tão forte, tão segura de si, tão dona do seu caminhar, percebi que Alice era só uma parte de mim que precisava respirar. 
“..mas tinha que respirar, todo dia"

(Arnaldo Antunes) 


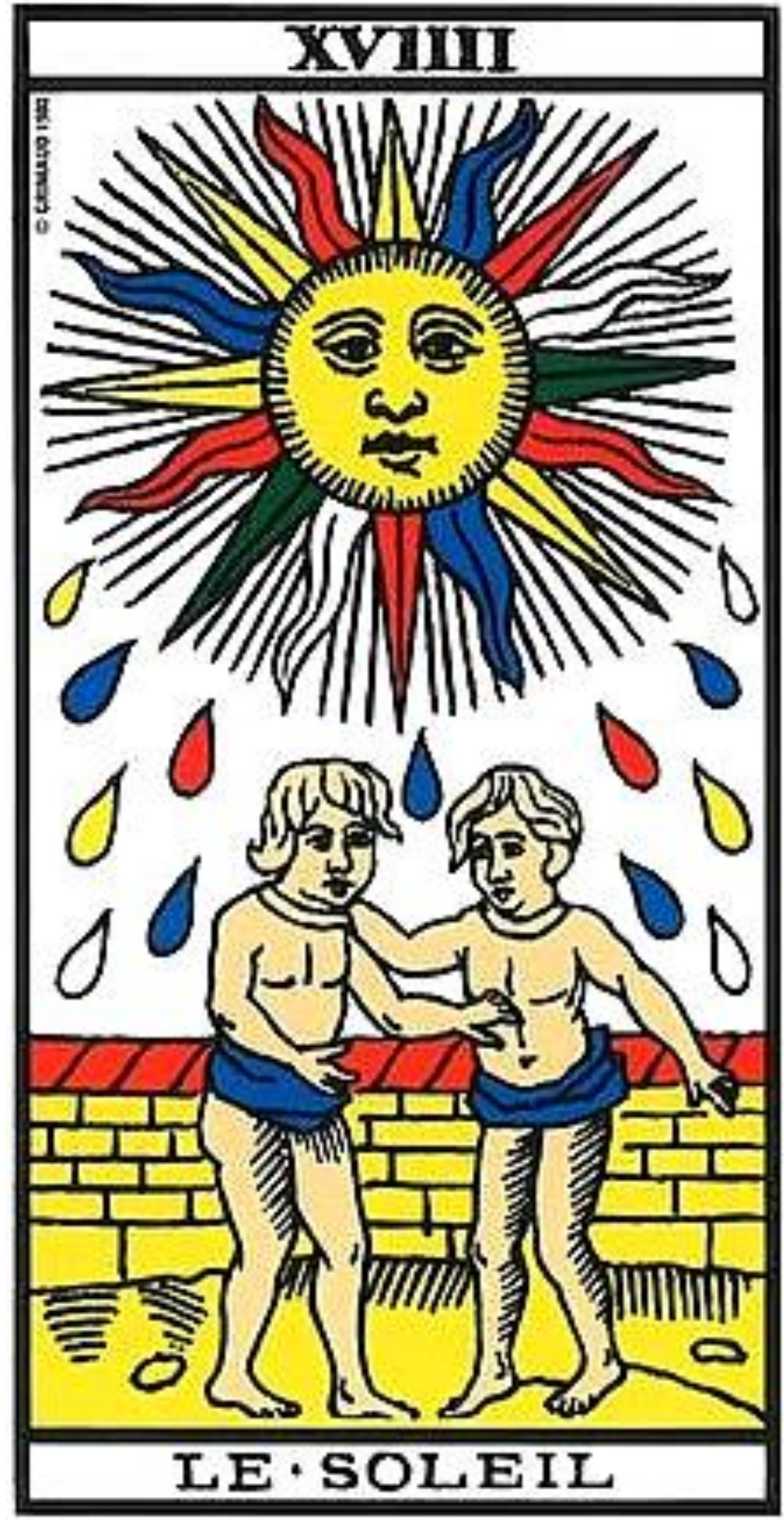




\section{Yaya Massemba}

José Carlos Capinam / Roberto Mendes

Que noite mais funda calunga

No porão de um navio negreiro

Que viagem mais longa candonga

Ouvindo o batuque das ondas

Compasso de um coração de pássaro

No fundo do cativeiro

É o semba do mundo calunga

Batendo samba em meu peito

Kawo Kabiecile Kawo

Okê arô oke

Quem me pariu foi o ventre de um navio

Quem me ouviu foi o vento no vazio

Do ventre escuro de um porão

Vou baixar o seu terreiro

Epa raio, machado, trovão

Epa justiça de guerreiro

$\hat{E} \operatorname{semba} \hat{e}$

Sambáa

o Batuque das ondas

Nas noites mais longas

Me ensinou a cantar

$\hat{E} \operatorname{semba} \hat{e}$

Sambáa

Dor é o lugar mais fundo 
É o umbigo do mundo

É o fundo do mar

No balanço das ondas

Okê aro

Me ensinou a bater seu tambor

$\hat{E} \operatorname{semba} \hat{e}$

Sambáa

No escuro porão eu vi o clarão

Do giro do mundo

Que noite mais funda calunga

No porão de um navio negreiro

Que viagem mais longa candonga

Ouvindo o batuque das ondas

Compasso de um coração de pássaro

No fundo do cativeiro

É o semba do mundo calunga

Batendo samba em meu peito

Kawo Kabiecile Kawo

Okê arô oke

Quem me pariu foi o ventre de um navio

Quem me ouviu foi o vento no vazio

Do ventre escuro de um porão

Vou baixar o seu terreiro

Epa raio, machado, trovão

Epa justiça de guerreiro

É semba ê ê samba á

é o céu que cobriu nas noites de frio

minha solidão

Ê semba ê ê samba á 
é oceano sem, fim sem amor, sem irmão

ê kaô quero ser seu tambor

Ê semba ê ê samba á

eu faço a lua brilhar o esplendor e clarão

luar de luanda em meu coração

umbigo da cor

abrigo da dor

a primeira umbigada massemba yáyá

massemba é o samba que dá

Vou aprender a ler

Pra ensinar os meu camaradas! 


\section{Capítulo Final}

\section{1 - Rosa dos ventos - sentidos teóricos fundamentais e intermediários da pesquisa}

\section{1 - A carta de marear - o mar descrito e os faróis relevantes para a navegação}

Vamos ao mar! Colocar o barco em movimento e partir em busca da compreensão da escrita deste trabalho. Primeiramente, será preciso esclarecer o rumo que escolhemos seguir e a construção do mapa oceanográfico, onde traçamos a rota interpretativa deste texto. Para evitar o perigo de nos perdemos neste mar de histórias, estórias, imagens e pessoas, seguiremos com uma "bússola de investigação poética" (Ferreira-Santos e Almeida, 2012). Nosso aporte teórico da base metodológica da pesquisa.

A "bússola" aponta de maneira assertiva para os conceitos básicos que nos referenciaram durante todo o processo, desde a escolha do tema da pesquisa até a organização das memórias, dos textos e das análises. A direção escolhida para a elaboração de uma pesquisa antropológica do imaginário, que exigiu que eu saísse ao mar para uma jornada de buscas pela compreensão do eu, do outro, do mundo que nos cerca e da forma como interpretamos esta rede de relações - uma

“(...) jornada interpretativa em que a pessoa é o início, o meio e o fim da jornada e que suscita um engajamento existencial (...)E aí, então, nessa explosão de sentidos, é que ocorrem as descobertas da constituição da nossa alteridade, numa reconstituição pessoal de sentidos”.(Ferreira-Santos e Almeida, 2012, p. 44) 
Esta prática de saída, de busca, de experimentação sobre o vivido, sobre as memórias, sobre as histórias de vida, sobre os mitos que nos constituem, caracteriza-se pela ativação da imaginação criativa que propicia a produção simbólica e imagética capaz de

“organizar a compreensão de si, do outro e do mundo em que estamos mergulhados, não como polos isolados, mas como nós de uma trama que se constitui enquanto tal, na socialidade das amarras, laços e cisões, ataduras e rupturas nos fios da existência”.(Ferreira-Santos e Almeida, 2012, p. 44)

A trajetória pautou-se na constituição da pessoa, no processo de formação de um eu em ressonância e consonância aos espaços e vidas por mim experienciados, vividos e imaginados. Eu no mundo, o mundo em mim; um mar que molda a rocha e por ela é barrado a todo instante de seu movimento - o assim chamado "trajeto antropológico". (Durand, 2012, Ferreira-Santos e Almeida, 2012, p. 77)

Neste trajeto considera-se a pessoa sempre em estado inacabado, sempre em condição de ser maior, de ser atuante, de ser passivo, de ser construído, desconstruído e reconstruído. $\mathrm{O}$ ser como prisma do mundo, capaz de decompor em multiplicidade de seres a unicidade da sua existência.

\footnotetext{
“A neotenia afirma a condição de inacabamento humano, o longo processo biológico do desenvolvimento que torna o homem aberto à transformação e, consequentemente, ao aprendizado. Aprendemos ao longo de toda a vida. Logo as pressões pedagógicas dos meios sociais, dos bens e comportamentos culturais estão sempre presentes no processo de formação, atualizando constantemente o imaginário individual e dos grupos. No entanto, embora estejamos em constante transformação, de acordo com as convivências, as relações sociais, as influências culturais, como espécie apresentamos as mesmas capacidades inatas e as pressões pedagógicas que irrompe o imaginário, por meio da mediação operada pelo trajeto antropológico". (Ferreira-Santos e Almeida, 2012, p. 78)
} 
Este ser que nunca é o mesmo, mas que sempre ecoa o que nele reverbera, que cria enquanto se constrói, o faz pela relação que estabelece com o mundo em que vive, um mundo que não é só concreto, objetivo e real. O mundo lido pelo ser humano é interpretado. Não há leitura morta de vida vivida; o ser humano é mais complexo. Sua capacidade de estar no mundo é vinculada ao de ser no mundo e só pode ser a partir daquilo que em si faz sentido. O sentido é dado pela relação do ser com o objeto, da sua interpretação desta relação, da construção simbólica que media o vivido, o real e o imaginado.

\begin{abstract}
“Assim, a apreensão imaginária do mundo e sua consequente organização do real ocorre por meio do trajeto antropológico, o que significa dizer que não há um sujeito em oposição a um objeto, mas uma troca incessante entre o subjetivo e o objetivo, de modo que o sujeito é tão carregado de experiências objetivas quanto a objetividade é de olhares subjetivos (Ferreira-Santos e Almeida, 2012, p. 78)
\end{abstract}

$\mathrm{Na}$ intenção de trazer toda esta subjetividade humana para esta escrita e compreender os processos de formação do sujeito e das relações estabelecidas neste processo - sejam objetivas ou simbólicas - reunimos um relato autobiográfico, dois relatos de histórias de vida e uma estória ficcional de caráter fantástico criado a partir da escrita autobiográfica. Posteriormente, iniciamos uma análise mitohermenêutica de interpretação simbólica do imaginário presente na estória fantástica e sua relação com a autobiografia, buscando entender o processo simbólico de constituição do ser e sua jornada em busca de si. Se consideramos que ser este uno é também múltiplo e se constitui de outros com os quais convive, buscamos ainda as ressonâncias das vidas que se entremearam nestes mares navegados. 
Vidas que não são quaisquer vidas que se cruzam, mas a vida daqueles que se entregam ao outro como mestres-artesãos da alma ou o "mestre apresentador de mundos" como nos traz Ferreira-Santos (2010, p. 86), onde se estabelece a relação mestre-aprendiz, que:

"Exige, de ambas as partes, mestre e aprendiz, a abertura ao
imprevisível da aventura do conhecimento. Isto não quer dizer
apologia ao improviso inconsequente, do descuido ou ao laissez-
faire ingênuo. Ao contrário, esta abertura exige - sob pena de
não se constituir como encontro possível - uma formação sólida,
humanística e consistente, um grande e amplo repertório
consistente de alternativas experimentais, conhecimento
interdisciplinar, fôlego epistemológico, capacidade de diálogo,
uma escuta atenta e sensível, uma preparação constante que
servirá de bússola (agulha de marear), na navegação
epistemológica no mar desconhecido, que é sempre o encontro
com o Outro. (Ferreira-Santos, 2010, p. 86-87) Já, no mar, as vidas vão cardumes. Foi preciso dimensionar a escrita em dois momentos de leitura-análise: a dos contos, que trazem, um a um, momentos específicos da formação do eu-aprendiz e dos mestres, paralelo à construção e compreensão do mundo simbólico por onde caminha nossa Alice (personagem da estória fantástica). E outro, da análise da jornada de Alice enquanto arquétipo da mulher selvagem em busca de sua natureza interior. Assim, nossa pesquisa é ainda, do tipo mitohermenêutico, isto é,

"o trabalho filosófico de interpretação simbólica, de cunho antropológico, que pretende compreender as obras da cultura e das artes a partir dos vestígios (vestigium) - traços míticos e arquetipais - captados através do arranjo narrativo de suas imagens e símbolos na busca dinâmica de sentidos para existência, se instala e é herdeiro desta filosofia latinomediterranea, produtora e produto da cultura latina (Ferreira-Santos e Almeida, 2012, p. 119) 


\section{2 - O marinheiro e o mar - sobre o ser que se constitui durante a jornada}

O eu marinheiro no mar... De que serve tanto mapa, tanto mar, tanto barco, se não tiver ninguém para navegar? Vamos seguir pensando no homem que leva o barco, segue no leme e se constrói nas andanças que tem pelas águas que trazem um horizonte sem fim. O barco quando sai do porto, sai direcionado para o infinito. Só bom marinheiro é que consegue ver ponto de chegada, saindo para lugar nenhum que se possa ver. Só imaginar.

Eu entrei no barco pensando que o barco era eu. No começo é assim, nos sentimos dono da embarcação. Pensamos que todo o controle está em nossas mãos. Tem até marinheiro de longa vida que ainda pensa dessa forma. Pensa que o mar se aprende em livros, em cadernetas, em anotações. É a pedagogia da escola. Essa, que pressupõem que a vida se dá sentada num banco à espera de que todo conhecimento seja dado, seja lido, seja apenas falado por um alguém que sabe um pouco mais. É essa pedagogia que nos ensina apenas a ser pote vazio; não o do conto chinês que ensina sobre os valores que se carregam num pote vazio, mas aquela que considera o sujeito um ser passivo de ser moldado, apreendido e conduzido cego a um ponto fixo onde se deseja chegar.

Mas o mar vem e ensina que bom marinheiro se faz na vida, nas andanças, nos trajetos, no se perder entre as águas. $\mathrm{O}$ bom marinheiro, assim como qualquer viajante, está sempre a crescer, a se aperfeiçoar. Sai em viagem, sempre como a primeira vez, destemido e ciente de que toda viagem é única. É essa 
pedagogia da escolha, que considera a pessoa sempre inacabada, sempre em formação. Pedagogia esta, que parte de um princípio de que a educação é um movimento do sair de si, do buscar-se fora.

“A partir de seu étimo original 'ex ducere' - conduzir para fora reafirmamos aqui a percepção de nossa humanitas (potencialidade humana em seu Selbst - si-mesmo). Todo processo educativo se revela como percurso de autoformação, independentemente de nosso 'furor pedagógico' (querer controlar o processo, segundo finalidades e objetivos, de forma instrumental que se traduz na "educação para...'). Neste sentido, a educação é um fim em si mesmo. Condição de possibilidade de atualizar a humanitas na construção cotidiana e experimental das práticas educativas sem modelos apriorísticos e, dessa forma, abertos à existência em seu fluxo dinâmico e imprevisível." (Ferreira-Santos, 2010, p.59-6o)

Este sair de si pressupõe uma abertura para o novo, para o percurso que segue. Tudo é válido, tudo é momento de aprender. Desde o olhar pelo horizonte em busca do que pode ser visto, até aquilo em que só em imaginação podemos encontrar. Os mapas antigos de navegação já nos diziam isso. Instrumentos de rota que alertavam sobre os perigos do imaginário ao longo do caminho. Eram cartas náuticas que representavam monstros, mares revoltos, rotas de navios fantasmas.... Tudo estava lá. Se considerava que, aquele que saía ao mar, precisava saber ver o visível e o invisível aos olhos. Assim, como a vida é. A vida que vem como um itinerário em que o sujeito está sujeito ao viver. A este processo, chamamos "itinerários de formação":

"valorizam a complexidade, os processos simbólicos que perfazem a cultura, a razão sensível, a construção do si, a obra de arte e a arte-educação, a dimensão ética e estética da vida, a pluralidade e a poética de uma pedagogia da escolha e de todas as atividades fundamentais para a formação da pessoa”. (FerreiraSantos e Almeida, 2012, p. 143) 
Considera-se que tudo ensina e, em tudo, um pouco se aprende. Que nada é conclusivo, que não há absoluto controle sobre o percurso, que é preciso liberdade e respeito pelas escolhas dos itinerários que se deseja percorrer. A pessoa aberta ao aprender, está no mundo como o marinheiro. Pode carregar em si um saber ensinado pelo livro, pela escola, pelo professor; mas está em busca de aprender nos passos da sua longa jornada.

"Nessa perspectiva antropológica, o homem é uma trajetória, projeta seu mundo, narra a si mesmo. E nessa narrativa, escolhe o sentido simbólico de sua existência, inscreve-se no mundo por meio do trajeto antropológico, das escolhas que faz entre sua subjetividade e as intimações do mundo objetivo". (FerreiraSantos e Almeida, 2012, p. 154)

Bem se sabe que, para cada pessoa que vai ao mundo, há um mundo inteiro a lhe esperar, com todo o trágico que isso possa significar. É a tragédia humana, aquela sobre a qual os gregos já narravam suas estórias. A tragédia que inclui em si o percurso, o destino, as escolhas, as conquistas, as alegrias e as frustrações - desde fortuito nascimento, que não dá chance nem de escolha. Já é a vida se anunciando, já nos diz de início que nem tudo será opção... É preciso ter leveza, ir transformando cada trecho percorrido em história, em um pedaço de si, enxertando este mundo único que está para cada sujeito que chega, em "versinho da alma”, em cantiga de ninar, em vida a se narrar.

Esta vida que se narra em história traz a pessoa em sua completude. Traz a jornada do sair de si, por meio da busca do si. Daí, pressupomos que esta pedagogia da escolha, que considera a pessoa em seu itinerário de formação, quando a vê como pessoa que sai em busca do ser-maior, considera que este movimento é também o de encontrar-se. Ora, para entender quem sou, é 
preciso que me veja e como ver algo do qual sou parte? Quando saio para o mundo, descubro a porta de entrada para dentro de mim. Portanto, o ato de transformar a vida em narrativa é assumir a autoria da vida em obra, é permitir-se encontrar os "idens" aos quais nos juntaremos na construção da própria identidade, a partir da compreensão da própria subjetividade sempre neste movimento de ir e vir. Que Josso (2007) considera um movimento em que aborda

\begin{abstract}
"o conhecimento de si mesmo pelo viés das transformações do ser - sujeito vivente e conhecente no tempo de uma vida, através das atividades, dos contextos de vida, dos encontros, acontecimentos de sua vida pessoal e social e das situações que ele considera formadoras e muitas vezes fundadoras, é conceber a construção da identidade, ponta do iceberg da existencialidade, como um conjunto complexo de componentes. De um lado, como uma trajetória que é feita da colocação em tensão entre heranças sucessivas e novas construções e, de outro lado, feita igualmente do posicionamento em relação dialética da aquisição de conhecimentos, de saber-fazer, de saber-pensar, de saber-ser em relação com o outro, de estratégias, de valores e de comportamentos, com os novos conhecimentos, novas competências, novo saber-fazer, novos comportamentos, novos valores que são visados através do percurso educativo escolhido". (Josso, 2007, p.420)
\end{abstract}

Nesse constructo do marinheiro que vai ao mar e já tem ciência que o mar é sempre a água nunca antes navegada, organiza a viagem em registro. Mesmo que o ponto de chegada e partida sejam os mesmos, o bom marinheiro sabe que andar pela vida, exige um olhar observador e atento e, sobretudo, memória aguçada. O registro das memórias é sempre bom companheiro daquele que não pretende deixar de navegar.

Nesta tese, esse registro veio pela escrita autobiográfica, momento em que pude organizar meu próprio itinerário de formação, tomar consciência sobre as escolhas, experiências e vidas que contribuíram para o processo do transformar-me em 
quem sou hoje. O olhar para esta escrita e a reflexão sobre o processo do me constituir sujeito de minha própria vida em obra, permitiu que compreendesse meu lugar enquanto pessoa atuante, ao mesmo tempo que passiva ao ser transformada, independente da minha vontade, enquanto ser social e pessoal. Influenciada pelo coletivo, pelo político, pelo econômico, porém, ainda assim, detentora de um conhecimento individual e único; que me capacita para transformar e transformar-me, de modo a agir de forma mais consciente no mundo. Josso (2007), afirma que

“O processo de formação que caracteriza o percurso de vida de cada um permite trazer à luz, progressivamente, o ser-sujeito da formação, vê-lo tomar forma psicossomaticamente, psicologicamente, sociologicamente, economicamente, culturalmente, politicamente, espiritualmente, numa sábia e singular teia, produzindo assim um motivo único ('peça única' nas artes visuais). A consciência de ser (ativamente ou passivamente) sujeito de sua história, através de todos os ajustes que foi preciso fazer, permite ter a medida do que está em jogo em toda a formação: a atualização do sujeito num querer e poder ser e vir-a-ser e sua objetivação nas formas socioculturais visadas, as que já existem ou as que ele tiver que imaginar". (Josso, 2007, p.423)

Considerando, então, toda a complexidade implícita e explicita na construção da identidade e da subjetividade do sujeito, enquanto autor de sua vida em obra, é preciso considerar que toda narração de vida, apesar de pautar-se em fatos reais e vividos, é também ficcional porque traz em si a ideia da pessoa como invenção de si mesma, como colocado por Josso (2007)

“a invenção de si necessita, não somente de um discurso sobre si, mas de projetos de si. De fato, a história de formação só é possível como processo de conhecimento de um sujeito que postula e, portanto, imagina poder vir a ser esse sujeito plenamente. Assim, é preciso poder imaginar ser - e tornar-se efetivamente -, tanto único porque singular como reconhecível porque socialmente identificável”. (Josso, 2007, p.434) 


\section{3 - Os mestres do mar - as ressonâncias e os encontros com aqueles que vêm nos guiar}

No início, quando citamos o marinheiro e seu processo de formação que se dá no barco, nas viagens, nas experiências e trocas com o mar, não falamos do mestre da embarcação. Este mestre nem sempre pertence ao escalão dos oficiais, mas é ele o responsável por guiar a viagem. É ele que vai à frente, determina os postos, as funções, determina as mudanças de rotas, quando necessárias; resolve os problemas e auxilia nas travessias dos mares revoltos.

No mar, assim como na vida, é preciso seguir acompanhado de um mestre. Se o saber-se ser só se dá na presença de um outro, este outro já é, em si, um mestre porque nos põe a olharmos para aquilo que não somos e nos limita um pouco sobre a verdade de quem podemos ser. Mas não podemos tomar qualquer um como mestre. $O$ mestre, como na embarcação, é aquele que sabe mais do barco, do mar, dos marinheiros, das batatas a descascar e da vida. Pode não ser aquele que mais leu sobre motores, ou o que mais viajou a bordo de outros navios, mas é aquele que inspira segurança sobre o que sabe e sobre o que, com ele, é possível aprender. Ele é aquele que fala do horizonte sem se perder no infinito. Ele sabe para onde vai e, por isso, pode oferecer possibilidades de caminhos para quem vai à vida, em busca de encontrar a si mesmo. (FerreiraSantos, 2010, p.59-60).

Nenhum marinheiro escolhe seu mestre, ela entra no barco e a relação é dada. Na vida, o encontro é que determina esta relação. Nos diz Gusdorf (2003) 
"O discípulo tem a necessidade do mestre, é evidente. Não pode haver discípulo sem mestre; é só depois do encontro com o mestre que o discípulo descobre ao mesmo tempo a realidade e o sentido desta busca. Ninguém vai lançar-se à procura de um mestre, seja ele quem for, como criado à procura de um trabalho; aquele que partisse para a aventura arriscaria muito encontrar um sedutor, não um mestre. A vida espiritual, antes do encontro do mestre, é feita de espera e paciência, mas esta expectativa ignora que o é, e esta paciência pode tornar-se simples passividade, soçobrar na monotonia e no tédio, se o mestre não vem, como acontece no conto, despertar a alma adormecida no bosque" (p. 191)

O mestre é aquele que fará o convite que, sendo aceito, tomará seu discípulo pelas mãos e o conduzirá pelos caminhos que o levarão ao encontro de sua própria identidade e da “justificação de sua existência” (Gusdorf, 2003, p. 191). Nem sempre o mestre sabe-se mestre. Muitas vezes a maestria é revelada numa conversa casual, num encontro imprevisto, onde há um reconhecimento do discípulo por aquilo que busca, que na verdade, nada mais é do que uma revelação de si no outro. Segundo Gusdorf (2003, p. 192) este encontro

“(...) exprime uma revelação de si, o acesso a uma consciência superior. A partir do momento em que ouve a palavra do mestre, o discípulo fica vencido e convencido. Não se torna outra pessoa; afirma-se a si mesmo".

Em nosso estudo, cito dois mestres. Dois sábios homens que trouxeram luz à minha existência. Estiveram comigo em momentos distintos da minha vida. O primeiro momento em que fui conduzida por um mestre, foi no encontro com Matheus, na Universidade de São Paulo, em São Carlos. Matheus, como foi apresentado ao longo da tese, me orientou na vida e nos estudos acadêmicos. Reconheci Matheus em sua maestria, não pelas palavras que proferia ou pela excelência na atuação como pesquisador. O reconhecimento foi além, foi na humanidade, na 
ideologia, na forma digna e honesta com que conduzia a própria vida.

\begin{abstract}
"todo mestre autentico é um mestre de humanidade. Aos olhos do discípulo que o reconheceu, e que portanto nele se reconheceu, o mestre é um grande homem, isto é, um homem. Como ensina uma fórmula célebre, um grande homem é um homem junto ao qual nos sentimos grande". (Gusdorf, 2003, p. 194)
\end{abstract}

Foi este o sentimento que conduziu esta relação mestreaprendiz. Eu desejei estar mais perto, desejei aprender com ele, desejei ouvi-lo e acompanhá-lo durante parte de minha jornada. Matheus era a representação de algo que eu desejava ser enquanto pessoa. Trazia consigo uma figura de sucesso na minha área de trabalho, Matheus é uma referência em Educação Ambiental. Mas em seus olhos sempre houve mais, sempre trouxe mais do que só um comprometimento acadêmico. Era uma maestria com a vida. Um jeito simples e humilde de lidar com toda magnitude. Matheus me conduziu para um caminho com mais sentido para as minhas buscas. No meu desejo infantil, buscava apenas por me tornar referência em algo, buscava a máxima especialização, o controle sobre as palavras e o saber. Matheus com atitudes, mostrava que de nada valiam palavras e saberes, se não houvesse vida implícita e explicita no buscar-se por ser algo. Assim, cheguei no ambientalismo. Ser referência ficou pequeno para o tamanho do mundo que Matheus apresentou.

Eu não desejava mais ser modelo de outros ou para outros, passei a desejar ser maior para mim mesma. E este mesmo é o papel do mestre.

"O modelo suscita imitadores: o original desencoraja-os, de tal modo que sua singularidade se afirma além de todo alcance (...) $\mathrm{O}$ prestígio do mestre mobiliza a personalidade adormecida; a 
autoridade do mestre exerce uma ação de opressão e aspiração ao mesmo tempo. Deixando de lado, mesmo, qualquer ensino particular, ou uma palavra que me seja pessoalmente endereçada, a presença do mestre impõem-se a mim como a confirmação de um melhor-ser de que eu não sou capaz" (Gusdorf, 2003, p.204-205)

Matheus nunca considerou-se mestre. Não soube que teve em minha vida essa importância até que eu o procurasse para a entrevista que utilizei para elaboração da tese. Matheus me disse: "Eu tinha um olhar pra você diferente, eu gostava, eu queria te ajudar, eu não sabia como, mas eu queria te ajudar, entendeu? (...) Depois acabei te conhecendo ao longo dos anos do curso e percebi que tinha alguma coisa que eu tinha que estar ajudando (...) Eu fui entendendo mais, mas foi por sentimento (...) Como se fosse um pai e filho, não sei, uma coisa assim, aí, surgiu a oportunidade da Fapesp, convidei, você arrumou a bolsa pra você e nesse período eu fiquei mais próximo de você, então eu fui aprendendo a conhecer melhor e ficou um sentimento mais profundo, diferente de qualquer outra pessoa que vem aqui... um aluno... é diferente (...) Eu acho que é por aí e tem essa história dessa trajetória (...) Isso que eu acho legal no curso, um curso que todo mundo tenta ajudar um aos outros (...) Eu procuro fazer essa ponte da ligação afetiva das pessoas (...) Eu acho que não é só aquela coisa técnica. Pessoas que criticam o curso e que eu não estou nem ai, sabe? O curso é muito humano, isso eu dou valor no curso, não é só conhecimento, conceito, essas coisas, é importante também, lógico, mas a parte humana, eu acho fundamental... Mas o meu olhar para você era um olhar diferente...um olhar de carinho para você... muito carinho por você (...) eu fico até emocionado". 
Eu também, Matheus, fico emocionada!

Este foi o mestre que me ensinou a caminhar em busca de ser uma pessoa mais humana, mais gentil, mais cuidadosa com o mundo. Matheus me conduziu, em sua maestria, por uma busca que deixou de ser pela técnica e passou a ser pela vida. Gusdorf, assim nos diz

"O discípulo sofre uma influência tanto mais decisiva quanto menos ela for literal. Através de um conjunto de operações e de transposições, são as atitudes perante a vida que se questionam, no próprio princípio de orientação. É nesse sentido que a ação do mestre se apresenta como criadora, na medida em que produz no discípulo uma mudança de figura e um direcionamento”. (p. 206)

Como toda relação entre discípulo e mestre, eu segui meu caminho. Nos afastamos e fui navegar no mar sozinha, levando comigo todo o ensinamento que Matheus trouxe. Segui. Porque é do verdadeiro mestre, deixar que seu discípulo siga em sua jornada "É esta separação, material e espiritual, que permitirá discernir no seio da relação mútua o que havia de momentâneo e o que há de eterno" (Gusdorf, 2003, p. 208)

Navegando no mar, encontrei os terríveis monstros de águas turvas do mar revolto. Sem orientação, a vida me fez, então, mais uma vez discípula. Foi meu encontro com Mestre Alcides. Mestre Alcides, como já colocado, é mestre de capoeira. Um dia ele me explicou que na capoeira o título de "mestre" tem origem no cais. A capoeira que conhecemos hoje teve sua manifestação mais forte na Bahia e de lá que vem nossas maiores referências ancestrais. Ele contou que a capoeira era jogo de escravo e, no porto, eles podiam jogar mais livremente nos momentos em que não estavam trabalhando. Os negros escravos que trabalhavam nos navios tinham seus mestres das embarcações e era sabido que mestre, era o que sabia mais. 
Assim, passaram a chamar de mestres na capoeira, aqueles que ensinavam aos outros, que jogavam melhor, que tinham mais ginga, que vadiavam melhor.

Portanto, meu mestre do mar neste momento é Mestre Alcides. Mestre do mar e da capoeira porque foi, acima de tudo, meu mestre na vida. Conheci Mestre Alcides, quando nas andanças de buscar por mim, cheguei na capoeira. Mestre dava (dá) aulas na Escola Municipal Desembargador Amorim Lima, no Butantã, em São Paulo. Meu contato com a capoeira era quase nulo; na vida, havia visto algumas vezes roda de capoeira. Não sabia nada, mas resolvi enfrentar o desconhecido. Ao chegar à capoeira, a vida mais uma vez promoveu o encontro mestreaprendiz. No momento em que conheci Mestre Alcides, me reconheci sua discípula. Como nos diz Gusdorf (2003) o encontro entre mestre e aprendiz, traz um si, um sentimento de um conhecer-se antes do encontro, a "impressão de se conhecerem há muito tempo, ou de terem vivido juntos uma vida anterior" (p. 197). Talvez porque este mestre tenha me conduzido ao caminho da ancestralidade ao me levar para onde, em algum momento da vida, havia me esquecido.

Esse foi o mestre que me trouxe para mais perto de mim, para mais perto do que eu já havia sido sem nem querer ser. Ele me levou de volta aos idos da infância, aos tambores que, quando ainda criança, me faziam sambar na roda de samba dos quintais do meu passado. Mestre Alcides me levou para a roda, para a roda da vida. "Quem encontrou seu mestre julga a princípio terse encontrado a si mesmo, pois a procura do mestre tenta remediar a angustia do ser". (Gusdorf, 2003, p. 201) 
Foi pelas mãos de Mestre Alcides que pude me reconectar com a ancestralidade negra perdida em minha identidade. Ele trouxe o canto, a ginga, a oralidade como forma do ensinar e aprender. Um encontro que trouxe ainda mais angústia sobre tudo que precisava rever, sobre o todo que precisava ser descoberto, redescoberto. Este mestre foi o mediador entre dois mundos - o real e o imaginário, o do corpo carne e do corpo alma. Rubira (2015) nos fala sobre este encontro com o mestre ancestral:

"Quando um possível mestre se colocar face a face com um possível aprendiz, temos espelho frente a espelho, entre eles a estória tradicional se revela como um caminho sem começo nem fim, anúncio e prenúncio de vida humana, uma estrada que se constitui pelo próprio ser humano que a trilhará. Ela é a possibilidade cultural que alargará nossos horizontes internos e externos, a partir de uma presença humana, que se coloca honestamente frente a outra. Posição esta que coloca o mestre humano e humanizador como um iniciador cultural, conhecedor de possíveis caminhos" (Rubira, 2015, p.230-231).

Mestre Alcides, assim como Matheus, só soube do tamanho de sua importância em minha vida, durante a entrevista para este estudo. Ele nos disse: "Então, é dificil a gente saber medir, porque eu acho que o mestre, ele é aquele que não carrega o aprendiz, não é ele que faz tudo, ele só mostra o caminho, eu acho que ele dá um start e depois para frente é a pessoa. Eu acho que o mérito maior é seu, não é meu, porque quando você entrou, que viu (...) Eu não sei o tamanho da sua visão... o mestre nunca sabe o tamanho da visão do iniciante, eu vou inverter tudo, porque geralmente o mérito vem só para o mestre, eu acho que o mérito não é do mestre, o mestre tem o mérito de fazer um pontinho, abrir um pontinho e, depois isso, ele faz do jeito dele lá, e tudo isso vai para o aprendiz, ele tem 
uma visão, ele que já tinha uma visão ampliada, só faltou alguém dar o start (...) Você foi uma pessoa que não tinha nenhuma vivência nesse meio, que estava guardado aí, acho que tinha, mas estava guardado, só estava faltando alguém, VOCÊ, né? Porque foi você que foi lá no Amorim Lima, não fui eu que fui lá 'Ah, Carla, você sabe', você que foi atrás, você que buscou, você que viu, você que teve a sensibilidade. (...) Eu poderia fechar a porta, também, né? Poderia chegar lá e depois nunca mais voltar, nunca mais querer isso e ir pra um outro lado, então, é o mestre, ele tanto pode abrir como pode fechar, como é do meu sentimento aquela coisa que eu falei da inclusão, que a capoeira é muito exclusiva, quantas pessoas deixaram de fazer capoeira, por causa do mestre que fechou a primeira vez? A minha percepção é disso, é de não ver, olhar para a pessoa e falar: 'Ah, você não tem jeito para capoeira', que é o que se fazia muito...'Você não leva jeito'... É abrir para todo mundo e tratar todo mundo igual. Igual diferente, que nem todo mundo é igual, quando você fala de igual é de ser humano, mas se você fala de diferente, você tá vendo igual com tratamento diferente, você vai tratar diferente, você está respeitando as habilidades, o gênero, as dificuldades, as facilidades, a forma de entendimento, e, aí, é que você chega no ponto que 'Ah, eu gostei desse nome, eu gostei disso, eu vou partir para essa área da pesquisa, do estudo', e você já tinha tudo isso... O que a gente faz... que o mestre, no meu caso faço, é orientar...'Olha, acho que por aqui... não, assim', isso desde a roda, 'Não faz assim, faz assado' e com cuidado. Você já tinha essa, vamos dizer, essa aptidão... aptidão é uma coisa que é nato, ninguém coloca nas pessoas e muitas vezes gostar não é ter aptidão (...) Não estou 
dizendo aptidão para roda, chegar lá e dar mortal, você esquece isso... você na roda, vai ser você... você vai ser você a vida inteira... você não precisa imitar ninguém... não precisa copiar de ninguém... não precisa desejar ninguém, você vai ser sempre você e vai ser o maior engano o mestre chegar pra você e falar: 'Não, você tem que jogar assim, tem que jogar assado..... Não! Você tem que ser você mesma e você é você mesma... A sua ginga é a sua, a única coisa que o mestre pode falar é 'Carla, faz assim porque assim...', aí, é uma coisa de anatomia mesmo. 'Olha se você fizer assim, você vai machucar', é a visão anatômica, de fisiologia de esforço, de anatomia de esforço, de sinesiologia que é o estudo dos movimentos, dos ângulos do corpo, né? Que eu conheço...”

Assim é meu mestre. Nesta fala há tanto... Mestre Alcides trouxe a definição de mestre exata como a que lemos em diversos autores que tratam do tema (Gusdorf, Ferreira-Santos, Rubira...). E seu conhecimento é da vida. É do seu aprendizado enquanto aprendiz, enquanto capoeirista, enquanto artista de tradição, enquanto griot. É do velho homem de luz, que com toda sua sabedoria, esclarece que o seu papel é o de mediar, é o de apresentar novos mundos. Nunca de tomar para si, a rota do caminho do aprendiz. Complementando Mestre Alcides na sua insuperável definição de maestria, cito Gusdorf,

"O discípulo nunca está diante do mestre como barro entre as mãos de um escultor, ou como um fantoche a que se puxam os cordelinhos. O aluno mais aparentemente submisso ainda escapa ao domínio espiritual. Pois o sentido de uma vida pertence propriamente a esta vida; o sentido de uma vida é que esta vida tem um sentido, mas esse sentido só pode ser apreendido em função da situação do ser que ele indica, do valor que orienta. (...) Toda influência real é alusiva. Aquele que fala não é senhor das palavras que pronuncia; elas lhe escapam para ressoar no interior de um outro espaço vital, onde irão despertar ecos imprevisíveis. 
Nos confins das vidas pessoais que a relação põem em jogo, produzem-se interferências, uma interação espiritual, que escapam de qualquer controle técnico - comunicação para lá da comunicação e apesar da comunicação" (Gusdorf, 2003, p. 209)

No fim desta fala, Mestre Alcides não está mais em entrevista; está como mestre falando com sua aprendiz... Porque é assim mesmo. Hoje não treino mais no mesmo grupo do mestre. Acabei indo buscar por outros caminhos da capoeira e cheguei na capoeira angola, que é onde o jogo bate mais forte no meu coração. Porém, nunca destituí Mestre Alcides de seu lugar. Na capoeira, o primeiro mestre é aquele que inicia o discípulo na arte do jogo; costuma ser o de maior importância na vida do capoeirista, é o que se torna inesquecível. Assim, Mestre Alcides será sempre meu mestre.

Durante a escrita deste trabalho, pude buscar ressonâncias entre a vida dos mestres e a minha própria. Foram muitos os pontos em que, mesmo muito distantes em geografia ou tempo, superamos obstáculos, lutamos, sofremos, sobrevivemos e continuamos a buscar. Se o mestre é reconhecido pelo seu discípulo como uma revelação de si, não posso negar que o que vi nestes homens e que de certa forma buscava em mim, era a capacidade de lutar, de ser forte e acreditar. O que esses mestres ensinaram, com toda a maestria que possuem em seu corpo-fala-coração, é não desistir de buscar por mim... E cá estou, navegando no mar, em busca de me encontrar. 


\section{2 - Projeções cartográficas - o método do contorno do vivido e da imersão no mundo simbólico}

\section{1 -Memória, imaginação, lembrança e promessa - a escrita autobiográfica e criação dos contos de Alice.}

Quem sou?

Por que sou?

De onde vim?

O que há em mim que de mim se esconde?

Quem são os outros que habitam em mim?

Quem sou eu em tantos outros?

Quem sou eu e os outros, senão lembranças do que somos nós?

Podemos começar a trabalhar sobre o processo de elaboração desta tese por meio dessas perguntas. Tudo começou na escrita de um memorial que, mais tarde, se transformou em uma autobiografia ficcional. A escrita autobiográfica veio por meio do resgate das memórias, do passado que estava guardado em algum lugar de mim, mas que também era presente, dado o fato de que eu não seria quem sou, não fosse o passado que vivi.

O acesso às memórias - o que são memórias?

"A mnenme - memoria designa a simples presença no espírito de uma imagem do passado concluído: uma imagem do passado vem-me ao espírito; a esse título, é um momento passivo - um pathos- oposto ao aspecto ativo da reminiscência" (Ricoeur, 2006, p.125) 
As memórias resgatadas para este trabalho foram em tons reminiscentes. Busquei-as em minha alma, foram chegando em fragmentos e logo pude juntá-las, dando vida a uma história. "Se um corpo humano foi afetado uma vez por dois ou vários corpos simultaneamente, assim que a alma imaginar, mais tarde, um dos dois, recordar-se-á também dos outros" como citou Ricoeur (2006, p. 127) sobre a "Ética", de Spinoza. Assim é a reconstituição do passado guardado na memória; se pesca um peixe e ao lembrar-se dele, vem todo o oceano.

Nunca vem um oceano não visto, não sentido, não vivido; vem a experiência, o que nos toca, o que nos tocou em essência, em pele, em cheiro, em gosto, em vento. Vêm as sensações de estar no oceano, na parte do oceano na qual navegamos ou mergulhamos.

"É sob o signo da associação de ideias que é colocada essa espécie de curto-circuito entre memória e imaginação: se essas duas afecções estão ligadas por contiguidade, evocar uma delas portanto imaginar - é evocar a outra - portanto lembrar-se. A memória, reduzida à recordação, opera assim, na trilha da imaginação". (Ricoeur, 2006, p. 127)

Para a escrita do memorial, foi preciso que eu buscasse em minhas memórias tudo o que vivi, com a promessa de ser quem sou e manter-me fiel às lembranças resgatadas. Porém, nem tudo que vivi pode ser resgatado. Há aquilo que vivemos e que não podemos recordar, num sentido de preservação ou por apagamento da memória, do tempo que foi e que não pode voltar. O passado resgatado é presente, na medida em que eu vivo em memória aquilo que já não vivo mais. A questão do tempo - daquilo que foi e que se torna presente se resgatado em ideias, imagens, sensações. 
Há, ainda, o profundo do oceano, aquele ao qual, apesar da nossa imersão, não temos acesso, mas que está ali, abaixo de nós, constituindo o oceano no qual estamos submersos. Um oceano ao qual não podemos tocar, não podemos ver, mas podemos intuir pela força das águas que forçam nosso corpo e nos fazem mover em busca de mantermos vivos - o inconsciente, o responsável pelo esquecimento das memórias, onde não há presente, passado ou futuro. Mas há um eu esquecido que, ainda assim, age sobre o eu presente, sobre a vida que se constitui no agora.

"Esse esquecimento ativo, que faz da rememoração um 'trabalho', é então inseparável da teoria do inconsciente, da qual ele se torna um anexo; paradoxos surpreendentes são então propostos, tais como 'o inconsciente ignora o tempo', 'o inconsciente é indestrutível'. (Ricoeur, 2006, p. 128)

$\mathrm{Na}$ escrita da autobiografia, que julgamos ficcional exatamente pela impossibilidade do resgate do oceano vivido em toda a sua completude, ou seja, já como uma obra resultante do resgate das memórias possíveis, apenas como uma lembrança do que pôde ser resgatado, houve ainda a intenção de tentar trazer ressonâncias desse profundo onde a alma toca, mas o olho não vê; trazer para a superfície imagens sobre esse profundo esquecido e inacessível que o recordar não consegue chegar; aquilo que estava no inconsciente, mas que, em tempo presente, ainda atua como sombras que agem na escuridão no manipular a própria vida, imagens ocultas, porém vivas na memória esquecida.

A potência ao quadrado da ficção nesta autobiografia é Alice. Os contos de Alice são estórias construídas a partir de imagens geradas no processo de escrita autobiográfica. São 
contos que emergem como caixas fechadas na imensidão do oceano, que se tenta resgatar durante o capturar dos peixeslembranças. É a caixa de Pandora, que emergiu do mar enquanto buscava respostas para as perguntas do quem sou ou do como cheguei aqui.

Assim como Pandora, abri a caixa na tentativa de tentar encontrar respostas para um enigma. A caixa era um universo inteiro e desconhecido, um buraco negro de representações de um mundo integralmente íntimo, porém, até então desconhecido. Era o real não dado nas memórias resgatadas pelo consciente.

“A realidade não é para o homem, uma experiência imediata, mas presa a vários fios que tecem o universo simbólico ao qual está inserido e que o determina, que é configurado pelo homem e o configura (...) O homo simbolicus expressa, portanto, a mediação das formas simbólicas (arte, linguagem, religião etc) na atribuição de sentidos, o que faz com que a realidade não seja oposta ao imaginário, mas formulada, compreendida e expressa pela mediação dos símbolos”. (Ferreira-Santos e Almeida, 2012, p. 30)

Assim, os contos de Alice assumem o papel de mediadores entre a realidade vivida em memória e no imaginário, por meio da criação de imagens que constelam numa jornada simbólica de busca por saber-se quem é. Fez-se assim, duas vidas paralelas que buscam o sentido da própria existência; uma da vida real da maneira como foi possível rememorá-la no papel e outra do imaginário simbólico nascido da própria experiência do imaginar-se na vida. 


\section{2 - Entre mundos - as ressonâncias entre a vida real e imaginada}

Olhando de cima do barco fui sendo preenchida de imagens do fundo do mar. Não podia ver nada, só mesmo, imaginar. Tomei coragem, vesti o escafandro e pulei no mais profundo oceano. Fui descendo e descendo até conseguir pôr os pés no chão. Vi outro mundo. Este outro mundo era o mundo de Alice, que nesta tese teve um papel fundamental para compreensão da minha busca por saber-me mais de mim.

Nesse profundo do mar, vi coisas inimagináveis. Quando conheci Alice, não pude defini-la. Era um misto de borboleta e gente, mas tinha força de uma guerreira selvagem e a segurança e fragilidade de uma velha do mato. No mundo de Alice, havia cachorro de dentes gigantes, dragões pequenos e grandes, meninos contadores de estórias, brincalhões e espertos; meninas princesas, fadas, sátiros, florestas encantadas e bosques sombrios. Tinha Sol, muito Sol. Quase não havia noite no mundo de Alice. E no mundo de Alice era quase tudo muito seco. Pouca água... Nesse profundo do mais fundo do meu mar, quase não tinha água nenhuma.

A descoberta do mundo de Alice se deu dessa forma. Em algum momento da escrita, sem que houvesse algum planejamento ou método de escolha para a escrita dos contos, de repente, eu começava a imaginar um conto de fadas para recontar o que já havia escrito sobre a vida real. Não houve nenhum estudo para a escolha dos personagens. Entreguei a escrita para a mente infantil e, como uma criança, ia escrevendo o conto, como se pintasse um desenho sobre uma estória ouvida. 
Essa forma espontânea de lidar com o acaso das imagens criadas trouxe a oportunidade de compreender um pouco sobre o mito que me tocava, ou os mitos que regiam a minha vida.

Essa não racionalidade da criação imagética tornou a estória de Alice muito fiel e honesta aos processos que internamente se davam nessa busca por me compreender e me encontrar. Segundo Campbell (2012, p. 04) os mitos

\footnotetext{
"tem a ver com os profundos problemas interiores, com os profundos mistérios, com os profundos limiares da travessia, e se você não souber o que dizem os sinais ao longo do caminho, terá de produzi-los por sua conta”.
}

Os contos de Alice são uma revelação neste sentido. Eu estava muito afastada da "literatura do espírito" como trata Campbell (2012, p. 03) sobre os assuntos da vida interior. Vivia imersa no mundo do trabalho e da universidade, correndo com prazos e sempre muito preocupada em cumprir metas: publicar artigos, ter mais salários, orientar TCCs, escrever mais artigos, publicar e enriquecer meu Currículo Lattes.

A vida interior estava abandonada. Minha curiosidade pelas religiões que me levaram à frequentar igrejas católicas, mesas brancas, templos Hare Krishna, retiros budistas, centros de meditação, umbanda... havia sido suprimida. Eu era uma antropóloga das religiões; caminhava entre ritos e rituais tentando descobrir-me em cada um deles. Uma antropóloga de mim, não de gabinete. Era tudo pesquisa sobre mim mesma. O mestrado, de alguma forma, me afastou dessas buscas e fui me tornando muito fria e desmotivada da busca por este eu-maior que eu sabia estar dentro. Fui consumida pela ideia do egomaior, fui querendo buscar-me grande em títulos, em reverências, em status social. 
Os contos de Alice são então um retrato deste mundo interno. É criação do meu próprio mito, influenciado pelos mitos que já habitavam em mim. Campbell (2012, p. 05) diz sobre os mitos

"são histórias de nossa busca da verdade, de sentido, de significações, através dos tempos. Todos nós precisamos contar nossa história, compreender nossa história. Todos nós precisamos compreender a morte e enfrentar a morte, e todos nós precisamos de ajuda em nossa passagem do nascimento à vida e depois à morte. Precisamos que a vida tenha significação, precisamos tocar o eterno, compreender o misterioso, descobrir o que somos".

A escrita de Alice como produto da escrita autobiográfica foi revelando mitos ou estágios do monomito (Campbell, 1997) na busca pelo eu interior (self) a partir de acontecimentos cotidianos, passagens da vida, experiências que eu podia contar como um ocorrido ou das memórias afetivas, nunca sobre como cada uma destas vivências ressoavam no meu inconsciente. Alice foi isto: o resgate das memórias no inconsciente que produziram imagens que se traduziam em símbolos e arquétipos, como a vida havia sido vivida em meu interior. Ou, como reverberavam no meu presente interior. Campbell nos diz que

"estamos procurando uma maneira de estarmos vivos, de modo que nossas experiências de vida, no plano puramente físico, tenham ressonância no interior do nosso ser e de nossa realidade mais íntimos, de modo que realmente sintamos o enlevo de estar vivos. É disso que trata, afinal, e é o que as pistas nos ajudam a procurar, dentro de nós mesmos”. (Campbell, 2012, p. 05)

Rosito e Saggese (2010) desenvolveram um belíssimo trabalho com um método muito parecido com o que foi utilizado nesta tese. Apesar de não ter sido uma base teórica para o processo, durante a escrita dos contos foi uma referência importante de análise sobre como outras pessoas passam por esta experiência; experiência esta de produzir conteúdo 
imaginário a partir da escrita autobiográfica. O trabalho se baseia na produção de imagens livres a partir da escrita de trechos autobiográficos significativos para a pessoa, que, nesse caso, são professores em formação. Estas imagens, ao final do processo, são costuradas em uma colcha de retalhos.

As autoras partem da teoria da "pedagogia imaginal". que pressupõem métodos que possibilitem "caminhar entre o inconsciente e conscientização, compreendida a partir de Hillman, a aquisição de um saber pela experiência imaginativa" (p. 141). As autoras utilizam, portanto, as histórias de vida como base para produção de imagens livres, que em um longo processo formam um conjunto imagético que narra a vida do professor, de onde se torna possível extrair o mito pessoal, transformando um simples relato em uma experiência estética e "extraordinária", como colocado pelas próprias autoras. "Isto reorganiza a identidade humana" (Rosito e Saggese, 2010, p. 142).

Segundo as autoras, este processo de entrar em contato com as memórias, organizá-las, construir uma história onde possam registrar este material, possibilitam que o sujeito se aproprie da condição de autor da obra, ou o que eu chamo da vida em obra, deste transformar a própria vida em obra a ser vivida. Rosito (2009), complementa essa reflexão:

“Ao fazer uma leitura de Santo Agostinho isso me levou à confirmação de que reconhecer a autoria que nos habita é a epifania de um mistério humano. Para Agostinho, a beleza está na fruição da parte no todo, naquilo que une e arrebata os sentidos da audição, visão, olfato e tato que são atingidos pela beleza interior. A narrativa, com um valor estético, percebe a singularidade tramada na pluralidade, que emerge não da racionalidade instrumental, fora de si, mas do imaginário (Rosito, 2009, p. 494). 
Ainda durante a escrita, percebi que os contos de Alice nasciam em momentos especiais. Esse "aleatório" estava ligado aos momentos de significado especial na vida; momentos de grandes conquistas, ou de grandes perdas, tristezas, angustias, que Josso (2002, p. 495) chama de "momentos charneiras, divisores de águas", onde há "movimento para uma compreensão que libera criatividade em nossos contextos de mutação sociais e culturais”. Ou seja, são estes os momentos, que, transformados em imagens, dão sentido ao itinerário de formação, ou no simbólico, à jornada do herói. Eles correspondem às etapas, aos processos pelos quais passamos internamente na busca pelo resgate de nós. Como diz Campbell:

"É assim que se alguém - em qualquer sociedade - assumir por si mesmo a tarefa de fazer a perigosa jornada na escuridão, por meio da descida, intencional ou voluntária, aos tortuosos caminhos do seu próprio labirinto espiritual, logo se verá numa passagem de figuras simbólicas (podendo qualquer delas devorálo). Trata-se do processo de dissolução, transcendência ou transmutação das imagens infantis do nosso passado pessoal" (Campbell, 1997,p. 105).

Durante a escrita dos contos, por vezes, vinham imagens de livros, filmes, animações que por alguma razão, pareciam dar voz para aquilo que eu desejava falar. Eram os mitos internalizados e que ecoavam quando eu constelava uma imagem interna que representasse simbolicamente o que eu havia vivido na vida objetiva e real. Alguns ficaram muito marcados: a própria Alice, que sem dúvida é inspirada na Alice de L. Carroll. Foi sem dúvida, um dos livros mais incríveis que já li e, durante a leitura, me via Alice em muitas situações; como a que era ora grande, ora pequena demais, ou a da queda do buraco que a leva para um outro mundo. 
Um pouco da Alice de Carroll reverberava em minha Alice, porém uma não substituía a outra. Meu drama, meu enigma, estava em outro lugar e o fui construindo com partes soltas que haviam em mim. Usei como referência a releitura moderna de Rapunzel, na animação “Enrolados”. Dali, saiu a inspiração para Castigo, que na princesa da estória, é um camaleão que a acompanha em toda sua aventura. Mas meu Castigo tem outras características e assim, foi surgindo um novo mito. Esses "fragmentos" são mitemas que vão surgindo na narrativa de Alice. "O mito decompõem-se em alguns "mitemas" indispensáveis que lhe conferem sincronicamente o sentido arquetípico, mas diacronicamente, ele é apenas constituído pelas lições" (Durand, 1998, p.155)

Assim, Alice foi uma experiência incrível de criação e análise, que trouxe a possibilidade da descoberta da minha heroína interior, que cumpriu sua função de levar-me ao mais profundo de mim, que provocou o avanço espiritual necessário para que eu pudesse me reconhecer enquanto pessoa e retomar o caminho da busca do eu-maior, da alma.

\section{3 - A busca pelo self - a jornada pelo mundo inferior}

Durante as análises dos contos de Alice, procurei, primeiramente, entender os símbolos e arquétipos que os constituíam. Posteriormente, as análises foram ficando mais complexas e as aventuras de Alice foram nos mostrando etapas do retorno ao self ou da busca de si mesmo. Para a compreensão desse processo, utilizamos duas bases, tendo como principal 
referência a obra "As mulheres que correm com os lobos" (1999) da autora Clarissa Estés.

A análise mais profunda sobre o conjunto constituído pelos contos e que representam a jornada de uma vida foi feita sob a proposta de estudo que Estés faz sobre a estória "A donzela sem mãos", que em seu entendimento "fornece material para todo o processo da vida da mulher. Ela trata da maioria das principais jornadas da psique da mulher" (p.289). Ao contrário do que fizemos ao longo da escrita da tese, que foi a busca da compreensão de etapas ou fases de aprendizados e tarefas específicas desta busca do si-mesmo.

As histórias e estórias que ouvimos reverberam em nossa alma como reflexos do espelho que, ao amanhecer, buscamos nos ver para termos certeza de quem somos ou de quem queremos parecer antes de sair para o mundo. Nem sempre as estórias ecoam porque nem sempre estamos preparados para ouvi-las. Mas elas ficam guardadas em algum lugar de nós para que talvez possamos acessá-las no momento certo.

Alice traz algo diferente, um acréscimo a este ouvir do outro que está fora. Alice foi uma voz de algo interno. A alma soprou a vida de Alice nos meus ouvidos. Ouvi a voz interior me contando uma estória sobre alguém que vivia em um outro mundo, um mundo interior, que nem eu mesma sabia existir. Neste caso, não foi "mística da participação", como se referem os junguianos a este relacionamento, no qual "a pessoa não consegue se distinguir como entidade separada do objeto observado" (p.287).

No processo de escrita de Alice, houve um movimento reverso, foi preciso me separar do objeto que estava integrado a 
mim, para que pudesse observá-lo. Foi uma narrativa que seguiu caminho inverso. Da alma para o ouvido, do ouvido para o coração. No entanto, o resultado foi o mesmo: o de desenvolver a “capacidade da mente de se afastar do seu ego por um tempo e se fundir com uma outra realidade, ali vivenciando e aprendendo ideias que ela não pode aprender em nenhuma outra forma de consciência para depois trazê-las de volta à realidade consensual" (p.287)

É preciso esclarecer que o estudo da jornada de Alice se faz agora sob uma outra ótica. Se antes relacionei cada conto à um trecho autobiográfico ao qual estava ligado, agora nossa tentativa será de entender toda a estória como produto de representação simbólica do resgate de minhas memórias. Alice não é mais um conjunto de partes, Alice agora é uma, é uno. Alice é um caminho percorrido com experiências vividas, encontros, desencontros, perdas e ganhos. Alice sou eu neste momento da vida. Alice e os personagens dos contos de Alice sou eu e todos os arquétipos que constelam em mim: "consideramos todos os elementos de um conto de fadas como descrições de aspectos da psique de uma única mulher”. (Estés, 1999, p. 294)

Durante o resgate e escrita das memórias, fui descendo às profundezas da psique e as Alices trouxeram mais do que memórias do vivido, trouxeram memórias inconscientes, memórias de afetos, sensações; trouxeram a imagem das forjas onde foram fundidas e moldadas as estruturas que alicerçaram a construção do eu-persona e do desconhecido do eu-interior. Assim, trabalharemos sobre Alice como a jornada de uma mulher na busca pelo selvagem feminino.

O mito "A donzela sem mãos", escolhida por Estés como um exemplo de estória onde estão presentes todas as fases da 
jornada feminina de busca (ou retorno) pelo self, traz a resistência como marca para a sobrevivência da mulher nessa jornada. Estés nos diz:

"O termo resistir dá a impressão de significar 'continuar sem interrupção' e, embora essa seja uma parte eventual das tarefas subjacentes ao conto, esse termo também significa 'endurecer, tornar firme, robusto, fortalecer'. É esse o principal impacto do conto bem como a característica produtiva da longa vida psíquica da mulher. Não continuamos só por continuar. A resistência denota que estamos criando algo. $\mathrm{O}$ ensino da resistência ocorre em toda a natureza (p. 289-290).

Alice é uma personagem que resiste. Desde o seu nascimento, na infância, juventude e vida adulta, Alice está sempre buscando sobreviver. Alice é resiliente. Não há tarefas que não cumpra e nem obstáculos que a façam parar. Ela é andarilha, não tem pouso, não tem parada. Alice está sempre a caminhar.

Alice, assim como a donzela do conto, realiza algumas descidas que levam à transformação. Estas descidas são momentos em que Alice adentra bosques escuros e pantanosos, florestas de magia, anda por caminhos desconhecidos ou entra num buraco de rã. São representações de "estágios alquímicos" (p.289) que em Alice se completam com o encontro ou o resgate com a Luz.

Os contos de Alice trazem vários personagens, mas dois a acompanham durante quase toda a jornada - o cachorro Castigo e o dragão, que também sofrem mudanças decorrentes das "descidas" de Alice. Tentaremos compreender qual a representação embutida nestas imagens que constelam na composição do ser-Alice. 
A análise proposta por Estés (1999) é feita a partir da identificação de sete estágios alquímicos, os quais constituem etapas ou fases desta busca pelo feminino selvagem.

\section{1 - O primeiro estágio - o pacto sem o conhecimento}

No primeiro estágio, há a identificação de um "pacto infeliz", onde algo é renunciado em função do ganho de um "algo de mais valor", que Estés explica ser o momento em que "entregamos nossa natureza selvagem em troca da promessa de algo que parece rico mas que se revela vazio" (p.294).

$\mathrm{Na}$ estória estudada por Estés, um lenhador recebe a visita do diabo, que oferece riqueza em troca do que está atrás do lenhador. Ao olhar para trás, o homem vê uma macieira e aceita a troca. Assim que o diabo se afasta, a esposa do lenhador vem lhe perguntar sobre as mudanças que notou em sua casa, que havia se transformado em uma luxuosa mansão. O lenhador conta sobre o pacto com o diabo e sua mulher vê atrás da macieira a filha do casal. Eles entendem que, na verdade, o que foi trocado com o diabo foi sua própria filha e não a macieira.

No conto "O dragão e a menina Alice", o homem bom prende a lagarta com fios de seda para distrair o dragão e poder fugir para o mundo dos homens. O dragão fica furioso com a lagarta e a leva para sua caverna. "Nunca mais a lagarta teria paz... nunca mais o dragão teria brilho no olhar”. Está feito o pacto infeliz e desconhecido.

Alice teria nascido borboleta, não fosse o fato de ter tido problemas na “digestão” enquanto ainda era uma lagarta. Sem 
saber o que acontecia ao seu redor, Alice foi vítima de uma relação entre o homem bom e o dragão. Não foi escolha de Alice fazer parte da situação, nem mesmo distrair o Dragão com suas músicas de Malpighi. Era de sua natureza viver lagarta e se transformar em borboleta para voar.

Ao ser levada pela lagarta, em um ato cruel do homem bom, Alice se viu presa em uma estória da qual não podia escapar. Ela estava presa em fios de seda e, logo, nas garras do dragão. O homem trocou Alice pela sua liberdade; deu Alice ao dragão, que furioso, tirou de Alice a possibilidade de nascer borboleta - de voar, de viver sua natureza selvagem.

A lagarta estava ali a fazer a digestão e poderia ter continuado sua vida como uma larva que logo se desenvolve e, por meio de seu próprio metabolismo, alcança sua metamorfose completa. Há vida, há digestão, há metabolismo, há processos internos vitais acontecendo. Na vida, “digerimos” psiquicamente as experiências pelas quais passamos, de forma a assimilá-las melhor, transformando em nutriente para alma o que pode ser aproveitado e expelindo o que não pode.

\footnotetext{
“a psique é um triturador de idéias. Ela mastiga os conceitos e os desdobra em alimento. Ela recebe a matéria-prima, sob a forma de idéias, sentimentos, pensamentos e percepções, e a decompõe de modo a torná-la útil para nossa nutrição. Essa capacidade psíquica é muitas vezes chamada de processamento. Quando processamos, selecionamos toda a matéria-prima da psique, tudo o que aprendemos, ouvimos, desejamos e sentimos durante um determinado período. Decompomos tudo isso, perguntando, 'Como posso fazer o melhor uso disso?' Empregamos, então, essas idéias e energias processadas para implementar nossas tarefas mais profundas e para sustentar nossas diversas iniciativas criativas. Desse modo, a mulher se mantém robusta e ativa" (p. 295)
}

Na lagarta, este processo é interrompido. Fica falho. A digestão que seria o processamento da psique fica comprometido 
e Alice nasce outra coisa que não era a sua própria natureza. Isso quer dizer que nada está sendo feito com toda a matéria prima que entra na nossa vida diariamente e que não está sendo obtida nenhuma compreensão a respeito dos grãos de conhecimento do mundo real e do mundo oculto que atingem o nosso rosto. (p. 295-296)

Quanto ao papel do "homem bom", durante a escrita deste conto, busquei representar na estória a informação que tinha sobre meu próprio nascimento. A figura desse homem é análoga à figura do pai no conto da "Donzela sem mãos": "que simboliza a função da psique que deveria nos orientar no mundo objetivo, (...) o ideal coletivo que pressiona as mulheres a serem murchas em vez de exuberantemente selvagens"(p. 295; 299). Simbolicamente, esse sofrimento interno não foi bem processado pela psique, que passa agora a agir em função das forças externas representadas pelo meio social, prejudicando assim o desenvolvimento saudável da vida interior.

Segundo Estés (1999), o desenvolvimento desse terrível pacto envolve um paradoxo enorme e significativo.

"Apesar de a escolha infeliz poder ser considerada uma reação autodestrutiva em termos psicológicos, é muito mais frequente que ela se torne um divisor de águas, um evento que proporciona ampla oportunidade para a restauração da força da natureza instintiva. Nesse sentido, embora haja tristeza e perda, o pacto infeliz, como o nascimento e a morte, constitui um passo utilitário fora do penhasco planejado pelo Self com o objetivo de mergulhar a mulher profundamente na sua natureza selvagem. A iniciação da mulher começa com o pacto infeliz que ela fez há muito tempo enquanto ainda estava entorpecida. Ao escolher aquilo que a atraiu como sendo a riqueza, ela cedeu, em troca, seu domínio sobre algumas partes, e muitas vezes sobre todas as partes, da sua vida instintiva, criativa e cheia de paixão. Esse entorpecimento psíquico feminino é um estado próximo ao sonambulismo. Durante sua vigência, andamos, conversamos e no entanto estamos dormindo. Amamos, trabalhamos, mas nossas escolhas revelam a verdade acerca da nossa condição" (p. 294). 
Alice passa a viver suportando as agressões do dragão. Alice poderia ter fugido ou mesmo ter enfrentado o dragão e lutado pela sua liberdade, mas não o fez. Ela era parte do pacto feito entre o dragão e o "homem bom". Alice suportaria qualquer coisa em nome desse amor. Desde muito pequena havia em mim uma preocupação em atender as expectativas alheias, em ser uma menina boa, em ser submissa, em "aguentar qualquer coisa"; o que ao mesmo tempo, me fazia sentir inadequada, inferior e presa a algo que nunca soube dar nome. A partir desse pacto, passo a buscar por algo perdido, pela minha natureza selvagem, pelas partes perdidas de mim nessa metamorfose incompleta de lagarta a borboleta.

Estés ainda menciona esse "sono" que também aparece no conto "As asas de Alice", no trecho: "Por vezes, Alice não tinha forças para levantar... Chorava até desmaiar. Seu sono a tirava da dor". Passei quase toda a vida procurando despertar e enquanto dormia, só conseguia reproduzir o pacto infeliz encontrar um "homem bom" que me trouxesse a liberdade de volta. Fato que fica evidente nos inúmeros relacionamentos abusivos que vivi ao longo da minha história. Pessoas que me prendiam em fios de seda, em troca de sua própria liberdade, deixando o dragão ainda mais furioso,

"quando a mulher renuncia aos seus instintos que lhe indicam a hora certa para dizer sim ou não, quando ela renuncia ao seu insight, sua intuição e outros traços de natureza selvagem, ela se encontra, então, em situações que prometem ouro mas que acabam gerando dor" (p. 296).

É preciso estar desperto para encontrar o que nos foi arrancado para resgatar o que verdadeiramente somos. 
Baseando-se na leitura de Estés sobre o conto da "Donzela sem mão", o dragão seria análogo ao diabo que simboliza " $a$ força sinistra da psique, o predador" (p. 296), enquanto que Alice é análoga à donzela, que representa o próprio self feminino.

Em vários contos, mitos, lendas e estórias populares é comum a presença de personagens que representem a "mãe selvagem", que eu, particularmente, dou o nome de Baba Yaga, personagem da estória de Vasalisa que tocou meu coração. Busquei em todos os contos de Alice, esse arquétipo, porém, o mais próximo que consegui chegar de uma leitura nesse sentido, foi a "grande árvore" do conto "Alice e o velho preto de Luz", já no fim da jornada de Alice.

A “mãe selvagem” é “assustadora por ser ela própria o poder da aniquilação e o poder da força da vida ao mesmo tempo" (p. 70). Assim, entendo que o dragão também constela na atuação desse elemento da psique. Ele é a Baba Yaga de Alice, a representação da ligação de Alice com o ventre, com a terra, com as profundezas e penhascos do inconsciente.

\section{2 - O segundo estágio - a mutilação}

Para Estés, o segundo estágio de busca pelo próprio self ou pela natureza selvagem feminina é "a mutilação", momento em que a mulher representada nos contos e mitos sofre algum dano físico que promova cortes ou perda de partes do corpo. $\mathrm{Na}$ estória estudada por Estés, a donzela perde suas mãos, amputadas pelo próprio pai, em decorrência do pacto feito com o diabo. Antes desse episódio, a donzela, que espera o diabo do 
lado de fora de sua casa, vai adquirindo com o passar dos dias um aspecto animalesco, sujo, degenerado.

Ao buscar em Alice alguma passagem que se relacionasse a este estágio, encontrei no conto "Alice e o homem sem face" uma mutilação. Alice, depois do encontro com o homem, sai do pântano escuro com uma cicatriz nas mãos.

Este conto traz muitas relações com esse estágio da estória da “Donzela sem mãos". Alice é levada ao pântano pelo dragão, e apesar de não querer se submeter à situação em que é colocada, ela não vê escolha e acredita precisar sofrer a violência que lhe é imposta como prova de amor.

"Ficamos entorpecidas quando passamos por esse estágio e percebemos o que nos foi feito, como cedemos diante da vontade do predador e do pai apavorado de tal forma que acabamos mutiladas" (p. 299).

No conto de Alice é descrito que ela caminha por um pântano lodoso e fétido que suja seus sapatos, roupas e meias. Há dificuldade em caminhar e não há luz. Alice está imersa na escuridão. Como no conto da donzela.

"Ela começa, então, a se parecer com uma força animal, com a natureza selvagem subjacente, e isso também é uma proteção. $\mathrm{O}$ predador deseja degradá-la, enfraquecê-la com suas proibições. O diabo acha que, se a donzela não tomar banho e ficar imunda, ele poderá roubá-la de si mesma. O que acontece, porém, é exatamente o contrário, pois a mulher suja de fuligem, a mulher de lama, é amada pela Mulher Selvagem e inequivocamente protegida por ela" (p. 302).

Alice, antes do encontro com o "homem sem face", está toda suja e enlameada. Alice está protegida.

Alice, no conto, dá as mãos a esse homem em quem, mesmo sem saber quem é, confia. Esse masculino, representado talvez sob a ótica de um pai, aquele que aparece no caminho escuro e oferece proteção. O pai que simboliza o mundo 
concreto, o meio social, o masculino interno. Há em Alice a expectativa de que possa caminhar sob esse olhar, que julga cuidadoso.

"Pensamos que nossos constructos paternos interiores deveriam estar sempre alerta, solidárias com a psique em flor e protetoras para com ela (...) Descobrimos agora o que acontece quando elas não estão".(p. 299)

No fim do conto, Alice está caída ao lado de uma pedra, não se lembra do que houve, mas sente ódio pelo dragão que, no seu entendimento, deveria proteger-lhe. Alice sobreviveu. Porém, carregará para sempre uma cicatriz em sua mão. Comparado ao conto da donzela,

"O objetivo do diabo é o de fazer com que a donzela perca as mãos - ou seja, sua capacidade psíquica de apreender, de segurar, de ajudar a si mesma ou aos outros. (...) A filha submetese à mutilação, e o sacrifício de sangue é realizado, aquilo que nos tempos antigos indicava uma descida total até o mundo subterrâneo. Com a perda das mãos, a mulher abre caminho para entrar na selva subterrânea, o campo de iniciação do mundo oculto. Nesse instante a inocência da mulher foi assassinada, sem poder jamais voltar a ser o que era antes (p. 302).

Escrever sobre esse episódio da vida causou em mim muita dor, mas foi preciso o resgate para entender o que representa essa experiência na vida que construí, na pessoa que busquei ser. De alguma forma, sentia raiva por não ter sido protegida pelos meus cuidadores, mas sentia, também, culpa pela situação. Como o que é descrito por Estés, nos culpamos por compactuar com tamanha agressão a que nos submetemos. A cicatriz nas mãos de Alice simboliza, de certa forma, uma mutilação na psique que permanece em função desse trauma e, mais importante, o resultado da agressão.

Muitos foram os momentos na vida em que esperei passivamente por um "pai" que viesse me proteger, que viesse me 
salvar e conduzir pelo pântano lodoso, dando as mãos, quase que invariavelmente, a qualquer estranho sem face que me aparecesse no caminho. Abri mão de buscar-me em minha essência, de reconhecer minha natureza selvagem por permanecer no bosque lodoso.

Sei apenas que nunca deixei de buscar, de descer, mesmo de forma entorpecida. "Com esse corpo incorpóreo e estranho, vamos adiante. Estamos a ponto de realizar a descida seguinte"(p. 306).

\section{3 - O terceiro estágio - a perambulação}

O terceiro estágio de busca é o da "perambulação". Neste estágio, a mulher da estória resolve, mesmo ferida ou amputada, seguir seu caminho de busca sozinha. Sem levar nada ou ninguém em que possa se apoiar, ela parte caminhando em busca do seu próprio destino. É o afastamento do mundo comum ou o início do processo de iniciação da "jornada do herói” (Campbell, 1997).

A iniciação é o processo pelo qual desistimos da nossa inclinação natural para permanecer inconsciente e resolvemos que, custe o que custar - sofrimento, luta, persistência -, iremos perseguir a união consciente com a mente mais profunda, o self selvagem (Estés, 1999, p. 306)

Consideramos, durante as análises dos contos separados da jornada de Alice, que o convite para a iniciação se deu no conto "Alice e o Sátiro". Porém, seguindo os estágios propostos por Estés, podemos inferir que o processo de iniciação se dá no conto "Alice e as princesas", no qual Alice assume que quer ser 
algo além do que tem sido, quando deixa de lado aquele "destino" imposto e busca assumir um papel por ela escolhido para sua vida.

Alice passa por um exílio, antes de começar sua perambulação e tomar a postura de tornar-se "princesa de si mesmo". No conto "Alice e o mundo atrás do espelho", Alice é ludibriada pelo dragão que a leva e a abandona em outro mundo. Antes de se preparar para sair em busca do seu próprio destino, Alice enfrenta sozinha um mundo de perigos e solidão e, no conto "Alice, os sapos e a solidão", há ainda um desejo manifesto de Alice em se tornar sapo, em se tornar comum, em se tornar aquilo que não é como intenção de deixar a vida mais fácil. Se comparado ao conto da donzela, seria o momento em que se espera que ela abandone projetos maiores, já que está tão debilitada.

"Irá ela se recolher, ferida e sem mãos, para os recessos da
psique, onde possa receber atenções pelo resto da vida, deixando-
se levar e fazendo o que lhe ordenam? Não, ela não vai se
esconder para sempre num quarto escuro como faria uma
beldade deformada pelo ácido. Ela irá vestir-se, medicar-se em
termos psíquicos da melhor maneira possível e descer mais um
degrau de pedra que a levará a um reino ainda mais profundo da
psique. A antiga parte dominante da psique oferece-lhe a
possibilidade de mantê-la escondida e em segurança para
sempre, mas sua natureza instintual recusa o oferecimento, pois
sente que precisa lutar para viver em plena consciência, custe o
que custar" (p.306).

Assim, como a donzela, Alice decide voltar para casa e se preparar para a grande jornada. "Alice se fez princesa. Sozinha em casa, pegou uma lata de leite condensado, tirou todo o leite e só deixou o doce grudado no flandres. Com uma tesoura bem forte, recortou sua coroa. As meninas nunca saberiam que Alice era princesa de si mesmo... Não tinha Reino , não tinha Castelo, 
não tinha Rei, nem Rainha... Alice só tinha Castigo e um dragão. Ao dragão ela deu nome de Rainha e a Castigo, ela deu o nome Cachorro".

Depois deste conto, Alice parte a caminhar e, em seguida, recebe o convite para sua efetiva iniciação no encontro com o Sátiro. Na vida real, a passagem da infância para a adolescência - vida-morte-vida. Alice, assim como a donzela, é agora andarilha: "O arquétipo do andarilho propicia ou causa o surgimento de um outro: o do lobo solitário ou do proscrito (...) Agora, porém, seu velho self não mais existe, e o self profundo, o self nu, é o poderoso andarilho" (p. 307-308).

Em suas andanças, Alice prossegue passando por diversas aventuras, superando obstáculos, criando vínculos, sendo acolhida. Convive com criaturas mágicas, aprende, sofre, seduz e é seduzida pela vida. Podemos considerar que na iniciação de Alice há duas fases, assim constituídas: a primeira fase do caminho iniciatório, quando Alice passa por provas e chega à escola de bruxas, lá é acolhida por meninas-bruxas e juntas vão morar na "copa da árvore mais alta do bosque". Alice também se encontra com insetos cantadores que são levados para uma grande "festa de luz" nessa morada. São os acolhimentos da psique selvagem, que garantem aprendizado e a possibilidade de sobreviver à descida em busca de si.

“A mitologia grega é fértil em relatos de jovens sendo acompanhadas por mulheres-lobas, mulheres-leoas ou outras criaturas que serviam como suas iniciadoras. A ideia psíquica aqui representada é a de que o mundo subterrâneo, à semelhança do inconsciente dos seres humanos, é um torvelinho com muitas características incomuns e irresistíveis: imagens, arquétipos, seduções, ameaças, torturas e provas” (p. 308) 
A "árvore mais alta do bosque" é a mãe selvagem. A ligação entre Alice e as meninas-bruxas que estão intimamente ligadas ao ventre da terra e em ascensão. Faço um paralelo com a vida real: na autobiografia estávamos, nós meninas-mulheres, nos acolhendo como uma matilha de lobas, mas com o objetivo maior de terminar a graduação - a busca do saber do mundo objetivo. Daí essa dualidade tão bem representada em Alice, A “árvore mais alta” é também a de raízes mais profundas e a morada das meninas-bruxas foi feita na copa dessa árvore. A busca pelo céu, pela conquista do mundo real, porém em profunda comunhão com o mundo inferior. Analogamente no estudo da estória da donzela:

"Na história, a ação está agora centrada na árvore frutífera, que em tempos remotos era chamada de Árvore da Vida, Árvore do Conhecimento, Árvore da Vida e da Morte ou Árvore do Saber. Ao contrário de árvores com folhagens diversas, a árvore frutífera é uma árvore de alimento abundante - e não só de alimento, pois a árvore armazena água nos seus frutos. A água, o líquido fundamental do crescimento e da continuidade, é absorvida pelas raízes que alimentam a planta pela ação capilar - uma rede de bilhões de ligações celulares pequenas demais para serem vistas - e a água chega até o fruto e faz com que ele cresça e se embeleze. As mulheres que se alimentam do fruto, da água e da semente do trabalho nas florestas do outro mundo também crescem psicologicamente na mesma proporção" (p.309).

A escola de bruxas e a morada Biomba foram o momento de descanso e preparo para a jornada individual. Depois de fortalecida e alimentada pela música na festa dos insetos cantadores Alice parte sem saber para onde levaria seu destino. No caminho encontra seu primeiro guia - "velho homem sábio", aquele que a conduzirá ao encontro com seu Presente. Alice, que até então vivia em um mundo ainda sem tempo marcado, sem relógio, sem hoje ou sem amanhã, tem agora que conviver e cuidar do seu Presente - o tempo vivido na condição do real. 
Alice assume uma responsabilidade eterna, a de cuidar do seu próprio tempo-Presente.

Este foi o encontro com Matheus, meu mestre na orientação dos estudos, das práticas do conhecimento, da responsabilidade sobre o cuidar do saber com o coração, sobre o não desistir dos sonhos e continuar a perambulação:

"guias espirituais são sempre designados para os jovens iniciandos (...) É importante para o processo de individuação da mulher que ela tenha bom senso espiritual, ou que seja auxiliada por um guia que o tenha, para que ela não caia na fantasmagoria do inconsciente, para que ela não se perca no meio desse material torturante e sedutor" (p. 308-309).

Alice parte de volta à perambulação, caminha ainda em busca de si, mas resolve fazer outra parada. Mais um momento de descanso e preparo. Alice em "Alice e as trevas" parece ter se acomodado em algum estágio de busca. Ela monta morada próximo a um lago calmo, onde poderá cuidar do seu Presente. Porém, algo tenebroso acontece: os dias viram noites. Alice se vê consumida sem luz e parte em busca do seu Sol perdido.

Esta parece ser a fase de entrega. A mulher da estória se cansa de perambular, aceita o destino que lhe foi dado e parte para viver com o que conquistou. Um momento de acomodação que no mundo objetivo seria aquele em que as mulheres desistem de seus sonhos e passam a viver conformadas com a vida que conseguiram construir para si. “(...) aquela sensação de repouso e realização que pode seduzir os humanos a considerarem que um feito espiritual ou o término de um ciclo espiritual seja um ponto em que podem parar e descansar sobre os louros para todo o sempre" (p. 314). No entanto, o self selvagem se manifesta e quebra a monotonia da felicidade bucólica de Alice para que ela volte ao seu caminho de busca. 
Para reconquistar seu Sol, sua fonte de vitalidade, Alice sai sozinha e cai em um buraco de rã. Alice ficou tão pequena, seu self selvagem foi tão diminuído, que um buraco de rã lhe pareceu um "buraco sem fim". Alice caiu até ver seu Sol e com toda força que pôde, o trouxe de volta para o lugar certo, para dentro si. Alice volta a caminhar até encontrar seu segundo guia "embaixo de uma enorme árvore”. Estés traz esta interpretação para o conto da Donzela, que é análoga a essa passagem de Alice:

\begin{abstract}
"A história ressuscita nosso conhecimento de uma promessa muito antiga; a promessa de que a descida nos será benéfica mesmo que esteja escuro, mesmo que tenhamos a impressão de estar perdidas. Mesmo em meio à falta de conhecimento, à falta de visão, quando estamos 'vagueando às cegas', existe 'algo', 'alguém excessivamente presente que acompanha nosso ritmo. Agora estamos num outro nigredo em que perambulamos sem saber o que será de nós, e no entanto, nessa condição extremamente precária, somos levadas a sorver da Árvore da Vida. Selvagem, estamos comendo aquilo que nós mesmas iremos nos tornar" (p.310).
\end{abstract}

Esse guia-mestre conduzirá Alice ao próximo estágio da busca pela sua alma selvagem. Trará para Alice, a possibilidade de reconhecer guerreira. Este trecho da estória de Alice está no conto "Alice e o velho preto de luz", onde há mais uma parada para descanso e preparo para que Alice possa voltar a ser andarilha de si.

\title{
3. 4 - O quarto estágio - encontrando o amor no outro mundo
}

No quarto estágio de descida e busca pelo self selvagem, Estés cita que a mulher da estória irá ao "encontro com o amor do outro mundo". No conto analisado pela autora, a donzela parte caminhando entre a floresta, sem mãos, a donzela não pode fazer muito por si, nem mesmo se alimentar. Resta a ela 
caminhar. Durante sua perambulação, a donzela sente fome e é alimentada por uma árvore, que por meio da intervenção de um espírito da floresta, curva-se, permitindo que a donzela consiga morder o fruto.

A árvore pertence ao pomar do rei, que na manhã seguinte ao ocorrido, desce para conferir se suas peras estão no devido lugar. Ao perceber que falta uma, recorre ao jardineiro que lhe conta o fato passado. Eles então, procuram o mago, mediador entre os dois mundos, aquele que pode trazer uma resposta sobre o mundo real e o mundo dos espíritos. O rei, o jardineiro e o mago aguardam o retorno da donzela e o encontro entre o rei e a donzela acontece. $\mathrm{O}$ rei acolhe a donzela e promete se casar com ela. "O jardineiro, o rei e o mago são três personificações maduras do arquétipo do masculino" (p. 311).

No estágio anterior nos referimos ao encontro com o mestre de luz. Neste momento da estória, Alice está acompanhada por duas personificações do masculino - o mestre de luz e Presente. Falta o encontro com o rei. Porém, vamos retroceder um pouco à estória até a queda de Alice no buraco de rã.

Para chegar à árvore onde encontraria seu mestre de luz, Alice teve que vencer o medo e sair em busca do Sol, encontrando-o em um buraco de rã. Se não tivesse passado por esse obstáculo, o encontro não aconteceria. $\mathrm{Na}$ estória da donzela, é preciso que ela atravesse um fosso para que chegue ao pomar do rei e possa se alimentar e dar continuidade a sua caminhada. O fosso e o buraco de rã representam a descida ao mundo inferior, necessária descida de resgate, de busca, de contato com o que está submerso. Estés traz a seguinte leitura 


\begin{abstract}
"Quando entramos num círculo, ou o atravessamos, estamos entrando num outro estado do ser, num outro estado de consciência, ou de falta dela, ou estamos passando por esse estado. Nesse caso, a donzela está passando pelo estado de inconsciência reservado aos mortos. (...) Em virtude de ter de passar pela terra dos mortos na sua descida, a mulher às vezes fica confusa e pensa que terá de morrer. Isso, porém, não é verdade. A missão consiste em passar pela terra dos mortos como criatura viva, pois é assim que se gera consciência. Esse fosso é, portanto, um símbolo extremamente significativo (...) Não devemos nos deitar e adormecer felizes com o que já realizamos do nosso trabalho" (p. 314-315).
\end{abstract}

No caso de Alice, no início do conto "Alice e o velho preto de luz”, há um deescontentamento pela vida vazia e sem sentido. Alice percebe que precisa retomar a sua busca. Aos pés de uma "grande árvore" ela encontra seu mestre, que a orientará na busca do mundo dos seres invisíveis. Ou seja, esse não é um guia comum, que auxilia e acolhe no mundo real como seu guia anterior - o mestre sábio. Este é o mago, aquele que pode se comunicar com os dois mundos, o do visível e do invisível e viabilizará o encontro de Alice com o rei, representado pelo guerreiro, que pede que Alice o acompanhe para formar um novo bando.

Assim, temos as três personificações do masculino em Alice, representadas pelo mestre de luz, Presente e o Guerreiro. Porém, algo nos falta. A personificação do feminino ancião, a personificação da mãe selvagem e do dragão/diabo, que age como as forças perversas da psiquê.

Quando o dragão abandonou Alice, deixou de herança um cachorro preto, Castigo, revelado no conto "O Castigo de Alice". O cachorro Castigo é, na verdade, o simbolismo da ligação de Alice com sua mãe ancestral, com o seu feminino selvagem. Ele é a intuição, aquele que guia, acompanha, protege e pune. Assim, 
Castigo é a criatura do dragão (mãe selvagem)/diabo - imagem dual, reparadora e destruidora. É um pouco do dragão impregnado em Alice; é a sua Baba Yaga a acompanhando em sua jornada.

Quando Alice encontra o mestre de luz, Castigo já está velho e sem forças, representando uma intuição ligada a um self que precisa renascer. Porém, no encontro com o mestre, Alice parte para busca do novo mundo, do mundo dos que não são vistos e deixa Castigo sob os pés da "grande árvore". Castigo morre ali. Morte-vida-morte, novamente. A morte como representação da reintegração do organismo à terra. O corpo morto sobre a terra se decompõe e se transforma em alimento para a árvore. A grande árvore é também a grande mãe terra. Alice está novamente conectada às raízes. Ela está pronta para buscar seu renascimento.

"Essa é a verdadeira natureza da árvore psíquica: ela cresce, ela dá, ela se esgota, ela deixa sementes para a renovação. Ela nos ama. É assim o mistério da vida-morte-vida. Do seu ponto privilegiado, no entanto, as figuras do mundo subterrâneo nos veem como uma vida abençoada lutando com dificuldades. Segundo a visão do outro mundo, somos uma chama forte debatendo-se contra um vidro escuro para quebrá-lo, libertandose. $\mathrm{E}$ todos os elementos úteis no nosso lar subterrâneo apressam-se a nos ajudar” (p. 316).

Para que Alice possa prosseguir em sua jornada e ir ao encontro do amor do outro mundo, Alice recebe ensinamentos sobre o mundo invisível. Seu mestre a auxilia na compreensão sobre a existência e o funcionamento deste mundo e diz a ela que é preciso desenvolver poderes mágicos para enxergar o invisível no mundo. $\mathrm{O}$ mestre diz a Alice que ela se transformará em uma guerreira. É preciso que Alice abandone a ideia de "princesa de si mesmo" e aceite o novo papel que lhe é dado: 
"É legítimo dizer que esse tipo de conjunctio está insistindo numa surpreendente revisão do seu velho self (...) o irromper de uma nova vida, uma semente de uma nova identidade. $\mathrm{O}$ mundo da alma sempre aguarda o neófito e o andarilho (...) Figuras santas desde tempos imemoriais asseguram-nos de que na estrada aberta da transformação já há "um lugar a nós destinado". E até esse lugar, seja pelo faro, seja pela intuição, somos arrastadas ou nos vemos transportadas pelo destino (...). Não há como escapar. Nesse episódio, os três atributos masculinos da psique da mulher - o jardineiro, o rei e o mago são os vigias, os inquiridores e auxiliares na viagem da mulher pelo outro mundo, onde nada é como aparenta ser. O mago da psique, que tem condição de entender questões do mundo humano bem como do espiritual, que pesquisa as distinções entre os fatos psíquicos e o inconsciente" (p.314).

Alice, mesmo sem acreditar que pode assumir o papel de guerreira, aceita sua nova condição e parte mais uma vez, sozinha em sua jornada, mas desta vez, com destino certo: Alice vai em busca do mundo invisível.

Andando pela floresta escura, Alice vê luzes e pensa ser este o caminho para o mundo invisível. $\mathrm{O}$ acesso ao mundo invisível se deu pela entrada no passado; num passado anterior a sua própria existência, escrito no conto "Alice e os guerreiros de Aruanda”. Esse passado em que Alice mergulha, pode ser o resultado da escrita desta tese, onde tive que acessar as memórias anteriores a minha própria existência, lá onde Alice nem era Alice, era apenas uma lagarta.

Nesse lugar ela foi acolhida por homens e mulheres guerreiras e lá se deu o encontro com o guerreiro/rei - aquele com quem Alice faria parceria para prosseguir em sua busca.

"O rei é uma criatura que transmite sabedoria na psique do outro mundo (...) um dos principais guardiões do inconsciente da mulher (...) Como a donzela, ele é capaz de aguentar muito. E como a donzela, ele ainda tem mais uma descida à sua frente. A psique sempre acompanha de perto seu próprio processo, como uma sombra. Ela quer dizer que, se você estiver vagueando, sempre haverá mais alguém - pelo menos uma pessoa e muitas vezes mais de uma - que seja mais maduro e experiente e que 
somente espere que você bata à porta, bata na pedra, coma a pera ou simplesmente apareça, para que ele anuncie sua chegada ao mundo subterrâneo" (p. 310).

O encontro de Alice com o guerreiro traz a união dos opostos. "Alice viu neste guerreiro toda a força que sempre desejou ter, viu em seus olhos um brilho de viver e em seus pés, o chão que Alice nunca teve”.

“ (...) reunião dessas poderosas partes da psique, tanto as masculinas quanto as femininas. Elas formam um conjunctio. Esse termo pertence à alquimia e indica uma união altamente transformadora de substâncias dessemelhantes. Quando ocorre o atrito entre esses opostos, resulta daí a ativação de certos processos intrapsíquicos. Eles agem como a pederneira em atrito com alguma pedra para fazer fogo. É através da conjunção e da pressão de elementos díspares habitando o mesmo espaço psíquico que são criados o conhecimento, o insight e a energia profunda (...) Quando presenciamos uma reunião rara e preciosa como essa, sabemos que um matrimônio espiritual está iminente; sabemos também que ocorrerá uma morte espiritual e que uma nova vida surgirá. Esses fatores preveem o que está por vir" (p. 313).

O casal abandona o bando e segue acompanhado por um bebê-Desejo. É Desejo que ilumina quando eles ficam invisíveis, ou seja, ele mantém a magia para que Alice possa continuar a enxergar esse outro mundo. Sem Desejo, Alice poderia, a qualquer momento, perder seus poderes mágicos e voltar ao mundo real e visível. Desejo é a possibilidade de se manter viva no mundo subterrâneo.

$\mathrm{Na}$ autobiografia, esse foi o momento de meu encontro com Pedro, uma história quase de conto de fadas, exatamente como descreve Estés sobre como se manifesta este estágio na vida real de uma mulher:

"É frequente que a mulher nesse estado sinta um enorme entusiasmo, do tipo que a mulher sente quando encontra um companheiro extremamente parecido com aquele com quem sonhava (...)É a época em que ocorre um segundo nascimento decorrente de uma fonte mágica, e daí em diante a alma passa a 
fazer jus a duas linhagens, uma do mundo físico, outra do mundo invisível. O rei diz que irá proteger e amar a donzela. Agora a psique está mais consciente. Haverá um casamento, uma união muito interessante entre o rei vivo da terra dos mortos e a mulher sem mãos da terra dos vivos. Um casamento entre dois parceiros tão díspares certamente poria à prova o amor mais magnífico entre duas pessoas. No entanto essa união está relacionada a todos aqueles casamentos picarescos nos contos de fadas nos quais são reunidas duas vidas cheias de energia, porém dessemelhantes. A borralheira e o príncipe, a mulher e o urso, a jovem e a lua, a mulher foca e o pescador, a donzela do deserto e o coiote. A alma absorve o conhecimento de cada entidade. É isso o que quer dizer "nascer pela segunda vez". Nos casamentos dos contos de fadas, como nos do mundo objetivo, o grande amor e união entre seres diferentes pode durar para sempre, ou apenas até que o aprendizado esteja concluído. Na alquimia, a união dos opostos significa que logo ocorrerão uma morte e um nascimento" (p. 317).

Este segundo nascimento acontece também na vida real; é quando nasce meu segundo filho, Jahmall. A escrita de Alice foi a representação do que constelei psiquicamente nesse conto - o encontro com o "par perfeito"; o casamento, um novo nascimento e a morte que está por vir, a separação. Processos que se davam do lado de fora, mas que só aparecem em Alice porque, internamente, eu passava por esse processo de busca pelo self perdido, pelo self selvagem.

\section{5 - O quinto estágio - o tormento da alma}

Neste estágio de busca pelo self, Estés nos fala sobre “o tormento da alma”, o momento em que a mulher da estória estará mais uma vez sozinha e passará por grandes provas. Neste momento, pode haver nascimentos do plano real ou inconsciente, o que simboliza o renascimento interno, um novo self selvagem infantil.

No conto da donzela, logo depois do casamento, o rei parte para lutar em um reino distante. Há o nascimento do filho 
do casal e a mãe do rei fica responsável por cuidar da donzela e de seu bebê. Também é de sua responsabilidade avisar o rei sobre o nascimento dessa criança e, entre idas e vindas do mensageiro, há a intercepção do diabo, que arma diversas situações na tentativa de que o rei abandone a donzela ou de que ela morra. O afastamento do homem que acabou de se casar é bastante comum em contos de fadas. Estés explica que

“A razão é diferente em cada história, mas o fato psíquico essencial é o mesmo: a régia energia da psique recua e se afasta para que possa ocorrer o próximo passo no processo da mulher, e para que seja posta à prova sua postura psíquica recémadquirida. No caso do rei, ele não abandonou" (p.319).

O mesmo acontece na estória de Alice. No conto "Alice e os guerreiros de Aruanda" há o encontro e o convite para que Alice estabeleça parceria com o guerreiro, que no conto seguinte, "Alice na batalha final", se afasta para caçar, deixando Alice sozinha com Desejo e Presente. Não há abandono.

Alice mais uma vez se encontra entretida com seus afazeres cotidianos. Ela não está perambulando ou buscando por nada, está confortável na vida recém-construída. Mais um momento de conforto, estagnação, onde não há descidas ou inquietações. Ela se sente segura à espera do seu companheiro.

No entanto, o inesperado acontece. Alice se vê em meio a chamas e destruição. Há um ataque em seu acampamento e Alice se sente perdida e despreparada. Ela está só com um bebê e Presente, um jovem que ainda não se fez guerreiro. Alice precisa fazer algo antes que perca tudo e, nesse momento, não pode contar com seu guerreiro.

"Quando o rei vai embora em alguma aventura, sua contribuição psíquica para a descida é mantida pelo amor e pela memória (...) A donzela compreende que o princípio régio do outro mundo está 
comprometido com ela e não a abandonará, como prometeu antes de se casar" (p.320).

Sobre o conto da donzela, Estés trabalha sobre a representação simbólica da gravidez da donzela, do esperar, do nutrir, do nascimento de uma nova vida, que representa um self que está por vir. Alice não fica grávida, não é dito no conto que Desejo é filho do guerreiro e Alice, mas ele é um bebê, a representação de uma nova vida que surge para acompanhá-la. Assim como Presente, Desejo tem essa origem misteriosa das crianças divinas, que aparecem nos contos como milagres. São crianças abandonadas, encontradas, ou que simplesmente passam a existir onde não existiam antes. Considerei que Desejo possa simbolizar o prenúncio de um novo self infantil que está para surgir no mundo real.

Estés também cita um passo importante nesse estágio, que, simbolicamente, se deu em um processo muito diferente na estória de Alice: o encontro com a velha mãe selvagem, que no conto da Donzela é representada pela figura da mãe do rei (p. 321). No entanto em Alice não há algo que estabeleça essa relação de maneira tão explicita.

No momento em que o acampamento sofre o ataque e Alice se vê na condição de única responsável por salvar tudo que havia conquistado, ela entra em desespero e tenta fazer tudo que pode para salvar o que lhe é mais importante: Desejo e Presente. Que pode representar o próprio desejo em se manter viva e o tempo-presente, no qual se sente confortável pelas conquistas alcançadas. No entanto, é preciso renascer.

"A verdade nua e crua é que aquelas forças sagradas que encontramos dentro da nossa psique devem um dia ser abandonadas, pelo menos momentaneamente, para que o 
próximo estágio do processo possa se realizar. Nós devemos nos despedir das preciosas forças interiores que nos ajudaram imensamente" (p. 329-330).

Alice, sem domínio de suas asas, não consegue manter Desejo e Presente a salvos, perde-os e, agora, esta efetivamente sozinha. Alice sente raiva, tristeza e fúria e parte em direção à origem de tamanha destruição. A surpresa de Alice foi encontrar o dragão, que em sua estória, possui um caráter dual de mãe selvagem destruidora/protetora e que seria análogo ao conto da donzela, porém, reunidos em um único ser. Não há um diabo e uma rainha, há um dragão que carrega o simbolismo destas duas representações:

"Esse é o modelo arquetípico de descida desde o início dos tempos, e nós também seguimos esse sistema imemorial. Da mesma forma, temos uma sequência de missões terríveis atrás de nós. Vimos a respiração fumegante da Morte. Somos heroínas psíquicas com uma valise cheia de medalhas (...) processo sagrado não está esquecido, é só... que queríamos dar um tempo, só um pouquinho, fechar os olhos só por um instante... O diabo representa a irritação psíquica que nos atormenta com seu deboche:"Você voltou à sua antiga inocência e ingenuidade agora que se sente amada? Agora que deu à luz? Você acha que tudo está acabado, sua boba?' E, como estamos perto do Letes, continuamos a roncar. É esse o erro que todas nós cometemos não uma vez, mas muitas vezes. Nós nos esquecemos de nos lembrar do diabo" (p. 322).

Em outro trecho sobre a aparição do diabo nesse momento da estória, Estés afirma

"Aqui, o predador tem esperanças de que a psique se torne polarizada e se suicide ao rejeitar todo um aspecto de si mesma, aquele aspecto crucial, o recentemente desperto, o conhecimento da mulher. Esse é um senhor demônio e, no entanto, o que ele exige nos causa uma imensa hesitação. Ele quer que a donzela obedeça aos seguintes princípios: 'Não veja a vida como ela é. Não compreenda os ciclos da vida e da morte. Não persiga seus anseios. Não fale de todas essas coisas selvagens"' (p. 327).

Acho importante fazer uma ressalva neste ponto. A autobiografia foi finalizada junto com os contos de Alice em um 
momento em que ainda estava casada. Quando me separei poucos meses depois, senti a necessidade de escrever o conto "Alice e a batalha final", pois havia em mim um descontentamento com o final da estória de Alice, como se algo faltasse ali, algo que fosse extremamente importante para entender quem efetivamente simbolizava Alice nessa jornada de busca pelo meu self selvagem.

Durante a separação, decidimos, eu e Pedro, que deveríamos tentar reatar a relação e, em mim, havia uma certeza de que para permanecer neste casamento eu deveria me transformar em algo que não sou - o que é curioso - porque o objetivo desta jornada pela busca do self, era me reencontrar com algo que estava perdido em mim. Como resultado deste "permanecer" na relação, buscando ser outra pessoa, escrevi um conto final em que Alice morria fragmentada como cacos de vidro. Seria então a aceitação de que eu não iria assumir meu verdadeiro self. Porém, esse conto proporcionou um insight profundamente importante sobre Alice. Percebi que Alice fora durante todo o tempo uma personagem muito passiva.

Alice passa por inúmeras provas e desventuras. São poucos os momentos em que está feliz e realizada e, em todos os momentos de dificuldade, Alice apenas reage superando o obstáculo, como se nada pudesse ativar sua força maior. Faltava algo em Alice. Faltava fogo. Alice, que sempre buscara pela luz, nunca deixou transparecer a sua chama interior. Faltava a alma selvagem.

Por fim, achei muito cruel e injusto, terminar a estória de Alice com sua própria morte. Assim reescrevi o conto "Alice e a batalha final", no qual, Alice por meio da fúria busca sua força 
maior, uma força que nunca havia acessado e que dá controle sobre suas asas, a ponto de enfrentar a descida para dentro do dragão.

Essa ascensão de Alice pelas suas próprias asas e a descida para o coração do dragão já são momentos de transição entre o quinto e sexto estágio da busca pelo self.

\section{6 - O sexto estágio - o reino da mulher selvagem}

No sexto estágio de busca pelo self, Estés nos fala sobre "O reino da mulher selvagem”. É um estágio de conclusão, no qual a mulher é conduzida pela velha “mãe selvagem" ao campo iniciático, onde resgatará os ensinamentos obtidos ao longo da jornada para sua regeneração e aprendizado. É a busca pelo "santo corpo inteiro" (p. 333), que Estés explica como quando

"ela conseguiu captar, com prática e profundidade, o nãoconcreto, o metafórico, o caminho sagrado em que esteve. À medida que praticamos o profundo conhecimento instintivo acerca de todo tipo de aprendizado que obtemos durante toda uma vida, nossas mãos voltam a nós, as mãos da nossa feminilidade” (p. 334).

Durante a análise da estória de Alice não reconheci esta passagem. A regeneração se dá a partir da reconstituição do membro mutilado no segundo momento da busca pelo self, que eu identifiquei na cicatriz deixada na mão de Alice. No entanto, houve uma regeneração: Alice conquista o domínio sobre suas asas. Essa deve ter sido a mutilação causada no corpo da Alice em consequência do "pacto infeliz" e não a cicatriz em sua mão.

A principal característica física e dominante em um ser alado são suas asas. De que adiantariam asas sem a possibilidade 
da escolha do momento do voo? Em um ser humano, os membros análogos às asas, são as mãos. Porém, Alice não é humana. Alice seria, por natureza, borboleta, representação simbólica da alma, no sentido de vida (Cirlot, 1971). Alice é um self com a alma mutilada, nasce sem poder sobre seu dom principal, o de voar, transcender. Ao regenerar suas asas a partir da manifestação de sentimentos, que até então nunca haviam sido manifestados, Alice readquire o poder sobre si mesma.

Antes de entrar pelas ventas do dragão, Alice passa pelo fogo e pelo calor; é a representação da vida que volta a pulsar em Alice. A descida para o campo iniciático mais profundo é a chegada ao coração do dragão. Alice está no interior mais profundo de si mesma.

No coração do dragão, Alice esculpe sua própria imagem. Nesse episódio há ressonâncias com Frida Kahlo e sua obra. Por que pintar a si? Por que Alice esculpe sua imagem no coração do Dragão até matá-lo? Levinson (2007, p. 58), que investigou sobre a obra da artista, explica que

"Frida criava por meio de seus autorretratos um espelho próprio, um olhar que tinha a função de autossustentação e reconhecimento de si mesma (...) Tentava com isso restaurar a imagem de si mesma, que mais parecia um espelho quebrado, e construía a ilusão de que podia se converter no espelho materno que nunca teve."

Para encontrar seu self selvagem, Alice precisava se enxergar, reconstituir a imagem que tinha de si por meio de seu próprio trabalho, com suas próprias mãos, e o fez entalhando o coração do dragão, que morreu diante de tantos cortes em seu coração. A verdadeira Alice estava abaixo de muitas camadas no coração do dragão. "O herói é o patrono das coisas que se estão tornando e não das coisas que se tornaram, pois ele é. (...) 
Assim, se permite que o momento seguinte venha a ocorrer" (Campbell, 1997, p. 236).

Alice cava um túnel e renasce, pronta para reencontrar o que foi perdido em sua jornada. "É aí que a mulher sente que afinal conseguiu retomar o controle sobre a própria vida $e$ recuperar as palmas que a ajudam a ver e a moldar a vida novamente. Agora, ela está realmente 'dentro do seu Self". (Estés, 1999, p. 335)

\section{7 - O sétimo estágio - o noivo e a noiva selvagens}

No estágio final de encontro com o self, Estés afirma que "o noivo e a noiva selvagens", por fim se encontram para juntos poderem formar o novo self, que se caracteriza pela união dos mundos objetivo e subterrâneo.

Nesse estágio, a donzela do conto estudado por Estés se reencontra com o rei que passou sete anos perambulando pela floresta em uma luta com outros reinos. Esta perambulação deu ao rei a aparência suja, descuidada, maltrapilha, como a que passou a donzela no inicio de sua perambulação. O rei está pronto para se recompor e acompanhar sua donzela em uma união definitiva.

Esta passagem não se vê em Alice. Não houve retorno do guerreiro. O rei-guerreiro representa o animus, "representa a adaptação da mulher à vida coletiva - ele transporta as idéias principais que ela aprendeu na sua jornada até a superfície, ou a sociedade exterior.” (Estés, 1999, p. 335) 
A busca de Alice não chegou ao fim. Alice precisa resgatar o masculino perdido na última batalha. Porém, Alice resgatou sua alma, sua essência feminina, seu dom de voar.

"Quando emergimos de volta do outro mundo depois de uma das nossas incursões por lá, por fora pode parecer que não mudamos, mas por dentro reconquistamos um vasto território feminino e selvagem. Na superfície, ainda somos simpáticas, mas debaixo da pele decididamente não somos mais mansas" (p. 338). 


\section{4 - Deixa “serei-ar"...}

Escrever esta tese foi uma das experiências mais incríveis da minha vida, enquanto experiência de escrita, estudos, aprofundamentos teóricos, descobertas, vivências, contato com a vida da maneira em que ela estava em mim. Estava em mim, porque foi profunda a consciência de que tudo que coloquei no papel, foi o que me permiti reviver em memória a partir do que o vivido reverberava no momento da escrita. Hoje, se fosse reescrever, seriam outras palavras, outros momentos, outras leituras.

A vida é assim, vai em onda e vem em mar. Não se tem controle daquilo que virá, nem mesmo se o que estiver por vir já tiver vindo antes. Tudo muda... as pessoas, os olhares, os caminhares, os sentires. Os sentidos das coisas mudam à medida que mudamos com tudo que passa.

A escrita autobiográfica me permitiu organizar em uma linha cronológica "mais ou menos" coerente, os fatos da vida. Essa medida de ser mais ou de ser menos fica evidente no implícito da subjetividade da própria escrita. Nem tudo foi dito nos tempos que se sucederam, nem tudo foi lembrado e, do que foi lembrado hoje mesmo, já poderia ser dado de outra forma... Parece vago, porque é mesmo do vaguear... do vadiar, do entregar-se ao momento.

Pude colocar no papel sensações, cheiros, nomes, lembranças, sentimentos. Pude entender um pouco sobre como fui levada pela vida, sobre os momentos em que precisei pegá-la com as mãos e fazer dela algo melhor e dos momentos em que 
nada pude fazer, além de vivê-la da maneira como me era dada. Ah! Esta vida traiçoeira parece que vai e não vai, parece que brilha e apaga, parece que é minha e, logo mais, não parece ser de ninguém.

Em muitos momentos a escrita parou. Ficou difícil. Tive pausas imensas durante a produção. Era preciso me afastar de mim. Houve muita dor no resgate de algumas memórias. Dores que eu nem sabia que existiam, mas que estavam em mim junto com as marcas de quem sou. E as marcas? Fui dando nome para cada uma delas. O corpo virou álbum de retratos. Fui notando cada pedacinho de mim sendo construído ao longo de um tempo irreal. Fui nomeando um andar, identificando uma busca, compreendendo o jeito de amar, amando o jeito de aprender. Fui me notando enquanto ser em construção. Assim como a vida, eu também vou em ondas. Eu também não vou sólida, vou líquida no contorno das pedras que vão se colocando no caminho. No caminho que antes de ser mar era rio, mas que depois, virou rochedo. Paredão que barra o mar na bem-aventurança de sua procura pela terra.

Eu dei para "serei-ar". Estava tão mergulhada nas profundezas de angústias e inquietações, minha alma estava tão afogada em mim, que já nem podia respirar. A escrita veio me ajudar a "serei-ar", a buscar o ar num respiro profundo e poético, como das sereias que saem das profundezas do oceano para virem cantar a sedução aos homens do mar. Mais que sedução, nesta tese fica explícito o potencial de empoderamento que há para a pessoa da mulher na reapropriação das suas próprias narrativas de vida (num mundo patriarcal), dialogando com as imagens profundas da ancestralidade afro-ameríndia (num 
mundo ocidental) e com a reconexão com a natureza (num mundo capitalista) e sua própria natureza selvagem como vimos nestas perspectivas de ambientalismo. Neste sentido, a tese também se articula às investigações de pesquisadoras que vêm progressivamente demarcando a necessidade desta reapropriação de sua voz em suas narrativas de vida (Oliveira, 2008; Vale, 2012; Willms, 2013; Rubira, 2015; Fonseca, 2016), politicamente em poesia.

A poesia veio em Alice. Até hoje não sei quem é Alice. Se é loba, se é gente, se é bruxa, se é fada, se é branca, se é negra. Não sei o tamanho de suas asas, e penso até que Alice poderia ser uma sereia do ar. Dessas que num voo profundo descobrem que podem ir até bem mais longe, mergulhando no profundo do mar. Esses movimentos bachelardianos dos elementos que nos constituem, eu-ar, eu-terra, eu-água, eu-fogo, eu-sonho. Alice foi quase todos, agora no final da escrita foi que tudo desaguou no mar. Um movimento que, em si, já daria um novo estudo. Tanta água Alice liberou nesse movimento de buscar pelo ar.

Durante o processo da escrita de Alice, fui dando nomes de personagens ficcionais para cada ser-gente que havia deixado um pouco de si em mim. Foi catarse. Poder dar nome de monstro, princesa ou dragão para cada sentimento que aflorava em mim. Foi também imensa ingenuidade. Tive o cuidado de não ler nada sobre construção simbólica durante a elaboração das Alices. Não queria ser influenciada na criação das imagens. Queria ser fiel, concreta, real. Fui honesta, apenas honesta. Esse fiel, concreto e real não cabe no campo do imaginário e, nas análises, fui descobrindo o que estava escondido no subterrâneo de mim. 
Alice me levou para uma jornada fantástica de descobertas sobre um eu que estava atolado, enlameado, sujo e escamoteado. Alice, com toda sua doçura, me levou para as profundezas do imaginado em mim. Disse-me em bom tom e de forma muito cuidadosa que aquela gente toda que andou com ela não era aquela gente que andou comigo pela vida; era só eu mesma. Alice foi me revelando em cartas de tarô. Sem nenhuma pretensão de adivinhar destinos, Alice foi cuidando do presente, me fazendo achar que eu estava mexendo no passado.

Essas gentes que andaram com ela, eram fragmentos do eu do agora que sequer conseguiam se encontrar. Vivia num mar de mundo, montes de eu se buscando, tentando se decifrar. Eu, que só via de longe tamanho caos de imagens, não entendia que era tudo peça de um quebra-cabeça só. Peça da cabeça, só. Peçacabeça. Peça-eu. Eu, numa cabeça em um monte de peças.

Alice veio, mostrou, organizou e revelou a imagem que era uma.

E quanto aos mestres? Desses nem sei o que dizer. Foram muitos os mestres. Eu, na tese, menciono dois; os dois guias que me levam para mundos muito distintos, porém complementares. Um foi mestre da ida, outro foi mestre do retorno. Em sua maestria, me ensinaram a pôr os pés no chão, andar com mais cautela, não me esquecer de quem sou e dançar; dançar ao som da música que sempre toca no tambor que está dentro. Todos nós temos do lado de dentro um tambor que toca para que não nos esqueçamos que a vida vem em melodia. Quando ele pára, a vida acabou.

Mas tiveram outros mestres. Muitos mestres... Muitos homens e mulheres que passaram em minha vida e que deles 
esperei resposta. Nenhum deles me respondeu. Eu ficava aflita, chorava, gritava, mas o silêncio era definitivo. Assim, descobri que o silêncio também é mestre. Quem não tem resposta fica em silêncio, o dono da pergunta que converse com o silencio e chegue sozinho onde quer chegar. Alice assim me ensinou.

Os contos de Alice foram muito pobres de mulheres. Alice quase nunca anda acompanhada do feminino. O feminino andava pobre em mim. Foi preciso que Alice viesse me dizer que estava cheia de fome de útero, cheia de fome do vermelho vivo das entranhas que tem o destino de parir. Alice veio me pedir para chamar sua alcateia de lobas selvagens, que andavam aprisionadas em jaulas na selva dentro de mim. Alice disse da nossa Baba Yaga, da nossa velha anciã que trancada em seu casebre, quase morreu sedenta por ser ouvida.

Alice veio me dizer da minha loba que morria lentamente de fome, sede, amor e atenção. Alice me falou das outras lobas e das outras mulheres selvagens que clamavam para que eu voltasse. Alice veio me dizer da mulher, da que havia em mim e das outras que estão no mundo e vivem solitárias em busca de irmãs em que possam se apoiar. Alice me disse que seria preciso me resgatar para que eu pudesse enxergar estas outras mulheres que também vivem sedentas e famintas, porque o mundo não permite o feminino - o sagrado fértil da terra, onde se cria e gera o novo.

Alice, que nem era de sangue ou dada às armas de corte, teve que, ela própria, enfrentar o dragão. Alice foi guerreira. Entrou no mais fundo daquilo que me atormentava e me fez verme neste lugar. Alice nos reconectou. 
Alice foi em direção ao Sol que se põem, esse Sol crepuscular que anuncia a chegada da noite. Mas antes de partir, Alice deixou claro:

- Segue teu caminho e cuida de ti. Você agora já sabe, que és tu mesma, a mestra de ti.

Boa sorte, Alice! Foi um prazer te acompanhar nesta jornada. 


\section{Referências bibliográficas}

Abril Cultural. Dicionário de Mitologia Greco-Romana. São Paulo: Editora Victor Civita, 1973.

ARAÚJO. Rosângela Costa. ÎE, VIVA MEU MESTRE. A Capoeira Angola da 'escola pastiniana' como práxis educativa. São Paulo: FEUSP, tese de doutorado, 2004.

BACHELARD, Gaston. Formação do Espírito Científico. Rio de Janeiro: Contraponto, 1996.

Martins Fontes, 1998.

A água e os sonhos. São Paulo:

Martins Fontes, 2001.

O ar e os sonhos. São Paulo:

A poética do Devaneio. São

Paulo: Martins Fontes, 2009.

BARBOSA, Teresa V. Representações do feminino no drama satírico: as ninfas, amenas e sombras. Humanitas. Vol. 60, 2008.

BERKENBROCK-ROSITO, Margaréte May. Educação Estética: Histórias e Vivências da Docência. Cultura Escolar Migrações e Cidadania. Actas do VII Congresso USOBRASILEIRO de História da Educação. Porto: Faculdade de Psicologia e Ciências da Educação (Universidade do Porto), Junho, 2008.

CAMPBELL, Joseph. O herói de mil faces. São Paulo: Cultrix/Pensamento, 1997.

O poder do mito. São Paulo: Palas

Athena, 2012. 
CAPUTO, Stella G. Educação nos Terreiros e como a escola se relaciona com crianças de candomblé. Rio de Janeiro: Pallas, 2012.

CARVALHO, Siberia Regina. O ensino-aprendizagem da autobiografia: Uma possibilidade para o desenvolvimento da linguagem escrita. Tese de doutorado em linguística aplicada e estudos da linguagem. São Paulo: Pontifícia Universidade Católica de São Paulo, 2011

CHEVAlIER, Jean; GHEERBRANT, Alain. Dicionário de Símbolos. Rio de Janeiro: José Olympo, 2005.

CIRLOT, Juan. Dictionary of symbols. London: Routledge, 1971.

COHEN, Jeffrey Jerome. A cultura dos monstros: sete teses. In: SILVA, Tomaz Tadeu da (Org.). Pedagogia dos monstros: os prazeres e os perigos da confusão de fronteiras. Belo Horizonte: Autêntica, p. 23-60, 2000.

CORREIA, Rita M. O arquétipo da Princesa na Costrução social da feminilidade. Universidade Nova de Lisboa, Faculdade de Ciências Sociais e Humanas, Dissertação de mestrado, 2010.

DELL, Chistopher. Mitologia- Um guia dos mundos imaginários. São Paulo: Edições SESC, 2014.

DURAND, Gilbert. Campos do imaginário. Lisboa: Instituto Piaget, 1998.

Imaginário. São Paulo: Wmf Martins Fontes, 2012.

ESTÉS, Clarissa Pinkola. Mulheres que correm com lobos. Rio de Janeiro: Rocco, 1999. 
FERREIRA, Agripina E. A. Dicionário de imagens, símbolos, mitos, termos e conceitos Bachelardianos. Editora da Universidade Estadual de Londrina. Londrina/PR. 2013

FERREIRA-SANTOS, Marcos. A Educação Brasileira na Primeira República: O "Doutor" Positivista. São Paulo: Faculdade Marcelo Tupinambá, 1993.

. "Ancestralidade e Convivência no Processo Identitário: a dor do espinho e a arte da paixão entre Karabá e Kiriku”. In: Educação Anti-Racista: Caminhos Abertos pela Lei Federal $N^{\circ}$ 10.639/03. Secretaria de Educação Continuada, Alfabetização e Diversidade. Brasília: Ministério da Educação, SECAD, 2005 a.

Crepusculário: conferências sobre mitohermenêutica \& educação em Euskadi. São Paulo: Editora Zouk, 2a. ed., 2005b.

Oikós: topofilia, ancestralidade e ecossistema arquetípico. Anais do XIV Ciclo de Estudos sobre o Imaginário - Congresso Internacional: As dimensões imaginárias da natureza. Recife: UFPE/Associação Ylê Setí, p. 41-71, 2006. Disponível em: http://www.univmontp3.fr/ufr5/irsa/telechargements/XIV Ciclo_De_Estudos Sobre O Imaginario ANAIS.pdf

alunos. São Paulo: Feusp Pensa, n.o 3, 3.o trimestre, 2007.

Lab_arte: uma conquista dos . Espaços crepusculares: poesia, mitohermenêutica e educação de sensibilidade. Revista @mbienteeducação, v. 1, n. 1, Jan/Julho 2008. Disponível em: http://www.cida- desp.edu.br/old/revista_educacao/index.html. Acesso em: 27/08/2014 
. Fundamentos antropológicos da

arte-educação: por um pharmakon na didaskalia. Revista @mbienteeducação, São Paulo, v. 3, n. 2, p. 59-97, jul./dez. 2010b.

. Matrices de la persona afro-ameríndia: escritura como obra de vida. In: Flórez, C.M. (org.) Urdimbres. Cali: Editorial Buenaventurriana, Universidad de San Buenaventura Cali, pp. 219-248, 2010 .

\section{Cultura Imaterial e processos}

simbólicos. Rev. do Museu de Arqueologia e Etnologia, São Paulo, 14: 139-151, 2004

\section{O ancestral: entre o}

singular e o universal. In: AMARAL, M. \& CARRIL, L. O hip hop e as diásporas africanas na modernidade - uma discussão contemporânea sobre cultura e educação. São Paulo: Alameda, p. 193-233, 2015.

Innovación curricular y enseñanza superior: el arquetipo del maestro-aprendiz en la experiencia de lab_arte. In: VII Cátedra Agustín Nieto Caballero: Practicas innovadoras y reflexivas en educación superior. Bogotá: Universidad Pedagógica Nacional, p. 67-74, 2012b.

FERREIRA-SANTOS, Marcos; ALMEIDA, Rogério de. Aproximações ao imaginário: bússola de investigação poética. São Paulo: Képos, 2012.

FERREIRA-SANTOS, M.; MORALES, Patrícia Perez \& RUBIRA, Fabiana. Aproximaciones a la educación sensible: vivencia en los núcleos experienciales en Astronomía y Arte-educación. Bogotá: IDARTES - Planetario de Bogotá, 2014. 
FONSECA, Elisabete Martins. Imaginário e Formação de Educadores: a narrativa de si. São Paulo: FEUSP, tese de doutoramento, 2016.

FREYRE, Gilberto. Casa Grande e Senzala. São Paulo: Global Editora, 2006.

FURLANI, Jimena. Sexos, sexualidades e gêneros: monstruosidades no currículo da Educação Sexual. Educ. rev., Belo Horizonte, n. 46, p. 269-285, Dec. 2007 . Available from <http://www.scielo.br/scielo.php?script=sci_arttext\&pid=So10 2-46982007000200011\&lng=en\&nrm=iso $>$. access on 13 July 2016. http://dx.doi.org/10.1590/S0102-46982007000200011.

FREITAS, Alexander de. Apolo-Prometeu e Dioniso: dois perfis mitológicos do "homem das 24 horas" de Gaston Bachelard. Educ. Pesqui., São Paulo , v. 32, n. 1, p. 103-116, Apr. 2006 . Available from <http://www.scielo.br/scielo.php? script=sci_arttext\&pid=S1517-97022006000100007\&lng=en\& n rm=iso $>$.access on 13 July 2016. http://dx.doi.org/10.1590 /S1 517-970 22006000100007.

GALLE, Helmut Paul Erich. Elementos para uma nova abordagem da escritura autobiográfica. Matraga (Rio de Janeiro), v. 18, p. 64-91, 2006.

GALVANI, Pascal. A Autoformaçao, uma perspectiva transpessoal, transdisciplinar e transcultural. In: Educação e Transdisciplinaridade II. São Paulo: Triom, 2002.

GINZBURG, J. Impacto da violência e constituição do sujeito: um problema da teoria da autobiografia. In: IZARRA, L. (Org.). Em primeira pessoa: abordagem de uma teoria da autobiografia. São Paulo: Annablume, p. 123-139, 2009.

GOMES, Fabio José Cardias. O pulo do gato preto: estudo de três dimensões educacionais das artes-caminhos marciais em uma linhagem de capoeira angola. São Paulo: FEUSP, tese de doutorado, 2012. 
GUSDORF, Georges. Professores para quê?. São Paulo: Martins Fontes, 2003.

HAMPATE-BÁ, Amandou. A tradição viva. In: Ki-Zerbo, J. (Ed.). História geral da África - vol. I: Metodologia e préhistória da África. Brasília: UNESCO, 2a. ed. rev., pp.167-212, 2010.

HARPER, B., CECCON, C, OLIVEIRA, M. OLIVEIRA, R. Cuidado, Escola! São Paulo: Brasiliense, 1991.

HENDERSON, J. L. A Bela e a Fera. In: JUNG, G. C (Ed.) o homem e seus símbolos. Rio de Janeiro: Nova Fronteira, 2002.

JOSSO, M. Christine. Experiências de vida e formação. Lisboa: Editora Educa-Formação/Universidade de Lisboa, 2002.

A transformação de si a partir da narração de histórias de vida. Porto Alegre/RS, Educação. $n$. 3 (63), p. 413-438, set./dez., 2007.

JUNG, C.G. Os arquétipos e o inconsciente coletivo. Petrópolis: Editora Vozes, 2002a

Janeiro: Nova Fronteira, 2002b.

O homem e seus símbolos. Rio de Simbolos de Transformacion. Buenos Aires: Editorial Paidos, 1962.

A psicologia do arquétipo da criança In: Jung, C. G e Kérenyi, K. A criança Divina - Uma introdução à essência da mitologia. Petrópolis: Editora Vozes, 2011.

JUNG, C. G e Kérenyi, K. A criança Divina - Uma introdução à essência da mitologia. Petrópolis: Editora Vozes, 2011. 
KÉRENYI, Karl. A criança original In: Jung, C. G e Kérenyi. A criança Divina - Uma introdução à essência da mitologia. Petrópolis: Editora Vozes, 2011.

LE GOFF, Jacques. O maravilhoso e o quotidiano no ocidente medieval. Lisboa: Edições 70, 1990.

LEVINSON, Gina K. Frida Kahlo: a pintura como processo de busca de si mesmo. Revista Brasileira de Psicanálise, Volume 43, n. 2, 49-60, 2009.

MATHEUS, C. E.; MORAES, A. J. de; CAFFAGNI, C. W. do A. Educação ambiental para o turismo sustentável: vivências integradas e outras estratégias metodológicas. São Carlos: Rima, 2005.

OLIVEIRA, Kiusam de. Candomblé de Ketu e Educação: Estratégias para o Empoderamento da Mulher Negra. São Paulo: FEUSP, tese de doutoramento, 2008. Disponível em: http://www.teses.usp.br/teses/disponiveis/48/48134/tde16062008161253/publico/Kiusam Regina de Oliveira tese.pdf

PAULA CARVALHO, José Carlos. A problemática da construção dos personagens e as figuras mítico-imaginais. In: Imaginário e mitodologia: hermenêutica dos símbolos e estórias de vida. Londrina: Ed. UEL, p.225-249, 1998.

PEREIRA, E. A. Os tambores estão frios: herança cultural e sincretismo religioso no ritual de Candombe. Belo Horizonte: Mazza Edições; Juiz de Fora: Funalfa Edições, 2005

PINEAU, Gaston. A autoformação no decurso da vida: entre hetero e a ecoformação. In: NÓVOA, António; FINGER, Matthias (Org.). $O$ método (auto)biográfico e a formação. Lisboa: Ministério da Saúde, p. 65-77, 1988.

RICOEUR, P. Percurso do reconhecimento. São Paulo: Loyola, 2006. 
ROSA. José M. da S. Da Identidade Narrativa - Paul Ricoeur, leitor de Santo Agostinho. Lisboa: Universidade Católica Editora, pp. 557-597, 2003.

ROSITO, Margarete e SAGGESE, Regina. Pedagogia imaginal e processos formativos: arte, narrativas e mitos. Educação \& Linguagem, v. 13, n. 22, 132-152, jul.-dez., 2010.

Colcha de Retalhos: história de vida

e imaginário na formação. Educação Santa Maria, v. 34, n. 3, p. 487-500, set./dez. 2009.

RUBIRA, Fabiana de Pontes. Dançando com o Minotauro nas Noites - Narração de Estórias e Formação Humana. São Paulo: FEUSP, Tese de Doutorado, 2015.

SARTRE, J. P. Esboço para uma teoria das emoções. Porto Alegre: L\&PM, 2008.

THOMPSON, P. História oral: patrimônio do passado e espírito do futuro. In: WORCMAN, K.; PEREIRA, J. V. (coords). História falada: memória, rede e mudança social. São Paulo: SESC São Paulo; Museu da Pessoa: Imprensa Oficial do Estado de São Paulo, 2006.

TUAN, Yi-Fu. Topofilia: um estudo da percepção, atitudes e valores do meio ambiente. São Paulo: Editora Difel, 1974.

TRINDADE, Nancy. A Bruxa nos contos de Fadas. São Paulo: Universidade Presbiteriana Mackenzie, Dissertação de mestrado, 2008.

VALE, Elis Regina Feitosa do (2012). Capoeranças em verso e prosa: imagens da força matrial afro-ameríndia em literaturas da capoeira angola. São Paulo: FEUSP, dissertação de mestrado, 2012.

VALENTE, W. Sincretismo Religioso Afro-Brasileiro. São Paulo: Companhia Editora Nacional, $3^{\text {a }}$ ed., 1977. 
WILLMS, E.E. Escrevivendo: Uma Fenomenologia

Rosiana do Brincar. São Paulo: FEUSP, Tese de Doutorado, 2013 .

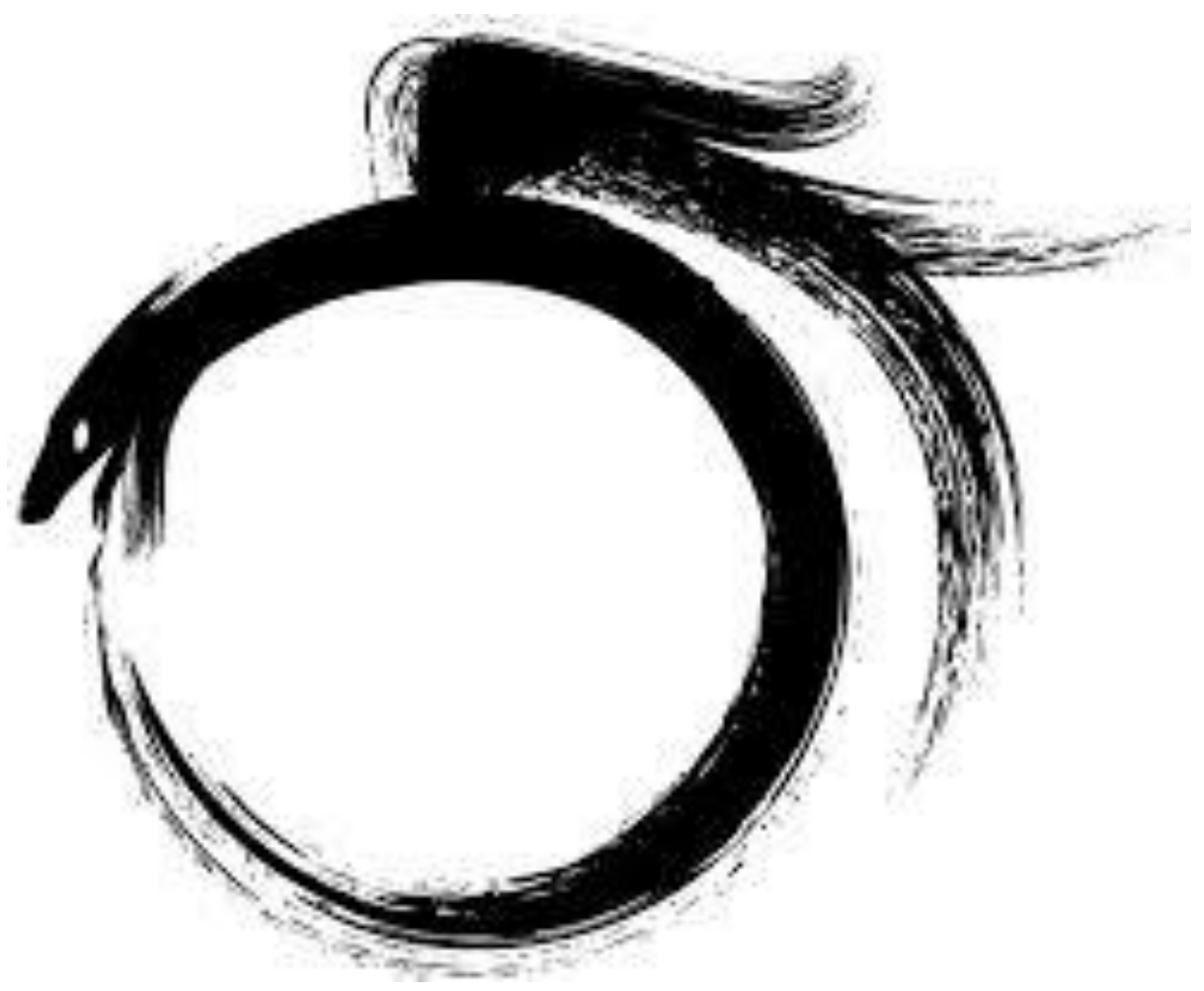

